\title{
toen
}

INSTITUTO DE PESQUISAS ENERGÉTICAS E NUCLEARES

Autarquia associada à Universidade de São Paulo

\section{CONTAMINAÇÃO DO SOLO E MOBILIDADE DE As, Cd, Mo, Pb e Zn EM COLUNAS DE SOLO FRANCO ARENOSO COM CINZA DE CARVÃO}

\section{CAMILA NEVES LANGE}

Dissertação apresentada como parte dos requisitos para obtenção do Grau de Mestre em Ciências na Área de Tecnologia Nuclear - Materiais.

Orientadora:

Dra. lara Maria Carneiro de Camargo 
Ao meu marido lgor, por ser meu grande incentivador e à minha filha Lena, nascida durante 0 mestrado. 


\section{AGRADECIMENTOS}

À Deus, por mais essa conquista e por tantas outras até chegar aqui.

À Dra. lara Maria Carneiro de Camargo pela oportunidade, incentivo, amizade e acima de tudo pela compreensão durante o período da licença maternidade.

À Dra. Maria Eugênia Gimenez Boscov pelas diversas contribuições ao longo da realização desse trabalho.

Ao IPEN/CNEN-SP e ao Centro de Química e Meio Ambiente, CQMA, pela infraestrutura.

À CNEN pela bolsa de mestrado concedida.

À FAPESP pelo auxílio financeiro ao projeto de pesquisa.

À Dra. Denise Fungaro e à Dra. Nilce Ortiz por dividirem o espaço no laboratório.

Ao Dr. Reginaldo Bertolo pelos ensinamentos no PHREEQC.

À Dra. Marycel Cotrim, à Dra. Elizabeth Dantas e à Dra. Elaine Martins pela disponibilização dos laboratórios, análises e equipamentos.

Aos funcionários do CQMA por serem sempre solícitos e em especial à Lucilena Monteiro pelas análises, ensinamentos e amizade.

Às minhas colegas de orientação Juliana Silva, Flávia Junqueira e Cibele Bocci, pelo auxílio inegável a todo tempo.

Aos colegas de pós-graduação ou iniciação científica pelos bons momentos juntos.

Aos grandes amigos conquistados na pós-graduação: Renata Rodrigues, Renan Azevedo, Juliana Otomo e Daniele Xanchão, por toda cumplicidade, ajuda e amizade.

Aos meus pais, Rodolfo e Elaine, pelo exemplo, estímulo e amor incondicional.

Ao meu irmão Daniel pelo apoio sincero.

À minha irmã Tarcila, por me ouvir, por ser meu ombro amigo e minha conselheira.

Ao meu marido Igor, por ser mais que um companheiro, por ser meu anjo na Terra, sem seu apoio eu não teria coragem! 
À nossa filhinha Lena, por ficar tão boazinha na minha ausência e por ser essa luz em nossas vidas. 
"Sem sonhos, os monstros que nos assediam, estejam eles alojados em nossa mente ou no terreno social, nos controlarão. $O$ objetivo fundamental dos sonhos não é o sucesso, mas nos livrar do fantasma do conformismo. Lembre-se de que sonhos sem riscos produzem conquistas sem méritos". 


\title{
CONTAMINAÇÃo DO SOLO E MOBILIDADE DE As, Cd, Mo, Pb e Zn EM COLUNAS DE SOLO FRANCO ARENOSO COM CINZA DE CARVÃO
}

\author{
CAMILA NEVES LANGE \\ RESUMO
}

Elementos tóxicos podem provocar impacto na qualidade ambiental dos solos e representar risco à saúde humana. As cinzas leves de carvão são uma fonte de elementos tóxicos e são comumente dispostas de maneira inadequada sobre 0 solo nas proximidades das usinas termelétricas, onde esses elementos podem ser lixiviados pela chuva, transportados para as fontes de águas naturais e absorvidos pela fauna e flora do solo, podendo assim, entrar na cadeia alimentar humana. Neste estudo foi avaliada a mobilidade dos elementos As, Cd, Zn, Pb e Mo em colunas de solo franco arenoso com cinza de carvão da usina termelétrica de Figueira, Paraná. Para tanto, colunas de cinza de carvão, solo e solo coberto com cinza foram lixiviadas com uma solução ácida ao longo de 336 dias e as amostras de cinza, solo e percolado das colunas foram caracterizadas quanto à concentração dos elementos e propriedades físicas, químicas e mineralógicas. Os resultados obtidos mostraram que $\circ \mathrm{Pb}$ não foi lixiviado da cinza de carvão, indicando que a lixiviação de $\mathrm{Pb}$ da cinza de carvão não representa risco ambiental. O Cd foi o elemento mais retido pelo solo franco arenoso, seguido de As. O Mo foi lixiviado da cinza de carvão, mas não foi detectado no solo e nos percolados das colunas de solo+cinza. Nas condições de estudo, o Zn não representou risco ambiental. Observou-se também que a concentração de As no solo excedeu o valor de intervenção para área de proteção máxima estabelecido pela Companhia Ambiental do Estado de São Paulo (CETESB) e a concentração de $\mathrm{Cd}$ no solo excedeu o valor de qualidade de referência estabelecido pela mesma companhia ambiental. 


\title{
SOIL CONTAMINATION AND MOBILITY OF As, Cd, Mo, $\mathrm{Pb}$ and $\mathrm{Zn}$ IN SANDY LOAM SOIL COLUMNS WITH COAL FLY ASH
}

\author{
CAMILA NEVES LANGE
}

\begin{abstract}
Toxic elements can cause impact on soil environmental quality and represent risks to human life. Coal ashes, considered as a source of toxic elements, are commonly disposed inadequately on the soil surface around thermoelectric plants, from where these elements can be transported to natural water sources or to be absorbed by plants, soil fauna and flora and consequently impact on food chain. The aim of this study was to evaluate the contamination of a sandy loam soil and the mobility of $\mathrm{As}, \mathrm{Cd}, \mathrm{Mo} \mathrm{Pb}$ and $\mathrm{Zn}$ from coal fly ash of Figueira Power Plant. Experiments with columns of coal fly ash, soil and soil covered with ash were carried out to simulate contamination by acid leaching during 336 days and samples of ash, soil and leachate were characterized by the determination of elements concentration and chemical, mineralogical and physical properties. Results indicate that $\mathrm{Pb}$ was not was not released from fly ash on study conditions, providing evidence that $\mathrm{Pb}$ leaching does not pose a risk to the environment. Mo was leached from fly ash, but was not detected on soil and on leachate of soil+ash columns. In study conditions, $\mathrm{Zn}$ did not represent environmental concern. As exceeded the intervention value for maximum protection area established by the Environmental Protection Agency of the State of São Paulo (CETESB) and Cd did not exceed the quality reference value established by the same agency.
\end{abstract}




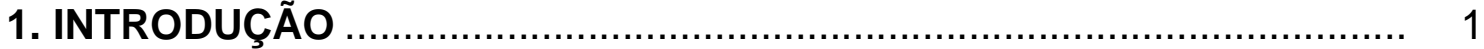

2. OBJETIVOS

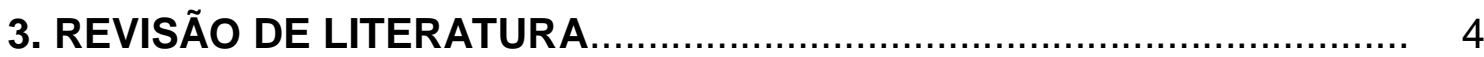

3.1. Componentes do solo........................................................ 4

3.1.1. A fase sólida do solo................................................. 5

3.1.1.1. Os constituintes inorgânicos do solo....................... 5

3.1.1.2. A matéria orgânica do solo ..................................... 8

3.1.2. A fase líquida do solo..................................................... 10

3.2. As cargas superficiais em solos.......................................... 11

3.3. A origem dos elementos tóxicos em solos .............................. 14

3.4. Propriedades dos solos e os principais processos de

interação entre os elementos e o solo ........................................... 16

3.4.1. pH do solo............................................................. 17

3.4.2. Matéria orgânica do solo e as reações de complexação...... 21

3.4.3. A fase sólida do solo e os processos de sorção ................. 22

3.5. Solos brasileiros ................................................................. 24

3.6. As cinzas de carvão oriundas em usinas termelétricas.............. 27

3.6.1. Cinzas de carvão - Panorama Mundial.............................. 27

3.6.2. Produção de cinzas no Brasil ….......................... 28

3.6.2.1. Tipos de cinzas geradas nas usinas termelétricas brasileiras................................................................ 29

3.6.2.2. Composição das cinzas de carvão brasileiras....... 30

3.7. Toxicidade dos elementos As, $\mathrm{Cd}$, Mo, $\mathrm{Pb}$ e $\mathrm{Zn}$........................ 32

3.8. Espécies químicas dos elementos $\mathrm{As}, \mathrm{Cd}$, Mo, $\mathrm{Pb}$ e $\mathrm{Zn}$ no solo 33

3.8.1. Arsênio....................................................................... 33

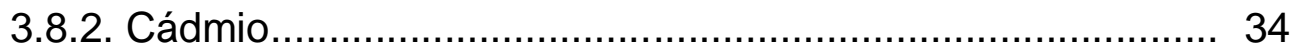

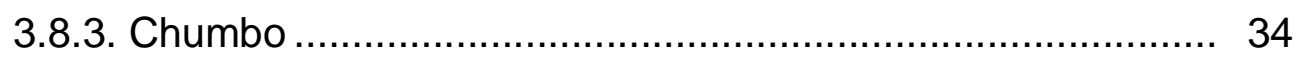

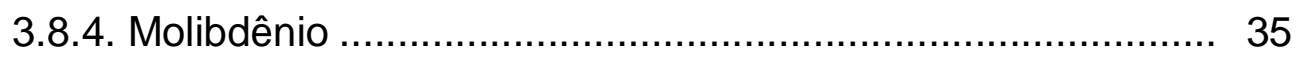

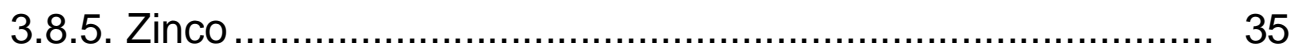

3.9. Estudos em colunas de solo.............................................. 35

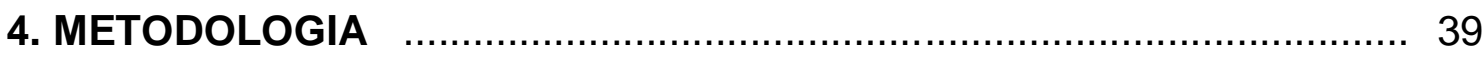

4.1. Cinza de carvão ................................................................ 39

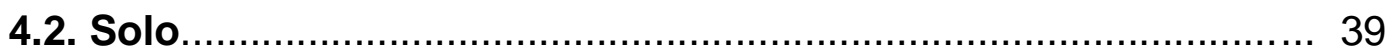

4.3. Montagem das colunas.................................................... 41

4.4. Lixiviação das colunas ........................................................ 44

4.5. Determinação da vazão e do coeficiente de permeabilidade das colunas................................................................................. 47

4.6. Desmontagem das colunas ............................................. 48

4.7. Determinação das propriedades físicas, químicas e

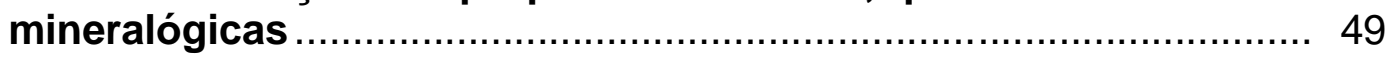

4.7.1. Cinza de carvão............................................................ 49

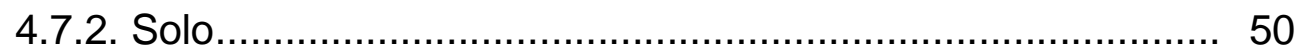

4.7.3. Percolado gerado pela lixiviação das colunas ..................... 53

4.8. Determinação da concentração dos elementos ......................... 53

4.8.1. Determinação da concentração dos elementos majoritários 55 
4.8.2. Determinação da concentração dos elementos tóxicos

4.8.2.1. Determinação da concentração dos elementos tóxicos no percolado

4.8.2.2. Determinação da concentração dos elementos tóxicos nos extratos de solo e cinza de carvão.

4.8.2.2.1. Extratos de solo e cinza de carvão obtidos por digestão ácida em forno de micro-ondas 56

4.8.2.2.2. Extratos de solo obtidos por extração com EDTA-NH $40,05 \mathrm{~mol} \mathrm{~L}^{-1}$

4.8.2.2.3. Extratos de solo obtidos por extração com $\mathrm{Ca}\left(\mathrm{NO}_{3}\right)_{2} 0,1 \mathrm{~mol} \mathrm{~L}^{-1}$

4.9. Tratamento dos dados 60

4.9.1. Coeficiente de partição. 60

4.9.2. Especiação dos elementos tóxicos..................................... 6

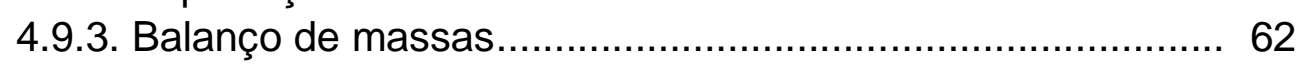

4.9.4. Matriz de correlação ......................................................... 63

4.10. Fluxograma da metodologia do estudo ................................ 63

5. RESULTADOS E DISCUSSÕES........................................................... 65

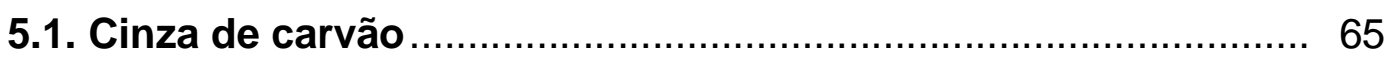

5.1.1. Caracterização física e química da cinza de carvão............. 65

5.1.2. Caracterização mineralógica da cinza de carvão ................. 67

5.2. Solo.

5.2.1. Caracterização física e química do solo não lixiviado............ 68

5.2.2. Caracterização mineralógica do solo não lixiviado............... 76

5.2.3. Caracterização química do solo lixiviado ............................. 78

5.3. Percolado das colunas ........................................................... 81

5.3.1. Caracterização química dos percolados............................. 81

5.3.1.1. pH dos percolados ............................................ 82

5.3.1.2. Condutividade elétrica dos percolados .................... 83

5.3.1.3. Concentração de CTD, COD e CID dos percolados.. 84

5.3.2. Concentração de Al, Fe e Mn nos percolados..................... 87

5.3.2.1. Concentração de alumínio nos percolados ............... 87

5.3.2.2. Concentração de ferro nos percolados .................... 88

5.3.2.3. Concentração de manganês nos percolados............ 89

5.3.3. Concentração dos ânions nos percolados ........................... 90

5.3.4. Concentração dos elementos majoritários nos percolados... 92

5.4. Determinação das vazões e coeficiente de permeabilidade das colunas....................................................................... 93

5.5. Determinação dos elementos tóxicos........................................ 96

5.5.1. Concentração dos elementos no percolado ....................... 96

5.5.1.1. Chumbo.......................................................... 96

5.5.1.2. Arsênio ……....................................................... 97

5.5.1.3. Molibdênio ............................................................. 99

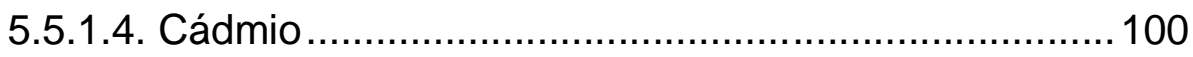

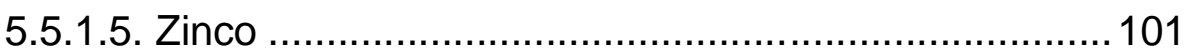

5.5.2. Massa dos elementos no percolado (mp).........................102 
5.5.3. Comparação entre a concentração dos elementos nos percolados e o valor de referência ambiental

5.5.4. Concentração dos elementos na cinza de carvão........104

5.5.4.1. Massa do elemento lixiviado da cinza de carvão (mc)

5.5.5. Concentração dos elementos no solo …………................109

5.5.5.1. Concentração parcial............................................. 109

5.5.5.2. Massa do elemento no solo (ms)........................... 113

5.5.5.3. Comparação entre a concentração dos elementos no solo e o valor de referência ambiental........................... 114

5.5.5.4. Concentração biodisponível ......................................115

5.5.5.5. Concentração trocável............................................. 117

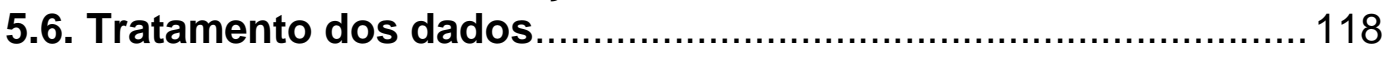

5.6.1. Coeficiente de partição ....................................................118

5.6.2. Especiação dos elementos tóxicos....................................120

5.6.3. Correlação entre os dados obtidos nos percolados das

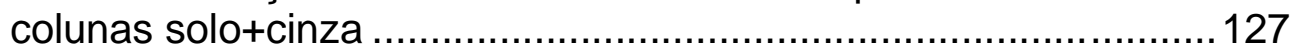

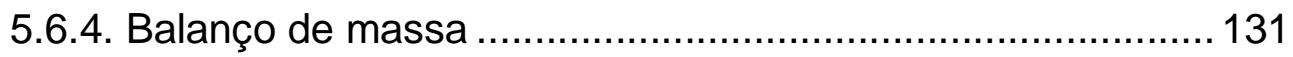

5.6.4.1. Balanço de massa - Arsênio ....................................131

5.6.4.2. Balanço de massa - Molibdênio ............................... 132

5.6.4.3. Balanço de massa - Cádmio ................................... 132

5.6.4.4. Balanço de massa - Zinco ...................................... 134

6. CONCLUSÕES

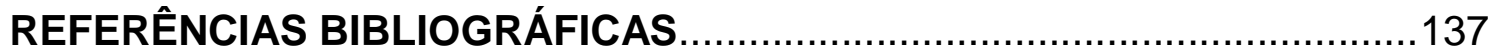

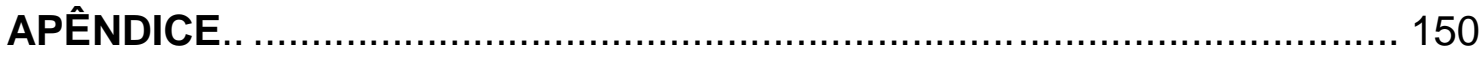




\section{LISTA DE TABELAS}

TABELA 1. Grupos de argilominerais ...................................................... 7

TABELA 2. Componentes orgânicos majoritários nos solos ......................... 9

TABELA 3. Principais grupos funcionais encontrados nos compostos orgânicos presentes nos solos ............................................... 10

TABELA 4. Elementos traços mais comuns em minerais primários ............. 14

TABELA 5. Concentração natural de alguns elementos tóxicos em solos mundiais e paulistas.......................................................... 15

TABELA 6. Frações do solo nas quais os elementos podem estar ligados....17

TABELA 7. Formas de acidez superficial em solos .................................. 18

TABELA 8. Mobilidade de alguns elementos tóxicos em solo ..................... 20

TABELA 9. Seletividade de metais frente a diferentes materiais do solo ..... 23

TABELA 10. Usinas termelétricas em operação no Brasil ............................ 29

TABELA 11. Concentração em $\mathrm{mg} \mathrm{kg}^{-1}$ dos elementos traços nas cinzas volantes de carvão brasileiras ................................................ 31

TABELA 12. Toxicidade dos elementos, essencialidade dos elementos em organismos vivos e valores de intervenção dos elementos no solo e água subterrânea........................................................ 32

TABELA 13. Exemplos de estudos da mobilidade de elementos tóxicos por meio de experimentos em colunas

TABELA 14. Média pluviométrica da cidade de São Paulo (IAG-USP) e volume da solução adicionada em cada coluna........................ 47

TABELA 15. Propriedades físicas determinadas no solo não lixiviado........... 51

TABELA 16. Propriedades químicas determinadas no solo não lixiviado ...... 52

TABELA 17. Especificações e condições adotadas no cromatógrafo de

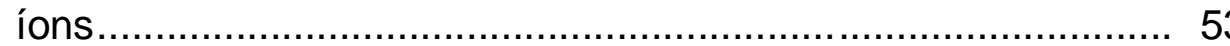

TABELA 18. Composição química da cinza de carvão obtida por

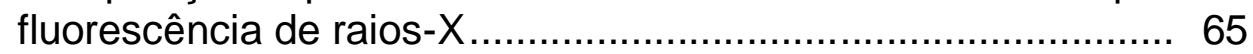

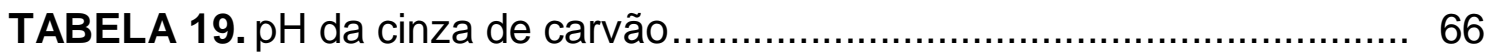

TABELA 20. Propriedades físicas do solo não lixiviado ................................6 68

TABELA 21. Composição química do solo obtido por fluorescência de raios-X

TABELA 22. Propriedades químicas do solo não lixiviado ............................. 72

TABELA 23. $\mathrm{pH}_{\mathrm{KCl}}, \mathrm{pH}_{\mathrm{H} 2 \mathrm{O}}$ e $\Delta \mathrm{pH}$ do solo após lixiviação .............................. 79

TABELA 24. Porcentagem dos óxidos $\mathrm{Al}_{2} \mathrm{O}_{3}, \mathrm{Fe}_{2} \mathrm{O}_{3}$ e $\mathrm{MnO}$ no solo após

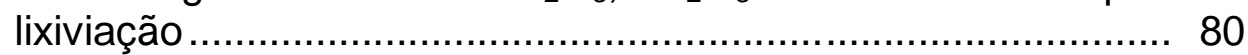

TABELA 25. Concentração dos ânions nos percolados das colunas ............. 90

TABELA 26. Concentração dos elementos majoritários nos percolados das

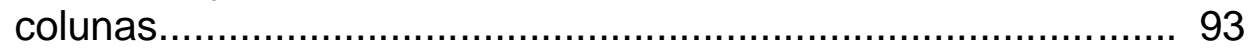

TABELA 27. Massa total dos elementos no percolado das colunas ...............103

TABELA 28. Concentração dos elementos no percolado das colunas e valor de intervenção para água subterrânea do Estado de São Paulo. 
TABELA 29. Concentração dos elementos nas amostras de cinza de carvão.

TABELA 30. Massa dos elementos na cinza de carvão lixiviada ...................107

TABELA 31. Massa dos elementos lixiviados da cinza de

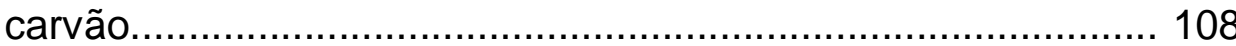

TABELA 32. Percentual de lixiviação dos elementos da cinza de carvão...... 109

TABELA 33. Concentração dos elementos $\left(\mathrm{mg} \mathrm{kg}^{-1}\right)$ nas amostras dos materiais de referência.

TABELA 34. Concentração dos elementos $\left(\mathrm{mg} \mathrm{kg}^{-1}\right)$ no solo não lixiviado e lixiviado obtida pela digestão ácida parcial

TABELA 35. Massa dos elementos retida no solo lixiviado..............................113

TABELA 36. Percentual de retenção dos elementos no solo .........................114

TABELA 37. Concentração média dos elementos no solo das colunas de solo+cinza após lixiviação e valores orientadores.

TABELA 38. Concentração dos elementos $\left(\mathrm{mg} \mathrm{kg}^{-1}\right)$ na amostra de solo certificado obtida pela extração com EDTA-NH

TABELA 39. Concentração dos elementos $\left(\mathrm{mg} \mathrm{kg}^{-1}\right)$ no solo obtida pela extração com EDTA-NH $\mathrm{NH}_{4}$ após lixiviação

TABELA 40. Concentração de $\mathrm{Zn}\left(\mathrm{mg} \mathrm{kg}^{-1}\right)$ no solo após lixiviação obtida pela extração com $\mathrm{Ca}\left(\mathrm{NO}_{3}\right)_{2}$

TABELA 41. Valores de Kp obtidos para o $\mathrm{Zn}$

TABELA 42. Concentração das espécies de As, Mo, Cd e Zn no percolado das colunas de cinza estimada pelo modelo PHREEQC

TABELA 43. Concentração das espécies de As e $\mathrm{Zn}$ no percolado das colunas de solo+cinza estimada pelo modelo PHREEQC.

TABELA 44. Índice de saturação dos principais minerais presentes no percolado das colunas de solo+cinza obtido pelo modelo PHREEQC

TABELA 45. Correlação de As e $\mathrm{Zn}$ com as propriedades físicas e químicas no percolado das colunas de solo+cinza 


\section{LISTA DE FIGURAS}

FIGURA 1. Constituintes do solo

FIGURA 2. Distribuição típica dos minerais primários e secundários, nas diferentes frações de solo...

FIGURA 3. Ilustração dos complexos de superfície .................................. 12

FIGURA 4. Ilustração da dupla camada elétrica e camada iônica difusa ...... 13

FIGURA 5. Relação genérica entre o pH do solo e a quantidade de ácido ou base adicionada............................................................... 19

FIGURA 6. Solubilidade de um hidróxido metálico em relação ao pH.......... 20

FIGURA 7. Mapa de Solos do Brasil atualizado segundo o atual Sistema Brasileiro de Classificação de Solos........................................ 26

FIGURA 8. Coleta do solo no Estado de São Paulo..................................... 40

FIGURA 9. Grupos de colunas ........................................................... 41

FIGURA 10. Montagem das colunas de solo.............................................. 42

FIGURA 11. Coluna de cinza de carvão (grupo 3) .................................... 44

FIGURA 12. Sistema de lixiviação das colunas de solo e colunas de cinza. Fotos 1, 3 e 4: colunas de solo. Foto 2: colunas de cinza........... 45

FIGURA 13. Esquema da lixiviação das colunas......................................... 46

FIGURA 14. Volume adicionado e percolado das colunas ao longo do

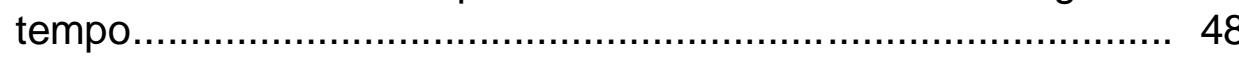

FIGURA 15. Desmontagem das colunas. Foto 1: coluna de solo desmontada. Foto 2: solo e cinza secando a temperatura ambiente.

FIGURA 16. Esquema da determinação da concentração dos elementos nas amostras de cinza, solo e percolado .................................. 60

FIGURA 17. Fluxograma da metodologia de estudo .....................................64 64

FIGURA 18. Distribuição do tamanho das partículas da cinza de carvão determinada pelo LCT-POLI-USP

FIGURA 19. Difratograma da cinza de carvão obtido no LCT-POLI-USP ...... 67

FIGURA 20. Diagrama de granulometria adotado pela Sociedade Brasileira de Ciência do Solo.

FIGURA 21. Distribuição dos valores de CTC dos solos no Brasil................ 74

FIGURA 22. Exemplo de geração de cargas nos óxidos de alumínio e ferro.. 76

FIGURA 23. Difratograma do solo obtido no LCT-POLI-USP........................ 77

FIGURA 24. Coloração e partículas nos percolados das colunas de solo ..... 79

FIGURA 25. Porcentagem de óxidos de Fe e Al nas amostras de solo ......... 81

FIGURA 26. $\mathrm{pH}$ dos percolados das colunas lixiviadas ao longo de 336

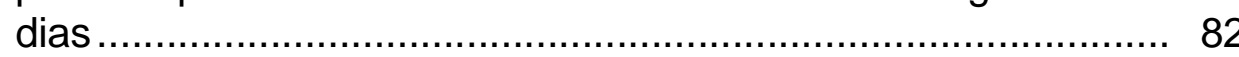

FIGURA 27. Variação do pH no sistema de lixiviação das colunas................ 83

FIGURA 28. Condutividade elétrica dos percolados das colunas lixiviadas ao longo de 336 dias

FIGURA 29. Concentração de carbono total dissolvido (CTD), carbono orgânico dissolvido (COD) e carbono inorgânico dissolvido 
(CID) e volume dos percolados das colunas lixiviadas ao longo de 336 dias....

FIGURA 30. Concentração de Al dos percolados das colunas lixiviadas ao longo de 336 dias.

FIGURA 31. Concentração de Fe dos percolados das colunas lixiviadas ao longo de 336 dias.

FIGURA 32. Concentração de Mn dos percolados das colunas lixiviadas ao longo de 336 dias

FIGURA 33. Mecanismos de complexação de $\mathrm{SO}_{4}{ }^{2-}$ na goethita e hematita

FIGURA 34. Vazão de saída da coluna (---) e volume (-) dos percolados das colunas lixiviadas ao longo de 336 dias

FIGURA 35. Coeficiente de permeabilidade das colunas lixiviadas ao longo de 336 dias

FIGURA 36. Concentração de As dos percolados das colunas lixiviadas ao longo de 336 dias.

FIGURA 37. A: Variação da concentração de As no lixiviado de uma cinza de carvão mediamente alcalina pelo volume do lixiviado obtida por QUEROL et al. (2001). B: Variação da concentração de As no lixiviado da cinza de carvão pelo volume do lixiviado obtida no presente estudo.

FIGURA 38. Concentração de Mo dos percolados das colunas lixiviadas ao longo de 336 dias.

FIGURA 39. A: Variação da concentração de Mo no lixiviado de uma cinza de carvão mediamente alcalina pelo volume lixiviado obtida por QUEROL et al. (2001). B: Variação da concentração de Mo no lixiviado da cinza de carvão pelo volume lixiviado obtida no presente estudo...

FIGURA 40. Concentração de $\mathrm{Cd}$ dos percolados das colunas lixiviadas ao longo de 336 dias

FIGURA 41. Concentração de $\mathrm{Zn}$ dos percolados das colunas lixiviadas ao longo de 336 dias

FIGURA 42. Diagrama de estabilidade das espécies inorgânicas de As.

FIGURA 43. Índices de saturação dos principais minerais contendo As, Cd, Mo e Zn no percolado da cinza de carvão em função do tempo.

FIGURA 44. Esquema da possível distribuição das espécies de As nos compartimentos cinza, solo e percolado do sistema de lixiviação das colunas, com base nos resultados obtidos pelo modelo PHREEQC...

FIGURA 45. Concentração de $\mathrm{Zn}(---)$ e $\mathrm{pH}(-)$ dos percolados das colunas de solo+cinza ao longo de 336 dias.

FIGURA 46. Esquema do balanço de massa em $\mathrm{mg}$ de As no sistema cinza/solo/percolado.

FIGURA 47. Esquema do balanço de massa em mg de Cd no sistema cinza/solo/percolado. 
FIGURA 48. Efeito do tamanho de poros na concentração de $\mathrm{Cd}$ em solução 


\section{INTRODUÇÃO}

A presença de elementos tóxicos no solo pode provocar impacto à qualidade ambiental e saúde humana devido à sua toxicidade. Estudar a mobilidade desses elementos em solos é importante, pois, está relacionado com o transporte destes para a água subterrânea. A contaminação das águas subterrâneas tende a se tornar, cada vez mais, em um problema crítico de saúde pública, devido à precariedade dos sistemas de saneamento básico das águas superficiais, de sua quantidade insuficiente e considerando-se os custos elevados dos sistemas de tratamento de água a níveis de potabilidade.

A contaminação de solos pode resultar no desequilíbrio físico, químico e biológico dos solos. Os elementos tóxicos são considerados perigosos poluentes em solo, pois afetam ciclos biogeoquímicos e se acumulam em organismos vivos, sendo eventualmente, transportados para humanos via cadeia alimentar. Além disso, a poluição de solos por esses elementos tóxicos pode inibir a atividade de enzimas microbianas e reduzir a diversidade de populações da flora e fauna do solo.

A preocupação crescente com a depreciação da qualidade ambiental dos solos justifica-se pelo fato desse meio físico ser um componente essencial para à vida, pois é utilizado na produção agrícola e pecuária.

Atualmente, são conhecidas diversas fontes contaminantes de solos, tais como: fertilizantes comerciais, resíduos provenientes da queima de carvão, resíduos industriais, emissões automotivas, entre outras (SPARKS, 2003).

Na usina termelétrica a base de carvão, um dos principais problemas ambientais ocasionados é a geração de cinzas, além dos aspectos relacionados à mineração, transporte, estocagem e beneficiamento do carvão e a emissão aérea resultante do processo de combustão. Apesar dos esforços da comunidade científica para o desenvolvimento de energias limpas e renováveis, a matriz energética mundial ainda é altamente dependente das fontes não renováveis e amplamente poluidoras. 
As cinzas de carvão oriundas do processo de combustão em usinas termelétricas são geradas de maneira abundante no mundo todo. Apesar de haver muitos estudos relacionados à utilização dessas cinzas, tais como, a aplicação na indústria de cimentos, cerâmica, concreto, filtros minerais, materiais zeolíticos e de asfalto, a maior fração desta ainda permanece sem destino adequado. Isso é um problema mundial que gera grande preocupação do ponto de vista ambiental e do bem estar dos seres vivos que habitam as imediações dos depositórios dessas cinzas.

No Brasil as cinzas de carvão são comumente dispostas de maneira inadequada sobre o solo nas proximidades das usinas termelétricas. As cinzas brasileiras são compostas de elementos tóxicos, tais como, $\mathrm{As}, \mathrm{Pb}, \mathrm{Zn}, \mathrm{Cd}$ e Mo (DEPOI et. al, 2008; CAMARGO, 2005).

Dados obtidos de estudos de mobilidade dos elementos em experimentos de colunas de lixiviação podem mostrar o comportamento químico desses elementos no solo e na solução do solo, indicando a mobilidade deles. Apesar das incertezas envolvidas, o estudo da mobilidade dos elementos tóxicos em laboratório pode permitir o uso das informações obtidas para auxiliar os processos de remediação de contaminação do solo, evitando ou retardando a possível contaminação da água subterrânea. 


\section{OBJETIVOS}

Os objetivos deste trabalho foram:

1. Avaliar a contaminação do solo por $\mathrm{As}, \mathrm{Cd}, \mathrm{Mo}, \mathrm{Pb}$ e $\mathrm{Zn}$ pela lixiviação de colunas de solo com cinza de carvão;

2. Avaliar mobilidade desses elementos no sistema cinza/solo/percolado

3. Efetuar especiação dos elementos no percolado das colunas.

As informações obtidas poderão auxiliar nos processos de remediação de contaminação de solos. 


\section{REVISÃO DA LITERATURA}

\subsection{Componentes do solo}

O solo é um dos componentes mais multifuncionais do meio ambiente. O Homem dispõe de alimentos que nele crescem, utiliza-o como alicerce para moradias, empresas, indústrias, lazer, ruas e estradas. É largamente aplicado como matéria-prima em diversos setores da indústria e é utilizado como depósito de resíduo industrial e domiciliar (BRADY, 1989).

O solo pode ser definido como um material da Terra modificado por processos físicos, químicos e biológicos, que sustenta a vida vegetal (ART, 2000). É um componente básico do ecossistema e é um dos mais vulneráveis à contaminação e degradação proveniente de uma utilização irresponsável.

Os minerais do solo são compostos inorgânicos provenientes dos processos de intemperismo que pode ser definido como o conjunto de modificações de ordem física (desagregação) e química (decomposição) que as rochas sofrem ao aflorar na superfície da Terra. A maioria dos solos é composta principalmente por partículas pequenas provenientes das rochas expostas ao intemperismo, que são os silicatos minerais. Com o tempo, os silicatos minerais das rochas intemperizadas podem se envolver em reações químicas, formando os argilominerais, que juntamente com os materiais orgânicos, constituem a fase sólida do solo. Além dos minerais e da matéria orgânica, os outros componentes importantes do solo são água e ar, que ocupam o espaço poroso do solo (BAIRD, 2002), conforme exposto na FIG.1. Assim sendo, o solo é um material heterogêneo cujas características variam conforme a rocha matriz, relevo, clima, vegetação, biosfera e por isso permanece em constante transformação, sendo considerado um sistema dinâmico, multifásico (TEXEIRA, 2008) e complexo. 


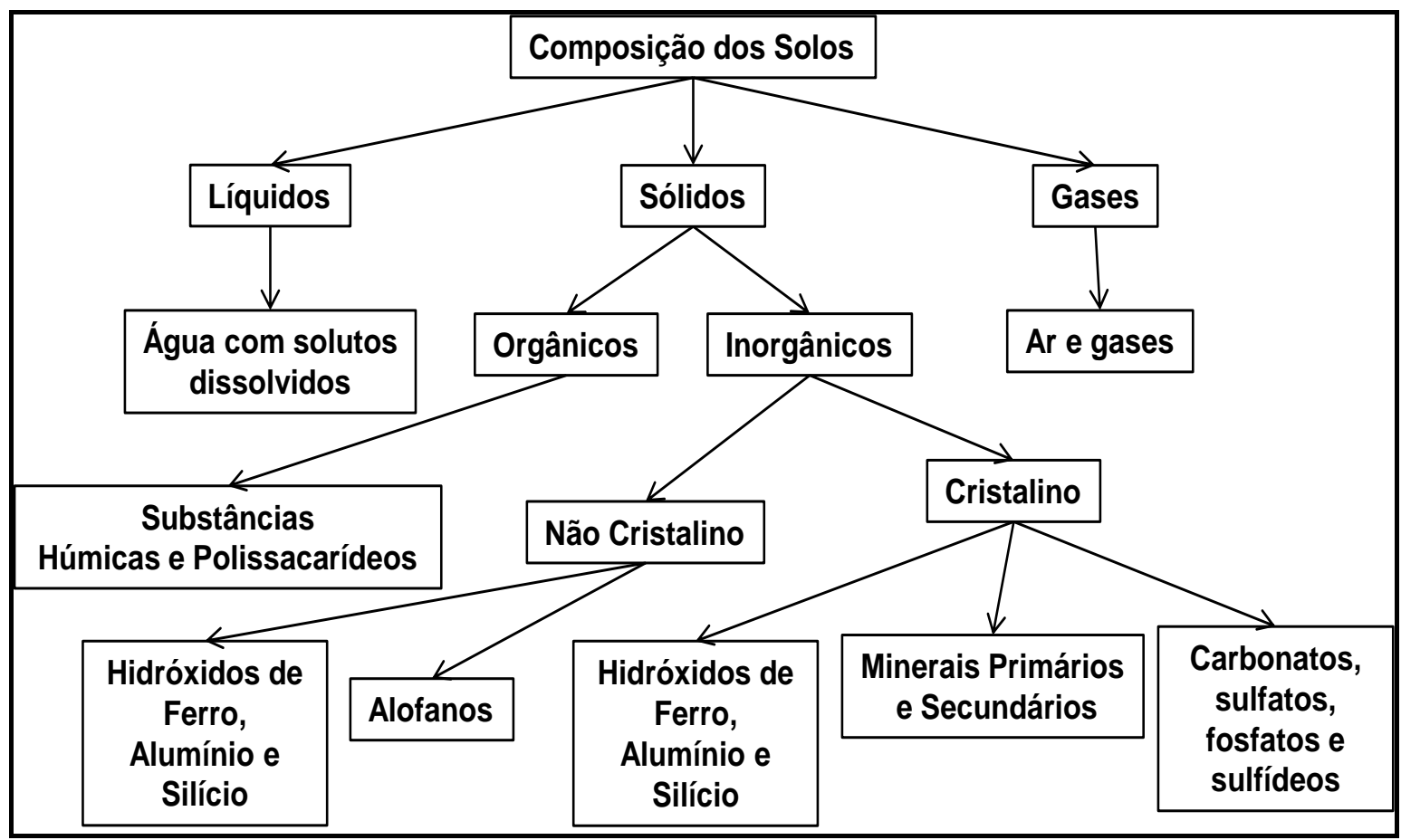

FIGURA 1 - Constituintes do solo (Fonte: YONG e MULLIGAN, 2004)

\subsubsection{A fase sólida do solo}

Na maioria dos solos, mais da metade do volume total é ocupado pela fase sólida, que geralmente é composta majoritariamente por compostos inorgânicos. Porém em alguns solos tipicamente orgânicos é possível encontrar porcentagens de matéria orgânica acima dos 50\% (SPOSITO, 1989).

\subsubsection{Os constituintes inorgânicos do solo}

Cerca de 99\% da composição da crosta terrestre é atribuída aos elementos O, Si, Al, Fe, Ca, Na, K, Mg, Ti e P, sendo 70\% dessa composta por silício e oxigênio. Todos os demais elementos são denominados elementos traços, que ocorrem como constituintes dos minerais primários em rochas ígneas ou pela substituição isomórfica na estrutura cristalina do mineral.

As partículas minerais do solo podem ser classificadas tanto quanto à dimensão de suas partículas como sua origem e composição. Quanto à origem essas podem ser divididas como minerais primários (remanescentes da rocha que deu origem ao solo) ou minerais secundários (decompostos e/ou recompostos depois da intemperização dos minerais primários). Quanto à granulometria os 
minerais podem ser classificados como argila, silte e areia, sendo a argila a porção mais fina do solo e a areia a mais grossa (LEPSCH, 2002).

Os minerais primários são constituintes majoritários das frações de silte e areia do solo, porém são constituintes minoritários na fração argilosa. $O$ principal grupo de minerais primários são os silicatos, tais como, quartzo, felsdspato, feldspatóides, olivinas, piroxênios, anfibólios e micas (SPOSITO, 1989). Como esses minerais são compostos tipicamente por partículas grandes quando comparados com os argilominerais (minerais secundários), possuem baixa área superficial específica e por isso são pouco importantes no processo de atenuação e interação com contaminantes (YONG e MULLIGAN, 2004), como elementos tóxicos.

Os minerais secundários são formados por camadas de silicatos (filossilicatos hidratados) e são os constituintes majoritários da fração argilosa do solo. Uma importante classe desses minerais são os denominados argilominerais que são minerais em que os cátions de $\mathrm{Si}^{4+}$ são substituídos por cátions de $\mathrm{Al}^{3+} \mathrm{e}$ este por cátions de metais bivalentes. Essa substituição por íons de tamanhos aproximados é denominada como substituição isomórfica e é responsável pela presença de cargas elétricas negativas na superfície dos argilominerais, que tendem a ser balanceadas por cátions hidratados de $\mathrm{Na}^{+}, \mathrm{K}^{+}$e $\mathrm{NH}_{4}^{+}$presentes na solução do solo. A combinação entre uma alta área superficial específica e a presença significativa de cargas superficiais faz com que esses minerais atuem de forma importante no processo de atenuação e interação com contaminantes (SPOSITO, 1989; YONG e MULLIGAN, 2004; MCBRIDE, 1994), tais como, elementos tóxicos.

Os argilominerais são classificados em cinco grupos diferenciados pelo tipo de substituição isomórfica, pelo tipo de camadas combinadas e pela carga da camada (SPOSITO, 1989). A camada 1:1 é formada pelo arranjo de uma folha tetraédrica e uma folha octaédrica e a camada 2:1 é formada por uma folha octaédrica entre duas tetraédricas. A carga da camada representa o número de moles de carga elétrica excedente por fórmula química, ocasionada pela substituição isomórfica e é um dos principais parâmetros a ser considerado na 
mobilidade dos elementos em solos, pois há uma tendência que os elementos fiquem mais retidos nos grupos de argilominerais de maior carga. Na TAB.1 os valores de carga dos argilominerais estão associados ao diferentes arranjos de camadas.

TABELA 1 - Grupos de argilominerais

\begin{tabular}{lcclc}
\hline \multirow{1}{*}{ Grupo } & $\begin{array}{c}\text { Tipo de } \\
\text { Camada }\end{array}$ & $\begin{array}{c}\text { Carga } \\
\text { Estequiométrica }\end{array}$ & \multicolumn{1}{c}{ Fórmula } & CTC $\left(\mathrm{mmol}_{\mathrm{c}} \mathrm{kg}^{-1}\right)$ \\
\hline Caulinita & $1: 1$ & $<0.01$ & {$\left[\mathrm{Si}_{4}\right] \mathrm{Al}_{4} \mathrm{O}_{10}(\mathrm{OH})_{8}$} & $100-150$ \\
llita & $2: 1$ & $1,4-2,0$ & $\mathrm{M}_{\times}\left[\mathrm{Si}_{6.8} \mathrm{Al}_{1.2}\right] \mathrm{Al}_{3} \mathrm{Fe}_{0.25} \mathrm{Mg}_{0.75} \mathrm{O}_{20}(\mathrm{OH})_{4}$ & $1000-4000$ \\
Vermiculita & $2: 1$ & $1,2-1,8$ & $\mathrm{M}_{\times}\left[\mathrm{Si}_{7} \mathrm{Al}_{\mathrm{Al}} \mathrm{Al}_{3} \mathrm{Fe}_{0.5} \mathrm{Mg}_{0.5} \mathrm{O}_{20}(\mathrm{OH})_{4}\right.$ & $10000-15000$ \\
Smectita & $2: 1$ & $0,5-1,2$ & $\mathrm{M}_{\times}\left[\mathrm{Si}_{8}\right] \mathrm{Al}_{3.2} \mathrm{Fe}_{0.2} \mathrm{Mg}_{0.6} \mathrm{O}_{20}(\mathrm{OH})_{4}$ & $7000-12000$ \\
Clorita & $2: 1$ & Variável & $\left(\mathrm{Al}(\mathrm{OH})_{2.55}\right)_{4 .}\left[\mathrm{Si}_{6.8} \mathrm{Al}_{1.2}\right] \mathrm{Al}_{3.4} \mathrm{Mg}_{0.6} \mathrm{O}_{20}(\mathrm{OH})_{4}$ & $1000-4000$ \\
\hline
\end{tabular}

$\mathrm{M}=$ cátion monovalente; $\mathrm{CTC}=$ capacidade de troca catiônica. Adaptado de: SPOSITO (1989) e McBRIDE, (1994)

Os argilominerais que apresentam camada 2:1 (TAB.1) são aqueles que possuem elevada capacidade de troca catiônica (CTC) e por isso tendem a reter mais elementos tóxicos quando comparados aos minerais de camada 1:1, tal qual a caulinita que apresenta baixa CTC.

Os óxidos e hidróxidos são outros constituintes inorgânicos importantes do solo, principalmente em solos tropicais, formados por um intenso intemperismo. Nesses solos, há uma grande fração de minerais não silicatados formados por folhas de alumínio, ferro ou manganês com $\mathrm{O}^{2-}$ ou $\mathrm{OH}^{-}$. Diferentemente do que ocorre nos argilominerais, esses óxidos e hidróxidos não tendem a sofrer substituições isomórficas e por isso possuem baixa capacidade de troca catiônica, apesar de possuírem, em muitos casos, uma alta área superficial específica. Todavia, essa superfície pode adquirir cargas frente a variações do pH da solução do solo (MCBRIDE, 1994).

Outro tipo de mineral que pode ser encontrado em solos tropicais são os minerais não cristalinos, tais como alofanos, que apesar de possuírem estrutura variável, são basicamente constituídos por partículas esféricas extremamente pequenas de aluminossilicatos e podem desenvolver mais carga por unidade de peso que os óxidos cristalinos de alumínio e ferro (MCBRIDE, 1994). 
Os carbonatos e sulfatos formam uma classe bem comum de minerais, sendo formados principalmente como carbonatos e sulfatos de cálcio, magnésio e sódio, que podem ser oriundos da rocha matriz ou ainda provenientes da precipitação quando em soluções saturadas desses cátions no solo. Entre os minerais carbonatados mais conhecidos estão calcita, dolomita e entre os sulfatados estão gipsita, anidrita e epsomita (SPOSITO, 1989).

Na FIG.2 foi ilustrada qualitativamente a predominância dos minerais secundários na fração argilosa do solo, bem como, exemplifica os principais tipos de minerais primários e secundários.

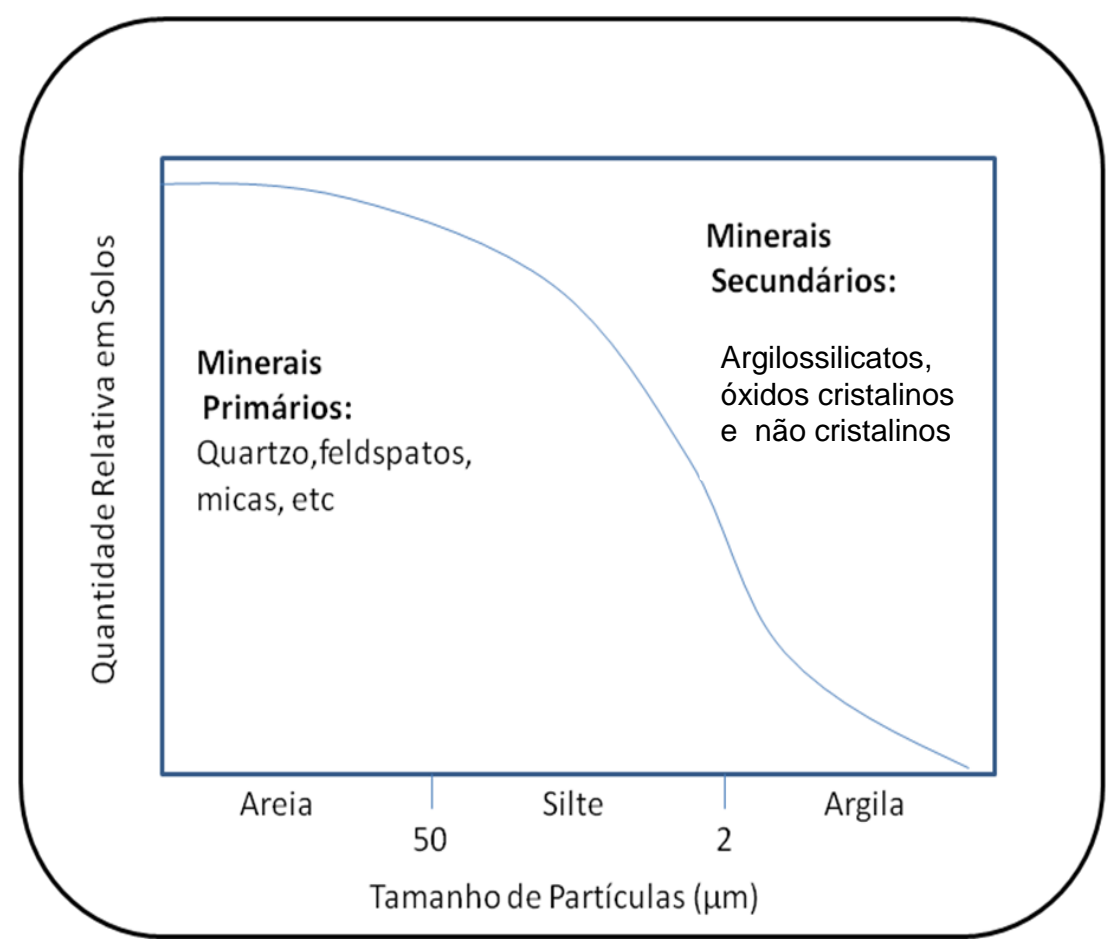

FIGURA 2 - Distribuição típica dos minerais primários e secundários, nas diferentes frações do solo (Fonte: McBRIDE, 1994)

\subsubsection{A matéria orgânica do solo}

A matéria orgânica é um dos principais constituintes da fase sólida do solo e é proveniente da presença de materiais de origem vegetal como as folhas, raízes, caules, frutas e outros detritos vegetais ou de origem animal, como os corpos de vermes, micróbios e esterco. 
À medida que as fontes de materiais vegetais e animais vão se decompondo, por um processo denominado mineralização, ocorre a formação de diversos tipos de compostos orgânicos, cuja estabilidade depende do grau de mineralização dos mesmos. Na TAB.2 estão listados os componentes orgânicos majoritários em solos. Esses componentes auxiliam na sustentação do solo, pois atuam como aglutinante na formação dos agregados, melhorando características físicas, tais como, permeabilidade, porosidade e retenção de água para uso agrícola.

TABELA 2 - Componentes orgânicos majoritários nos solos

\begin{tabular}{|c|c|c|}
\hline Componente & Composição & Importância \\
\hline Húmus & $\begin{array}{l}\text { Resíduo de degradação de plantas, } \\
\text { composto por } \mathrm{C}, \mathrm{H} \text { e O }\end{array}$ & $\begin{array}{l}\text { Componente orgânico mais abundante que } \\
\text { melhora as propriedades físicas e de troca de } \\
\text { nutrientes, reservas e fixação de N. }\end{array}$ \\
\hline $\begin{array}{l}\text { Gorduras, } \\
\text { Resinas e Ceras }\end{array}$ & Lipídeos & $\begin{array}{l}\text { Pode repelir água e em alguns casos causar } \\
\text { fitotoxicidade }\end{array}$ \\
\hline Sacarídeos & Celulose, amidos, hemi-celulose, gomas & $\begin{array}{l}\text { Principal fonte de alimentos para } \\
\text { microorganismos do solo e ajuda estabilizar } \\
\text { agregados }\end{array}$ \\
\hline $\begin{array}{l}\text { Orgânicos } \\
\text { contendo } \\
\text { Nitrogênio }\end{array}$ & $\begin{array}{l}\text { Nitrogênio ligado ao húmus, aminoácidos, } \\
\text { açúcares aminos e outros compostos }\end{array}$ & $\begin{array}{l}\text { Principal fonte de nitrogênio para fertilidade do } \\
\text { solo }\end{array}$ \\
\hline $\begin{array}{l}\text { Compostos de } \\
\text { Fósforo }\end{array}$ & Ésteres fosfatados, fosfatos, fosfolipídios & $\begin{array}{l}\text { Principal fonte de fósforo para fertilidade do } \\
\text { solo }\end{array}$ \\
\hline
\end{tabular}

A matéria orgânica do solo pode ser classificada em duas grandes categorias generalistas como substâncias húmicas e substâncias não húmicas, sendo que as não húmicas são aquelas que possuem propriedades químicas bem definidas. As substâncias húmicas são polímeros amorfos que podem ser classificados conforme sua solubilidade em ácidos: ácidos húmicos (solúveis em bases diluídas), ácidos fúlvicos (solúveis em ácidos e bases diluídas) e huminas (insolúveis em ácidos e bases diluídas) (BAIRD, 2002).

Uma das características mais importantes desses compostos orgânicos é a presença de grupos funcionais que podem ser doadores e receptores de elétrons e por isso podem afetar a mobilização de cátions metálicos na solução do solo e ainda podem agir como agentes tamponantes do solo. Os principais grupos 
funcionais que podem ser encontrados nos compostos orgânicos presentes nos solos estão listados na TAB.3.

TABELA 3 - Principais grupos funcionais encontrados nos compostos orgânicos presentes nos solos

\begin{tabular}{lc}
\hline Grupo Funcional & Fórmula Estrutural \\
\hline Carboxila & $\mathrm{R}-\mathrm{COOH}$ \\
Enol & $\mathrm{R}-\mathrm{CH}=\mathrm{CH}-\mathrm{OH}$ \\
OH fenólica & $\mathrm{Ar}=\mathrm{OH}$ \\
Quinona & $\mathrm{Ar}=\mathrm{O}$ \\
OH-alcoólico & $\mathrm{R}-\mathrm{CH}-\mathrm{OH}$ \\
Éter & $\mathrm{R}-\mathrm{CH}_{2}-\mathrm{O}-\mathrm{CH} \mathrm{CH}_{2}-\mathrm{R}$ \\
Cetona & $\mathrm{R}-\mathrm{C}=\mathrm{O}(-\mathrm{R})$ \\
Aldeído & $\mathrm{R}-\mathrm{CH}=\mathrm{O}$ \\
Éster & $\mathrm{R}-\mathrm{C}=\mathrm{O}(-\mathrm{OR})$ \\
Amina & $\mathrm{R}-\mathrm{CH} \mathrm{H}_{2}-\mathrm{NH}_{2}$ \\
Amida & $\mathrm{R}-\mathrm{C}=\mathrm{O}(-\mathrm{NH}-\mathrm{R})$ \\
Alquila & $-\mathrm{CH}=--\mathrm{CH} \mathrm{H}_{2-,-}-\mathrm{CH}_{3}$ \\
O-alquila & $\mathrm{R}-\mathrm{CH} 2-\mathrm{O}-\mathrm{R}$ \\
\hline R=radical orgânico e Ar=anel aromático. Fonte: MELO e ALLEONI ( 2009) &
\end{tabular}

A matéria orgânica representa uma componente importante no processo de complexação de elementos na solução do solo, pois os grupos funcionais carboxílicos, fenólicos, alcoólicos e cetonas possuem alta afinidade para formação de quelatos com metais tóxicos (YONG e MULLIGAN, 2004).

\subsubsection{A fase líquida do solo}

A solução do solo tem como solvente a água, mas sua composição é extremamente dependente do clima, da ação da vegetação, da composição geológica do solo, da ação da biomassa viva e de ações antrópicas e, por isso, a sua composição é constantemente variável (LEPSCH, 2002).

Geralmente, a concentração de íons na solução do solo é muito superior daquela encontrada na água da chuva e os íons presentes em maior concentração são $\mathrm{Ca}^{2+}, \mathrm{Mg}^{2+}, \mathrm{Na}^{+}, \mathrm{K}^{+}, \mathrm{NH}_{4}^{+}, \mathrm{H}^{+}, \mathrm{Al}^{3+}, \mathrm{NO}^{3-}, \mathrm{SO}_{4}{ }^{2-}, \mathrm{H}_{2} \mathrm{PO}_{4}{ }^{2-}, \mathrm{HCO}_{3}{ }^{-}$ e $\mathrm{CO}_{3}{ }^{2-}$, sendo $\circ \mathrm{pH}$ o principal fator para a variação dessa composição, pois a alteração do mesmo irá influenciar no equilíbrio químico das reações que envolvem a dissolução, precipitação, complexação e sorção desses íons (PIERZYNSKI et al., 1994). Além dos íons citados, na fase líquida do solo há ainda substâncias dissolvidas como sais, substâncias orgânicas e colóides, que 
são partículas sólidas pouco solúveis em água, de diâmetro entre 0,01 e $10 \mu \mathrm{m}$ (SPOSITO, 1989).

As cargas nas superfícies fase sólida do solo e as espécies na solução do solo são influenciadas pela força iônica da solução do solo.

\subsection{As cargas superficiais em solos}

Os componentes sólidos do solo podem adquirir carga elétrica de duas maneiras: 1) substituição isomórfica de um cátion mineral por outro de menor valência, resultando em uma carga elétrica fixa (descrito no item 3.1.1.1); 2) derivada das reações entre íons presentes na solução do solo e grupos de superfície reativos, essas cargas são denominadas como cargas elétricas variáveis (YONG e MULLIGAN, 2004).

Quando grupos ionizáveis, tais como dos óxidos e hidróxidos de Fe e Al ficam expostos na superfície das partículas sólidas, esses podem dissociar íons $\mathrm{H}^{+}$e $\mathrm{OH}^{-}$por meio do contato dessa superfície com a solução do solo gerando as cargas elétricas variáveis. Neste mecanismo ocorre a quebra das moléculas de $\mathrm{H}_{2} \mathrm{O}$ em íons determinadores de potêncial $\mathrm{H}^{+}$e $\mathrm{OH}^{-}$, formando superfícies hidroxiladas, sendo que a carga obtida dependerá do tipo de íon sorvido $\left(\mathrm{H}^{+}\right.$ou $\left.\mathrm{OH}^{-}\right)$. Para valores de $\mathrm{pH}$ baixos (solução ácida) ocorre a protonação das hidroxilas, dando origem às cargas elétricas positivas. Já em pH elevados (solução básica) ocorre o contrário. Os grupos dos óxidos e hidróxidos de $\mathrm{Al}, \mathrm{Fe}, \mathrm{Mn}, \mathrm{Si}$ e Ti são os compostos onde estas reações são mais intensas (MCBRIDE, 1994, SPOSITO, 1989).

Quando há essa interação entre superfícies que se ligam a um íon ou a uma molécula pertencente à solução do solo, ocorre a formação de uma unidade molecular estável denominada como complexo de superfície. Existem dois tipos de complexo de superfície que podem ser (FIG.3):

- Complexo de esfera interna ('inner-sphere"): cátion não hidratado que se situa na superfície do mineral; 
- Complexo de esfera externa ("outer-sphere"): cátion hidratado que se situa sobre a superfície do mineral. Essa ligação é mais fraca e esse cátion pode ser trocado por outros cátions em solução.

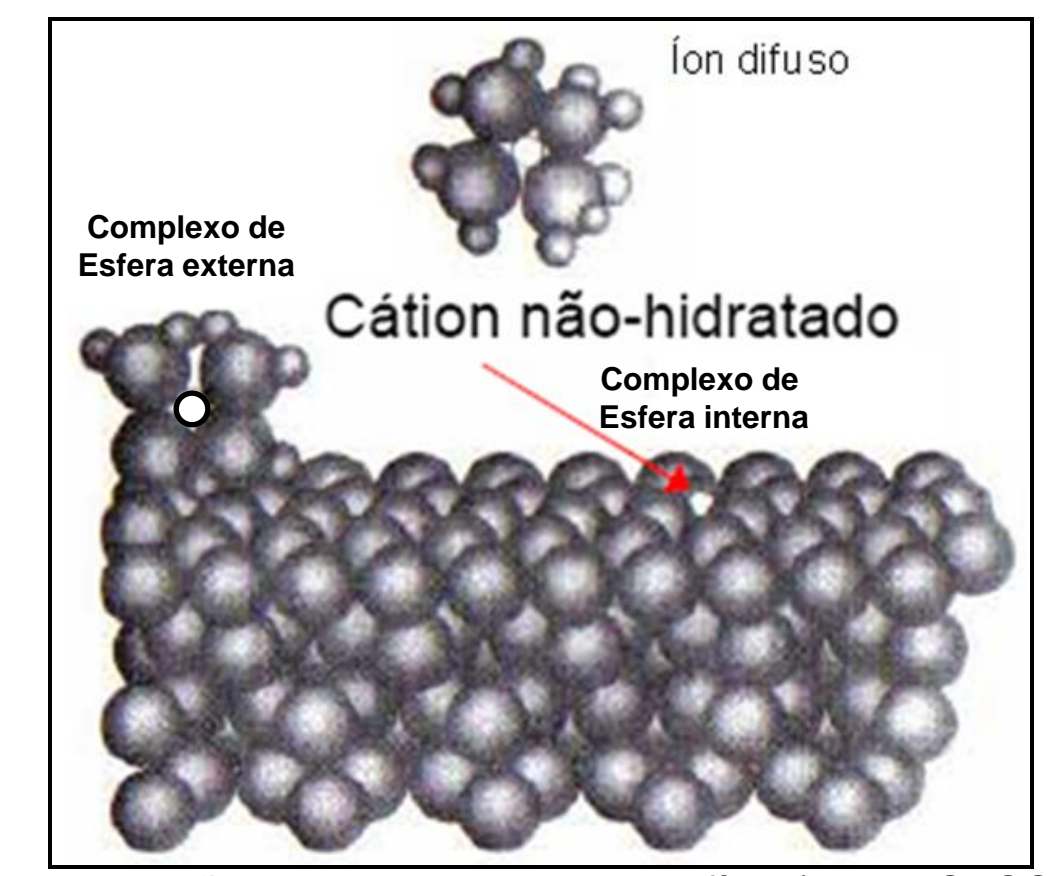

FIGURA 3 - llustração dos complexos de superfície (Fonte: SPOSITO, 1989)

Esses complexos auxiliam no balanceamento de cargas na superfície da fase sólida do solo, que tendem sempre a alcançar a neutralidade.

Os íons difusos presentes na solução do solo podem auxiliar nesse balanceamento, pois a superfície carregada negativamente da fase sólida promove a aproximação de cátions hidratados de forma a promover esse balanço elétrico e à medida que esses cátions se afastam dessa superfície há uma menor orientação dessa camada que vai se tornando difusa. Essa camada é denominada como camada difusa e a camada de maior orientação de cargas mais próxima da superfície é denominada como dupla camada e ambas foram ilustradas na FIG.4. 


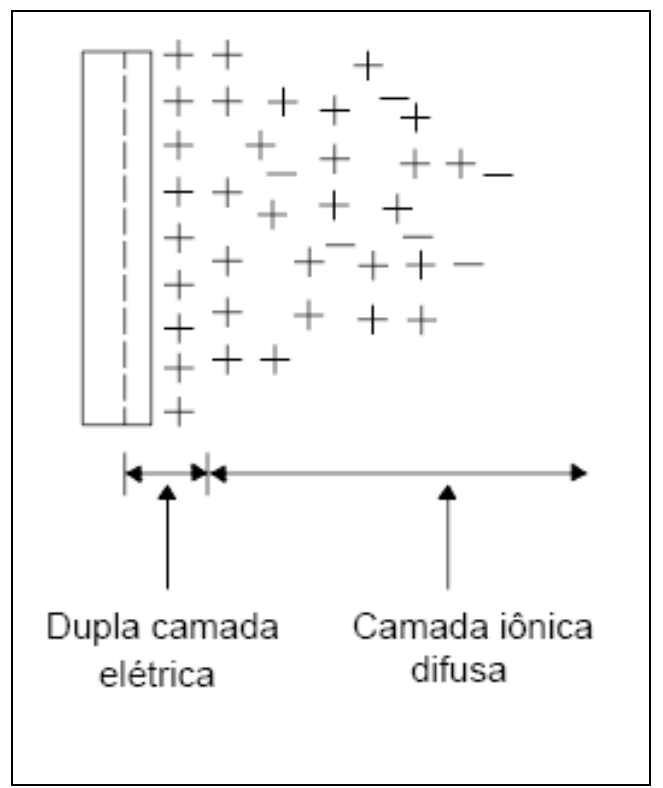

FIGURA 4 - Ilustração da dupla camada elétrica e camada iônica difusa (Adaptado de: SPOSITO, 1989)

A carga líquida total da superfície da fase sólida do solo pode ser expressa pela equação 1 (SPOSITO, 1989):

$\sigma_{p}=\sigma_{o}+\sigma_{H}+\sigma_{I S}+\sigma_{O S}$

Onde:

$\sigma_{0}=$ carga fixa (permanente);

$\sigma_{H}=$ carga líquida de prótons (variáveis);

$\sigma_{I S}=$ carga devida aos complexos esfera interna;

$\sigma_{O S}=$ carga devida aos complexos esfera externa

A carga fixa $\left(\sigma_{\circ}\right)$ da superfície de um sólido no solo é sempre negativa, enquanto que $\sigma_{H}, \sigma_{I S}, \sigma_{O S}$ e $\sigma_{p}$ podem apresentar carga positiva ou negativa, dependendo da composição da solução do solo (SPOSITO, 1989). O denominado ponto de carga zero (PCZ) são valores de $\mathrm{pH}$ em que $\sigma_{\mathrm{p}}$ da equação 1 é nulo (SPOSITO, 1989). 


\subsection{A origem dos elementos tóxicos em solos}

Os elementos tóxicos presentes no solo podem ser de origem natural ou antropogênica. A ocorrência natural depende do tipo de rocha de origem do solo e a antropogênica depende das atividades urbanas, rurais e industriais realizadas sobre o solo.

Os elementos traços mais comuns encontrados nos minerais primários estão listados na TAB.4 (ALLOWAY, 1990).

TABELA 4 - Elementos traços mais comuns em minerais primários

\begin{tabular}{ccc}
\hline Mineral & Traço Constituinte & Suscetibilidade ao intemperismo \\
\hline OLIVINA & $\mathrm{Ni}, \mathrm{Co}, \mathrm{Mn}, \mathrm{Li}, \mathrm{Zn}, \mathrm{Cu}, \mathrm{Mo}$ & \\
HORNBLENDA & $\mathrm{Ni}, \mathrm{Co}, \mathrm{Mn}, \mathrm{Sc}, \mathrm{Lim} \mathrm{V}, \mathrm{Zn}, \mathrm{Cu}, \mathrm{Ga}$ & \\
AUGITA & $\mathrm{Ni}, \mathrm{Co}, \mathrm{Mn}, \mathrm{Sc}, \mathrm{Li}, \mathrm{V}, \mathrm{Zn}, \mathrm{Pb}, \mathrm{Cu}, \mathrm{Ga}$ & \\
BIOTITA & $\mathrm{Rb}, \mathrm{Ba}, \mathrm{Ni}, \mathrm{Co}, \mathrm{Sc}, \mathrm{Li}, \mathrm{Mn}, \mathrm{V}, \mathrm{Zn}, \mathrm{Cu}, \mathrm{Ga}$ & \\
APATITA & Terras raras, $\mathrm{Pb}, \mathrm{Sr}$ & \\
ANORTHITA & $\mathrm{Sr}, \mathrm{Cu}, \mathrm{Ga}, \mathrm{Mn}$ & \\
ANDESINA & $\mathrm{Sr}, \mathrm{Cu}, \mathrm{Ga}, \mathrm{Mn}$ & \\
OLIGOCLÁSIO & $\mathrm{Cu}, \mathrm{Ga}$ & \\
ALBITA & $\mathrm{Cu}, \mathrm{Ga}$ & \\
GARNET & $\mathrm{Cr}, \mathrm{Ga}, \mathrm{Mn}$ & \\
ORTOCLÁSIO & $\mathrm{Rb}, \mathrm{Ba}, \mathrm{Sr}, \mathrm{Cu}, \mathrm{Ga}$ & \\
MUSCOVITA & $\mathrm{F}, \mathrm{Rb}, \mathrm{Ba}, \mathrm{Sr}, \mathrm{Cu}, \mathrm{Ga}, \mathrm{V}$ & \\
TITANITA & $\mathrm{Terras} \mathrm{raras,} \mathrm{V}, \mathrm{Sn}$ & \\
ILMENITA & $\mathrm{Co}, \mathrm{Ni}, \mathrm{Cr}, \mathrm{V}$ & \\
MAGNETITA & $\mathrm{Zn}, \mathrm{Co}, \mathrm{Ni}, \mathrm{Cr}, \mathrm{V}$ & \\
TURMALINA & $\mathrm{Li}, \mathrm{F}, \mathrm{Ga}$ & \\
ZIRCÔNIO & $\mathrm{Hf}, \mathrm{U}$ & Muito resistente ao intemperizado estável \\
QUARTZO & - & \\
\hline
\end{tabular}

Fonte: ALLOWAY (1990)

De acordo com PIERZYNSKI et al. (1994), os elementos traços em solos podem ser subdivididos em três grandes categorias com base nas possíveis formas químicas que esses podem apresentar na solução do solo. Segundo essa classificação, os metais catiônicos são elementos metálicos que tendem estar na solução do solo como cátions, tais como: $\mathrm{Ag}^{+}, \mathrm{Cd}^{2+}, \mathrm{Co}^{2+}, \mathrm{Cr}^{3+}, \mathrm{Cu}^{2+}, \mathrm{Hg}^{2+}, \mathrm{Ni}^{2+}$, $\mathrm{Pb}^{2+}, \mathrm{Zn}^{2+}$, entre outros. Os oxiânions são os elementos que se encontram combinados com o oxigênio formando moléculas de carga negativa, tais como: 
$\mathrm{AsO}_{4}{ }^{3-}, \mathrm{B}(\mathrm{OH})_{4}^{-}, \mathrm{CrO}_{4}{ }^{2-}, \mathrm{MoO}_{4}{ }^{2-}, \mathrm{HSeO}_{3}{ }^{-}, \mathrm{SeO}_{4}{ }^{2-}$, entre outros. Os halogênios são os elementos da família VIIA da tabela periódica e estão presentes na solução do solo como ânions, tais como $\mathrm{F}, \mathrm{Cl}, \mathrm{Br}$ e I. Essas categorias não são exclusivas, uma vez que alguns elementos podem constar em mais de uma categoria.

Muitos elementos traços podem ser oriundos também da decomposição de rochas sedimentares, ou ainda, podem ser encontrados em rochas metamórficas (McBRIDE, 1994).

Valores de concentração natural de elementos tóxicos em solos são bastante heterogêneos (SOARES, 2004). Na TAB.5 estão listados valores de concentração média de alguns elementos tóxicos em solos mundiais (REIMANN e CARITAT, 1998) e no Estado de São Paulo (CETESB, 2005).

TABELA 5 - Concentração natural de alguns elementos tóxicos em solos mundiais e do Estado de São Paulo

\begin{tabular}{ccc}
\hline Elemento & $\begin{array}{c}\text { Solos Mundiais } \\
\text { (REIMANN e CARITAT, 1998) }\end{array}$ & $\begin{array}{c}\text { Solos do Estado de São Paulo } \\
\text { (CESTEB, 2005) }\end{array}$ \\
\hline As & 5 & $\mathrm{mg} \mathrm{kg}^{-1}$ \\
$\mathrm{Mo}$ & 1,2 & 3,5 \\
$\mathrm{Cd}$ & 0,3 & $<4$ \\
$\mathrm{~Pb}$ & 17 & $<0,5$ \\
$\mathrm{Zn}$ & 70 & 17 \\
$\mathrm{Sb}$ & 0,5 & 60 \\
$\mathrm{Ba}$ & 500 & $<0,5$ \\
$\mathrm{Co}$ & 10 & 75 \\
$\mathrm{Cu}$ & 25 & 13 \\
$\mathrm{Cr}$ & 80 & 35 \\
$\mathrm{Hg}$ & 0,05 & 40 \\
$\mathrm{Ni}$ & 20 & 0,05 \\
$\mathrm{Ag}$ & 0,07 & 13 \\
$\mathrm{Se}$ & 0,3 & 0,25 \\
$\mathrm{~V}$ & 90 & 0,25 \\
\hline
\end{tabular}

Segundo ALLOWAY (1990), as principais fontes de elementos tóxicos em solo de origem antrópica são: poluição atmosférica oriunda dos motores veiculares; combustão de combustíveis fósseis, bem como o depósito de cinzas 
resultantes dessa combustão; fertilizantes agrícolas e pesticidas; dejetos orgânicos, tais como estercos e esgotos domésticos ou industriais; disposição de lixos urbanos ou industriais; indústrias metalúrgicas, por emissões atmosféricas, efluentes ou depósito de resíduos de produção; mineração e fundição de metais não ferrosos.

\subsection{Propriedades dos solos e os principais processos de interação entre os elementos e o solo}

Os processos que determinam a mobilidade de elementos tóxicos no solo podem ser tanto de natureza química como física. Os processos físicos que controlam o fluxo de um elemento num meio poroso são a advecção e dispersão hidrodinâmica. A advecção é a componente responsável pela migração do elemento em função da velocidade do fluído e a dispersão hidrodinâmica é a componente responsável pelo espalhamento do elemento devido à variação da sua concentração e a variação da velocidade do fluído, sendo dividida em dispersão mecânica e difusão (FREEZE E CHERRY, 1979).

A mobilidade ou retenção dos elementos tóxicos no solo está relacionada com as reações químicas do elemento tóxico entre a solução do solo e o solo e podem ser agrupadas como reações de: adsorção-dessorção, ácidobase, dissolução-precipitação e pareamento iônico-complexação (FREEZE E CHERRY, 1979). Entretanto, as reações de adsorção-dessorção e precipitaçãodissolução são as que tem efeito direto na transferência do elemento tóxico da fase sólida para a fase líquida do solo (ALLEN et al., 1995).

A intensidade da interação entre o solo e os elementos tóxicos em solução, seja essa química ou física, depende de uma série de propriedades dos solos, porém algumas dessas propriedades são fundamentais nessa relação, tais como pH, argilominerais, óxidos e matéria orgânica (ALLOWAY, 1990) e, por isso, serão melhor detalhadas, antes de serem abordados os processos de interação propriamente ditos.

De acordo com CAMARGO (2005), a intensidade da ligação desses elementos no solo depende da fração com a qual esses estão associados. Essas 
frações são descritas na TAB.6 com base no descrito por HLAVAY et al. (2004) e YONG e MULLIGAN (2004).

TABELA 6 - Frações do solo nas quais os elementos podem estar ligados Fração do solo Intensidade de ligação

Solúvel: inclui elementos solúveis em água e complexos metalo-orgânicos facilmente solúveis.

Trocável (ou facilmente mobilizados): inclui elementos ligados fracamente com o solo, que podem ser substituídos por cátions de mesma valência.

Carbonato: inclui elementos precipitados ou co-precipitados como carbonatos presentes no solo.

Orgânica: inclui elementos associados à matéria orgânica do solo por complexação, adsorção ou por formação de quelatos.

Óxidos: inclui elementos associados aos óxidos Fe, Mn e Al do solo por formação de complexos de superfície, precipitação ou co-precipitação e por ligações forte com a estrutura cristalina.

Residual: inclui elementos ligados a estrutura cristalina dos minerais silicatados do solo.

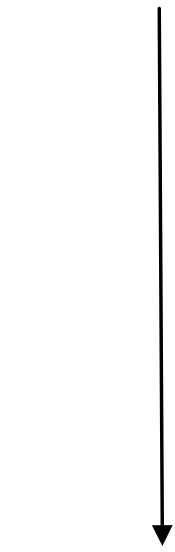

Maior Intensidade

\subsection{1. $\mathrm{pH}$ do solo}

De acordo com McBRIDE (1994) o pH do solo pode ser considerado como a propriedade mais importante no controle das reações de troca iônica, dissolução/precipitação, redução/oxidação, adsorção e complexação.

$\mathrm{Na}$ solução aquosa do solo as possíveis fontes do íon $\mathrm{H}^{+}$estão relacionadas às reações de hidrólise, dissociação e oxidação, tais como (equações 2, 3 e 4):

Hidrólise: $\mathrm{H}_{2} \mathrm{O} \leftrightarrow \mathrm{H}^{+}+\mathrm{OH}^{-}$

Dissociação: $\mathrm{CO}_{2}+\mathrm{H}_{2} \mathrm{O} \leftrightarrow \mathrm{H}_{2} \mathrm{CO}_{3} \leftrightarrow \mathrm{H}^{+}+\mathrm{HCO}_{3}^{-}$

Oxidação: $2 \mathrm{FeS}_{2}+7,5 \mathrm{O}_{2}+7 \mathrm{H}_{2} \mathrm{O} \leftrightarrow \mathrm{Fe}(\mathrm{OH})_{3}+8 \mathrm{H}^{+}+4 \mathrm{SO}_{4}{ }^{2-}$

As reações de hidrólise do alumínio, a adsorção de nutrientes pelas plantas e a aplicação de fertilizantes no solo também contribuem para liberação de $\mathrm{H}^{+}$na solução do solo. 
No solo há uma acidez retida na superfície dos sólidos, tanto na forma explícita (prótons) como na forma latente (geradora de prótons). As principais formas dessa acidez superficial estão listadas na TAB.7 e o conjunto dessas formas corresponde à denominada reserva de acidez do solo (McBRIDE, 1994).

TABELA 7 - Formas de acidez superficial em solos

Forma de acidez superficial

Ácidos orgânicos que liberam $\mathrm{H}^{+}$por dissociação

Complexos orgânicos do tipo $\mathrm{Al}^{+3}$ que liberam $\mathrm{H}^{+}$ por hidrólise

$\mathrm{H}^{+}$e $\mathrm{Al}^{+3}$ trocáveis que liberam $\mathrm{H}^{+}$por troca

catiônica e hidrólise

Formas não trocáveis de $\mathrm{H}^{+}$em minerais

\section{Reação}

\section{$\mathrm{R}-\mathrm{H}=\mathrm{R}^{-}+\mathrm{H}^{+}$}

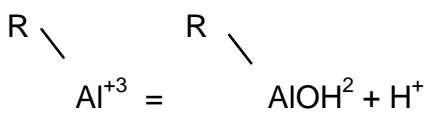

$\mathrm{R} / \mathrm{R} /$

$\mathrm{K}^{+}+\mathrm{H}^{+}$-esmectita $=\mathrm{H}^{+}+\mathrm{K}^{+}$-esmectita $\mathrm{K}^{+}+\mathrm{Al}^{+3}$-esmectita $=\mathrm{AlOH}^{2+}+\mathrm{K}^{+}$-esmectita $+\mathrm{H}^{+}$

$\left.\left.>\mathrm{Fe}-\mathrm{OH}_{2}\right]^{+1 / 2}=>\mathrm{Fe}-\mathrm{OH}\right]^{-1 / 2}+\mathrm{H}^{+}$

$\left.\left.>\mathrm{Al}-\mathrm{OH}_{2}\right]^{+1 / 2}=>\mathrm{Al}-\mathrm{OH}\right]^{-1 / 2}+\mathrm{H}^{+}$

Adaptado de: McBRIDE (1994)

Em outras palavras, os solos comportam-se como ácidos fracos, mantendo seus íons $\mathrm{H}^{+}$ligados até serem influenciados por bases. Portanto, o $\mathrm{pH}$ do solo tende a estar tamponado contra grandes aumentos de $\mathrm{pH}$, dado que seus íons hidrogênio podem ser liberados lentamente para a fase líquida do solo (BAIRD, 2002). Na FIG.5 foi ilustrada a relação genérica entre o pH do solo e a quantidade de ácido ou base adicionada, representando a capacidade tamponante mencionada. 


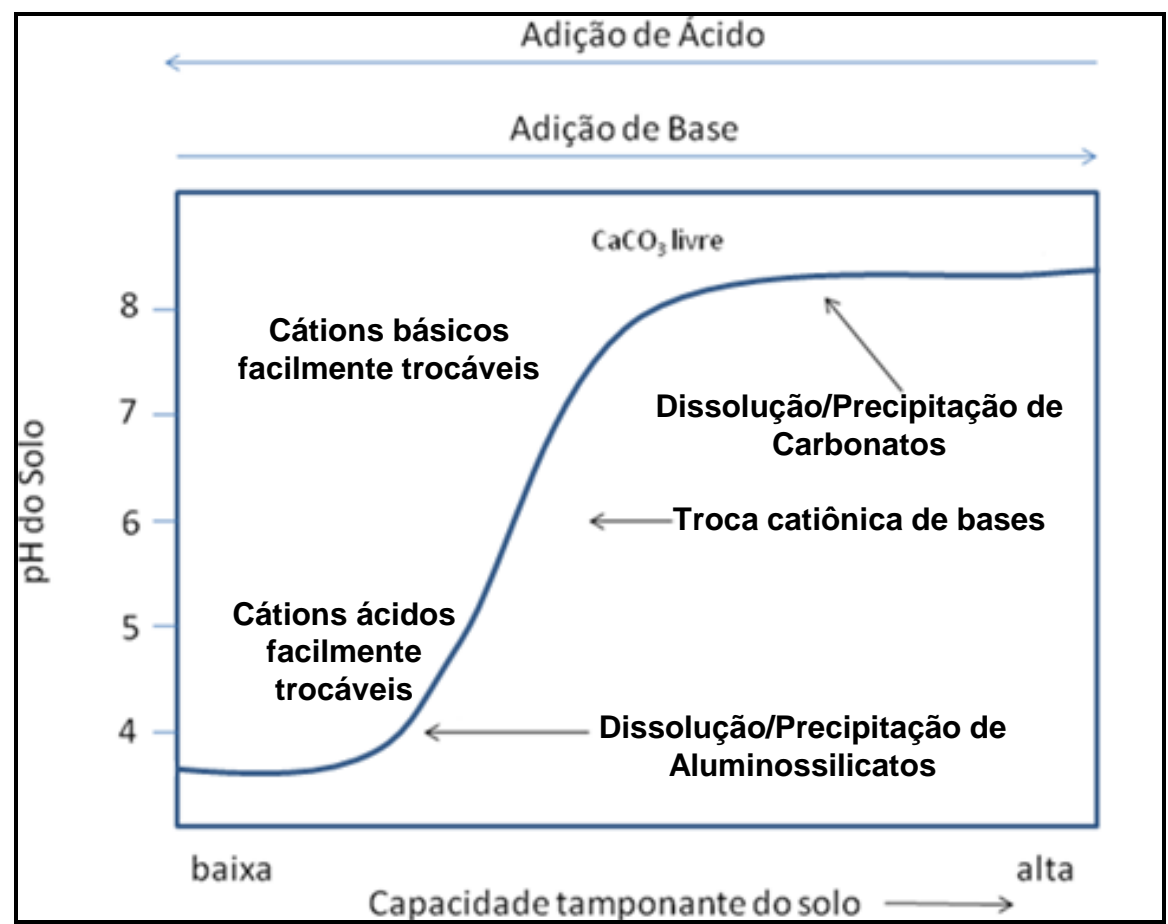

FIGURA 5 - Relação genérica entre o pH do solo e a quantidade de ácido ou base adicionada (Fonte: McBRIDE, 1994)

Mesmo possuindo uma capacidade tamponante, o $\mathrm{pH}$ do solo pode variar significativamente de acordo com flutuações climáticas, ação da biomassa, localização no perfil do solo, oxidação/redução do material de origem, ações antrópicas, etc. $\mathrm{O}$ pH do solo é afetado diretamente por alterações no potencial redox do meio, que são mais acentuadas em regiões em que os solos permanecem longos períodos encharcados. Geralmente, condições redutoras causam um aumento no $\mathrm{pH}$ e condições oxidantes resultam em diminuição do pH (ALLOWAY, 1990).

A dissolução e a consequente mobilidade dos elementos tóxicos pode ser altamente influenciada pela variação do $\mathrm{pH}$. Geralmente, a mobilidade dos cátions metálicos aumenta conforme aumento da acidez do meio. Entretanto, para os oxiânions essa relação já é mais variável. Os oxiânions de As, Mo, Se e Cr tornam-se mais móveis conforme o meio torna-se mais alcalino (PIERZYNSKI et al., 1994). A TAB.8 ilustra a mobilidade relativa de alguns elementos tóxicos em solo em diferentes condições de pH e oxi-redução. 
TABELA 8 - Mobilidade de alguns elementos tóxicos em solo

\begin{tabular}{|c|c|c|c|}
\hline $\begin{array}{l}\text { Mobilidade } \\
\text { Relativa }\end{array}$ & $\begin{array}{c}\text { pH 5-8 } \\
\text { Oxidante }\end{array}$ & $\begin{array}{c}\mathrm{pH}<4 \\
\text { Oxidante }\end{array}$ & Redutor \\
\hline Muito móvel & Mo (Se) & & \\
\hline $\begin{array}{l}\text { Moderadamente } \\
\text { móvel }\end{array}$ & $\mathrm{Zn}, \mathrm{V}, \mathrm{As}(\mathrm{Hg}, \mathrm{Sb})$ & $\begin{array}{c}\mathrm{Zn}, \mathrm{Cd}, \mathrm{Hg}, \mathrm{Cu}, \mathrm{Co}, \mathrm{Ni} \mathrm{V} \\
\text { As, Mn }\end{array}$ & $\mathrm{Mn}$ \\
\hline Pouco móvel & $\begin{array}{c}\mathrm{Mn}, \mathrm{Pb}, \mathrm{Cu}, \mathrm{Ni}, \mathrm{Co} \text {, } \\
\text { (Cd) }\end{array}$ & & $\mathrm{Fe}$ \\
\hline Imóvel & $\mathrm{Fe}, \mathrm{Sc}, \mathrm{Ti}, \mathrm{Sn}(\mathrm{Cr})$ & $\mathrm{Fe}, \mathrm{Sc}, \mathrm{Ti}, \mathrm{Sn}, \mathrm{As}, \mathrm{Mo}, \mathrm{Se}$ & $\begin{array}{c}\mathrm{Fe}, \mathrm{Ti}, \mathrm{Sn}, \mathrm{Cu}, \mathrm{Pb}, \mathrm{Zn}, \mathrm{Cd}, \\
\mathrm{Hg}, \mathrm{Ni}, \mathrm{Co}, \mathrm{AS}, \mathrm{Sb}, \mathrm{V}, \mathrm{Se}, \\
\mathrm{Mo}, \mathrm{Cr}\end{array}$ \\
\hline
\end{tabular}

Fonte: SIEGEL (2002)

O pH também influencia as reações de precipitação dos metais catiônicos, pois com o aumento do pH é favorecida a formação de espécies aniônicas tais como carbonatos, hidroxilas e haletos que reagem facilmente com os cátions metálicos solúveis, conforme exposto na FIG.6. A faixa de precipitação ou dissolução varia conforme o cátion envolvido na ligação com as espécies aniônicas.

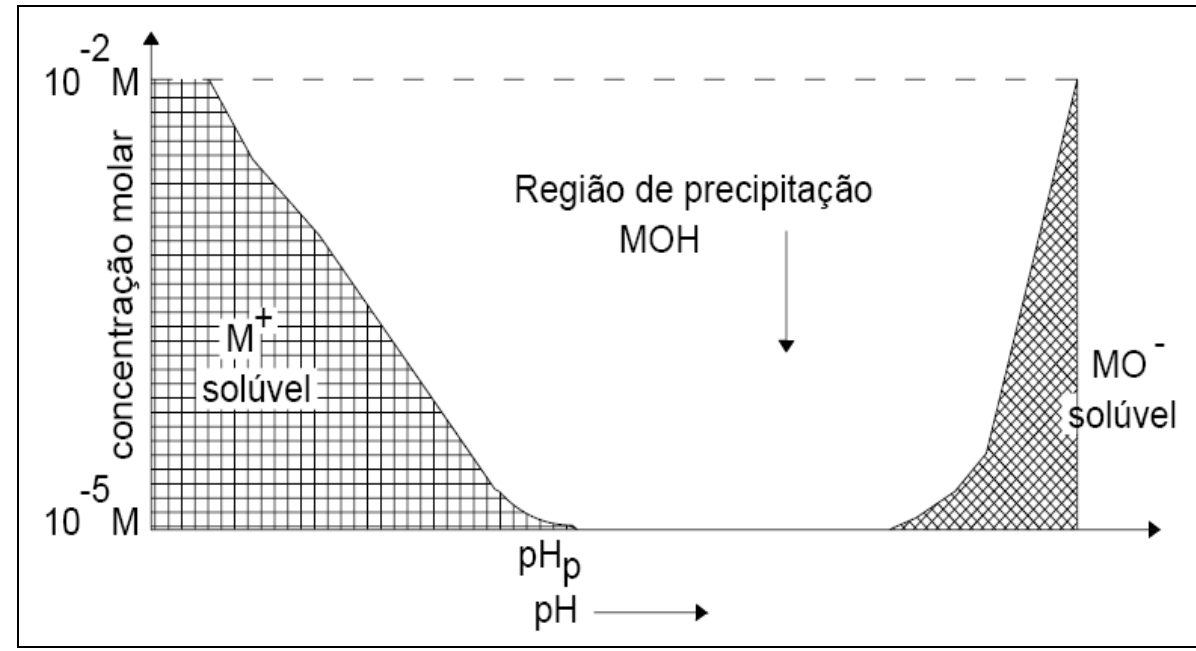

FIGURA 6 - Solubilidade de um hidróxido metálico em relação ao pH (Fonte:

YONG e MULLIGAN, 2004)

Os íons metálicos podem também precipitar pela associação com minerais secundários presentes na fase sólida. Esse tipo de precipitação é denominado por co-precipitação (ALLOWAY, 1990). 


\subsubsection{Matéria orgânica do solo e as reações de complexação}

A matéria orgânica dos solos desempenha um importante papel, pois sua associação com cátions resulta na formação de complexos estáveis. Um complexo é um composto resultante da combinação entre um íon metálico ou uma substância qualquer e um grupo doador de um par de elétrons. Enquanto os cátions monovalentes ( $\mathrm{Na}^{+}, \mathrm{K}^{+}$e outros) encontram-se primariamente envolvidos em processos de troca catiônica por meio da formação de sais de grupos carboxílicos, os cátions multivalentes $\left(\mathrm{Cu}^{2+}, \mathrm{Zn}^{2+}, \mathrm{Mn}^{2+}, \mathrm{Fe}^{3+}\right.$, entre outros) formam ligações químicas mais fortes com as moléculas orgânicas (PIERZYNSKI et al., 1994). Essa diferença entre os cátions monovalentes e multivalentes, pode ser atribuída à eletropositividade (tendência a perder elétrons) de cada metal.

Segundo McBRIDE (1994) a matéria orgânica se liga com alguns metais em $\mathrm{pH}=5$ com a seguinte ordem de afinidade:

$$
\mathrm{Cu}>\mathrm{Ni}>\mathrm{Pb}>\mathrm{Co}>\mathrm{Ca}>\mathrm{Zn}>\mathrm{Mn}>\mathrm{Mg}
$$

Entretanto o mesmo autor ressalta que não há uma regra bem definida para determinar a seletividade de elementos tóxicos pela matéria orgânica, pois essa depende de uma série de fatores, além das propriedades específicas de cada metal, tais como: natureza química dos ligantes orgânicos (tipo de grupo funcional), o nível de adsorção na matéria orgânica, o pH da solução do solo, e por fim, a força iônica da solução em que a adsorção ocorre (que determina a intensidade da competição entre os cátions pelos ligantes).

A matéria orgânica pode também formar complexos metálicos com os íons $\mathrm{Cd}, \mathrm{Cr}$ e outros, e esta complexação pode reter os elementos no solo reduzindo a atividade deles na solução, diminuindo sua toxicidade para as plantas ou a possibilidade de contaminação de águas intersticiais e subterrâneas. Por outro lado, os complexos estáveis formados com as substâncias húmicas podem também ser solúveis e por isso podem ser transportados, aumentando sua disponibilidade para as águas subterrâneas (TEXEIRA, 2008). 
Uma das características mais notáveis da matéria orgânica é que essa apresenta uma alta capacidade de troca catiônica (CTC). Em termos quantitativos, a CTC é definida como a quantidade de cátions que são adsorvidos reversivelmente por unidade de massa seca do solo e ocorre de maneira que a superfície dos sólidos consiga manter a eletroneutralidade.

\subsubsection{A fase sólida do solo e os processos de sorção}

Os processos de sorção podem ser definidos como aqueles que envolvam a remoção de íons da fase líquida para a fase sólida de um determinado sistema (MCBRIDE, 1994). Sendo assim, a remoção de íons da fase líquida pode retardar a mobilidade de elementos tóxicos em solos.

De acordo com SOARES (2004), o termo sorção pode e deve ser usado quando o mecanismo de remoção do soluto da solução é desconhecido, entretanto é mais adequado que seja explicitado o mecanismo de sorção envolvido quando este for reconhecido.

Os principais mecanismos de sorção que ocorrem na superfície de um sólido podem ser classificados como: adsorção, absorção e troca iônica.

Os processos de adsorção dependem principalmente da carga superficial na fase sólida do solo. Como para cada mineral o ponto de carga zero é obtido em um pH específico, a adsorção de um determinado íon metálico por uma fase sólida irá depender de quais minerais compõem essa fase sólida e do pH do meio. Essa relação foi resumida por YONG e MULLIGAN (2004) com base em diferentes referências abordando esse tema, conforme exposto na TAB.9. 
TABELA 9 - Seletividade de metais em relação a diferentes materiais do solo

\begin{tabular}{|c|c|c|}
\hline Material & Ordem de seletividade & Referências \\
\hline Argila caulinítica (pH 3,5-6) & $\mathrm{Pb}>\mathrm{Ca}>\mathrm{Cu}>\mathrm{Mg}>\mathrm{Zn}>\mathrm{Cd}$ & Farrah \& Pickering (1977) \\
\hline Argila caulinítica (pH 5,5-6) & $\mathrm{Cd}>\mathrm{Zn}>\mathrm{Ni}$ & Puls \& Bohn (1988) \\
\hline Argila ilítica $(\mathrm{pH} \mathrm{3,5-6)}$ & $\mathrm{Pb}>\mathrm{Cu}>\mathrm{Zn}>\mathrm{Ca}>\mathrm{Cd}>\mathrm{Mg}$ & Farrah \& Pickering (1977) \\
\hline Argila montmorilonítica (pH 3,5-6) & $\mathrm{Ca}>\mathrm{Pb}>\mathrm{Cu}>\mathrm{Mg}>\mathrm{Cd}>\mathrm{Zn}$ & Farrah \& Pickering (1977) \\
\hline Argila montmorilonítica $(\mathrm{pH} 5,5-7,5)$ & $\mathrm{Cd}=\mathrm{Zn}>\mathrm{Ni}$ & Puls \& Bohn (1988) \\
\hline Óxidos de alumínio (amorfos) & $\mathrm{Cu}>\mathrm{Pb}>\mathrm{Zn}>\mathrm{Cd}$ & Kinninburg et al. (1976) \\
\hline Óxidos de manganês (amorfos) & $\mathrm{Cu}>\mathrm{Zn}$ & Murray (1975) \\
\hline Óxidos de ferro (amorfos) & $\mathrm{Pb}>\mathrm{Cu}>\mathrm{Zn}>\mathrm{Cd}$ & Benjamin \& Leckie (1981) \\
\hline Goethita & $\mathrm{Cu}>\mathrm{Pb}>\mathrm{Zn}>\mathrm{Cd}$ & Forbes et al. (1974) \\
\hline Ácido fúlvico (pH 5,0) & $\mathrm{Cu}>\mathrm{Pb}>\mathrm{Zn}$ & Schnitzer \& Skinner (1967) \\
\hline Ácido húmico (pH 4-6) & $\mathrm{Cu}>\mathrm{Pb}>\mathrm{Cd}>\mathrm{Zn}$ & Stevenson (1977) \\
\hline Solo japonês de origem vulcânica & $\mathrm{Pb}>\mathrm{Cu}>\mathrm{Zn}>\mathrm{Cd}>\mathrm{Ni}$ & Biddappa et al. (1981) \\
\hline $\begin{array}{l}\text { Solos minerais sem matéria orgânica } \\
(\mathrm{pH} 5,0)\end{array}$ & $\mathrm{Pb}>\mathrm{Cu}>\mathrm{Zn}>\mathrm{Cd}$ & Elliot et al. (1986) \\
\hline $\begin{array}{l}\text { Solos minerais contendo de } 20 \text { a } 40 \\
\mathrm{~g} \mathrm{~kg}^{-1} \text { de matéria orgânica }\end{array}$ & $\mathrm{Pb}>\mathrm{Cu}>\mathrm{Cd}>\mathrm{Zn}$ & Elliot et al. (1986) \\
\hline $\begin{array}{l}\text { Ilita, montmorilonita e solos naturais } \\
(\mathrm{pH} 4,0-5,0)\end{array}$ & $\mathrm{Pb}>\mathrm{Cu}>\mathrm{Zn}>\mathrm{Cd}$ & Yong \& Padhungchewit (1993) \\
\hline Caulinita, montmorilonita $(\mathrm{pH}<4)$ & $\mathrm{Pb}>\mathrm{Cd}>\mathrm{Zn}>\mathrm{Cu}$ & Yong \& Padhungchewit (1993) \\
\hline
\end{tabular}

Fonte: YONG e MULLIGAN (2004)

De maneira geral, é possível observar por meio da TAB.9 que o $\mathrm{Pb}$ e $\mathrm{Cu}$ são os elementos que tende a ficar mais retido no solo e $\mathrm{Cd}$ e $\mathrm{Zn}$ tendem a ficar menos retidos.

Quanto aos cátions metálicos, a sorção ocorrerá mais facilmente quanto mais eletropositivo (ou menos eletronegativo) for o cátion. Numa solução contendo vários íons metálicos esses irão competir pelos sítios de sorção disponíveis e de maneira geral a afinidade de um material adsorvente do solo por um cátion metálico "livre" em solução irá aumentar conforme a tendência desse cátion em formar complexos de superfície do tipo esfera interna descrito no item 3.2.

Os processos de troca iônica podem ocorrer entre os cátions da solução do solo e a superfície da fase sólida do solo por complexação do tipo esfera externa, descrito no item 3.2, no qual os cátions presentes na solução do 
solo podem deslocar os cátions da dupla camada elétrica (FIG.4), nesse processo, os cátions de maior valência prevalecem sobre os de menor valência. A seletividade de alguns elementos com base no raio iônico foi estabelecida por SPOSITO (1989) e consta listada a seguir:

$$
\begin{gathered}
\mathrm{Cs}^{+}>\mathrm{Rb}^{+}>\mathrm{K}^{+}>\mathrm{Na}^{+}>\mathrm{Li}^{+} \\
\mathrm{Ba}^{2+}>\mathrm{Sr}^{2+}>\mathrm{Ca}^{2+}>\mathrm{Mg}^{2+} \\
\mathrm{Hg}^{2+}>\mathrm{Cd}^{2+}>\mathrm{Zn}^{2+}
\end{gathered}
$$

Em relação aos metais de transição, o raio iônico não é o único fator que rege a predição da afinidade entre o meio sólido e os cátions metálicos livres na solução, uma vez que, a configuração eletrônica representa um importante papel nos complexos metálicos desses cátions. A tendência de afinidade relativa desses cátions segue a sequência de Irwing-Williams conforme descrito a seguir (SPOSITO, 1989):

$$
\mathrm{Cu}^{2+}>\mathrm{Ni}^{2+}>\mathrm{Co}^{2+}>\mathrm{Fe}^{2+}>\mathrm{Mn}^{2+}
$$

Os metais de transição, diferentemente de outros elementos químicos que precisam de oito elétrons na última camada eletrônica para atingir uma configuração estável, precisam de 18 elétrons para preencher suas camadas eletrônicas. Esses metais possuem deficiência de elétrons nas suas camadas, o que confere a essa classe química uma grande afinidade de formar complexos com ligantes que possam compartilhar elétrons.

\subsection{Solos brasileiros}

Em regiões tropicais úmidas, ocorrem vários tipos de solos que apresentam propriedades físicas, químicas e morfológicas específicas, mas a maioria dos solos possuem propriedades em comum, como, por exemplo, composição mineralógica básica (quartzo, caulinita, óxi-hidróxidos de ferro e alumínio), grande espessura e horizontes com cores predominantemente amarela ou vermelha (TEXEIRA et al., 2009). 
De acordo com o sistema brasileiro de classificação de solos (EMBRAPA, 2006), os Latossolos e Argissolos representam a maior parte dos solos brasileiros, com $40 \%$ e $20 \%$, respectivamente, conforme exposto na FIG.7. Ocorrem em praticamente todas as regiões do país. Os Latossolos são solos bastante intemperizados, com perfil homogêneo e horizontes pouco diferenciados, desprovidos de minerais primários alteráveis. São em geral, solos ácidos e deficientes em elementos e nutrientes (TEXEIRA et al., 2009). 


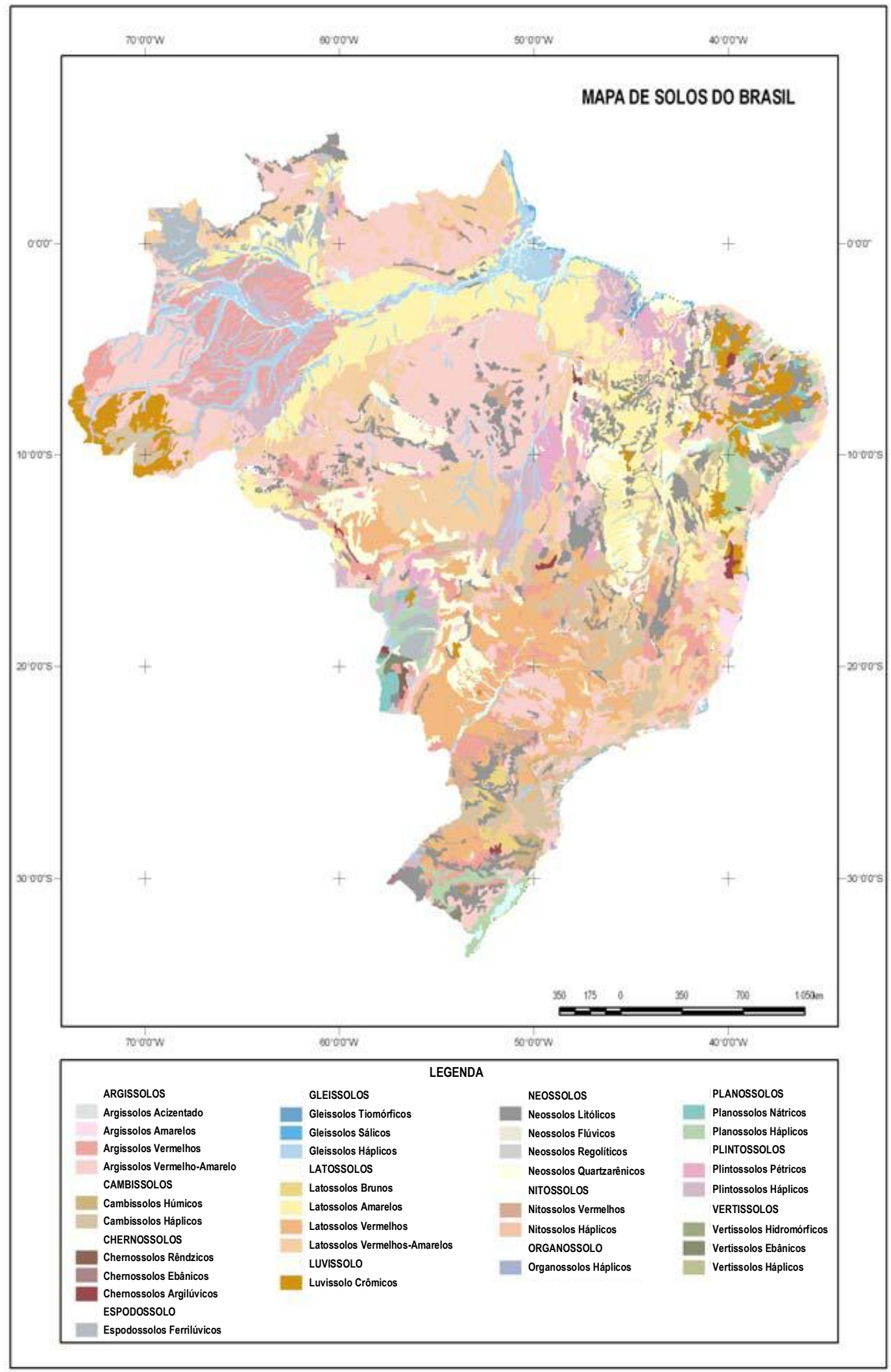

Figura 7 - Mapa de solos do Brasil atualizado segundo o atual Sistema Brasileiro de Classificação de Solos (EMBRAPA, 2006) 


\subsection{As cinzas de carvão oriundas de usinas termelétricas}

O atual estilo de vida da sociedade moderna está calcado em um consumo contínuo e ascendente de energia. Quanto mais desenvolvido o país, maior a sua demanda energética. A Organização das Nações Unidas, por exemplo, relaciona o Índice de Desenvolvimento Humano (IDH) de cada país com a capacidade dos mesmos gerarem energia (ONU, 2011).

No último século a humanidade fez uso indiscriminado de fontes não renováveis de energia, causando sérios impactos à saúde ambiental da Terra. Um dos mais importantes desafios do século XXI é suprir essa crescente demanda com fontes energéticas renováveis e mitigar a geração dos resíduos oriundos das fontes não renováveis.

É primordial aperfeiçoar o uso do carvão mineral como fonte de energia, de maneira a minimizar os impactos dessa atividade no meio ambiente, sendo esses relacionados à mineração do carvão, às emissões gasosas provenientes da combustão e à geração de resíduos sólidos que podem apresentar alta toxicidade, tais como as cinzas de carvão.

Aproximadamente $80 \%$ do resíduo sólido oriundo da combustão de carvão em usinas termelétricas são compostos de cinzas. Apesar de haver muitos estudos relacionados à utilização dessas cinzas, tais como, a aplicação na indústria de cimentos, cerâmica, concreto, filtros minerais e de asfalto, a maior fração destas cinzas ainda permanece sem destino adequado e esse é um problema mundial (DUTTA et al., 2009).

\subsubsection{Cinzas de carvão - Panorama Mundial}

De acordo com o World Coal Institute, as reservas mundiais de carvão poderiam suprir os atuais índices de consumo de energia por mais 122 anos (WCl, 2011). Outro estudo estima que essas reservas possam suprir a atual demanda energética por mais 500 anos (BP, 2010). O fato é que o carvão é atualmente o combustível fóssil mais abundante na crosta terrestre e assim sendo as perspectivas de consumo desse combustível são de longo prazo. 
China, Índia e Estados Unidos produzem juntos aproximadamente 391 milhões de toneladas de cinzas por ano (DUTTA et al., 2009).

A Alemanha produz anualmente 4,3 milhões de toneladas de cinzas leves e utiliza quase $100 \%$ em indústrias de cimento e concreto, além de outros materiais de construção, produtos cerâmicos, alvenaria, construção de estradas e outras aplicações (CAO et al., 2008).

\subsubsection{Produção de cinzas no Brasil}

A matriz energética brasileira, conforme dados da Agência Nacional de Energia Elétrica (ANEEL), tem como principal fonte de energia a hidroeletricidade $(71,34 \%)$, seguida pela termoeletricidade $(23,36 \%)$, entre outras fontes (ANEEL, 2011).

As usinas termelétricas à base de carvão mineral produzem atualmente $8 \%$ do total de energia termelétrica produzida no Brasil. De acordo com os dados da Empresa de Pesquisa Energética, esse consumo tende a aumentar, tendo em vista a ascensão do consumo energético nacional e a presença de milhares de toneladas de carvão mineral dispostos nas jazidas localizadas no sul do país (EPE, 2011).

No Brasil as usinas termelétricas à base de carvão mineral se concentram na região Sul, devido à localização das maiores jazidas de carvão do país. As usinas termelétricas estão instaladas em cinco municípios ao todo, distribuídos nos Estados do Rio Grande do Sul, Santa Catarina e Paraná, conforme listado na TAB.10 (ROHDE et al., 2006). Estima-se que essas usinas termelétricas brasileiras gerem cerca de quatro milhões de toneladas por ano de cinzas de carvão, das quais somente $50 \%$ são aproveitadas (ROHDE et al., 2006). 
TABELA 10 - Usinas termelétricas em operação no Brasil

\begin{tabular}{ccc}
\hline Usina termelétrica & Localização & Potência (MW) \\
\hline Presidente Médici & Candiota (RS) & 446 \\
São Jerônimo & São Jerônimo (RS) & 20 \\
Jorge Lacerda & Capivari de Baixo (SC) & 857 \\
Charqueadas & Charqueadas (RS) & 72 \\
Figueira & Figueira (PR) & 20 \\
\hline
\end{tabular}

Fonte: ROHDE et al. (2006)

Devido à necessidade de ampliar a matriz energética brasileira, o Plano Nacional de Energia (PNE 2030) prevê o aumento da geração de energia por meio do uso de usinas termelétricas de carvão mineral no Sul do Brasil para 4600 MW (EPE, 2011) e, consequentemente, maiores quantidades de cinzas de carvão serão geradas.

\subsubsection{Tipos de cinzas geradas nas usinas termelétricas brasileiras}

Durante o processo de combustão de carvão nas usinas termelétricas são gerados três tipos principais de resíduos sólidos, sendo esses classificados como escória, cinza de fundo e cinzas leves ou volantes (ROHDE et al., 2006).

A escória é um material grosseiro que se apresenta em blocos sinterizados e fica retido em grelhas fixas ou móveis da usina.

A cinza de fundo é a que possui maior peso e granulometria quando comparada com as outras cinzas e por isso não consegue ser arrastada pelo filtro ciclone nas caldeiras de vapor, ficando depositada no fundo das fornalhas e gaseificadores.

As cinzas leves ou volantes são aquelas que são arrastadas pelo filtro ciclone por apresentarem uma menor granulometria, ficando retidas nos sistemas de captação, tais como filtros ciclones mecânicos, filtros manga ou precipitadores eletrostásticos (CARVALHO, 2010; IZIDORO, 2008). Uma pequena porção dessas cinzas, de granulometria extremamente fina, é liberada para a atmosfera.

Dos três tipos de resíduos apresentados, as cinzas leves são as de maior preocupação ambiental. A concentração de elementos tóxicos nas cinzas 
leves quando comparada com à de cinzas de fundo é mais elevada e ainda mais biodisponível (CAMARGO, 2005).

\subsubsection{Composição das cinzas de carvão brasileiras}

Não há no Brasil uma legislação específica para tratar das cinzas de carvão e por isso devem ser classificadas de acordo com a norma NBR 10004 da Associação Brasileira de Normas Técnicas (ABNT) que classifica os resíduos sólidos (ABNT, 2004). Devido a sua composição química as cinzas brasileiras são classificadas em grande maioria como resíduos Classe II - A - não perigoso e não inerte (ROHDE et al., 2006) e devem ser dispostas em aterros sanitários.

Na TAB.11 foram apresentadas as concentrações de elementos traços nas cinzas volantes geradas nos cinco municípios brasileiros (DEPOI et al., 2008). 
TABELA 11 - Concentração em $\mathrm{mg} \mathrm{kg}^{-1}$ dos elementos traços nas cinzas volantes de carvão brasileiras

\begin{tabular}{|c|c|c|c|c|c|}
\hline & Charqueada/RS & Candiota/RS & São Jerônimo/RS & Capivari de Baixo/SC & Figueira/PR \\
\hline $\mathrm{Ag}$ & 2,24 & 1,67 & 2,21 & 5,21 & 10,1 \\
\hline As & 35,6 & 11,9 & 20,9 & 37,2 & 1820 \\
\hline $\mathrm{Au}$ & 0,14 & 0,09 & 0,08 & 0,10 & 0,08 \\
\hline B & 190 & 168 & 247 & 114 & 123 \\
\hline $\mathrm{Ba}$ & 296 & 372 & 164 & 443 & 660 \\
\hline $\mathrm{Be}$ & 6,58 & 3,27 & 12,9 & 3,41 & 6,67 \\
\hline $\mathrm{Cd}$ & 0,77 & 0,55 & 0,41 & 1,32 & 16,4 \\
\hline $\mathrm{Ce}$ & 107 & 106 & 64,4 & 124 & 224 \\
\hline Co & 12,6 & 13,9 & 10,9 & 10,7 & 18,1 \\
\hline $\mathrm{Cr}$ & 82,1 & 41,8 & 88,6 & 98,2 & 111 \\
\hline $\mathrm{Cu}$ & 29,1 & 20,7 & 36,8 & 32,2 & 52,6 \\
\hline $\mathrm{Ga}$ & 35,9 & 20,1 & 24,3 & 26,7 & 27,4 \\
\hline $\mathrm{Ge}$ & 14,7 & 1,64 & 11,1 & 8,97 & 41,8 \\
\hline $\mathrm{Li}$ & 96,7 & 36,3 & 90,5 & 76,0 & 107 \\
\hline $\mathrm{Mn}$ & 66,1 & 294 & 78,1 & 155 & 305 \\
\hline Mo & 4,95 & 3,93 & 4,88 & 5,65 & 385 \\
\hline $\mathrm{Nb}$ & 18,6 & 13,4 & 15,8 & 16,7 & 11,1 \\
\hline $\mathrm{Ni}$ & 37,1 & 27,1 & 38,7 & 32,3 & 51,7 \\
\hline $\mathrm{Pb}$ & 57,3 & 26,2 & 44,1 & 52,7 & 3477 \\
\hline $\mathrm{Pt}$ & 0,10 & 0,07 & 0,04 & 0,12 & 0,11 \\
\hline $\mathrm{Rb}$ & 59,8 & 107 & 32,5 & 84,3 & 92,0 \\
\hline $\mathrm{Sb}$ & 2,19 & 1,03 & 1,42 & 1,39 & 7,38 \\
\hline $\mathrm{Se}$ & 3,57 & 0,49 & 3,16 & 3,67 & 11,4 \\
\hline $\mathrm{Sr}$ & 107 & 88,4 & 48,1 & 91,1 & 466 \\
\hline $\mathrm{TI}$ & 2,25 & 1,67 & 2,32 & 3,74 & 29,7 \\
\hline$U$ & 8,45 & 5,65 & 6,37 & 11,8 & 609 \\
\hline V & 171 & 89,1 & 166 & 198 & 231 \\
\hline $\mathrm{Zn}$ & 134 & 83,6 & 108 & 222 & 2224 \\
\hline $\mathrm{Zr}$ & 110 & 112 & 139 & 291 & 633 \\
\hline$Y$ & 55,9 & 52,0 & 50,1 & 55,0 & 169 \\
\hline $\mathrm{Hg}$ & 0,11 & 0,01 & $<0,007$ & 0,16 & 1,22 \\
\hline
\end{tabular}

As cinzas volantes geradas na usina termelétrica de Figueira no Estado do Paraná apresentam concentrações mais elevadas de alguns elementos tóxicos como antimônio, arsênio, bário, cádmio, zinco, chumbo e molibdênio quando comparadas com as cinzas de outros municípios (TAB.11). A disposição inadequada dessas cinzas sobre o solo pode acarretar a lixiviação de elementos tóxicos para a água subterrânea e apresentar risco a saúde humana dependendo da concentração desses elementos no solo e na água subterrânea.

No Sul do Brasil, onde essas cinzas são geradas, é possível identificar severos danos causados ao meio ambiente, decorrentes da deposição inadequada desse resíduo, tais como assoreamento de rios, contaminação fluvial via escoamento superficial, contaminação de águas subterrâneas via lixiviação e 
contato do resíduo com criações de animais e plantações de diversas culturas (ROHDE et al., 2006).

\subsection{Toxicidade dos elementos As, Cd, Mo, $\mathrm{Pb}$ e $\mathrm{Zn}$}

Existem muitos elementos que são considerados como micro e macronutrientes essenciais para a manutenção da saúde humana ou de outros organismos vivos, e existem elementos não essenciais que não causam problemas à saúde de organismos vivos quando não consumidos (SIEGEL, 2002). Quando há um consumo de um elemento não essencial ou um consumo excessivo de elementos essenciais, ao longo do tempo, um organismo pode desenvolver uma condição adversa, doenças ou até mesmo morrer.

Na TAB.12 foi apresentada a toxicidade, essencialidade e os valores de intervenção na água e no solo para os elementos As, Cd, Mo, $\mathrm{Pb}$ e $\mathrm{Zn}$.

TABELA 12 - Toxicidade dos elementos, essencialidade dos elementos em organismos vivos e valores de intervenção dos elementos no solo e água subterrânea

\begin{tabular}{|c|c|c|c|c|c|}
\hline \multirow[b]{2}{*}{ Elemento } & \multicolumn{2}{|c|}{ Toxicidade } & \multirow{2}{*}{$\begin{array}{l}\text { Essencialidade } \\
\text { em organismos } \\
\text { vivos }\end{array}$} & \multicolumn{2}{|c|}{ Valores de Intervenção } \\
\hline & Plantas & Mamíferos & & $\begin{array}{l}\text { Solo (agrícola) } \\
\left(\mathrm{mg} \mathrm{kg}^{-1}\right)\end{array}$ & $\begin{array}{l}\text { Água subterrânea } \\
\qquad\left(\mu \mathrm{g} \mathrm{L}^{-1}\right)\end{array}$ \\
\hline As & $\mathrm{M} / \mathrm{A}$ & A & Essencial & 35 & 10 \\
\hline $\mathrm{Cd}$ & $\mathrm{M} / \mathrm{A}$ & $A$ & Não essencial & 3 & 5 \\
\hline Mo & $\mathrm{M}$ & M & Essencial & 50 & 70 \\
\hline $\mathrm{Pb}$ & $\mathrm{M}$ & $A$ & Não essencial & 168 & 10 \\
\hline $\mathrm{Zn}$ & $\mathrm{B} / \mathrm{M}$ & $\mathrm{B} / \mathrm{M}$ & Essencial & 450 & 5000 \\
\hline
\end{tabular}

Os valores de intervenção estabelecidos pela CETESB (2005) para solo e água subterrânea listados na TAB.12 representam a concentração no solo ou na água subterrânea acima da qual existem riscos potenciais, diretos ou indiretos, à saúde humana, para cenários de exposição agrícola, considerado como área de proteção máxima.

Existem três principais vias de exposição dos receptores aos elementos tóxicos no meio ambiente. A primeira é a via atmosférica direta, ou indireta por deposição no solo e na água. A segunda é a água, usada para consumo direto, para irrigação de plantações e para consumo de criações de 
animais. A terceira é via cadeia alimentar por contaminação dos organismos da fauna e flora presentes na atmosfera, solo e água (SIEGEL, 2002).

\subsection{Espécies químicas dos elementos $\mathrm{As}, \mathrm{Cd}, \mathrm{Mo}, \mathrm{Pb}$ e $\mathrm{Zn}$ no solo}

Um elemento pode apresentar diferentes mobilidades e toxicidades dependendo da espécie química dele no solo. As espécies químicas dos elementos tóxicos $\mathrm{As}, \mathrm{Cd}$, Mo, $\mathrm{Pb}$ e $\mathrm{Zn}$ no solo foram abordadas nos itens a seguir.

\subsubsection{Arsênio}

Os estados de oxidação de As mais comuns em solos são As(III) e As $(\mathrm{V})$. A toxicidade do arsênio está diretamente relacionada com a espécie química desse elemento e seu estado de oxidação. No solo, esse elemento pode ocorrer em diversas formas químicas, tais como compostos inorgânicos e orgânicos.

De acordo com BARRA et al. (2000), o As trivalente (arsenito) é 60 vezes mais tóxico do que a forma oxidada pentavalente (arsenato). Segundo os mesmos autores, os compostos inorgânicos são 100 vezes mais tóxicos do que as formas parcialmente metiladas.

As espécies inorgânicas de As em solo são majoritariamente oxiânions que podem apresentar diferentes valências e número de prótons. $O$ arsenito $\left(\mathrm{As}^{3+}\right)$ pode ser encontrado como $\mathrm{H}_{3} \mathrm{AsO}_{3}, \mathrm{H}_{2} \mathrm{AsO}_{3}{ }^{-}, \mathrm{HAsO}_{3}{ }^{2-}$ e $\mathrm{AsO}_{3}{ }^{3-}$ e o arsenato $\left(\mathrm{As}^{5+}\right.$ ) como $\mathrm{H}_{3} \mathrm{AsO}_{4}, \mathrm{H}_{2} \mathrm{AsO}_{4}{ }^{-}, \mathrm{HAsO}_{4}{ }^{2-}$ e $\mathrm{AsO}_{4}{ }^{3-}$ (SELIM e SPARKS, 2001). A distribuição dessas espécies depende majoritariamente do $\mathrm{pH}$ e do potencial redox do solo. De acordo com ALLOWAY (1990), em solos ácidos prevalece a espécie $\mathrm{H}_{2} \mathrm{AsO}_{4}{ }^{-}$e em solos alcalinos a espécie $\mathrm{HAsO}_{4}{ }^{2-}$.

As formas orgânicas de As em solo estão relacionadas com reações de metilação ocasionadas por micro-organismos (SELIM e SPARKS, 2001). As formas mais comuns de $\mathrm{As}(\mathrm{V})$ são ácido monometilarsônico (MMAA), e ácido dimetilarsínico (DMAA). Para As(III) são ácido monometilarsenioso (MMA) e dimetilarsenioso (DMA) (HUGHES, 2002). 


\subsubsection{Cádmio}

O cádmio é encontrado majoritariamente no solo como íon solúvel $\mathrm{Cd}^{2+}$, mas espécies de $\mathrm{Cd}$ associadas a compostos orgânicos e inorgânicos também podem ocorrer (PROKOP et al., 2003, HOLM et al., 1994). Entretanto, de acordo com KRISHNAMURT e NADU (2003) as espécies orgânicas solúveis de Cd predominam na solução do solo, sendo que a maior concentração dessas espécies é encontrada em solos ácidos. YONG e MULLIGAN (2004) relatouram que é possível encontrar o $\mathrm{Cd}$ no solo na forma de complexos orgânicos e inorgânicos solúveis como aminas, cianetos e haletos, e que essas espécies aumentam a mobilidade desse elemento em solos.

As propriedades químicas do $\mathrm{Cd}$ são similares as do $\mathrm{Zn}$, porém o $\mathrm{Cd}$ é mais móvel que $\mathrm{Zn}$ em solos mais ácidos, particularmente em pH entre 4,5 e 5,5 e sua mobilidade é reduzida em $\mathrm{pH}>7,5$ (YONG e MULLIGAN, 2004). De acordo com ALLOWAY (1990) em solos ácidos prevalecem as espécies $\mathrm{Cd}^{2+}, \mathrm{CdSO}_{4}{ }^{0}$, $\mathrm{CdCl}^{+}$e em solos alcalinos as espécies $\mathrm{Cd}^{2+}, \mathrm{CdSO}_{4}{ }^{0}, \mathrm{CdCl}^{+}$e $\mathrm{CdH}$-complexo orgânico.

O Cd pode representar grande preocupação ambiental, pois não é essencial para organismos vivos, mas por ser bivalente como outros elementos que são essenciais, tais como, $\mathrm{Zn}, \mathrm{Mg}$ e $\mathrm{Ca}$, o $\mathrm{Cd}$ pode se acumular em organismos vivos.

\subsubsection{Chumbo}

Geralmente, o chumbo em solo não representa um problema ambiental até que esteja na forma iônica e dissolvido em solução. A mobilidade de chumbo em solo é relativamente baixa, devido alta afinidade desse elemento com a matéria orgânica e óxidos de Mn (McBRIDE, 1994).

De acordo com ALLOWAY (1990) em solos ácidos prevalecem as espécies $\mathrm{Pb}^{2+}, \mathrm{PbSO}_{4}{ }^{0}$, complexos orgânicos, $\mathrm{PbHCO}_{3}{ }^{+} \mathrm{e}$ em solos alcalinos as espécies $\mathrm{PbCO}_{3}{ }^{0}, \mathrm{PbHCO}_{3}{ }^{+}, \mathrm{Pb}\left(\mathrm{CO}_{3}\right)_{2}{ }^{2-}$ e $\mathrm{PbOH}^{+}$. 


\subsubsection{Molibdênio}

O estado de oxidação de Mo mais comum em solos é +6 e as espécies inorgânicas de Mo em solo são majoritariamente oxiânions que podem apresentar diferentes números de prótons. As formas orgânicas de Mo no solo estão associadas aos polifenóis presentes nas substâncias húmicas (McBRIDE, 1994).

De acordo com ALLOWAY (1990) em solos ácidos prevalecem as espécies $\mathrm{H}_{2} \mathrm{MoO}_{4}{ }^{0}, \mathrm{HMoO}_{4}{ }^{-}$e em solos alcalinos as espécies $\mathrm{HMoO}_{4}{ }^{-}$e $\mathrm{MoO}_{4}{ }^{2-}$.

A mobilidade de Mo em solo é moderada em solos ácidos, devido à afinidade desse elemento com os óxidos de $\mathrm{Fe}$, e alta em solos neutros ou alcalinos (McBRIDE, 1994).

\subsubsection{Zinco}

Em solos ácidos predomina a ocorrência de $\mathrm{Zn}$ como cátion livre $\left(\mathrm{Zn}^{2+}\right)$ que é considerado como um dos cátions bivalentes mais solúveis e móveis presentes em solos. Por isso é considerado como um dos elementos que apresenta alta fitotoxicidade (McBRIDE, 1994). Em solos fortemente alcalinos a mobilidade de $\mathrm{Zn}$ também é elevada devido à associação com a matéria orgânica solúvel (YONG e MULLIGAN, 2004).

De acordo com ALLOWAY (1990) em solos ácidos prevalecem as espécies $\mathrm{Zn}^{2+}, \mathrm{ZnSO}_{4}{ }^{0}$ e em solos alcalinos as espécies $\mathrm{Zn}^{2+}, \mathrm{ZnCO}_{3}{ }^{0}, \mathrm{ZnHCO}_{3}{ }^{+} \mathrm{e}$ $\mathrm{ZnB}(\mathrm{OH})_{4}^{+}$.

\subsection{Estudos em colunas de solo}

Geralmente, em estudos com colunas de solo, o solo é acondicionado em colunas confeccionadas de materiais preferencialmente inertes, podendo este solo já estar contaminado ou ainda ser contaminado ao longo do experimento pela adição de um determinado resíduo ou de uma solução composta de elementos tóxicos no topo da coluna de solo, ou ainda o solo pode ser misturado com o resíduo antes de ser acondicionado na coluna. As colunas são então lixiviadas com uma solução em sistemas abertos ou totalmente fechados. Após o 
período de lixiviação as colunas de solo são desmontadas com a finalidade de se analisar o incremento do elemento tóxico no solo, bem como no percolado gerado por essa lixiviação.

Em estudos de colunas de solo em laboratório é possível controlar variáveis como, tempo, proporção solo:resíduo, volume de lixiviação, temperatura, camada do perfil do solo a ser utilizada, entre outros fatores. Embora existam incertezas nos estudos de colunas de solo, os dados obtidos nesses estudos podem indicar o comportamento dos elementos tóxicos nos solos auxiliando na remediação de solos contaminados e retardando ou evitando a contaminação da água subterrânea.

Diversos autores têm estudado a mobilidade de elementos tóxicos em solos por meio de experimentos em colunas, conforme alguns trabalhos listados na TAB.13. 
TABELA 13 - Exemplos de estudos da mobilidade de elementos tóxicos por meio de experimentos em colunas de solos

\begin{tabular}{|c|c|c|c|c|c|c|}
\hline Solo & $\begin{array}{c}\text { Fonte } \\
\text { contaminadora }\end{array}$ & $\begin{array}{l}\text { Elemento } \\
\text { estudado }\end{array}$ & $\begin{array}{l}\text { Solução de } \\
\text { lixiviação }\end{array}$ & $\begin{array}{l}\text { Tempo de } \\
\text { lixiviação }\end{array}$ & $\begin{array}{l}\text { Tipo de } \\
\text { coluna }\end{array}$ & Referência \\
\hline $\begin{array}{l}\text { Estrangeiro } \\
\text { Franco } \\
(\mathrm{pH} \sim 6,0)\end{array}$ & Solo contaminado & $\begin{array}{c}\text { As, } \mathrm{Cde} \\
\mathrm{Zn}\end{array}$ & Água deionizada & 63 dias & Deformada & $\begin{array}{l}\text { BEESLEY } \\
\text { et al. (2010) }\end{array}$ \\
\hline $\begin{array}{l}\text { Estrangeiro } \\
\text { Calcário } \\
(\mathrm{pH} \sim 7,5)\end{array}$ & $\begin{array}{l}\text { Solução de sais } \\
\text { dos elementos } \\
\text { estudados }\end{array}$ & $\begin{array}{c}\mathrm{Cd}, \mathrm{Cu}, \mathrm{Pb} \\
\text { e } \mathrm{Zn}\end{array}$ & Água de irrigação & 81 dias & Indeformada & $\begin{array}{l}\text { SAYYAD et } \\
\text { al., } 2010\end{array}$ \\
\hline $\begin{array}{l}\text { Estrangeiro } \\
\text { argilo-siltoso } \\
(\mathrm{pH} 7,5)\end{array}$ & $\begin{array}{l}\text { Solução de sais } \\
\text { dos elementos } \\
\text { estudados }\end{array}$ & $\begin{array}{c}\mathrm{Cd}, \mathrm{Pb} \text { e } \\
\mathrm{Cr}\end{array}$ & Água deionizada & $\begin{array}{c}\text { Não } \\
\text { especificado }\end{array}$ & Deformada & $\begin{array}{l}\text { DONG et al. } \\
(2009)\end{array}$ \\
\hline $\begin{array}{l}\text { Estrangeiro } \\
\text { Argilo-arenoso } \\
(\mathrm{pH}=7,7)\end{array}$ & Solo contaminado & $\mathrm{Zn}$ e $\mathrm{Pb}$ & $\begin{array}{l}\text { Solução 1: EDTA } \\
\qquad(\mathrm{pH}=7) \\
\text { Solução 2: Ácido } \\
\text { acético }(\mathrm{pH}=5)\end{array}$ & $\begin{array}{c}\text { Não } \\
\text { especificado }\end{array}$ & Deformada & $\begin{array}{l}\text { HANNA et al. } \\
\qquad(2009)\end{array}$ \\
\hline $\begin{array}{l}\text { Estrangeiro } \\
\text { Franco-siltoso } \\
(\mathrm{pH}=7,7)\end{array}$ & Solo contaminado & $\begin{array}{c}\mathrm{Cd}, \mathrm{Cu}, \mathrm{Pb} \\
\text { e } \mathrm{Zn}\end{array}$ & EDTA & 24 horas & Deformada & $\begin{array}{l}\text { XIA et al. } \\
\text { (2009) }\end{array}$ \\
\hline $\begin{array}{l}\text { Estrangeiro } \\
\text { Arenoso } \\
(\mathrm{pH}=7,1)\end{array}$ & Herbicida & As & Água deionizada & 30 dias & Deformada & $\begin{array}{l}\text { YUE et al. } \\
\text { (2009) }\end{array}$ \\
\hline $\begin{array}{l}\text { Estrangeiro } \\
\text { Solos neutros a } \\
\text { alcalinos }\end{array}$ & $\begin{array}{c}\text { Solos } \\
\text { contaminados e } \\
\text { tratados com } \\
\text { óxido de ferro }\end{array}$ & As & $\begin{array}{l}\text { Água deionizada } \\
\text { acidificada com } \\
\mathrm{HNO}_{3}(\mathrm{pH}=4)\end{array}$ & 3 semanas & Deformada & $\begin{array}{l}\text { HARTLEY et } \\
\text { al. (2004) }\end{array}$ \\
\hline $\begin{array}{l}\text { Estrangeiro } \\
\text { Solo laterítico } \\
(\mathrm{pH}=3,9)\end{array}$ & $\begin{array}{c}\text { Cinza leve de } \\
\text { carvão }\end{array}$ & $\begin{array}{c}\mathrm{Cu}, \mathrm{Pb}, \\
\mathrm{Zn}, \mathrm{Mn}, \\
\mathrm{Fe}, \mathrm{Cr}, \mathrm{Ni}, \\
\mathrm{Cd}, \mathrm{Hg}, \mathrm{Al}, \\
\mathrm{Ca}, \mathrm{Mg}, \\
\mathrm{Na} \text { e K }\end{array}$ & Água & 8 dias & Deformada & $\begin{array}{c}\text { GOSWANI e } \\
\text { MAHANTA } \\
(2007)\end{array}$ \\
\hline $\begin{array}{l}\text { Brasileiro } \\
\text { Franco-arenoso } \\
(\mathrm{pH} \sim 4)\end{array}$ & Pilhas alcalinas & $\mathrm{Zn}$ e $\mathrm{Mn}$ & $\begin{array}{c}\text { Agua acidificada } \\
\text { com } \mathrm{HNO}_{3} \text { e } \\
\mathrm{H}_{2} \mathrm{SO}_{4}(\mathrm{pH}=4)\end{array}$ & 336 dias & Indeformada & $\begin{array}{l}\text { AGOURAKIS } \\
\text { et al. (2006) }\end{array}$ \\
\hline $\begin{array}{l}\text { Brasileiro } \\
\text { Franco argilo } \\
\text { arenoso ( } \mathrm{pH} \sim 4)\end{array}$ & $\begin{array}{c}\text { Pilhas zinco- } \\
\text { carbono }\end{array}$ & $\begin{array}{c}\mathrm{Zn}, \mathrm{Mn}, \\
\mathrm{Pb}, \mathrm{Cr}, \mathrm{Cu}, \\
\text { Ni e Cd }\end{array}$ & $\begin{array}{c}\text { Agua acidificada } \\
\text { com } \mathrm{HNO}_{3} \mathrm{e} \\
\mathrm{H}_{2} \mathrm{SO}_{4}(\mathrm{pH}=4)\end{array}$ & 336 dias & Indeformada & $\begin{array}{c}\text { GAZANO } \\
(2006)\end{array}$ \\
\hline $\begin{array}{l}\text { Brasileiro } \\
(\mathrm{pH} \sim 4)\end{array}$ & $\begin{array}{l}\text { Lodo de estação } \\
\text { de tratamento de } \\
\text { esgosto }\end{array}$ & $\begin{array}{c}\mathrm{Cu}, \mathrm{Pb} \text { e } \\
\mathrm{Ni}\end{array}$ & Água deionizada & 60 dias & Indeformada & $\begin{array}{l}\text { CORNU et al. } \\
\qquad(2001)\end{array}$ \\
\hline
\end{tabular}

Com base na TAB.13 é possível destacar que as colunas preenchidas com amostras deformadas foram mais amplamente aplicadas nos estudos de 
colunas de solo, bem como, o tempo de lixiviação para a maioria dos estudos foi inferior a 90 dias, exceto nos estudos realizados por AGOURAKIS et al. (2006) e GAZANO (2006), nos quais as colunas por 336 dias. Entretanto, esses autores realizaram seus estudos no mesmo grupo de pesquisa no qual o presente estudo foi desenvolvido.

Até o presente momento, no levantamento bibliográfico não foi constatado estudos de colunas de solos brasileiros com cinza de carvão. Foi levantado apenas um estudo com solo estrangeiro e cinza de carvão realizado por GOSWANI e MAHANTA (2007). 


\section{METODOLOGIA}

Para avaliar o comportamento de elementos tóxicos presentes na cinza de carvão em um solo, foram conduzidos ensaios de lixiviação de colunas de solo e cinza em condições de laboratório, nos quais a cinza foi colocada sobre o solo acondicionado em colunas de acrílico e as colunas foram lixiviadas por um período de 336 dias.

\subsection{Cinza de carvão}

A cinza leve de carvão foi composta por uma mistura de lotes provenientes do filtro manga do processo de combustão do carvão da usina termelétrica de Figueira, no Estado do Paraná, coletados num período de 12 meses, entre 2001 e 2002, de dois em dois meses, totalizando seis lotes. A cinza dessa usina e desse tipo de filtro foi selecionada para o estudo porque apresenta maior concentração de elementos tóxicos tanto quando comparada àquelas cinzas obtidas em outras usinas termelétricas brasileiras (TAB.11) como em outro filtro (ciclone) ou compartimento (fundo da caldeira) da usina (CAMARGO, 2005).

\subsection{Solo}

O solo coletado para o presente estudo foi selecionado com base na representatividade dos solos brasileiros descrita no item 3.5 e na baixa retenção dos elementos no solo, ou seja, foi selecionado um Latossolo com textura mais arenosa.

Analisando os dados de textura dos Latossolos do Estado de São Paulo obtidos por SOARES (2004) foi selecionada uma região próxima aos municípios de Araras e Conchal para a coleta do solo.

O solo foi coletado na região centro-leste do Estado de São Paulo, em maio de 2009 , tendo a seguinte coordenada geográfica: latitude $22^{\circ} 15.376 \mathrm{~S}^{\prime}$ e longitude $47^{\circ} 09.357$ WO'. O clima da região é cwa tropical de atitude, com inverno seco e ameno e verão quente e chuvoso, de acordo com a classificação de Köppen (NOGUEIROL, 2008). 
O solo da área foi classificado como Latossolo Vermelho Amarelo (LVA) (SOARES, 2004). O solo classificado como Latossolo foi selecionado pela sua representatividade no Estado de São Paulo e no Brasil como foi descrito no item 3.5.

Após a retirada da vegetação rasteira da área, foi coletada uma massa de $20 \mathrm{~kg}$ do solo, aproximadamente, na camada superficial (0-0,2m), numa área de mata nativa ou de reflorestamento antigo, ou seja, com pouca perturbação antropogênica (FIG.8). Foi coletado solo deformado e indeformado, utilizando espátulas e trado para amostra indeformada em aço inoxidável.

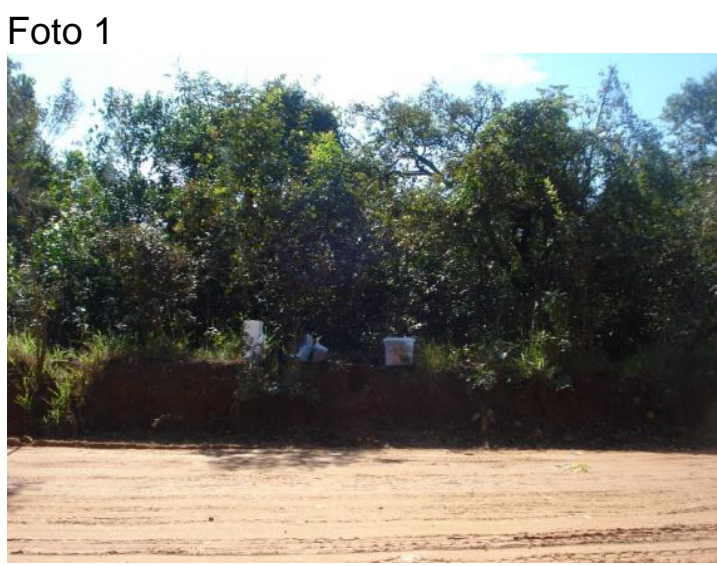

Foto 3

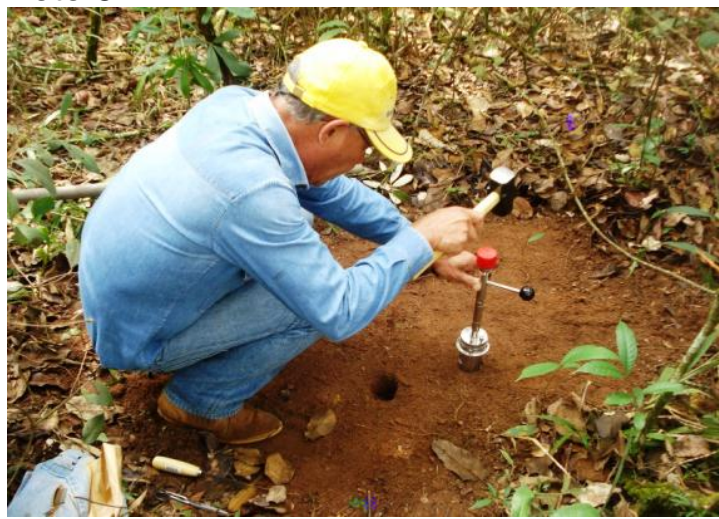

FIGURA 8 - Coleta do solo no Estado de São Paulo
Foto 2

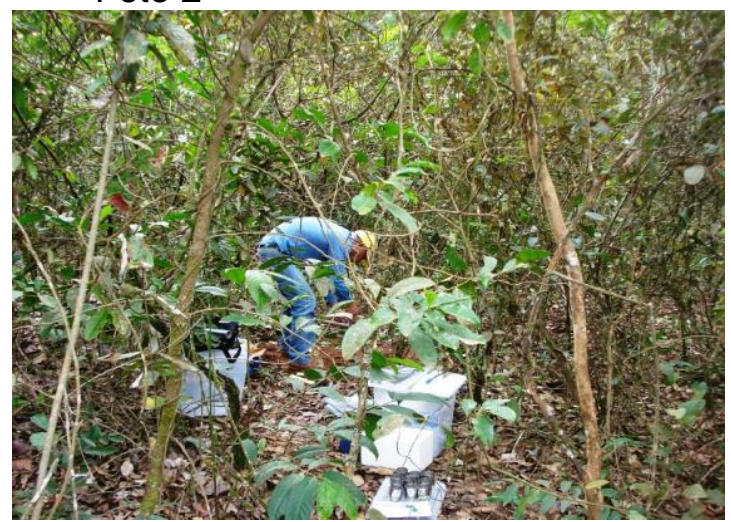

Foto 4

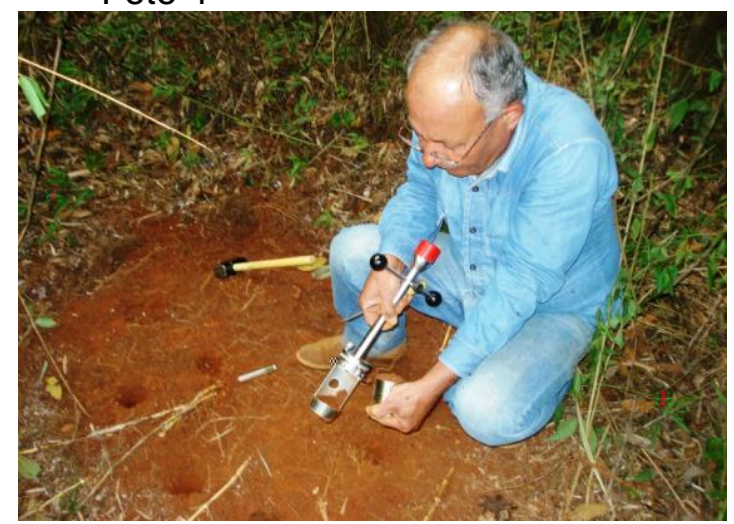

A amostra de solo deformado foi acondicionada em sacos plásticos para transporte e em seguida disposta em bandejas de plástico para secagem em temperatura ambiente. Posteriormente, os torrões maiores foram desagregados, peneirados a $2 \mathrm{~mm}$ e homogeneizados. $\mathrm{O}$ solo foi então quarteado em quarteador 
de aço inox e armazenado em frascos de plástico. As amostras de solo deformado após o tratamento descrito foram utilizadas para a montagem das colunas, e concentração dos elementos, determinação de propriedades químicas, físicas e mineralógicas.

A amostra de solo indeformado foi acondicionada em anel volumétrico de $100 \mathrm{~cm}^{3}$ de aço inoxidável durante a coleta do solo. $\mathrm{O}$ anel com o solo foi coberto com papel alumínio e armazenado em caixa térmica para transporte. As amostras de solo indeformado foram utilizadas para a determinação da densidade do solo e umidade.

\subsection{Montagem das colunas}

As colunas foram divididas em três grupos, conforme foi exposto na FIG.9.

Grupo 1

4 colunas de solo
Grupo 2

4 colunas de solo + cinza
Grupo 3:

2 colunas de cinza

\section{FIGURA 9 - Grupos de colunas}

Para montar as colunas dos grupos 1 e 2 a amostra de solo seca em temperatura ambiente, peneirada e quarteada conforme descrito no item 4.2 foi umedecida para simular a densidade e umidade de campo. Sendo assim, foram determinadas a umidade do solo coletado em campo (umidade atual) e a umidade residual, cujos métodos serão descritos na TAB.15 do item 4.7.2, para cálculo da massa de água que foi adicionada na massa de solo seco à temperatura ambiente.

O solo após atingir aproximadamente a umidade de campo, foi compactado na densidade de campo em coluna de acrílico numa altura de $5 \mathrm{~cm}$ e $8 \mathrm{~cm}$ de diâmetro utilizando uma prensa manual CBR segundo procedimento adotado pelo Laboratório de Solos da Engenharia Civil da Universidade de São Paulo (FIG.10). 

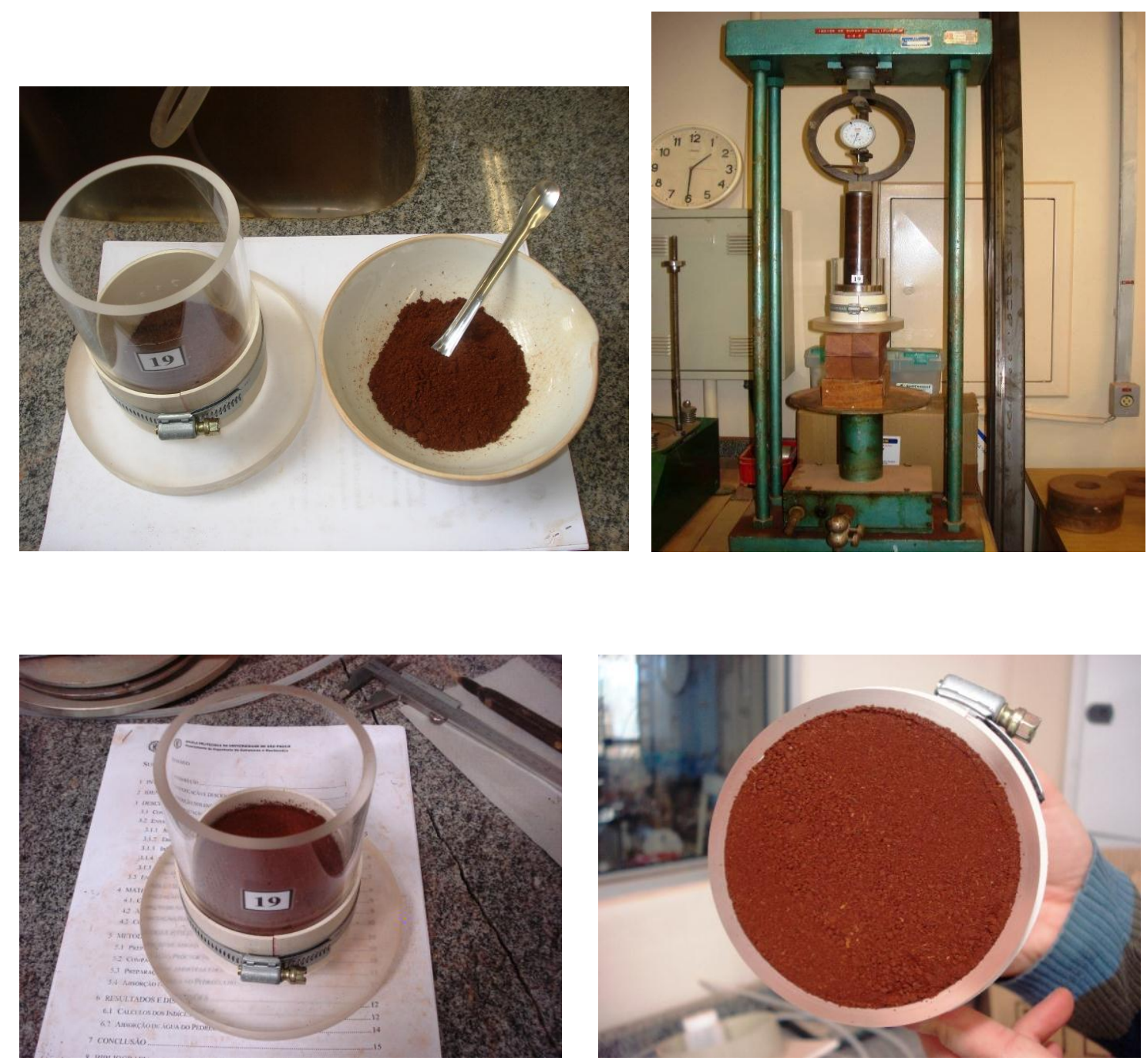

FIGURA 10 - Montagem das colunas de solo

Para calcular a massa adicionada de solo na coluna de acrílico foram utilizadas as equações 5 e 6 :

$\rho d=\frac{\rho}{1+w}$

Em que: $\rho_{d}$ é a massa específica seca; $\rho$ é a massa específica; $w$ é a umidade após adição de água.

$\rho=\frac{m}{V}$ 
Em que: $m$ é a massa de solo a ser adicionada na coluna de acrílico; $V$ é o volume ocupado pelo solo na coluna de acrílico.

Inserindo a equação 6 na 5 tem-se a massa de solo a ser adicionada na coluna de acrílico (equação 7):

$m=\rho d . V \cdot(1+w)$

Sendo assim, as propriedades de massa específica seca (densidade do solo) e umidade do solo compactado simulam estas propriedades do solo em campo.

Com base na equação 7 , a massa de solo seco adicionada nas colunas dos grupos 1 e 2 foi de $286 \mathrm{~g}$. Nesses dois grupos ( 1 e 2 ) foi colocada na base da coluna de acrílico para servir de suporte ao solo um papel de filtro qualitativo sobre um disco de polietileno com vários furos pequenos. Na superfície do solo das colunas do grupo 2 (solo+cinza) foi inserido um papel de filtro qualitativo moldado na forma de copo e dentro deste copo foram adicionados $50 \mathrm{~g}$ de cinza de carvão.

Nas colunas do grupo 3 uma camada de $5 \mathrm{~cm}$ de areia inerte, proveniente do Instituto de Pesquisas Tecnológicas (IPT), foi colocada na base da coluna de acrílico um papel de filtro qualitativo sobre um disco de polietileno com vários furos pequenos (FIG.11) para servir de suporte à cinza de carvão. $\mathrm{Na}$ superfície da areia inerte adicionada na coluna de acrílico foi inserido um papel de filtro qualitativo moldado na forma de copo e dentro deste copo foram adicionados $50 \mathrm{~g}$ de cinza de carvão nas colunas.

$\mathrm{Na}$ base das colunas de acrílico dos três grupos foi acoplado um funil de polietileno e o sistema coluna+funil foi fixado em um suporte universal. 


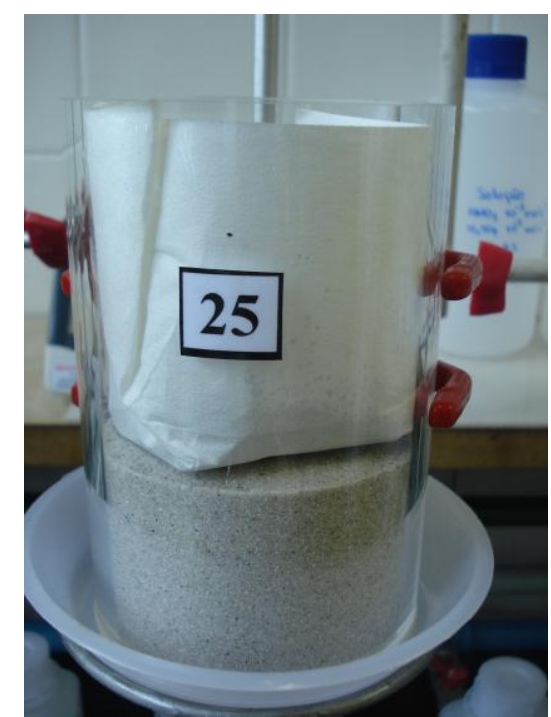

FIGURA 11 - Coluna de cinza de carvão (grupo 3)

\subsection{Lixiviação das colunas}

Em cada coluna de solo e cinza dos grupos 1, 2 e 3 descritas no item 4.3 foi colocada uma proveta de $100 \mathrm{~mL}$ na extremidade inferior do funil. $\mathrm{Na}$ extremidade superior da coluna foi colocado um frasco para nutrição enteral de $500 \mathrm{~mL}$ com uma mangueira de equipo de $2 \mathrm{~mm}$ de diâmetro fixada na tampa de acrílico da coluna, conforme apresentado na FIG.12. 

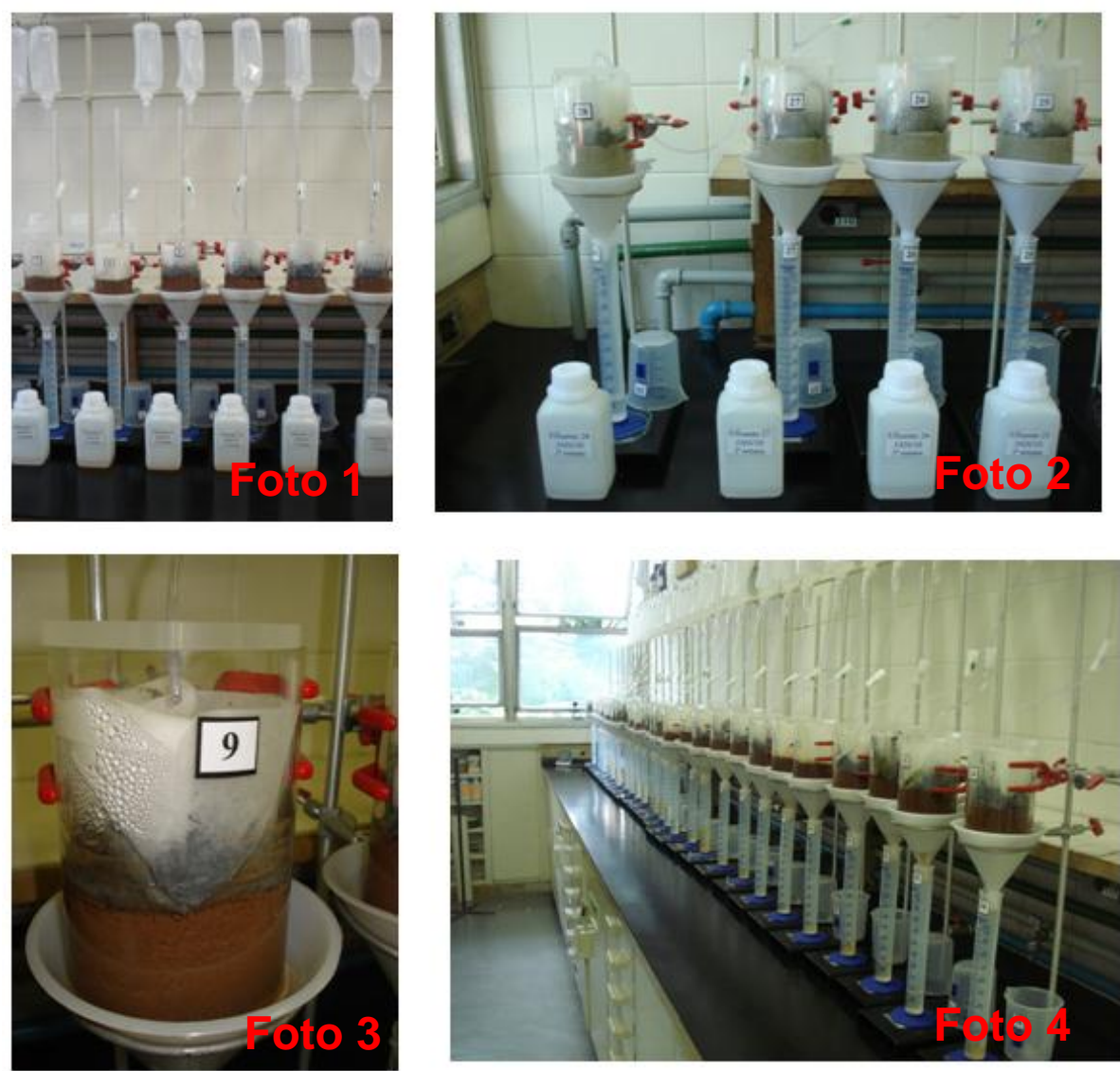

FIGURA 12 - Sistema de lixiviação das colunas de solo e colunas de cinza. Fotos 1, 3 e 4: colunas de solo. Foto 2: colunas de cinza

As colunas foram lixiviadas semanalmente com uma solução simuladora de água de chuva (solução de entrada nas colunas) de $\mathrm{pH} 4,5$, composta de $\mathrm{HNO}_{3} 10^{-5} \mathrm{~mol} \mathrm{~L}^{-1}$ e $\mathrm{H}_{2} \mathrm{SO}_{4} 10^{-5} \mathrm{~mol} \mathrm{~L}^{-1}$ misturados numa proporção 1:1, composta com base nos estudos de ROCHA et al. (2003) e FLUES et al. (2002), numa vazão de entrada da solução de 10 gotas por minuto, aproximadamente. Esta vazão foi controlada manualmente pela mangueira de equipo. Metade das colunas foram lixiviadas durante um período de 168 dias e a outra metade foi lixiviada até completar 336 dias, conforme exposto na FIG.13. 


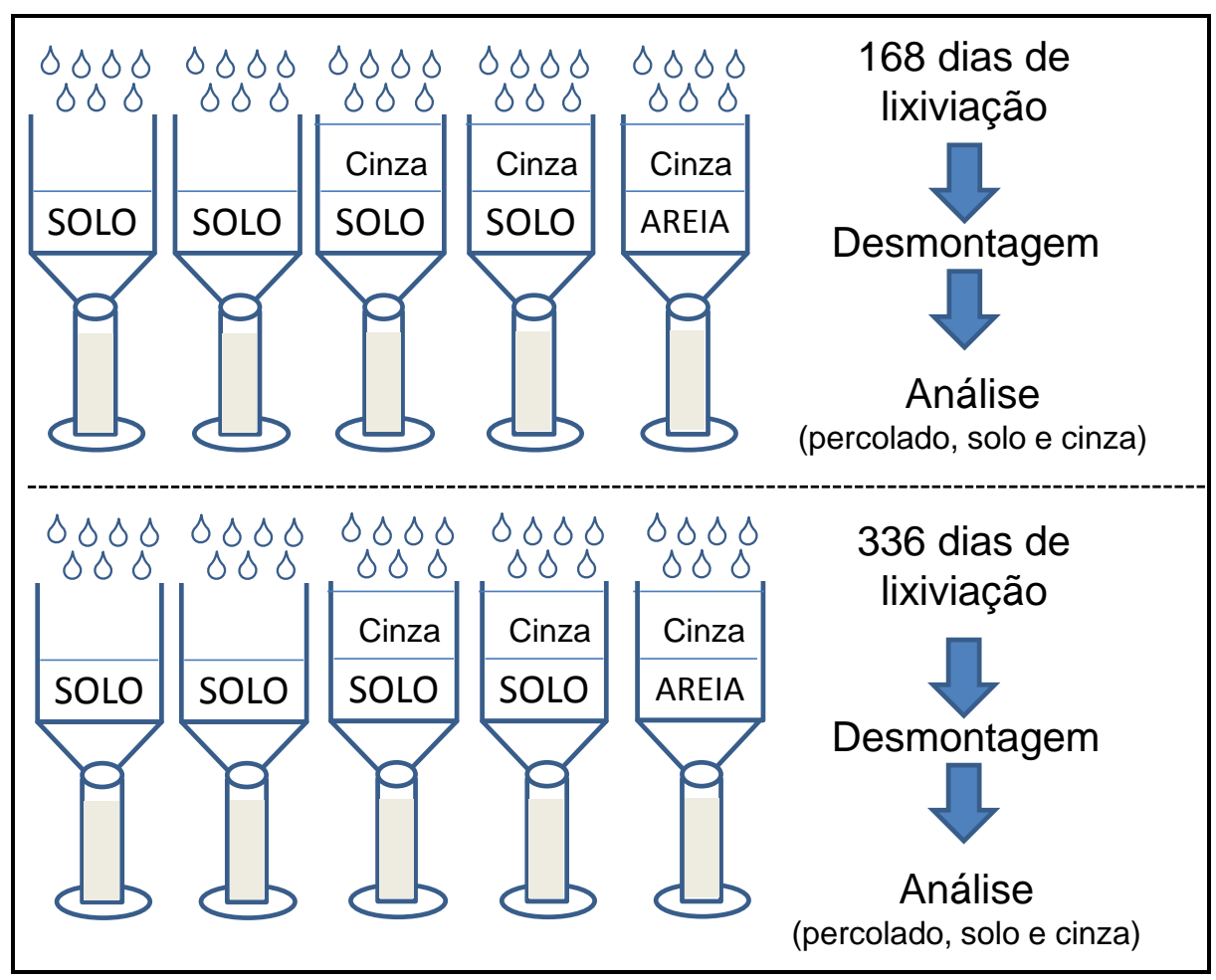

FIGURA 13 - Esquema da lixiviação das colunas

O volume da solução de entrada foi calculado com base na média do índice pluviométrico mensal entre os anos de 1933 a 2008 da cidade de São Paulo, medida pelo Instituto de Astronomia, Geofísica e Ciências Atmosféricas da Universidade de São Paulo (IAG-USP), pela equação 8:

$V=A \cdot h$

Em que: $V$ é o volume a ser adicionado em cada coluna; $A$ é a área da secção transversal da coluna de solo $\left(50,3 \mathrm{~cm}^{2}\right)$; $h$ é a média pluviométrica. $\mathrm{Na}$ TAB.14 foram apresentados os volumes da solução adicionada em cada coluna. 
TABELA 14 - Média pluviométrica mensal da cidade de São Paulo (IAG-USP) e volume da solução adicionada em cada coluna

\begin{tabular}{lccc}
\hline Mês & $\begin{array}{c}\text { Média pluviométrica } \\
\text { mensal de São Paulo } \\
\mathbf{1 9 3 3} \mathbf{- 2 0 0 8}(\mathbf{m m})\end{array}$ & $\begin{array}{c}\text { Volume a ser adicionado em } \\
\text { cada coluna por } \mathbf{m e ̂ s}(\mathbf{m L})\end{array}$ & $\begin{array}{c}\text { Volume a ser adicionado em cada } \\
\text { coluna por semana }(\mathbf{m L})\end{array}$ \\
\hline Outubro & 125 & 629 & 157 \\
Novembro & 125 & 628 & 157 \\
Dezembro & 182 & 916 & 229 \\
Janeiro & 221 & 1112 & 278 \\
Fevereiro & 207 & 1039 & 260 \\
Março & 165 & 827 & 207 \\
Abril & 81 & 405 & 101 \\
Maio & 64 & 323 & 81 \\
Junho & 50 & 252 & 63 \\
Julho & 41 & 206 & 52 \\
Agosto & 38 & 193 & 48 \\
Setembro & 76 & 384 & 96 \\
\hline
\end{tabular}

O volume mensal da solução foi dividido em quatro partes iguais e cada parte foi adicionada semanalmente nas colunas para evitar problemas com entupimento das mesmas. Sendo assim, cada coluna foi lixiviada a cada 28 dias com volume mensal da solução de outubro a setembro descrito na TAB.14. A temperatura e umidade do laboratório onde as colunas estavam dispostas foram anotadas semanalmente.

A lixiviação das colunas foi iniciada no período mais chuvoso do ano (de outubro a março), com base nos resultados de GAZANO (2006).

O percolado gerado pela lixiviação semanal das colunas foi coletado na proveta de $100 \mathrm{~mL}$, transferido para um frasco plástico e refrigerado em refrigerador a $5 \stackrel{\circ}{\circ}$, acumulando-se uma alíquota mensal para cada coluna para posterior determinação das características químicas e da concentração dos elementos.

\subsection{Determinação da vazão e do coeficiente de permeabilidade das colunas}

O volume de saída do percolado das colunas e o tempo relacionado a este volume foram registrados semanalmente medindo-se o volume e o tempo de 30 minutos a 30 minutos durante a lixiviação das colunas, com auxílio da própria 
proveta colocada abaixo do funil das colunas e de um relógio, respectivamente. A vazão foi calculada pela razão entre o volume em $\mathrm{mL}$ e o tempo em minutos.

O coeficiente de permeabilidade foi calculado com base na Lei de Darcy (PINTO, 2000) segundo a equação 9:

$Q=k . i . A$

Na qual $Q$ é a vazão da coluna, k é o coeficiente de permeabilidade, i é o gradiente hidráulico e A é a área da secção transversal da coluna. Na equação adotada no presente estudo para calcular o coeficiente de permeabilidade o gradiente hidráulico foi considerado igual a 1, ou seja, considerou-se que a perda de carga hidráulica era totalmente devida à perda de altura e a pressão neutra no sistema era nula (pressão igual à atmosférica). Observou-se que o volume de entrada de solução na coluna foi aproximadamente o mesmo volume de saída do percolado, conforme exposto na FIG.14, indicando que não houve acúmulo de percolado no topo de amostra e confirmando a hipótese de gradiente unitário.

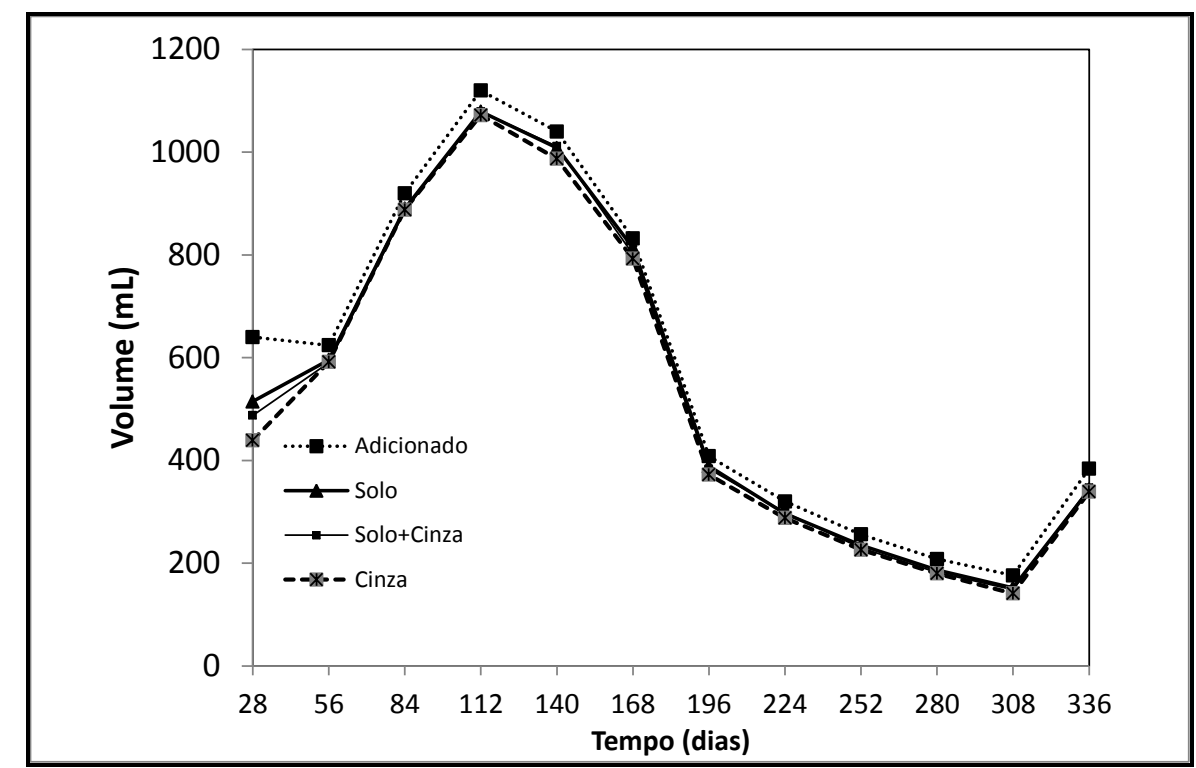

FIGURA 14 - Volume adicionado e percolado das colunas ao longo do tempo

\subsection{Desmontagem das colunas}

Após o período de lixiviação das colunas segundo o esquema da FIG.13 descrito no item 4.4, estas colunas foram desmontadas manualmente. 
A desmontagem das colunas foi ilustrada na FIG.15.

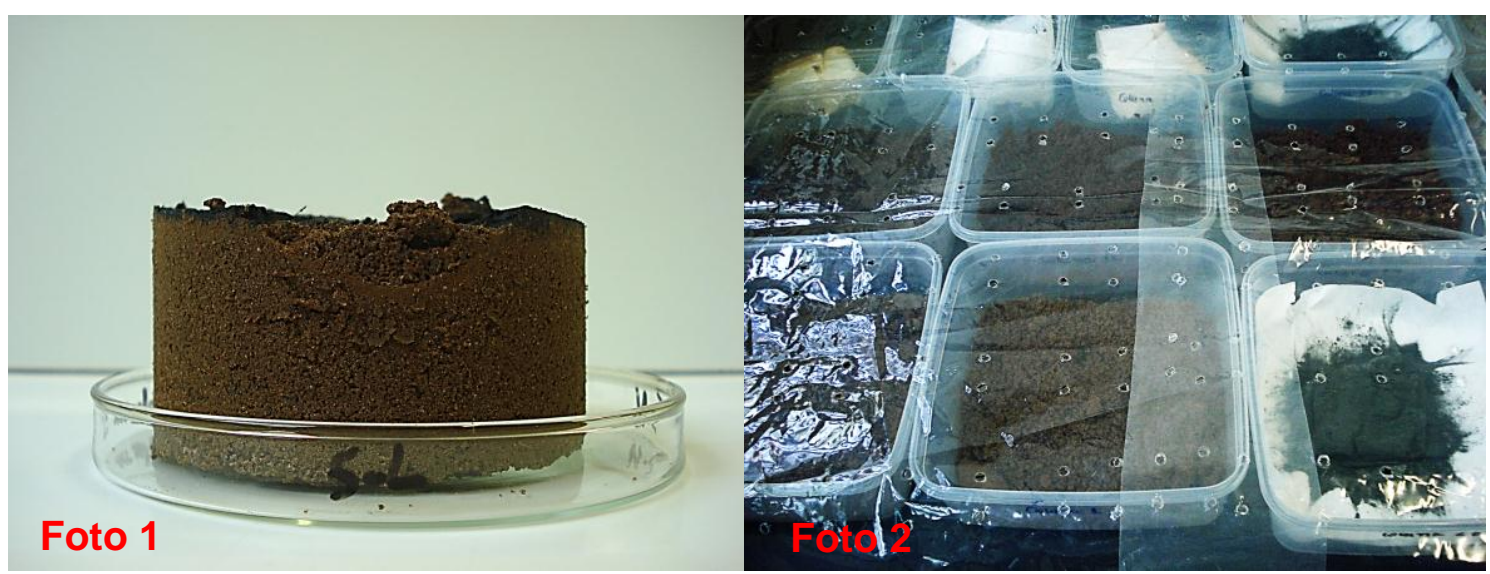

FIGURA 15 - Desmontagem das colunas. Foto 1: coluna de solo desmontada. Foto 2: solo e cinza secando a temperatura ambiente

A cinza de carvão foi retirada cuidadosamente das colunas de solo+cinza e cinza para evitar contaminação do solo. Em seguida a cinza foi seca à temperatura ambiente, pesada e homogeneizada para posterior determinação da concentração dos elementos.

O solo foi retirado cuidadosamente das colunas e disposto placa de petri para que fosse determinada a altura da coluna de solo ao longo do seu diâmetro com o auxílio de um paquímetro. Em seguida, a massa de solo de cada coluna foi desagregada, seca à temperatura ambiente, pesada, homogeneizada e quarteada para posterior determinação das características químicas e da concentração dos elementos.

\subsection{Determinação das propriedades físicas, químicas e mineralógicas}

As propriedades físicas, químicas e mineralógicas do solo e da cinza de carvão foram determinadas para ajudar na compreensão da retenção ou mobilidade dos elementos tóxicos no solo.

\subsubsection{Cinza de carvão}

A cinza de carvão não foi lixiviada foi caracterizada quanto ao $\mathrm{pH}$, tamanho da partícula, mineralogia e composição elementar. 
$\mathrm{O}$ pH da cinza de carvão foi determinado em solução de $\mathrm{KCl} 1 \mathrm{~mol} \mathrm{~L}^{-1} \mathrm{e}$ em $\mathrm{H}_{2} \mathrm{O}$ na proporção cinza:solução 1:2,5 após agitação por 10 minutos de acordo com a metodologia adotada para determinação de $\mathrm{pH}$ em solos (EMBRAPA, 1997).

$\mathrm{O} \mathrm{pH}$ da cinza também foi determinado em $\mathrm{H}_{2} \mathrm{O}$ na proporção $0,800 \mathrm{~g}$ de cinza e $40 \mathrm{~mL}$ de $\mathrm{H}_{2} \mathrm{O}$ após agitação por 24 horas, segundo metodologia descrita por PIRES e QUEROL (2004) e em $\mathrm{H}_{2} \mathrm{O}$ na proporção cinza:solução 1:2,5 após agitação por 24 horas.

A mineralogia da cinza de carvão foi determinada por difração de raios-X, por meio do método do pó, mediante o emprego do difratômetro de raios$X$, marca PANalytical modelo X'Pert PRO com detector X'Celerator do Laboratório de Caracterização Tecnológica da Escola Politécnica da Universidade de São Paulo (LCT-POLI-USP). A identificação das fases cristalinas foi obtida por comparação do difratograma da amostra com o banco de dados PDF2 do International Center for Diffraction Data (2003) e PANalytical Inorganic Crystal Structure Database (2007).

O tamanho da partícula da cinza de carvão foi determinado pela distribuição das partículas obtida pelo método de dispersão em álcool isopropílico, no LCT-POLI-USP.

A composição elementar da cinza de carvão foi obtida por análise semiquantitativa sem padrões no LCT-POLI-USP com análise química de elementos de flúor a urânio em espectrômetro por fluorescência de raios- $X$, modelo Axios Advanced, marca PANalytical com perda de fogo (PF) efetuada a $1050^{\circ} \mathrm{C}$.

\subsubsection{Solo}

As propriedades físicas, químicas e mineralógicas foram determinadas nas amostras de solo não lixiviado por três laboratórios diferentes: o laboratório onde foi desenvolvido o presente estudo, localizado no Centro de Química e Meio Ambiente do Instituto de Pesquisas Energéticas e Nucleares (CQMA-IPEN); 
laboratório de análises químicas e físicas do solo no Departamento de Ciência do Solo da Escola Superior de Agricultura "Luiz de Queiroz" da Universidade de São Paulo (ESALQ-USP); e laboratório de caracterização tecnológica (LCT) da Escola Politécnica da Universidade de São Paulo (POLI-USP). A metodologia utilizada em cada ensaio e o respectivo laboratório de execução foram nas TAB.15 e TAB.16.

TABELA 15 - Propriedades físicas determinadas no solo não lixiviado

\begin{tabular}{|c|c|c|c|}
\hline Propriedade (método) & Símbolo & Referência & Laboratório \\
\hline Granulometria (densímetro de Bouyoucos) & - & EMBRAPA (1997) & IPEN \\
\hline Granulometria (classe de diâmetro) & - & - & ESALQ-USP \\
\hline $\begin{array}{l}\text { Massa específica dos sólidos ou densidade das partículas (balão } \\
\text { volumétrico com álcool etílico) }\end{array}$ & $\rho_{s}$ & EMBRAPA (1997) & IPEN \\
\hline $\begin{array}{l}\text { Massa específica dos sólidos ou densidade das partículas } \\
\text { (picnômetro com água) }\end{array}$ & $\rho_{s}$ & - & ESALQ-USP \\
\hline Porosidade & $n$ & EMBRAPA (1997) & IPEN \\
\hline Umidade atual ou umidade de campo (gravimétrico) & $w$ & EMBRAPA (1997) & IPEN \\
\hline Umidade residual (gravimétrico) & $W_{r}$ & EMBRAPA (1997) & IPEN \\
\hline Massa específica seca ou densidade do solo (anel volumétrico) & $\rho_{d}$ & EMBRAPA (1997) & IPEN \\
\hline Condutividade elétrica (proporção solo:solução 1:2,5) & CE & - & ESALQ-USP \\
\hline Cor & - & Carta de Munsell & IPEN \\
\hline
\end{tabular}

Algumas propriedades físicas listadas na TAB.15 foram determinadas visando a montagem das colunas de solo e a classificação do solo quanto à granulometria para classificação da textura do solo. 
TABELA 16 - Propriedades químicas determinadas no solo não lixiviado

\begin{tabular}{|c|c|c|c|}
\hline Propriedade (método) & Símbolo & Referência & Laboratório \\
\hline pH (proporção solo:solução 1:2,5 em $\mathrm{H}_{2} \mathrm{O}$ e em KCl $1 \mathrm{~mol} \mathrm{~L}^{-1}$ ) & $\mathrm{pH}_{\mathrm{KCl}} \mathrm{e}$ & EMBRAPA (1997) & $\begin{array}{l}\text { IPEN e ESALQ- } \\
\text { USP }\end{array}$ \\
\hline $\mathrm{pH}$ (proporção solo:solução $1: 2,5 \mathrm{em} \mathrm{CaCl}_{2} 0,01 \mathrm{~mol} \mathrm{~L}^{-1}$ ) & $\mathrm{pH}_{\mathrm{CaCl} 2}$ & - & ESALQ-USP \\
\hline Matéria Orgânica (mufla a $375^{\circ} \mathrm{C}$ ) & $\mathrm{MO}$ & $\begin{array}{l}\text { ABNT-NBR } 13360 \\
\text { (adaptado) }\end{array}$ & IPEN \\
\hline Matéria Orgânica (dicromato/titulométrico) & MO & - & ESALQ-USP \\
\hline $\begin{array}{l}\text { Capacidade de Troca Catiônica (saturação com } \mathrm{BaCl}_{2} \text {, troca com } \\
\mathrm{MgSO}_{4} \text { e titulação com EDTA) }\end{array}$ & CTC & EMBRAPA (1997) & IPEN \\
\hline $\mathrm{P}, \mathrm{K}, \mathrm{Na}, \mathrm{Ca}$ e $\mathrm{Mg}$ (extração pela resina trocadora de íons) & - & - & ESALQ-USP \\
\hline Al (extração por $\mathrm{KCl} 1 \mathrm{~mol} \mathrm{~L}^{-1}$ ) & - & - & ESALQ-USP \\
\hline $\mathrm{H}+\mathrm{Al}\left(\right.$ extração em $\left.\mathrm{Ca}\left(\mathrm{CH}_{3} \mathrm{OO}\right)_{2} \cdot \mathrm{H}_{2} \mathrm{O}\right)$ & - & - & ESALQ-USP \\
\hline $\mathrm{Si}$ (extração por $\mathrm{CaCl}_{2} 0,01 \mathrm{~mol} \mathrm{~L}^{-1}$ ) & - & - & ESALQ-USP \\
\hline Soma das Bases $\left(\mathrm{SB}=\mathrm{Na}^{+}, \mathrm{K}^{+}, \mathrm{Ca}^{2+}, \mathrm{Mg}^{2+}\right)$ & SB & - & ESALQ-USP \\
\hline Capacidade de Troca Catiônica Efetiva $\left(\mathrm{CTC}_{\mathrm{E}}=\mathrm{SB}+\mathrm{Al}\right)$ & $\mathrm{CTC}_{\mathrm{E}}$ & - & ESALQ-USP \\
\hline Capacidade de Troca Catiônica Total $\left(\mathrm{CTC}_{\mathrm{t}}=\mathrm{SB}+(\mathrm{H}+\mathrm{Al})\right)$ & CTC $_{t}$ & - & ESALQ-USP \\
\hline Saturação por Bases $\left(\mathrm{V} \%=\mathrm{SB} \times 100 / \mathrm{CTC}_{\mathrm{t}}\right)$ & V\% & - & ESALQ-USP \\
\hline Saturação por Alumínio $\left(\mathrm{m} \%=\mathrm{Al} \times 100 / \mathrm{CTC}_{\mathrm{E}}\right)$ & $\mathrm{m} \%$ & - & ESALQ-USP \\
\hline Óxidos (ataque sulfúrico) & - & EMBRAPA (1997) & $\begin{array}{l}\text { IPEN e ESALQ- } \\
\text { USP }\end{array}$ \\
\hline $\mathrm{SiO}_{2}$ (extração em $\mathrm{NaOH}_{2} \mathrm{O}$ ) & - & & ESALQ-USP \\
\hline Nitrogênio Total, $\mathrm{N}-\mathrm{NO}_{3}$ e N-NH${ }_{4}$ (digestão sulfúrica/kjeldahl) & - & - & ESALQ-USP \\
\hline
\end{tabular}

As propriedades físicas e químicas foram determinadas em duplicatas ou mais réplicas e todos os reagentes utilizados foram de grau para análise.

A mineralogia do solo foi determinada por difração de raios-X (DRX) no laboratório LCT-POLI-USP, na amostra de solo peneirado a 0,075 $\mathrm{mm}$, pelo uso do jogo de peneiras de 50,38, 25, 19, 9,5, 4,8, 2,0, 1,2, 0,6, 0,42, 0,25, 0,15 e $0,075 \mathrm{~mm}$. O equipamento para a DRX utilizado foi o mesmo da cinza de carvão, descrito no item 4.7.1.

A composição elementar do solo não lixiviado foi obtida por análise semiquantitativa em espectrômetro por fluorescência de raios-X (FRX) no laboratório da LCT-POLI-USP, utilizando-se a mesma metodologia e equipamento descritos para a FRX da cinza de carvão, descrito no item 4.7.1. 
Após o período de lixiviação o $\mathrm{pH}$ em $\mathrm{H}_{2} \mathrm{O}$ e $\mathrm{KCl} 1$ mol L ${ }^{-1}$ e os óxidos de $\mathrm{Al}, \mathrm{Mn}$ e Fe foram determinados novamente.

\subsubsection{Percolado das colunas}

O percolado das colunas foi caracterizado quanto ao $\mathrm{pH}$, condutividade elétrica, carbono dissolvido e concentração dos ânions a cada 28 dias.

$\mathrm{O} \mathrm{pH}$ foi determinado com o uso do pHmetro digital modelo MPA-210P e a condutividade elétrica com o uso do condutivímetro modelo W12D ambos da BEL Engineering.

A concentração de carbono total dissolvido (CTD), carbono inorgânico dissolvido (CID) e carbono orgânico dissolvido (COD) foi determinada numa alíquota de $50 \mathrm{~mL}$ do percolado das colunas a cada 28 dias. Esta alíquota foi filtrada a vácuo em membrana de acetato de 0,45 $\mu \mathrm{m}$ de porosidade e a medida de carbono dissolvido foi determinada usando o aparelho TOC- $\mathrm{V}_{\mathrm{CPH}}$ da Shimadzu.

As alíquotas de $50 \mathrm{~mL}$ dos percolados das colunas foram mantidas congeladas para posterior medida da concentração dos ânions $\left(\mathrm{SO}_{4}{ }^{2-}, \mathrm{NO}_{3}{ }^{-}, \mathrm{F}^{-}\right.$, $\mathrm{Cl}^{-}, \mathrm{NO}_{2}^{-}$e $\left.\mathrm{PO}_{4}{ }^{3-}\right)$ num cromatógrafo de íons, cujas especificações de modelo e uso foram na TAB.17.

TABELA 17 - Especificações e condições adotadas no cromatógrafo de íons

\begin{tabular}{ll}
\hline Característica & Especificação \\
\hline Modelo do cromatógrafo: & DX120 \\
Marca: & DIONEX \\
Coluna analítica: & IonPac AS14 $(4 \times 250 \mathrm{~mm})$ \\
Coluna de guarda: & IonPac AS14 $(4 \times 50 \mathrm{~mm})$ \\
Eluente: & $2,7 \mathrm{mM} \mathrm{L}^{-1}$ de $\mathrm{NaCO}_{3}$ e $1,0 \mathrm{mM} \mathrm{L}^{-1}$ de $\mathrm{NaHCO}_{3}$ \\
\hline
\end{tabular}

\subsection{Determinação da concentração dos elementos}

A concentração dos elementos majoritários $\mathrm{Al}, \mathrm{Mn}, \mathrm{Fe}, \mathrm{Na}, \mathrm{Mg}, \mathrm{Si}, \mathrm{K}$ e $\mathrm{Ca}$ e os elementos traço e tóxicos $\mathrm{As}, \mathrm{Cd}, \mathrm{Mo}, \mathrm{Pb}$ e $\mathrm{Zn}$ foi determinada nas amostras de percolado, extratos de solo e extratos de cinza de carvão. Para a determinação das medidas de concentração dos elementos nas amostras foi 
utilizado o espectrômetro de emissão atômica com fonte de plasma acoplada indutivamente (ICP-OES), modelo M120E da Spectroflame, exceto para os elementos $\mathrm{As}$ e $\mathrm{Pb}$ determinados no percolado das colunas. Para a determinação das medidas de concentração desses elementos no percolado das colunas foi utilizado o espectrômetro de absorção atômica com forno de grafite (AAS-GF), modelo AAS-GF $800 \mathrm{com}$ forno de grafite modelo HGA 400 da Perkin Elmer. Essas medidas de concentração foram determinadas no Laboratório de Análises Químicas e Ambientais do CQMA-IPEN.

O espectrômetro do tipo ICP-OES consiste numa fonte de plasma que é gerada por uma corrente elétrica contínua de gás argônio ionizado. A amostra líquida aplicada no ICP-OES é transformada em aerossol por um nebulizador dentro de uma câmara, e este aerossol é conduzido ao plasma. As moléculas da amostra (no estado gasoso) são dissociadas e em seguida os átomos são ionizados. Desta maneira, grande parte desses átomos é excitado e produz o espectro de emissão atômica. A radiação emitida é refletida por espelhos para fotomultiplicadoras que alimentam sistemas eletrônicos de medida que traduzem o sinal na forma de resultado.

A técnica tem como vantagem a determinação multielementar em uma única amostra simultaneamente (SKOOG et al., 2002).

O princípio da técnica de análise no espectrômetro do tipo AAS-GF consiste na aspiração de uma amostra líquida até um forno de grafite, no qual esta amostra é atomizada. Uma lâmpada de cátodo oco emite um feixe de luz na amostra atomizada com o mesmo comprimento de onda do elemento a ser analisado. Assim, é possível analisar apenas um elemento por vez. A luz que atravessa a amostra atomizada passa posteriormente por um monocromador $\mathrm{e}$ um detector, no qual é medida a quantidade de luz absorvida pelo elemento na chama (SKOOG et al., 2002). Escolhe-se do método analítico depende de diversos fatores tais como exatidão e precisão necessárias, quantidade de amostra disponível e faixa de concentração do analito. O AAS-GF foi selecionado para análise de $\mathrm{Pb}$ e As no percolado das colunas, pois essa técnica comparada ao ICP-OES permite determinações diretamente sobre amostras em faixas de 
concentração em $\mu \mathrm{g} / \mathrm{L}$, apresenta limites de detecção muito baixos e minimiza os efeitos de interferência espectral.

\subsubsection{Determinação da concentração dos elementos majoritários}

Alíquotas de $50 \mathrm{~mL}$ dos percolados das colunas coletados a cada 28 dias foram acidificadas, filtradas a vácuo em membrana de acetato de 0,45 $\mu \mathrm{m}$ e mantidas resfriadas a $5^{\circ} \mathrm{C}$ para posterior medida das concentrações de $\mathrm{Na}, \mathrm{Mg}$, $\mathrm{Si}, \mathrm{K}, \mathrm{Ca}, \mathrm{Al}, \mathrm{Mn}$ e Fe no ICP-OES. A concentração desses elementos também foi determinada nos extratos ácidos de solo e cinza.

\subsubsection{Determinação da concentração dos elementos tóxicos}

A concentração dos elementos tóxicos $\mathrm{As}, \mathrm{Cd}, \mathrm{Zn}, \mathrm{Pb}$ e Mo foi determinada nas amostras de cinza de carvão, solo e percolado das colunas.

\subsubsection{Determinação da concentração dos elementos tóxicos no percolado}

Alíquotas de $50 \mathrm{~mL}$ dos percolados das colunas coletados a cada 28 dias foram filtradas à vácuo em membrana de acetato de 0,45 $\mu \mathrm{m}$, acidificadas e resfriadas a $5 \stackrel{\circ}{\circ}$ para posterior medida das concentrações de $\mathrm{Cd}, \mathrm{Zn}$ e Mo no ICP-OES e As e Pb no AAS-GF. 


\subsubsection{Determinação da concentração dos elementos tóxicos nos extratos de solo e cinza de carvão}

A concentração dos elementos tóxicos foi determinada nos extratos de solo e cinza de carvão. A concentração dos elementos nos extratos obtidos por digestão ácida, extração com EDTA-NH$H_{4}$ e extração com $\mathrm{Ca}\left(\mathrm{CO}_{3}\right)_{2}$ foi denominada de concentração parcial, concentração biodisponível e concentração trocável, respectivamente.

\subsection{Extratos de solo e cinza de carvão obtidos por digestão ácida em forno de micro-ondas}

Os métodos de digestão ácida para análises de elementos em matrizes sólidas como solos são amplamente adotados por organizações ambientais regulamentadoras nacionais e internacionais. Esses métodos consistem na dissolução dos elementos presentes na matriz sólida, que uma vez dissolvidos, são quantificados por procedimentos analíticos. A dissolução dos elementos ocorre por dois mecanismos principais: 1) pela oxidação da matéria orgânica; 2) pelo grau de dissolução da fase mineral. O grau de dissolução da fase mineral depende tanto da força do ácido quanto da composição da fase mineral. Os processos de digestão que extraem os elementos ligados em todas as frações do solo, ou seja, até na fração silicato, são denominados processos de digestão total e os processos que extraem os elementos até a fração óxido são denominados como processos de digestão parcial (RAIJ et al., 2001). A digestão total é obtida pelo uso de ácidos mais fortes, ou mistura de ácidos. Geralmente, o ácido fluorídrico é utilizado nesse tipo de digestão. Na digestão parcial são utilizados ácidos, que mesmo concentrados, não solubilizam os elementos ligados à fração silicato.

A digestão parcial representa uma disponibilidade potencial dos elementos tóxicos, uma vez que, num ambiente natural dificilmente o solo será submetido a uma condição tão drástica de dissolução da fase sólida, como ocorre na digestão total. 
O uso do forno micro ondas na digestão das amostras reduz o tempo de digestão em relação aos métodos que utilizam chapas elétricas. Além disso, a digestão no forno micro ondas reduz o risco de contaminação da amostra e a perda de espécies voláteis, possibilita a redução do uso da quantidade de amostra e reagente e proporciona maior segurança para o operador (SANDRONI e SMITH, 2002).

Os elementos foram extraídos em $500 \mathrm{mg}$ das amostras de solo e cinza de carvão por digestão ácida parcial com $\mathrm{HNO}_{3}(9 \mathrm{~mL})$ e $\mathrm{HCl}(3 \mathrm{~mL})$ concentrados em forno de micro ondas e em seguida diluídos para $50 \mathrm{~mL}$ segundo a metodologia da USEPA 3051-A (1998). O forno micro ondas utilizado foi da marca Provecto Analítica modelo DGT 100 Plus e as condições de tempo e potência foram:

- passo 1: dois minutos e potência de 250W;

- passo 2: vinte minutos e potência de $600 \mathrm{~W}$;

- passo 3: doze minutos e potência zero.

O mesmo procedimento foi repetido para as amostras de solo lixiviado e cinza lixiviada.

As amostras de cinza e solo foram preparadas em duplicata. Para controle de qualidade das amostras de solo, a cada digestão realizada no forno micro-ondas foram inseridos seis frascos digestores distribuídos da seguinte maneira: quatro frascos de amostras de solo, um frasco de uma amostra branco (composta apenas por $9 \mathrm{~mL}$ de $\mathrm{HNO}_{3}$ e $3 \mathrm{~mL}$ de $\mathrm{HCl}$ ) e um frasco com um material de referência de solo do NIST (National Institute for Standard and Technology), sendo que, foi utilizado o NIST 2109 (San Joaquin Soil) para os solos não lixiviado e lixiviado das colunas de solo sem cinza e o NIST 2711 (Montana Soil) para as amostras de solo das colunas de solo+cinza. Para evitar contaminação das amostras no frasco de digestão, após cada digestão, os frascos foram submetidos a uma limpeza com $10 \mathrm{~mL}$ de $\mathrm{HNO}_{3}$ concentrado no 
forno de micro-ondas sob as mesmas condições de tempo e potência descritas anteriormente.

Os extratos ácidos de $50 \mathrm{~mL}$ de solo e cinza foram filtrados com papel de filtro faixa branca de porosidade $6 \mu \mathrm{m}$ e resfriados em refrigerador a $5 \stackrel{\circ}{\circ} \mathrm{C}$ para posterior determinação da concentração dos elementos para por ICP-OES. Nesses mesmos extratos foram determinadas também a concentração dos elementos majoritários $\mathrm{Na}, \mathrm{Mg}, \mathrm{Si}, \mathrm{K}, \mathrm{Ca}, \mathrm{Al}, \mathrm{Mn}$ e $\mathrm{Fe}$. A concentração dos elementos foi denominada como concentração parcial.

\subsection{Extratos de solo obtidos por extração biodisponível com EDTA- $\mathrm{NH}_{4} 0,05 \mathrm{~mol} \mathrm{~L}^{-1}$}

O solo lixiviado foi submetido à extração dos elementos por um agente quelante. A metodologia adotada foi com base no método proposto por URE (1996). A extração dos elementos do solo como agente quelante EDTA-NH $\mathrm{N}_{4}$ 0,05 mol $\mathrm{L}^{-1}$ foi selecionada. Essa metodologia foi selecionada porque esse autor encontrou uma boa exatidão e reprodutibilidade para este método e pela disponibilidade de um material de referência. Além disso, a fração dos elementos tóxicos em solos extraídos por EDTA está relacionada com a absorção desses elementos por plantas, por isso é considerada como fração biodisponível (LAMBRECHTS et al., 2011).

GARRABRANTS e KOSSON (2000) e VOGLAR e LESTAN (2012) que avaliaram a extração de alguns elementos tais como $\mathrm{Cd}, \mathrm{Pb}, \mathrm{Zn}$ e As no solo, também relatouram a boa eficiência do extrator EDTA.

O agente quelante reage com os íons livres dos elementos em solução, formando complexos solúveis, o que resulta em redução da atividade dos elementos livres em solução, amostras de $2 \mathrm{~g}$ de solo lixiviado foram misturada a $40 \mathrm{~mL}$ de EDTA-NH $\mathrm{NH}_{4} 0,05 \mathrm{~mol} \mathrm{~L}^{-1}(\mathrm{pH}=7,0)$ por agitação num misturador horizontal por 1 hora. Os extratos de $40 \mathrm{~mL}$ foram obtidos por centrifugação de 15 minutos. Os extratos de solo foram filtrados a vácuo em membrana de acetato de $0,45 \mu \mathrm{m}$, acidificados e resfriados em refrigerador a $5 \stackrel{\circ}{\mathrm{C}}$ para posterior determinação da concentração dos elementos As, Cd, Mo, $\mathrm{Pb}$ e Zn no ICP-OES. 
A concentração dos elementos foi denominada como concentração biodisponível. Então, os íons desses elementos dessorvem da superfície do solo ou dissolvem da fase sólida para reabastecer a solução do solo (RAIJ et al., 2001).

As amostras de solo foram preparadas em duplicata. Para controle de qualidade das amostras foram inseridas duas amostras branco e duas amostras de um material de referência para solo certificado pelo Community Bureau of Reference (BCR 484).

\subsection{Extratos de solo obtidos por extração da fração trocável com $\mathrm{Ca}\left(\mathrm{NO}_{3}\right)_{2} 0,1 \mathrm{~mol} \mathrm{~L}^{-1}$}

$\mathrm{O} \mathrm{Ca}\left(\mathrm{NO}_{3}\right)_{2}$ foi selecionado como extrator dos elementos tóxicos retidos no solo, porque o cálcio e nitrato são comumente encontrados na solução do solo e o cálcio é bivalente assim como os cátions de interesse no presente estudo. A solução de $\mathrm{Ca}\left(\mathrm{NO}_{3}\right)_{2}$ extrai os elementos tóxicos ligados à fração trocável do solo e na fração solúvel do solo. Esse extrator foi selecionado, pois o $\mathrm{Ca}\left(\mathrm{NO}_{3}\right)_{2}$ não interfere no $\mathrm{pH}$ do meio e o nitrato não forma complexos com os elementos de interesse, esse seria o motivo pelo qual não se optou pelo uso do $\mathrm{CaCl}_{2}$, uma vez que, o $\mathrm{Cl}^{-1}$ pode ocasionar a precipitação do $\mathrm{Pb}$ e formar complexo com Cd e Zn (CAMARGO, 2005).

O cálcio e o nitrato são considerados, respectivamente, como ácido e base de Lewis forte e por isso possuem boa capacidade de deslocar os elementos dos colóides do solo por reações de troca iônica.

Na equação 10 é descrita a reação de troca iônica do cálcio com um metal genérico $\mathrm{M}^{+2}$ ligado a uma partícula trocadora $\mathrm{X}$ :

$\mathrm{M}-\mathrm{X}_{2}+\mathrm{Ca}^{+2} \leftrightarrow \mathrm{Ca}-\mathrm{X}_{2}+\mathrm{M}^{+2}$

O procedimento adotado com base no método proposto por CONDER et al. (2001) foi o seguinte: amostras de $2 \mathrm{~g}$ de solo lixiviado foram misturadas a $40 \mathrm{~mL}$ de $\mathrm{Ca}\left(\mathrm{NO}_{3}\right)_{2} \quad 0,1 \mathrm{~mol} \mathrm{~L}^{-1}$ por agitação num misturador horizontal por 16 horas. Os extratos de $40 \mathrm{~mL}$ foram obtidos por centrifugação de 15 minutos. Os extratos do solo foram filtrados a vácuo em membrana de acetato de 0,45 $\mu \mathrm{m}$, 
acidificados e resfriados a $5 \stackrel{\circ}{\circ}$ em refrigerador para posterior determinação da concentração dos elementos $\mathrm{As}, \mathrm{Cd}$, Mo, $\mathrm{Pb}$ e $\mathrm{Zn}$ no ICP-OES. A concentração dos elementos foi denominada como concentração trocável.

As amostras de solo foram preparadas em duplicata. Para controle de qualidade das amostras foram inseridas duas amostras branco.

O esquema da determinação dos elementos foi exposto na FIG.16.

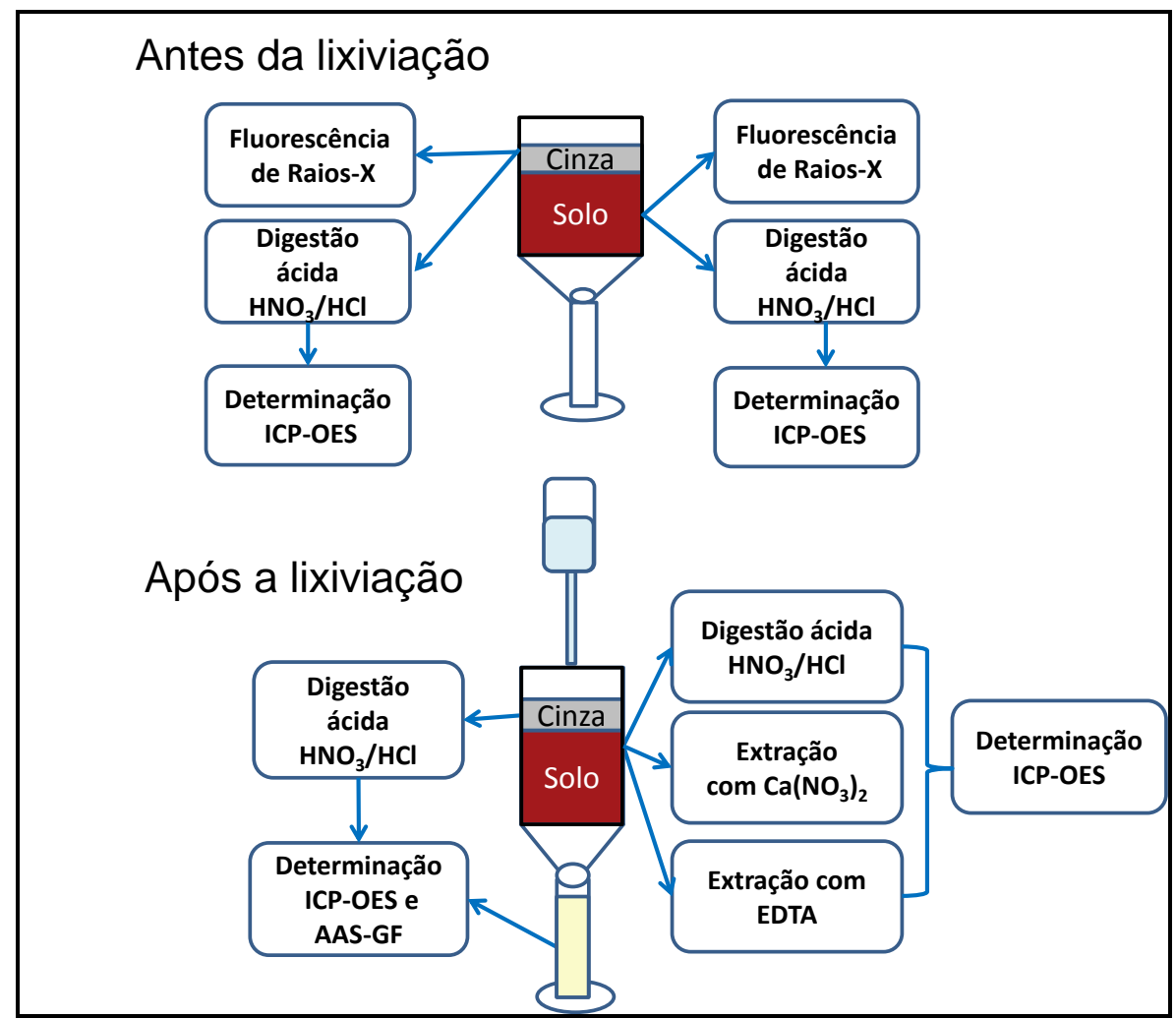

FIGURA 16 - Esquema da determinação da concentração dos elementos nas amostras de cinza de carvão, solo e percolado das colunas

\subsection{Tratamento dos dados}

\subsubsection{Coeficiente de partição}

O coeficiente de partição $(\mathrm{Kp})$ pode ser definido como a razão entre as concentrações do elemento nas fases sólida e líquida do solo. O valor do $\mathrm{Kp}$ indicou a mobilidade relativa entre os elementos no solo. Os elementos que tendem a ficar mais retidos na fase sólida do solo apresentam valores de Kp mais 
elevados do que de outros elementos que tendem a ficar na solução do solo e que, portanto, são elementos mais móveis.

O coeficiente de partição dos elementos tóxicos no solo foi calculado com base na metodologia adotada por CAMARGO (2005). O Kp $\mathrm{EDTA}_{\text {A }}$ foi calculado conforme equação 11 e o $\mathrm{Kp}_{\mathrm{Ca}(\mathrm{NO}) 2}$ conforme equação 12.

$$
\text { Kp EDTA }=\frac{\text { concentração parcial do metal na fase sólida do solo }}{\text { concentração biodisponível do metal na fase líquida do solo }}
$$

$\mathrm{KpCa}_{\mathrm{CN} \mathrm{3}_{2} 2}=\frac{\text { concentração parcial do metal na fase sólida do solo }}{\text { concentração trocável do metal na fase líquida do solo }}$

Em que a concentração parcial do elemento na fase sólida do solo é a concentração no extrato do solo obtido por digestão ácida (item 4.8.2.2.1), a concentração biodisponível do elemento na fase líquida do solo é a concentração no extrato do solo obtido por extração com EDTA-NH $\mathrm{NH}_{4}$ (item 4.8.2.2.2) e concentração trocável na fase líquida do solo é a concentração no extrato obtido por extração com $\mathrm{Ca}\left(\mathrm{NO}_{3}\right)_{2}$ (item 4.8.2.2.3).

\subsubsection{Especiação dos elementos tóxicos}

Os dados da concentração dos ânions, elementos tóxicos, macroelementos, carbono total dissolvido e $\mathrm{pH}$ dos percolados das colunas de cinza, solo e solo+cinza foram aplicados no modelo hidrogeoquímico do programa de computação PHREEQC (PARKHUST, 1995) para estimar a composição química dos elementos tóxicos no percolado das colunas. Esse modelo de especiação baseia-se no cálculo da distribuição das espécies químicas aquosas e dos índices de saturação dos minerais, por meio de consulta a um banco de dados de termodinâmica de reações (BERTOLO, 2001).

A avaliação da composição das espécies químicas aquosas formadas pelos elementos tóxicos nos percolados das colunas pode indicar as possíveis reações químicas ocorridas entre o solo e os elementos tóxicos. 


\subsubsection{Balanço de massas}

O balanço de massa dos elementos tóxicos no sistema cinza/solo/percolado foi expresso por:

$m_{c}=m_{s}+m_{p}$

Em que mc é a massa do elemento lixiviado da cinza, ms é a massa do elemento na coluna de solo e mp é a massa do elemento no percolado.

A massa mc foi calculada por dois métodos: pela diferença entre as massas do elemento na cinza não lixiviada e na cinza lixiviada (equação 14) e pela somatória das massas do elemento no percolado das colunas ao longo de 336 dias de lixiviação (equação 15):

$$
m_{c}=C_{c} \cdot M_{C}-C_{c l} \cdot M_{c}
$$

Em que Cc é a concentração do elemento tóxico ( $\left.\mathrm{mg} \mathrm{kg}^{-1}\right)$ na cinza não lixiviada, Mc é a massa de cinza $(\mathrm{kg})$ adicionada na coluna de solo, Ccl é a concentração do elemento $\left(\mathrm{mg} \mathrm{kg}^{-1}\right)$ na cinza lixiviada sobre a coluna de solo.

$$
\mathrm{mc}=\sum_{\mathrm{t}=28}^{336}\left(\mathrm{C}_{\mathrm{p}} \cdot \mathrm{V}_{\mathrm{p}}\right) \mathrm{t}
$$

Em que $\mathrm{Cp}$ é a concentração do elemento tóxico no percolado das colunas de cinza ( $\mathrm{mg} \mathrm{L}^{-1}$ ) e $\mathrm{Vp}$ é o volume do percolado das colunas de cinza (L) no tempo t variando de 28 a 336 dias de lixiviação.

As massas $\mathrm{ms}$ e $\mathrm{mp}$ foram calculadas pelas equações 16 e 17, respectivamente.

$$
\mathrm{ms}=\mathrm{C}_{\mathrm{s}} \cdot \mathrm{Ms}
$$

em que Cs é a concentração do elemento $\left(\mathrm{mg} \mathrm{kg}^{-1}\right)$ no solo e Ms é a massa do solo $\left(\mathrm{kg}^{-1}\right)$.

$$
\mathrm{mp}=\sum_{\mathrm{t}=28}^{336}\left(\mathrm{C}_{\mathrm{p}} \cdot \mathrm{V}_{\mathrm{p}}\right)_{\mathrm{t}}
$$


Em que $\mathrm{Cp}$ é a concentração do elemento tóxico no percolado das colunas de solo+cinza $\left(\mathrm{mg} \mathrm{L}^{-1}\right)$ e $\mathrm{Vp}$ é o volume do percolado das colunas de solo+cinza (L) no tempo t variando de 28 a 336 dias de lixiviação.

\subsubsection{Matriz de correlação}

Os dados de concentração dos elementos obtidos no percolado das colunas pela lixiviação foram relacionados com os dados de caracterização do percolado das colunas por meio de uma matriz de correlação, com o objetivo de investigar quais foram as principais propriedades que influenciaram na mobilidade dos elementos tóxicos.

\subsection{Fluxograma da metodologia do estudo}

Na FIG.17 foi exposto o fluxograma da metodologia do estudo com o intuito de se resumir as etapas realizadas neste trabalho. 


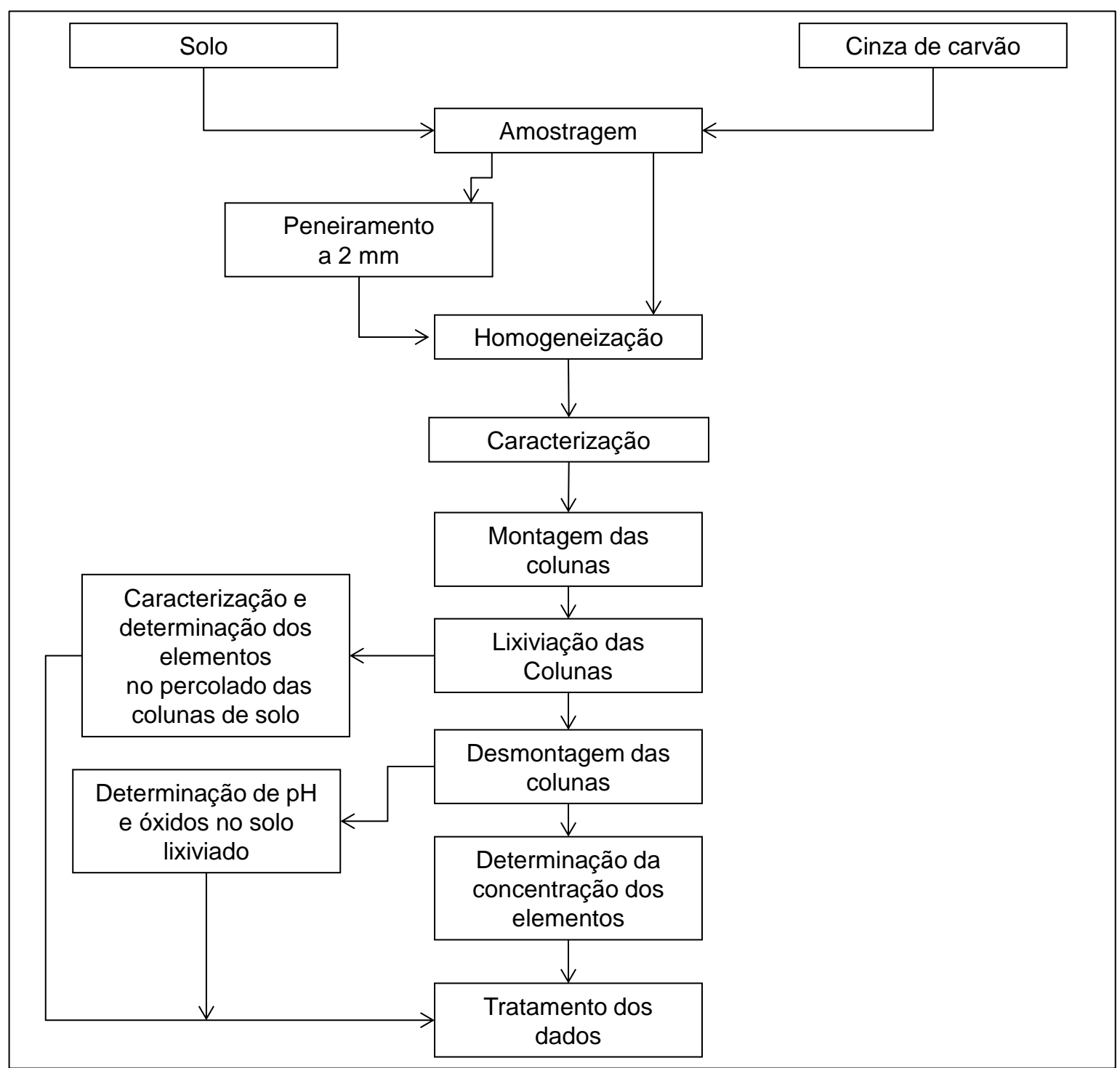

FIGURA 17 - Fluxograma da metodologia de estudo 


\section{RESULTADOS E DISCUSSÕES}

\subsection{Cinza de carvão}

As características físicas, químicas e mineralógicas da cinza de carvão variam de acordo com as características do mineral natural que as gerou, com o tipo de queima do carvão, projeto e operação da caldeira, grau de beneficiamento e moagem do carvão, sistema de extração e manuseio (IZIDORO, 2008).

\subsubsection{Caracterização física e química da cinza de carvão}

Na TAB.18 foi mostrada a composição química da cinza de carvão obtida por fluorescência de raios-X.

TABELA 18 - Composição química da cinza de carvão obtida por fluorescência de raios- $X$

\begin{tabular}{ccccccccccccccc}
\hline $\begin{array}{c}\mathrm{Na}_{2} \mathrm{O} \\
(\%)\end{array}$ & $\begin{array}{c}\mathrm{MgO} \\
(\%)\end{array}$ & $\begin{array}{c}\mathrm{Al}_{2} \mathrm{O}_{3} \\
(\%)\end{array}$ & $\begin{array}{c}\mathrm{SiO}_{2} \\
(\%)\end{array}$ & $\begin{array}{c}\mathrm{P}_{2} \mathrm{O}_{5} \\
(\%)\end{array}$ & $\begin{array}{c}\mathrm{SO}_{3} \\
(\%)\end{array}$ & $\begin{array}{c}\mathrm{Cl} \\
(\%)\end{array}$ & $\begin{array}{c}\mathrm{K}_{2} \mathrm{O} \\
(\%)\end{array}$ & $\begin{array}{c}\mathrm{CaO} \\
(\%)\end{array}$ & $\begin{array}{c}\mathrm{TiO}_{2} \\
(\%)\end{array}$ & $\begin{array}{c}\mathrm{V}_{2} \mathrm{O}_{5} \\
(\%)\end{array}$ & $\begin{array}{c}\mathrm{Cr}_{2} \mathrm{O}_{3} \\
(\%)\end{array}$ & $\begin{array}{c}\mathrm{MnO}^{2} \\
(\%)\end{array}$ & $\begin{array}{c}\mathrm{Fe}_{2} \mathrm{O}_{3} \\
(\%)\end{array}$ & $\begin{array}{c}\mathrm{Co}_{3} \mathrm{O}_{4} \\
(\%)\end{array}$ \\
\hline 1,07 & 0,87 & 18,0 & 54,4 & 0,23 & 2,39 & 0,02 & 2,63 & 1,07 & 1,09 & 0,06 & 0,03 & 0,05 & 8,08 & $\mathrm{nd}$ \\
\hline $\mathrm{NiO}$ & $\mathrm{CuO}$ & $\begin{array}{c}\mathrm{ZnO} \\
(\%)\end{array}$ & $\begin{array}{c}\mathrm{GeO}_{2} \\
(\%)\end{array}$ & $\begin{array}{c}\mathrm{As}_{2} \mathrm{O}_{3} \\
(\%)\end{array}$ & $\begin{array}{c}\mathrm{Rb}_{2} \mathrm{O} \\
(\%)\end{array}$ & $\begin{array}{c}\mathrm{SrO} \\
(\%)\end{array}$ & $\begin{array}{c}\mathrm{Y}_{2} \mathrm{O}_{3} \\
(\%)\end{array}$ & $\begin{array}{c}\mathrm{ZrO}_{2} \\
(\%)\end{array}$ & $\begin{array}{c}\mathrm{Nb}_{2} \mathrm{O}_{5} \\
(\%)\end{array}$ & $\begin{array}{c}\mathrm{MoO}_{3} \\
(\%)\end{array}$ & $\begin{array}{c}\mathrm{BaO} \\
(\%)\end{array}$ & $\begin{array}{c}\mathrm{PbO}^{(\%)} \\
(\%)\end{array}$ & $\begin{array}{c}\mathrm{U}_{3} \mathrm{O}_{8} \\
(\%)\end{array}$ & $\begin{array}{c}\mathrm{PF} \\
(\%)\end{array}$ \\
\hline 0,01 & 0,01 & $\mathbf{0 , 1 6}$ & 0,01 & $\mathbf{0 , 1 9}$ & 0,01 & 0,05 & 0,02 & 0,12 & $\mathrm{nd}$ & $\mathbf{0 , 0 1}$ & 0,07 & $\mathbf{0 , 0 6}$ & 0,03 & 9,3 \\
\hline
\end{tabular}

Esses resultados estão de acordo com os obtidos por DEPOI et al. (2008) e LEVANDOWISKI e KALKREUTH (2009), que também analisaram a cinza leve da usina de Figueira, com pequenas variações referentes aos elementos traço.

Neste trabalho foram considerados como elementos de estudo o As, $\mathrm{Cd}$, Mo, $\mathrm{Pb}$ e $\mathrm{Zn}$ por apresentarem toxicidade maior e concentração na cinza de carvão e no solo analisado ao redor da usina termelétrica de Figueira (FLUES et al., 2008; CAMARGO, 2005). Os resultados da TAB.18 mostram a presença de As, $\mathrm{Pb}, \mathrm{Zn}$ e Mo na cinza de carvão e o Cd não foi analisado por limitações do equipamento. $\mathrm{O}$ arsênio e $\mathrm{O} \mathrm{Zn}$ foram os elementos que apresentaram maior concentração na cinza em relação aos elementos $\mathrm{Mo} \mathrm{e} \mathrm{Pb}$.

Os resultados da TAB.18 indicaram também a presença de $\mathrm{Ni}, \mathrm{Cu}, \mathrm{Cr}$ e Ba que são considerados elementos tóxicos pela CETESB (2005) e por MCBRIDE (1994). CAMARGO (2005) avaliou a contaminação do solo por cinza 
de carvão ao redor da usina termelétrica de Figueira e reportou que $\mathrm{Ni}$, $\mathrm{Cu}$ e $\mathrm{Cr}$ não representaram risco à saúde humana. DEPOI et al. (2008) constatou que o $\mathrm{Ba}$, embora presente em concentração superior à outros elementos na cinza de carvão leve de Figueira é dificilmente lixiviado (0,47\%).

$\mathrm{O} \mathrm{pH}$ das cinzas varia de 4,5 a 12 dependendo das características geoquímicas do carvão precursor (FERRET, 2004). Na TAB.19 foram mostrados os valores de $\mathrm{pH}$ determinados na cinza de carvão por meio de três metodologias diferentes.

TABELA 19 - pH da cinza de carvão

\begin{tabular}{cccc}
\hline $\mathrm{pH}_{\mathrm{KCl}}$ & $\mathbf{p H}_{\mathrm{H} 2 \mathrm{O}}$ & $\mathbf{p H}_{\mathrm{H} 2 \mathrm{O}}$ & $\mathbf{p H}_{\mathrm{H} 20}$ \\
\hline Condição: proporção & Condição 1: proporção & Condição 2: proporção & Condição 3: proporção \\
cinza:solução 1:2,5 e 10 & cinza:solução 1:2,5 e 10 & cinza:solução 1:2,5 e 24 & cinza:solução 1:50 e 24 \\
minutos de agitação & minutos de agitação & horas de agitação & horas de agitação \\
Valor: $6,8 \pm 0,3(\mathrm{n}=5)$ & Valor: 6,4 $\pm 0,1(\mathrm{n}=3)$ & Valor: 6,8 $\pm 0,0(\mathrm{n}=2)$ & Valor: 7,4 $\pm 0,0(\mathrm{n}=2)$ \\
$\mathbf{n}=$ número de amostras & & &
\end{tabular}

Os valores descritos na TAB.19 indicaram que o tempo de agitação, a solução de extração, bem como a proporção cinza:solução são parâmetros que influenciam diretamente na medida do pH da cinza. Isso indicou a necessidade de um método padrão para essa análise.

$\mathrm{O} \mathrm{pH}$ da cinza leve da usina termelétrica de Figueira também foi determinado por DEPOl et al. (2008) seguindo a metodologia de PIRES e QUEROL (2004), O extrato obtido pela mistura entre água e cinza, utilizando-se $0,800 \mathrm{~g}$ de cinza leve em $40 \mathrm{~mL}$ de água (proporção cinza:solução 1:50), por um período de 24 horas de agitação, resultou num $\mathrm{pH}$ de 9,18. A diferença de $\mathrm{pH}$ observada entre este resultado e o obtido no presente trabalho, $\mathrm{pH}$ igual a 7,4 (TAB.19), pode ser atribuída a fatores como períodos distintos de coleta da cinza e diferentes características do carvão percursor.

Na FIG.18 foi mostrada a distribuição do tamanho de partícula na amostra de cinza de carvão, indicando que grãos de tamanho $\leq 20 \mu \mathrm{m}$ correspondem a $70 \%$ dos grãos presentes na cinza de carvão em estudo. 


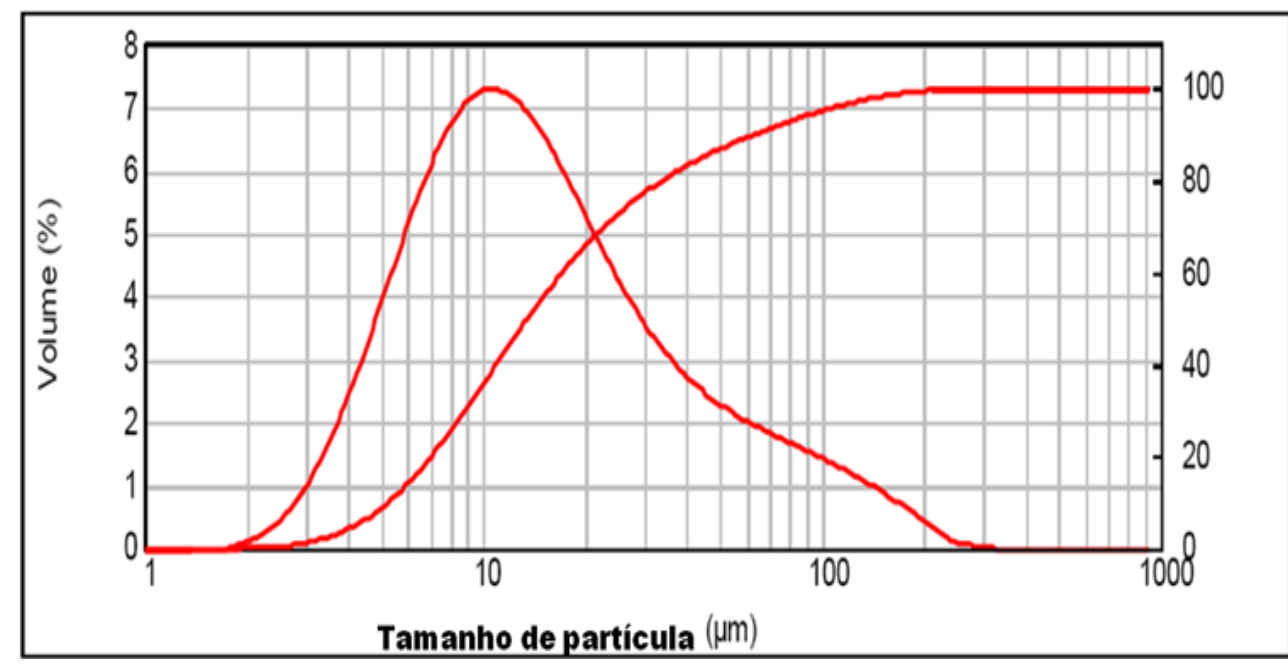

FIGURA 18 - Distribuição do tamanho das partículas da cinza de carvão determinada pelo LCT-POLI-USP

\subsubsection{Caracterização mineralógica da cinza de carvão}

A mineralogia da cinza de carvão foi determinada por difratometria de raios-X e apresentou fases cristalinas de quartzo $\left(\mathrm{SiO}_{2}\right)$, mulita $\left(\mathrm{Al}_{4,59} \mathrm{Si}_{1,41} \mathrm{O}_{9,7}\right)$, hematita $\left(\mathrm{Fe}_{2} \mathrm{O}_{3}\right)$ e magnesioferrita $\left(\mathrm{MgFe}_{2} \mathrm{O}_{3}\right)$, conforme exposto na FIG.19.

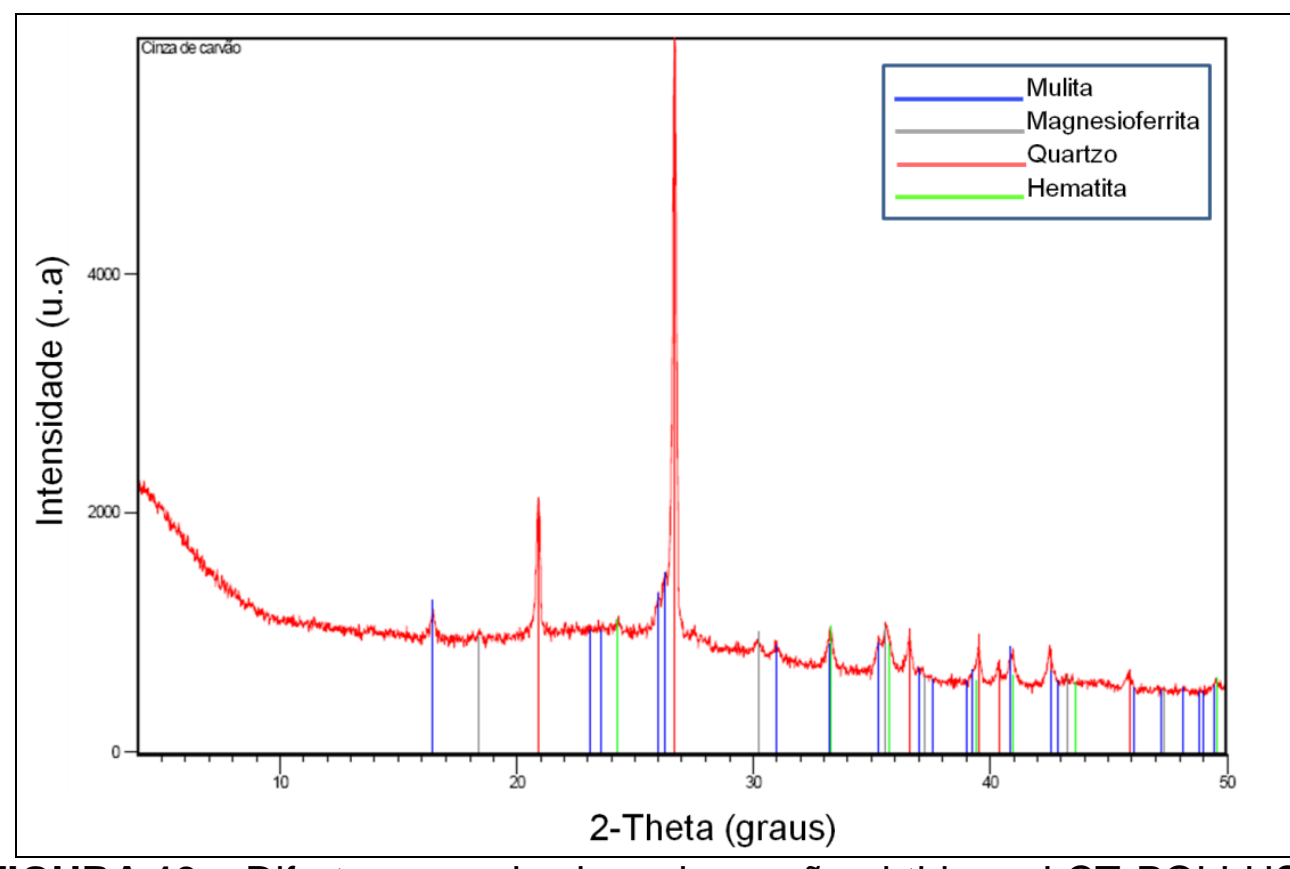

FIGURA 19 - Difratograma da cinza de carvão obtido no LCT-POLI-USP 
Esses resultados estão de acordo com os resultados encontrados por LEVANDOWSKI e KALKREUTH (2009), que também analisaram a mineralogia da cinza leve da usina de Figueira, exceto pela presença de pirita $\left(\mathrm{FeS}_{2}\right)$ e gipsita $\left(\mathrm{CaSO}_{4} \cdot \mathrm{H}_{2} \mathrm{O}\right)$ que também foram descritos pelos autores.

\subsection{Solo}

\subsubsection{Caracterização física e química do solo não lixiviado}

A determinação das propriedades físicas e químicas do solo é importante para avaliar a mobilidade dos elementos neste meio. As propriedades caracterizam o solo e auxiliam na compreensão dos possíveis processos que possam ocorrer no contato com a cinza de carvão.

Na TAB.20 foram apresentadas algumas propriedades físicas do solo em estudo.

TABELA 20 - Propriedades físicas do solo não lixiviado

\begin{tabular}{|c|c|c|c|c|}
\hline \multicolumn{2}{|c|}{ Propriedade } & \multirow[t]{2}{*}{ Unidade } & \multirow{2}{*}{$\frac{\text { Valor }}{180 \pm 0(n=2)}$} & \multirow[t]{2}{*}{ Laboratório } \\
\hline \multirow{12}{*}{ Granulometria } & Argila & & & \\
\hline & Silte & $\mathrm{g} \mathrm{kg}^{-1}$ & $20 \pm 0(n=2)$ & IPEN \\
\hline & Areia & & $800 \pm 0(n=2)$ & \\
\hline & Argila com dispersante & & 201 & \\
\hline & Argila com água & & 75 & \\
\hline & Silte & & 47 & \\
\hline & Areia Total & & 752 & \\
\hline & Areia Muito Grossa & $\mathrm{g} \mathrm{kg}^{-1}$ & 7 & ESALQ-USP \\
\hline & Areia Grossa & & 24 & \\
\hline & Areia Média & & 243 & \\
\hline & Areia Fina & & 416 & \\
\hline & Areia Muito Fina & & 62 & \\
\hline \multirow{2}{*}{\multicolumn{2}{|c|}{$\rho_{s}$ (densidade das partículas) }} & \multirow{2}{*}{$\mathrm{g} \mathrm{cm}^{-3}$} & $2,84 \pm 0,06(n=2)$ & IPEN \\
\hline & & & 2,63 & ESALQ-USP \\
\hline & orosidade) & - & 0,60 & IPEN \\
\hline & nidade atual) & $\%$ & $12,11 \pm 1,79(n=7)$ & IPEN \\
\hline$w_{r}($ & idade residual) & $\%$ & $3,69 \pm 0,84(n=4)$ & IPEN \\
\hline \multirow{2}{*}{\multicolumn{2}{|c|}{$\rho_{d}($ densidade do solo $)$}} & \multirow{2}{*}{$\mathrm{g} \mathrm{cm}^{-3}$} & $1,28 \pm 0,10(n=7)$ & IPEN \\
\hline & & & $1,14 \pm 0,10(n=7)$ & IPEN \\
\hline CE (cC & utividade elétrica) & $\mathrm{dS} \mathrm{m}^{-1}$ & 100,4 & ESALQ-USP \\
\hline
\end{tabular}

$\mathrm{n}=$ número de amostras 
No ensaio de granulometria do solo realizado pelo laboratório do CQMA-IPEN por meio do método do densímetro de Bouyoucos foram obtidos os resultados da granulometria (TAB.20) do solo, com predominância de areia $(80 \%)$, seguido de argila (18\%) e silte (2\%). Esses resultados estão próximos daqueles obtidos pela ESALQ-USP (TAB.20), areia (75\%), argila (20\%) e silte $(5 \%)$.

No presente estudo foi adotado o diagrama de FERET apresentado por RESENDE et al. (2002), o qual é dividido em três frações, areia, argila e silte, para classificar a textura do solo em estudo. Na FIG.20 foi apresentado o diagrama utilizado para tal classificação.

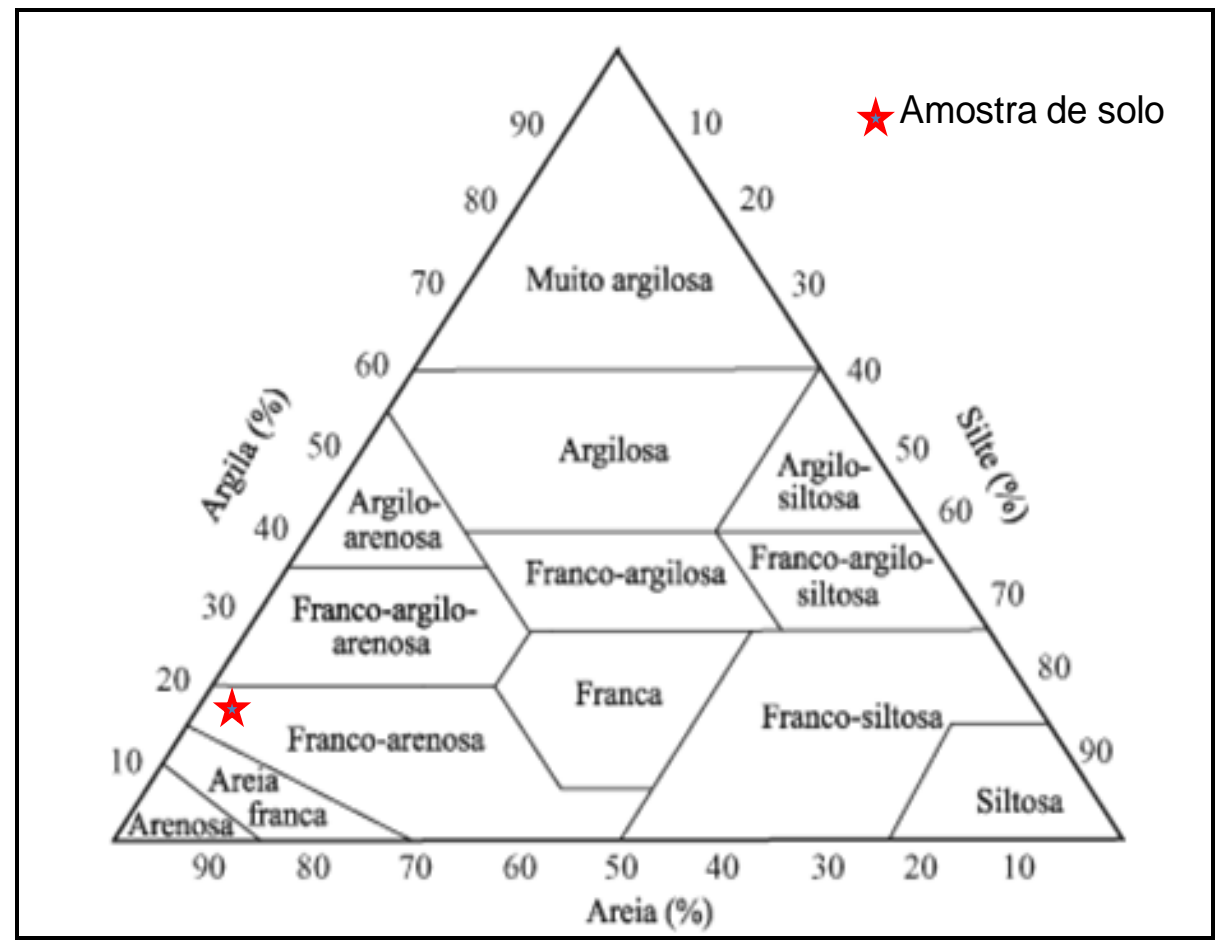

FIGURA 20 - Diagrama de textura adotado pela Sociedade Brasileira de Ciência do Solo (Fonte: RESENDE et al., 2002)

A soma das porcentagens das frações presentes no diagrama de FERET é $100 \%$, e conduzem a um ponto no interior do triângulo. Esse ponto pode estar localizado em uma das áreas, nas quais o triângulo é dividido, e que fornece a classificação da textura do solo (MILLIOLI, 2009). De acordo com esse diagrama, os resultados obtidos no ensaio de distribuição granulométrica 
(TAB.20) indicaram que o solo utilizado pode ser classificado como um solo franco-arenoso, ou seja, um solo com uma mistura de grãos em que a fração areia é predominante.

Segundo o sistema brasileiro de classificação de solos da EMBRAPA (2006), o solo em estudo é considerado um solo de textura média, ou seja, com teores de argila entre 15\% e 34\%, que corresponde numa menor eficiência na retenção dos elementos, quando comparado a solos argilosos. De acordo com MELO e ALLEONI (2009) a textura dos solos é um fator importante no controle da retenção dos elementos tóxicos, pois as partículas mais finas, como as de argila, possuem maior capacidade de retenção desses elementos, devido a maior área superficial específica e quantidade de cargas negativas na superfície.

O ensaio de granulometria do solo também foi realizado no laboratório da ESALQ-USP, por meio do método de classe de diâmetro adotado pela U.S.D.A (United States Department of Agriculture). Os resultados (TAB.20) mostraram que o solo pode ser considerado como um solo de textura médio arenosa, ou seja, com quantidade de argila determinada com dispersante de 150 a $249 \mathrm{~g} \mathrm{~kg}^{-1}$.

Os resultados de densidade de partículas e massa específica seca apresentaram-se coerentes com a classificação textural do solo, pois solos franco-arenosos possuem valores médios de densidade de partículas e massa específica seca em torno de $2,6 \mathrm{~g} \mathrm{~cm}^{-3}$ e $1,2 \mathrm{~g} \mathrm{~cm}^{-3}$, respectivamente (MILLIOLI, 2009).

A cor do solo obtida pelo uso da Carta de Munsel foi 6,25 YR 4/3 e foi relacionada com a mineralogia do solo no item 5.2.2.

Na TAB.21 foi ilustrada a composição química do solo cujos resultados foram obtidos por fluorescência de raios-X. 
Tabela 21 - Composição química do solo obtido por fluorescência de raios-X

\begin{tabular}{|c|c|c|c|c|c|c|c|c|c|c|c|c|c|c|}
\hline $\begin{array}{c}\mathrm{Na}_{2} \mathrm{O} \\
(\%) \\
\end{array}$ & $\begin{array}{c}\mathrm{MgO} \\
(\%)\end{array}$ & $\begin{array}{c}\mathrm{Al}_{2} \mathrm{O}_{3} \\
(\%) \\
\end{array}$ & $\begin{array}{l}\mathrm{SiO}_{2} \\
(\%)\end{array}$ & $\begin{array}{l}\mathrm{P}_{2} \mathrm{O}_{5} \\
(\%) \\
\end{array}$ & $\begin{array}{l}\mathrm{SO}_{3} \\
(\%) \\
\end{array}$ & $\begin{array}{c}\mathrm{Cl} \\
(\%) \\
\end{array}$ & $\begin{array}{l}\mathrm{K}_{2} \mathrm{O} \\
(\%) \\
\end{array}$ & $\begin{array}{c}\mathrm{CaO} \\
(\%)\end{array}$ & $\begin{array}{l}\mathrm{TiO}_{2} \\
(\%) \\
\end{array}$ & $\begin{array}{l}\mathrm{V}_{2} \mathrm{O}_{5} \\
(\%) \\
\end{array}$ & $\begin{array}{c}\mathrm{Cr}_{2} \mathrm{O}_{3} \\
(\%) \\
\end{array}$ & $\begin{array}{c}\mathrm{MnO} \\
(\%) \\
\end{array}$ & $\begin{array}{c}\mathrm{Fe}_{2} \mathrm{O}_{3} \\
(\%) \\
\end{array}$ & $\begin{array}{c}\mathrm{Co}_{3} \mathrm{O}_{4} \\
(\%) \\
\end{array}$ \\
\hline nd & 0,07 & 13,8 & 76,3 & 0,09 & 0,09 & 0,01 & 0,09 & 0,03 & 0,86 & 0,01 & 0,05 & 0,02 & 4,07 & nd \\
\hline $\begin{array}{l}\mathrm{NiO} \\
(\%) \\
\end{array}$ & $\begin{array}{l}\mathrm{CuO} \\
(\%)\end{array}$ & $\begin{array}{l}\mathrm{ZnO} \\
(\%)\end{array}$ & $\begin{array}{c}\mathrm{GeO}_{2} \\
(\%)\end{array}$ & $\begin{array}{c}\mathrm{As}_{2} \mathrm{O}_{3} \\
(\%) \\
\end{array}$ & $\begin{array}{l}\mathrm{Rb}_{2} \mathrm{O} \\
(\%) \\
\end{array}$ & $\begin{array}{l}\mathrm{SrO} \\
(\%) \\
\end{array}$ & $\begin{array}{l}\mathrm{Y}_{2} \mathrm{O}_{3} \\
(\%) \\
\end{array}$ & $\begin{array}{c}\begin{array}{l}\mathrm{ZrO}_{2} \\
(\%)\end{array} \\
\end{array}$ & $\begin{array}{c}\mathrm{Nb}_{2} \mathrm{O}_{5} \\
(\%) \\
\end{array}$ & $\begin{array}{c}\mathrm{MoO}_{3} \\
(\%)\end{array}$ & $\begin{array}{l}\mathrm{BaO} \\
(\%)\end{array}$ & $\begin{array}{l}\mathrm{PbO} \\
(\%)\end{array}$ & $\begin{array}{l}\mathrm{U}_{3} \mathrm{O}_{8} \\
(\%)\end{array}$ & $\begin{array}{l}\mathrm{PF} \\
(\%) \\
\end{array}$ \\
\hline 0,01 & $<<$ & nd & nd & nd & nd & $\ll$ & nd & 0,05 & nd & nd & nd & nd & nd & 4,38 \\
\hline
\end{tabular}

$<<=$ traços (menor que $0,01 \%$ ); nd = elemento não detectado; PF = perda ao fogo.

Observou-se que nenhum dos elementos em estudo ( $\mathrm{As}, \mathrm{Zn}$, Mo e Pb) foi detectado nesse solo e o $\mathrm{Cd}$ não foi analisado por limitações de quantificação do equipamento.

A interação entre os elementos tóxicos em solução e o solo, seja química ou física, depende de uma série de propriedades dos solos. Porém algumas dessas propriedades são tidas como fundamentais nessa interação, tais como: $\mathrm{pH}$, capacidade de troca de cátions (CTC), a fração de argilominerais, os óxidos de Al, Fe e Mn e matéria orgânica (ALLOWAY, 1990). Na TAB.22 foram ilustradas essas e outras propriedades químicas do solo. 
TABELA 22 - Propriedades químicas do solo não lixiviado

\begin{tabular}{|c|c|c|c|c|}
\hline \multirow{2}{*}{\multicolumn{2}{|c|}{ Propriedade }} & \multirow{2}{*}{ Unidade } & \multicolumn{2}{|c|}{ Valor } \\
\hline & & & IPEN & ESALQ-USP \\
\hline \multicolumn{2}{|l|}{$\mathrm{pH}_{\mathrm{KCl}}$} & & $3,7 \pm 0,0(n=2)$ & 3,7 \\
\hline \multicolumn{2}{|l|}{$\mathrm{pH}_{\mathrm{H} 2 \mathrm{O}}$} & & $4,8 \pm 0,0(n=2)$ & 4,6 \\
\hline \multirow{2}{*}{\multicolumn{2}{|c|}{$\begin{array}{l}\mathrm{pH}_{\mathrm{CaCl} 2} \\
\Delta \mathrm{pH}=\mathrm{pH}_{\mathrm{KCl}}-\mathrm{pH}_{\mathrm{H} 2 \mathrm{O}}\end{array}$}} & - & - & 3,7 \\
\hline & & & $-1,1$ & - \\
\hline \multicolumn{2}{|c|}{$\mathrm{PCZ}=2 \mathrm{pH}_{\mathrm{KCl}}-\mathrm{pH}_{\mathrm{H} 2 \mathrm{O}}$} & & 2,6 & - \\
\hline \multirow{2}{*}{\multicolumn{2}{|c|}{ MO }} & $\%$ & $2,66 \pm 0,06(n=2)$ & - \\
\hline & & $\mathrm{g} \mathrm{kg}^{-1}$ & - & 14 \\
\hline \multicolumn{2}{|l|}{ CTC } & & $72,0 \pm 0,6(n=2)$ & - \\
\hline \multicolumn{2}{|l|}{ K } & & - & 0,9 \\
\hline \multicolumn{2}{|l|}{$\mathrm{Ca}$} & & - & 2 \\
\hline \multicolumn{2}{|l|}{$M g$} & & - & 1,810 \\
\hline \multicolumn{2}{|l|}{$\mathrm{Na}$} & $\mathrm{mmol}_{\mathrm{c}} \mathrm{kg}^{-1}$ & - & 0,0 \\
\hline \multicolumn{2}{|c|}{ Al } & & - & 13 \\
\hline \multicolumn{2}{|c|}{ Acidez potencial $(\mathrm{H}+\mathrm{Al})$} & & - & 42 \\
\hline \multicolumn{2}{|c|}{ SB } & & - & 4,9 \\
\hline \multicolumn{2}{|l|}{$\mathrm{CTC}_{\mathrm{E}}$} & & & 17,9 \\
\hline \multicolumn{2}{|l|}{$\mathrm{CTC}_{\mathrm{t}}$} & & - & 46,47 \\
\hline \multicolumn{2}{|l|}{ V\% } & $\%$ & - & 10,55 \\
\hline \multicolumn{2}{|l|}{$m \%$} & $\%$ & - & 73,20 \\
\hline \multicolumn{2}{|l|}{$\mathrm{P}$} & $m a g^{-1}$ & - & 3 \\
\hline \multicolumn{2}{|l|}{$\mathrm{Si}$} & $\mathrm{mg} \mathrm{kg}^{-1}$ & - & 5 \\
\hline \multirow{4}{*}{ Óxidos } & $\mathrm{Al}_{2} \mathrm{O}_{3}$ & & 5,9 & 7,24 \\
\hline & $\mathrm{Fe}_{2} \mathrm{O}_{3}$ & $\%$ & 1,6 & 2,00 \\
\hline & $\mathrm{MnO}$ & $\%$ & $<0,0065$ & 0,0100 \\
\hline & $\mathrm{TiO}$ & & - & 3,50 \\
\hline \multicolumn{2}{|l|}{$\mathrm{SiO}_{2}$} & $\%$ & - & 4,20 \\
\hline \multirow{3}{*}{ Nitrogênio } & Total & & - & 896 \\
\hline & $\mathrm{N}-\mathrm{NO}_{3}$ & $\mathrm{mg} \mathrm{kg}^{-1}$ & - & 10 \\
\hline & $\mathrm{N}-\mathrm{NH}_{4}$ & & - & 11 \\
\hline
\end{tabular}

PCZ = ponto de carga zero; CTC = capacidade de troca catiônica; $n=$ número de amostras

Foi possível observar diferenças nos resultados obtidos nos diferentes laboratórios (IPEN e ESALQ-USP) para as determinações de matéria orgânica (MO) e capacidade de troca catiônica (CTC). As diferenças nos valores de CTC e MO podem ser atribuídas à utilização de diferentes metodologias adotadas pelos laboratórios conforme descritas na TAB.16.

$\mathrm{O} \mathrm{pH}$ da maioria dos solos tropicais é geralmente baixo, ou seja, são solos ácidos, tais como, o solo em estudo que apresentou um $\mathrm{pH}$ em $\mathrm{KCl}$ e $\mathrm{CaCl}_{2}$ igual a 3,7 (TAB.22). O valor de $\mathrm{pH}$ obtido em água foi maior do que o $\mathrm{pH}$ obtido nas soluções salinas, pois este representa a atividade de $\mathrm{H}^{+}$em solução em equilíbrio com a fase sólida do solo, denominada acidez ativa, fato que não é 
comum ocorrer com o solo em campo, já que a solução do solo é composta por vários sais dissolvidos. $\mathrm{O}$ pH em soluções salinas é considerado mais representativo, pois reflete a acidez potencial e acidez ativa do solo, ou seja, aquela referente a íons $\mathrm{H}^{+}$e $\mathrm{Al}^{+3}$ ligados aos colóides do solo e aos íons $\mathrm{H}^{+}$em equilíbrio na solução do solo. A redução do valor de $\mathrm{pH}$ com o aumento da concentração salina (força iônica da solução) pode ser interpretada pelo deslocamento de $\mathrm{H}^{+}$da superfície dos colóides e, ou, hidrólise do $\mathrm{Al}^{+3}$ deslocado (MELO e ALLEONI, 2009).

$\mathrm{O}$ pH é um dos parâmetros mais importantes na mobilidade dos elementos tóxicos no solo. Geralmente a mobilidade dos cátions metálicos aumenta conforme aumento da acidez do solo devido à dessorção de alguns metais ser favorecida, pois íons $\mathrm{H}^{+}$podem deslocar uma parte do metal adsorvido em forma não trocável, sendo que a atividade destes metais em solo é altamente dependente do pH (PIERZYNSKI et al., 1994). Entretanto, para os oxiânions essa relação já é mais variável. Os oxiânions de As e Mo tornam-se mais móveis conforme o meio torna-se mais alcalino (PIERZYNSKI et al., 1994).

A carga líquida do solo foi estimada pelo cálculo do $\Delta \mathrm{pH}$, o qual representa a distribuição de cargas elétricas no solo de acordo com MEKARU e UEHARA (1972). Foi obtido um valor de $\triangle \mathrm{pH}$ negativo (TAB.22), que corresponde a uma predominância de cargas negativas no solo, o que pode indicar que o solo é mais propício à adsorção de cátions.

Outro cálculo realizado foi o do ponto de carga zero (PCZ) do solo de acordo com KENG e UEHARA (1974), que corresponde a um valor de pH no qual a carga líquida resultante de todas fontes da superfície de um colóide reduz-se a zero (MELO et al., 2009). O PCZ calculado foi 2,6 (TAB.22), ou seja, o PCZ do solo é menor que o $\mathrm{pH}_{\mathrm{KCl}}$ do solo $(3,7)$. Em solos com valores de $\mathrm{pH}$ acima do PCZ predominam as cargas negativas sejam elas permanentes (associadas com substituições isomórficas) e/ou variáveis (associadas com superfícies hidroxiladas de colóides) (MELO e ALLEONI, 2009). Como o solo em estudo apresentou um $\mathrm{pH}_{\mathrm{kCl}}$ igual a 3,7 que é maior que o PCZ $(2,6)$ este tende a atrair cargas positivas (cátions). 
As ligações entre os cátions trocáveis $\left(\mathrm{Na}^{+}, \mathrm{K}^{+}, \mathrm{Ca}^{2+}, \mathrm{Mg}^{2+}\right.$ e $\left.\mathrm{Al}^{3+}\right)$ e os sítios de troca no solo possuem caráter predominantemente eletrostático. Esses cátions podem estar envolvidos em reações de troca iônica com os elementos tóxicos em estudo. Os resultados da TAB.22 indicaram que essas reações podem ocorrer preferencialmente com os cátions bivalentes, $\mathrm{Ca}$ e Mg, e principalmente nos sítios de alumínio trocável, já que a quantidade desses elementos apresentou-se na seguinte ordem decrescente: $\mathrm{Al}>>>\mathrm{Ca}>\mathrm{Mg}>\mathrm{K}$.

A capacidade de troca catiônica (CTC) medida foi de $72,0 \mathrm{mmol}_{\mathrm{c}} \mathrm{kg}^{-1}$ (TAB.22). Em termos quantitativos, a CTC é definida como a quantidade de cátions que são adsorvidos reversivelmente por unidade de massa seca do material e ocorre de maneira que a superfície dos sólidos consiga manter a eletroneutralidade. O valor determinado está coerente com valores de CTC determinados para solos brasileiros de acordo com MELFI et al. (2004), conforme exposto na FIG.21.

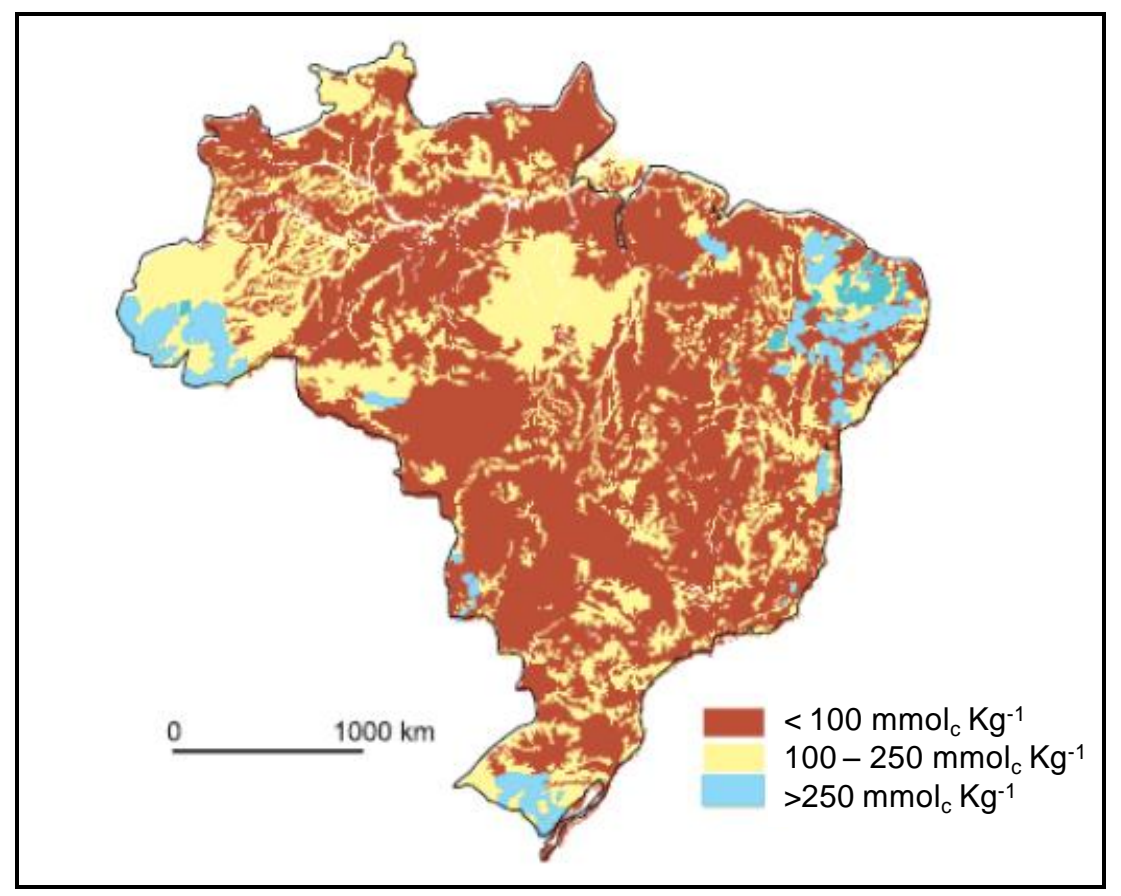

FIGURA 21 - Distribuição dos valores de CTC dos solos no Brasil (Fonte: MELFI et al., 2004)

O valor de CTC obtido para o solo em estudo é considerado baixo quando comparado a solos constituídos por argilominerais do tipo 2:1, nos quais a CTC pode alcançar valores de até $1500 \mathrm{mmol}_{\mathrm{C}} \mathrm{kg}^{-1}$ (SPOSITO, 1989), mas que 
são raramente encontrados em solos brasileiros. Em solos brasileiros predominam argilominerais do tipo 1:1, tais como a caulinita que tem uma CTC de 30 a $100 \mathrm{mmol}_{\mathrm{c}} \mathrm{kg}^{-1}$ e principalmente os óxidos de $\mathrm{Fe}$ e Al (MELO e ALLEONI, 2009).

A CTC é um indicativo potencial do solo na adsorção de elementos tóxicos, porém outros fatores como a seletividade do metal, concentração de outros cátions, $\mathrm{pH}$ e atividade iônica da solução devem ser considerados (NOGUEIROL, 2008).

De acordo com MCBRIDE (1994) a matéria orgânica auxilia na retenção de água no solo, na retenção de nutrientes por troca iônica, na liberação de nitrogênio, fósforo, enxofre e elementos traços por mineralização e na adsorção de elementos potencialmente tóxicos.

Solos minerais bem drenados tem teor de matéria orgânica variando entre 2 e 6\%. O solo em estudo apresentou um teor de 2,66\% (TAB.22) e pode ser classificado como um solo de baixa porcentagem de matéria orgânica (BRADY, 1989). Em solos tropicais que sofreram intensa ação do intemperismo, mesmo pequenas percentagens de matéria orgânica podem elevar a CTC do solo.

Essa CTC elevada, relacionada à matéria orgânica, envolve principalmente os grupos funcionais orgânicos. Estes grupos podem atuar como doadores ou receptores de elétrons e por isso podem afetar a mobilização de cátions metálicos na solução do solo e ainda podem agir como agentes tamponantes do solo (YONG e MULLIGAN, 2004).

Os resultados mostraram a presença de óxidos de $\mathrm{Fe}, \mathrm{Al}$ e $\mathrm{Mn}$ no solo (TAB.22). Solos localizados em regiões tropicais, como o solo em estudo, são geralmente solos que sofreram intensa intemperização, na qual ocorre o processo de dessilicatização, com resultante acúmulo de óxidos insolúveis, como os de Fe, Al e Mn, além de caulinita (MELO e ALLEONI, 2009). SCHWERTMANN et al. (1986) descreveram que em solos com baixos teores de matéria orgânica, a 
formação de Goethita $(\mathrm{FeOOH})$ e Hematita $\left(\mathrm{Fe}_{2} \mathrm{O}_{3}\right)$ é favorecida, pois em altos teores de $\mathrm{MO}$ grande parte do ferro é complexado.

Diferentemente do que ocorre nos argilominerais, esses óxidos e hidróxidos não tendem a sofrer substituições isomórficas e por isso possuem baixa capacidade de troca cationica, apesar de terem, em muitos casos, uma alta área superficial específica. Todavia, essa superfície pode adquirir cargas com a variação do pH da solução do solo (MCBRIDE, 1994).

A geração de cargas positivas nesses óxidos pode estar associada aos radicais $\mathrm{OH}^{-}$presentes em suas extremidades que podem ser dissociados $\left(\mathrm{O}^{-}\right)$ou protonados $\left(\mathrm{OH}_{2}{ }^{+}\right)$dependendo do $\mathrm{pH}$, conforme exposto na FIG.22. Como o PCZ desses compostos é normalmente elevado, predominam em solos ácidos as cargas positivas nos mesmos (MELO e ALLEONI, 2009). A presença de cargas positivas nesses óxidos pode favorecer a retenção de ânions no solo.

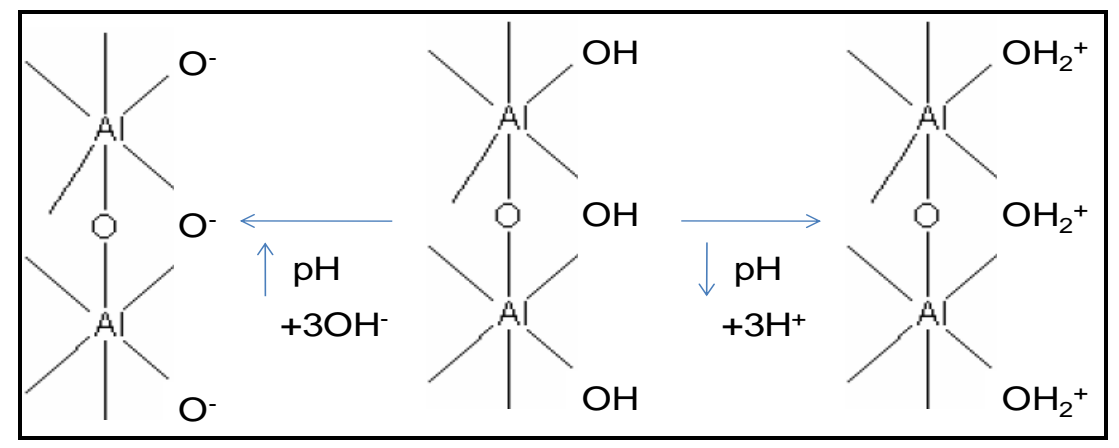

FIGURA 22 - Exemplo de geração de cargas variáveis na superfície dos óxidos de alumínio e ferro (Fonte: MELO e ALLEONI, 2009)

\subsubsection{Caracterização mineralógica do solo não lixiviado}

A mineralogia do solo foi determinada por difratometria de raios-X que indicou a presença das fases cristalinas quartzo $\left(\mathrm{SiO}_{2}\right)$, gibbsita $\left(\mathrm{Al}(\mathrm{OH})_{3}\right)$, anatásio $\left(\mathrm{TiO}_{2}\right)$, caulinita $\left(\mathrm{Al}_{2} \mathrm{Si}_{2} \mathrm{O}_{5}(\mathrm{OH})_{4}\right)$ e possível presença de hematita $\left(\mathrm{Fe}_{2} \mathrm{O}_{3}\right)$ conforme exposto na FIG.23. 


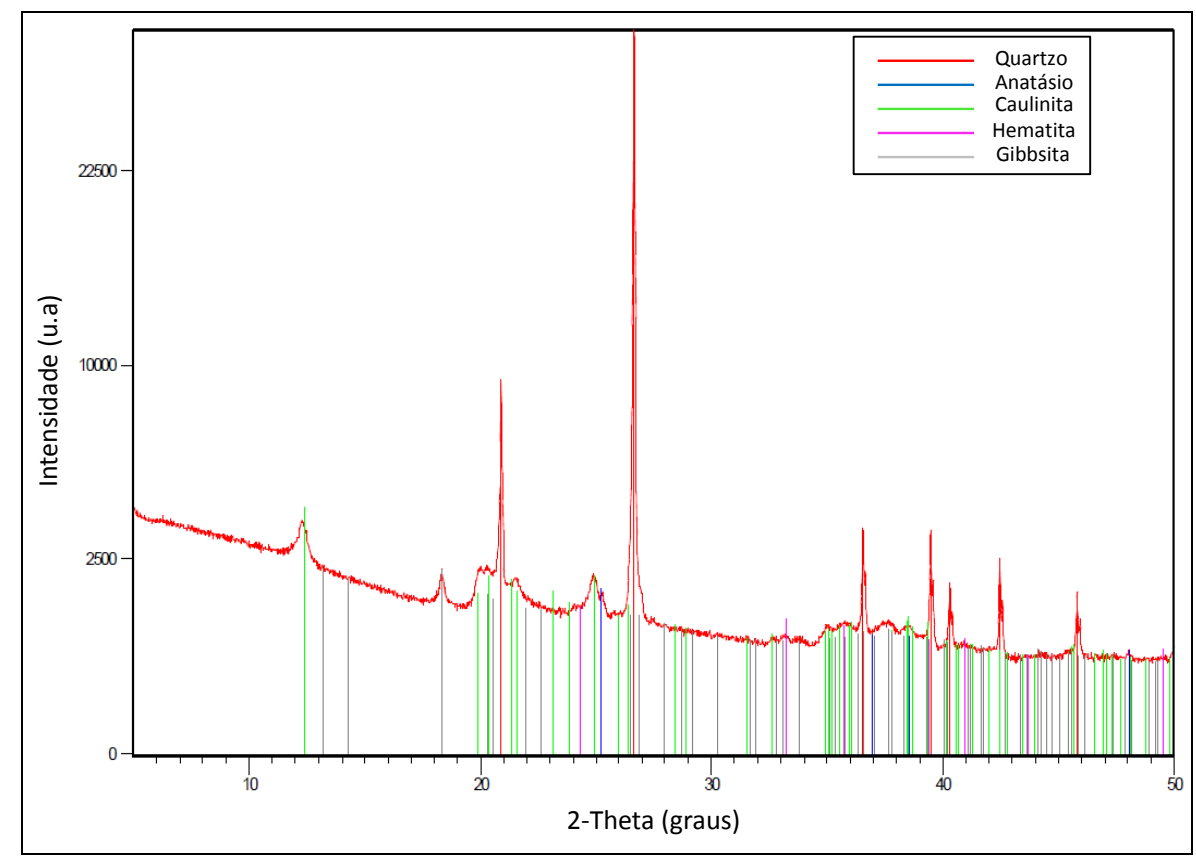

FIGURA 23 - Difratograma do solo obtido no LCT-POLI-USP

Esses minerais são de ocorrência frequente em solos intemperizados (SOARES, 2004). SOARES (2004) analisou a mineralogia de solos na região de coleta do solo utilizado no presente estudo e também observou a presença de goethita $(\mathrm{FeOOH})$, não observada na FIG.25. O autor adotou procedimento em que separou a fração argilosa e a fração óxidos por distintos métodos de fracionamento para obter tal resultado, ao passo que no presente trabalho, a argila foi separada apenas por separação granulométrica com auxílio de um conjunto de peneiras.

Outro indicativo da possível presença de goethita foi o resultado obtido para a cor do solo. A cor da amostra de solo foi determinada pela carta de Munsell e o resultado obtido foi 6,25 YR 4/3 (item 5.2.1), ou seja, o solo foi classificado como vermelho-amarelo. De acordo com KÄMPF e SCHWERTMANN (1983)

- resultado encontrado indicou um quociente Hematita/Hematita+Goethita<0,4 que classifica o solo como caulinítico goethítico.

$\mathrm{Na}$ caracterização de solos, o índice $\mathrm{Ki}$, calculado pela equação $\mathbf{1 8}$, fornece uma indicação do grau de alteração ou intemperismo de solos tropicais. 
$\mathrm{Ki}=1,7 \frac{\mathrm{SiO}_{2}}{\mathrm{Al}_{2} \mathrm{O}_{3}}$

Aplicando os valores dos óxidos de Al e Si da TAB.22 na equação 18 o valor de $K_{i}$ calculado foi igual a 1,20. De acordo com RESENDE et al. (1998) solos com valores de $\mathrm{K}_{\mathrm{i}}>0,75$ são solos com predominância de argila silicatada do tipo 1:1, tal qual a caulinita. A EMBRAPA (1999) adota outro índice na caracterização de solos, o índice Kr, calculado pela equação 19.

$$
\mathrm{Kr}=1,7 \frac{\mathrm{SiO}_{2}}{\mathrm{Al}_{2} \mathrm{O}_{3}+0,64 \mathrm{Fe}_{2} \mathrm{O}_{3}}
$$

Aplicando os valores dos óxidos de Al, Si e Fe da TAB.22 na equação 19 o valor de $\mathrm{Kr}$ calculado foi igual a 1,00, valor que de acordo com a EMBRAPA (1999) caracteriza o solo como caulinítico $(\mathrm{Kr}>0,75)$. Tais resultados estão de acordo com a difratometria de raios-X (FIG.23) na qual foi identificada a presença de caulinita no solo.

\subsubsection{Caracterização química do solo lixiviado}

$\mathrm{O} \mathrm{pH}$ e os óxidos de $\mathrm{Al}$, Fe e Mn foram determinados no solo após lixiviação das colunas de solo com objetivo de se avaliar possível alteração dessas propriedades químicas, uma vez que elas estão relacionadas com a mobilidade dos elementos tóxicos no solo. Os óxidos foram determinados devido à observação no percolado das colunas de solo e solo+cinza uma coloração marrom com partículas que tinham aspecto de hidróxido de ferro III (FIG.24). A solubilização e ou a lixiviação dessas partículas poderia ocasionar alterações na mobilidade dos elementos ligados a eles. 


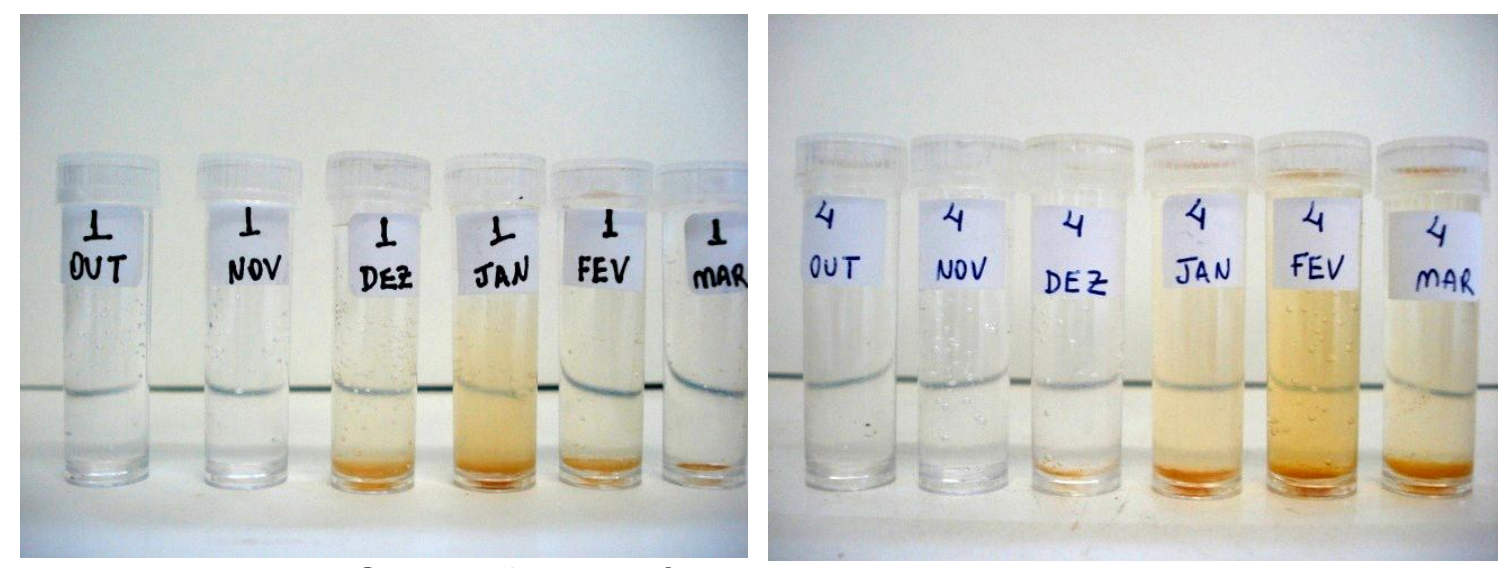

FIGURA 24 - Coloração e partículas nos percolados das colunas de solo e solo+cinza

$\mathrm{Na}$ TAB.23 foi exposto o $\mathrm{pH}$ do solo após os dois períodos de lixiviação, 168 e 336 dias.

TABELA 23 - $\mathrm{pH}_{\mathrm{KCl}}, \mathrm{pH}_{\mathrm{H} 2 \mathrm{O}}$ e $\Delta \mathrm{pH}$ do solo após lixiviação

\begin{tabular}{ccccc}
\hline $\begin{array}{c}\text { Período de } \\
\text { Lixiviação }\end{array}$ & Coluna & $\begin{array}{c}\mathbf{p H}(\mathrm{KCl}) \\
(\mathbf{n}=\mathbf{4})\end{array}$ & $\begin{array}{c}\mathbf{p H}\left(\mathrm{H}_{2} \mathbf{O}\right) \\
(\mathbf{n}=4)\end{array}$ & $\boldsymbol{\Delta} \mathbf{p H}$ \\
\hline \multirow{2}{*}{168 dias } & Solo & $4,0 \pm 0,0$ & $4,5 \pm 0,0$ & $-0,5$ \\
& Solo + Cinza & $4,3 \pm 0,1$ & $5,3 \pm 0,0$ & $-1,0$ \\
\hline \multirow{2}{*}{336 dias } & Solo & $4,1 \pm 0,1$ & $4,5 \pm 0,0$ & $-0,4$ \\
& Solo + Cinza & $4,3 \pm 0,0$ & $5,2 \pm 0,1$ & $-0,9$ \\
\hline
\end{tabular}

$\Delta \mathrm{pH}=\mathrm{pH}_{\mathrm{KCl}}-\mathrm{pH}_{\mathrm{H} 2 \mathrm{O}} ; \mathrm{n}=$ número de amostras

Os resultados mostraram que não houve diferença representativa entre os valores obtidos para as colunas de solo lixiviadas durante 168 e 336 dias.

Observou-se que o $\mathrm{pH}_{\mathrm{KCl}}$ do solo lixiviado $(4,1 \pm 0,1$ (TAB.23)) aumentou ligeiramente em relação ao $\mathrm{pH}$ determinado antes da lixiviação $\left(\mathrm{pH}_{\mathrm{KCl}}\right.$ 3,7 (TAB.22)). Aquele pH é próximo ao pH da solução simuladora de chuva, 4,5, indicando que o $\mathrm{pH}$ do solo foi ligeiramente influenciado pela solução de entrada na coluna. $\mathrm{O} \Delta \mathrm{pH}$ do solo variou com a lixiviação do solo, passando de $-1,1$ (TAB.22) para -0,4 (TAB.23), indicando que houve uma diminuição da influência das cargas negativas no solo, diminuindo a capacidade desse solo em reter cátions. 
Para o solo da coluna solo+cinza, o $\mathrm{pH}_{\mathrm{KCl}}$ do solo após lixiviação foi 4,3 (TAB.23), ou seja, também aumentou ligeiramente em relação ao $\mathrm{pH}_{\mathrm{KCl}}$ do solo antes da lixiviação (3,7 (TAB.22)). A cinza de carvão possui um $\mathrm{pH}_{\mathrm{H} 2 \mathrm{O}}$ mais elevado (7,4 (TAB.19)) que a solução simuladora de chuva ácida, $\mathrm{pH} 4,5$. Isso pode ter ocasionado a entrada de uma solução na coluna de solo com um pH mais elevado, que será discutido posteriormente. $\mathrm{O} \Delta \mathrm{pH}$ do solo não variou representativamente com a lixiviação do solo com a cinza, passando de $-1,1$ (TAB.22) para -0,9 (TAB.23).

Os resultados indicaram que $\mathrm{opH}$ do solo, com ou sem cinza, permanece ácido mesmo após a lixiviação.

Na TAB.24 foi mostrada a média dos resultados dos óxidos de Al, Fe e Mn determinados no solo das colunas após lixiviação.

TABELA 24 - Porcentagem dos óxidos $\mathrm{Al}_{2} \mathrm{O}_{3}, \mathrm{Fe}_{2} \mathrm{O}_{3}$ e $\mathrm{MnO}$ no solo após lixiviação

\begin{tabular}{ccccc}
\hline Período de Lixiviação & Coluna & $\begin{array}{c}\% \mathrm{Al}_{2} \mathrm{O}_{3} \\
(\mathbf{n = 2})\end{array}$ & $\begin{array}{c}\% \mathrm{Fe}_{2} \mathbf{O}_{3} \\
(\mathbf{n = 2})\end{array}$ & $\begin{array}{c}\% \mathrm{MnO} \\
(\mathbf{n}=\mathbf{2})\end{array}$ \\
\hline \multirow{2}{*}{168 dias } & Solo & $5,67 \pm 0,07$ & $1,41 \pm 0,01$ & $0,0146 \pm 0,0001$ \\
& Solo + Cinza & $5,41 \pm 0,03$ & $1,37 \pm 0,00$ & $0,0144 \pm 0,0001$ \\
\hline \multirow{2}{*}{336 dias } & Solo & $5,93 \pm 0,10$ & $1,49 \pm 0,03$ & $0,0148 \pm 0,0001$ \\
& Solo + Cinza & $5,24 \pm 0,07$ & $1,32 \pm 0,01$ & $0,0139 \pm 0,0000$ \\
\hline
\end{tabular}

n=número de amostras

Os resultados mostraram que não houve diferença representativa entre os valores obtidos para as colunas lixiviadas durante 168 e 336 dias, dessa maneira, a média desses resultados para cada tipo de coluna foi comparada com os resultados obtidos no solo não lixiviado (TAB.22), conforme exposto na FIG.25. 


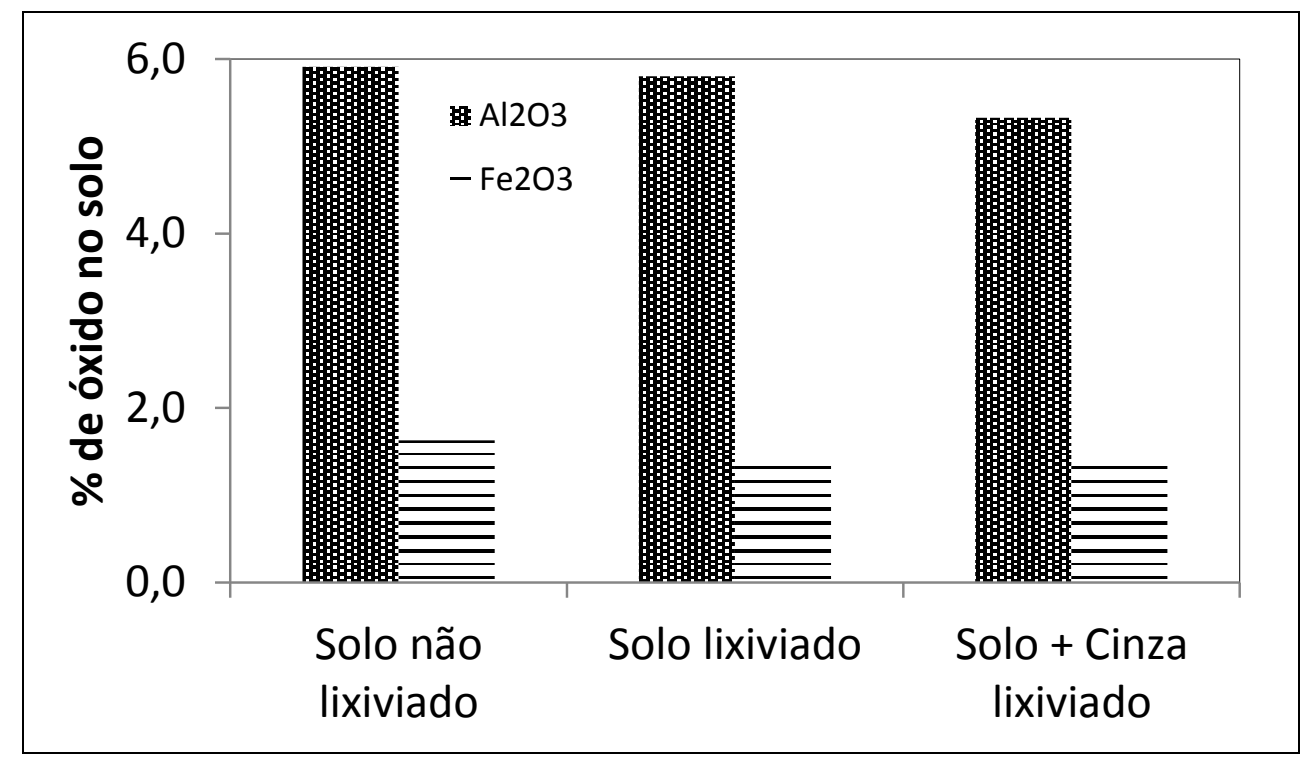

FIGURA 25 - Porcentagem de óxidos de Fe e Al nas amostras de solo

Na FIG.25 foi observado que houve uma ligeira redução no percentual dos óxidos de alumínio e ferro no solo devido a lixiviação tanto nas colunas de solo como nas colunas de solo+cinza quando comparada com o do solo não lixiviado, porém essa ligeira redução não foi representativa.

O MnO não foi considerado na FIG.25, pois a \% deste óxido no solo não lixiviado (TAB.22) foi abaixo do limite de quantificação do método.

\subsection{Percolado das colunas}

\subsubsection{Caracterização química dos percolados}

Os percolados gerados pela lixiviação das colunas foram caracterizados mensalmente quanto ao $\mathrm{pH}$, condutividade elétrica e carbono dissolvido. Além disso, esses percolados também foram caracterizados mensalmente quanto à concentração de $\mathrm{Al}, \mathrm{Fe}$ e $\mathrm{Mn}$, ânions $\left(\mathrm{SO}_{4}{ }^{2-}, \mathrm{NO}_{3}{ }^{-}, \mathrm{F}^{-}, \mathrm{Cl}^{-}\right.$, $\mathrm{NO}_{2}^{-}$e $\mathrm{PO}_{4}{ }^{3-}$ ) e elementos majoritários ( $\mathrm{Na}, \mathrm{Mg}, \mathrm{Si}, \mathrm{K}$ e $\mathrm{Ca}$ ), conforme será abordado no subitens apresentados a seguir.

Essas propriedades foram determinadas visando-se estabelecer correlação dessas com a concentração dos elementos As, Cd, Mo, Pb e Zn, bem como, simular a especiação desses elementos no modelo PHREEQC para auxiliar na compreensão da mobilidade dos elementos tóxicos no solo. 


\subsubsection{1. $\quad$ pH dos percolados}

As médias das medidas de $\mathrm{pH}$ dos percolados das colunas ao longo de 336 dias foram ilustradas na FIG.26.

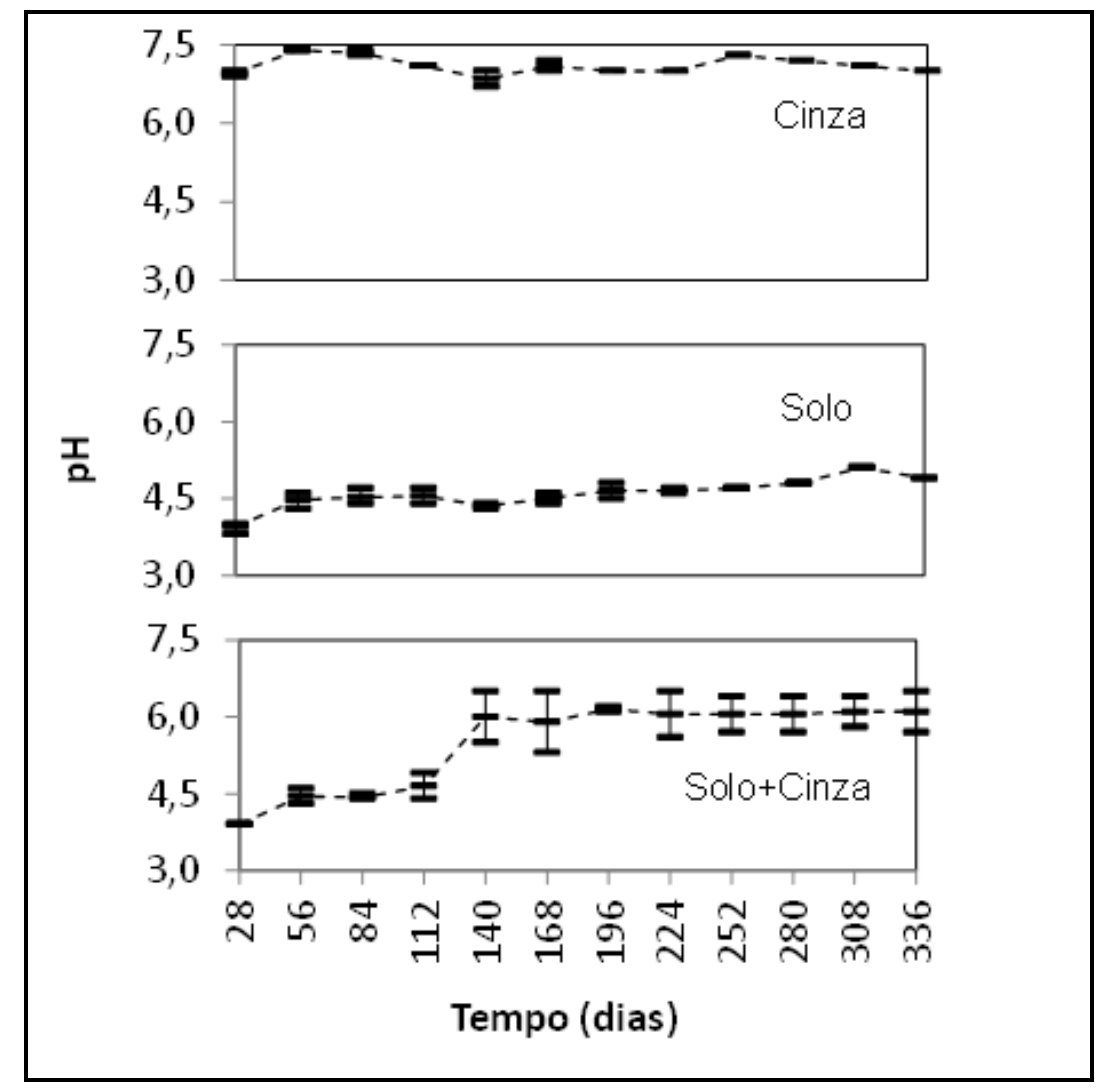

FIGURA 26 - pH dos percolados das colunas lixiviadas ao longo de 336 dias

Esses resultados mostraram que $0 \mathrm{pH}$ dos percolados gerados nas colunas de cinza de carvão foi pouco influenciado pelo pH 4,5 da solução simuladora de chuva ácida, ou seja, esses percolados apresentaram valores de pH próximos do valor obtido para a cinza de carvão não lixiviada $\left(7,4\left(\mathrm{pH}_{\mathrm{H} 2 \mathrm{O}}\right)\right)$, indicando que esse material possui boa capacidade tamponante.

Os percolados gerados pela lixiviação das colunas de solo apresentaram valores de $\mathrm{pH}$ (FIG.26) próximos ao valor do $\mathrm{pH}_{\mathrm{KCl}}$ do solo não lixiviado (3,7 (TAB.22)), principalmente no primeiro mês de lixiviação e foi se aproximando do $\mathrm{pH}(4,5)$ da solução simuladora de chuva ao longo do tempo. Observou-se que nos últimos tempos de lixiviação o pH aumentou ligeiramente. 
Os percolados gerados pela lixiviação das colunas de solo com a cinza de carvão apresentaram valores de $\mathrm{pH}$ próximos dos valores obtidos para os percolados das colunas de solo (solo sem cinza) até 112 dias de lixiviação (FIG.26). Esse fato pode ser explicado pela capacidade tamponante do solo em estudo. Nos tempos de lixiviação seguintes o pH dos percolados apresentaram valores mais elevados, tendendo a uma aproximação do $\mathrm{pH}$ do percolado da cinza de carvão.

Na FIG.27 foi ilustrada a variação do $\mathrm{pH}$ no sistema de lixiviação das colunas de solo, solo+cinza e cinza.

\begin{tabular}{|c|c|c|c|c|c|}
\hline $\mathrm{pH}=4,5$ & $\begin{array}{l}\Delta \Delta \Delta C \\
\Delta \Delta \Delta\end{array}$ & $\begin{array}{l}\Delta \triangleleft \delta \\
\Delta \triangleleft \\
\text { CINZA }\end{array}$ & $\begin{array}{l}\longrightarrow \mathrm{pH}=4,5 \\
\longrightarrow \mathrm{pH}=7,4\end{array}$ & $\begin{array}{l}\Delta \Delta \Delta \\
\Delta \Delta\rangle \\
\text { CINZA }\end{array}$ & $\begin{array}{l}\longrightarrow \mathrm{pH}=4,5 \\
\longrightarrow \mathrm{pH}=7,4\end{array}$ \\
\hline $\begin{array}{l}\mathrm{pH}_{0 \text { dia }}=3,7 \\
\mathrm{pH}_{168 \text { dias }}=4,0 \\
\mathrm{pH}_{336 \text { dias }}=4,1\end{array}$ & SOLO & SOLO & $\begin{aligned} \mathrm{pH}_{0 \text { dia }} & =3,7 \\
\mathrm{pH}_{168 \text { dias }} & =4,3 \\
\mathrm{pH}_{336 \text { dias }} & =4,3\end{aligned}$ & $\begin{array}{c}\text { AREIA } \\
\text { INERTE }\end{array}$ & \\
\hline $\begin{array}{l}\mathrm{pH}_{28 \text { dias }}=4,0 \\
\mathrm{pH}_{168 \text { dias }}=4,5 \\
\mathrm{pH}_{336 \text { dias }}=4,9\end{array}$ & & & $\begin{array}{l}\mathrm{pH}_{28 \text { dias }}=3,9 \\
\mathrm{pH}_{168 \text { dias }}=5,9 \\
\mathrm{pH}_{336 \text { dias }}=6,1\end{array}$ & & $\begin{array}{l}\mathrm{pH}_{28 \text { dias }}=7,0 \\
\mathrm{pH}_{168 \text { dias }}=7,1 \\
\mathrm{pH}_{336 \text { dias }}=7,0\end{array}$ \\
\hline
\end{tabular}

FIGURA 27 - Variação do pH no sistema de lixiviação das colunas

Conforme exposto na FIG.27, pôde-se notar que a deposição da cinza de carvão no topo das colunas de solo causou uma pequena alteração do $\mathrm{pH}$ do solo, como já foi discutido no item 5.2.3. No pH do percolado da coluna de solo+cinza, essa alteração foi maior, variando de 3,9 no início da lixiviação para 6,1 após 336 dias. Isso indica que se a cinza de carvão for disposta inadequadamente no solo $\mathrm{o} \mathrm{pH}$ da solução do solo poderia ser alterado e consequentemente o da água subterrânea também.

\subsubsection{Condutividade elétrica dos percolados}

As médias das leituras de condutividade elétrica dos percolados das colunas ao longo de 336 dias foram ilustradas na FIG.28. 


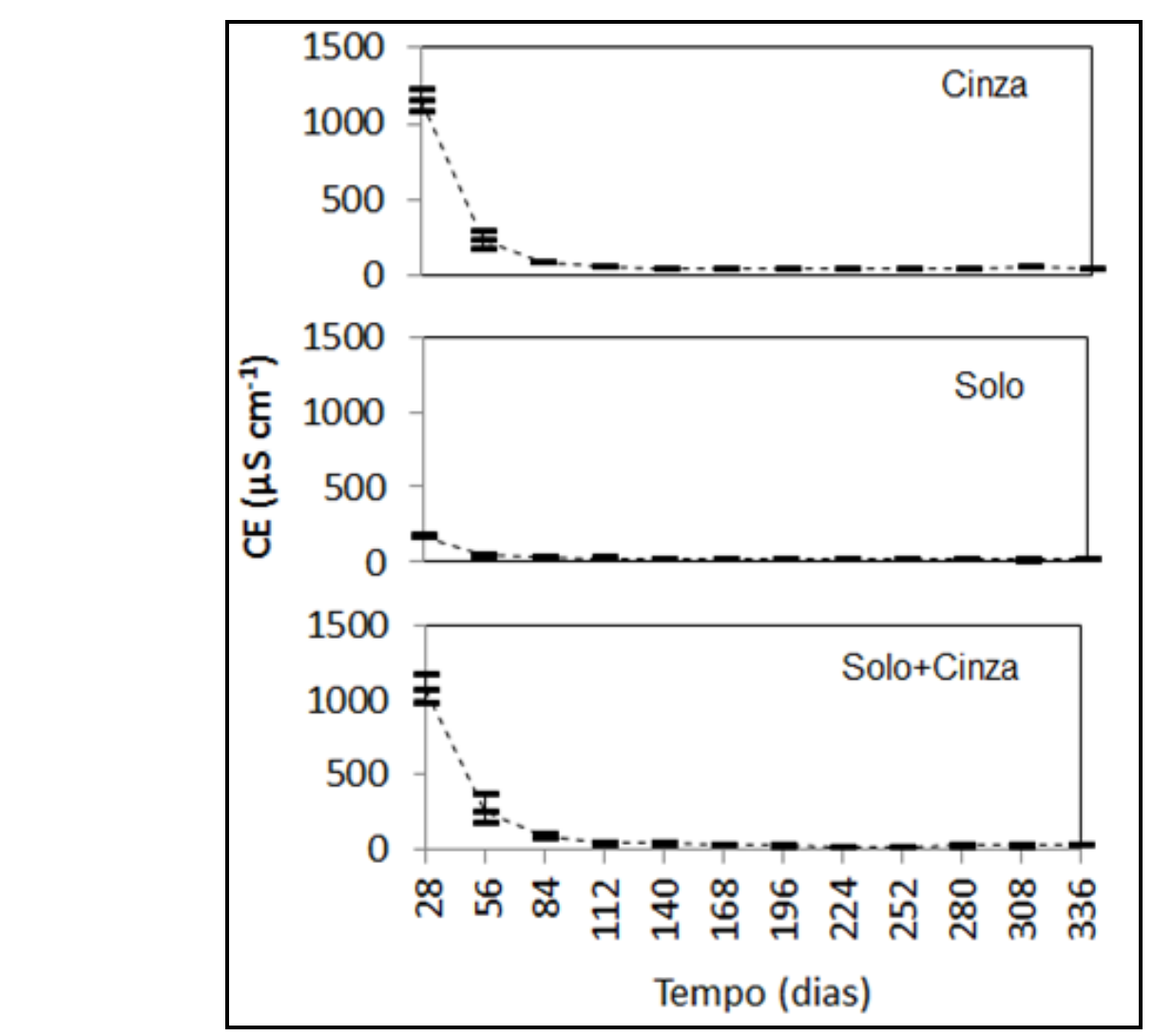

FIGURA 28 - Condutividade elétrica dos percolados das colunas lixiviadas ao longo de 336 dias

A condutividade elétrica é uma medida direta de íons na solução. Quanto menor a quantidade de íons menor a condutividade, e quanto maior for a quantidade de íons maior será a condutividade. Logo a quantidade de íons presentes na solução é proporcional a condutividade elétrica. Os resultados da FIG.28 mostraram que os percolados das colunas de cinza e solo+cinza apresentaram valores de condutividade elétrica muito superiores àqueles observados para os percolados das colunas de solo nos dois primeiros tempos de lixiviação. Entretanto, observou-se que esses valores são mais próximos a partir de 112 dias de lixiviação.

\subsubsection{Concentração de CTD, COD e CID dos percolados}

As concentrações de carbono orgânico dissolvido (COD), carbono inorgânico dissolvido (CID) e carbono total dissolvido (CTD) foram determinadas mensalmente no percolado das colunas. Os resultados das médias das 
concentrações de CTD, COD e CID dos percolados das colunas e o volume dos percolados ao longo 336 dias foram expostos na FIG.29.

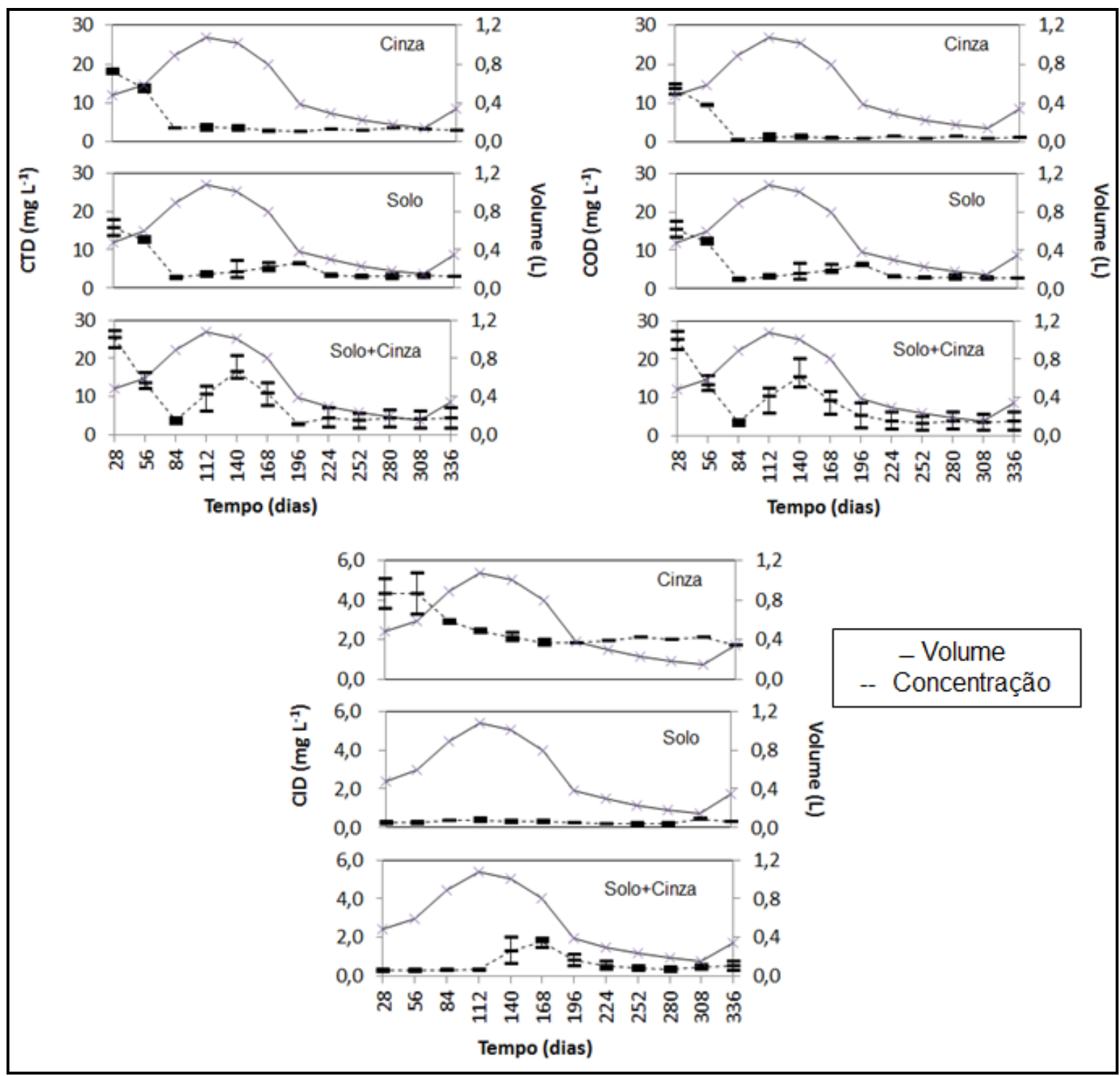

FIGURA 29 - Concentração de carbono total dissolvido (CTD), carbono orgânico dissolvido (COD), carbono inorgânico dissolvido (CID) e volume dos percolados das colunas lixiviadas ao longo de 336 dias

Foi observado na FIG.29 que no percolado de todas as colunas a concentração de COD foi maior que a de CID, ou seja, o carbono orgânico do solo foi mais lixiviado do que o carbono inorgânico. A concentração de COD e CID no percolado das colunas de solo+cinza foi superior daquela encontrada nas colunas de solo. Isso indicou que a cinza influenciou na liberação do carbono orgânico e inorgânico do solo. 
Os resultados da FIG.29 mostraram que nos percolados das colunas de cinza e de solo o CTD apresentou comportamento similar ao COD, ou seja, uma maior liberação de carbono para o percolado nos primeiros 56 dias de lixiviação, seguida de concentrações menores no percolado nos demais tempos de lixiviação. Nas colunas de solo+cinza o comportamento de CTD e COD também foi similar, mas com variações da concentração do carbono no percolado até os 196 dias de lixiviação e a partir deste tempo de lixiviação a concentração de carbono diminuiu.

A curva da variação da concentração de CID, CTD e COD seguiu comportamento proporcional ao volume dos percolados das colunas de solo+cinza, da seguinte forma: a partir dos 84 dias de lixiviação para CTD e COD e a partir de 168 dias para CID.

A concentração de CID nos percolados das colunas de cinza diminuiu ao longo do tempo (FIG.29), porém de maneira mais gradual daquela observada para COD e CTD.

De acordo com HAMON et al. (2007) a fase orgânica sólida do solo pode conter substâncias húmicas solúveis que são móveis e podem transportar elementos tóxicos da fase sólida para a fase líquida do solo. Ainda de acordo com esses autores o pH é a variável mais importante nesse processo de lixiviação da fase sólida da matéria orgânica do solo, sendo que essa solubilização é proporcional ao aumento do $\mathrm{pH}$. É interessante observar que a concentração do COD aumentou no percolado das colunas de solo+cinza em 140 dias de lixiviação quando $\mathrm{o} \mathrm{pH}$ do percolado passou de 4,6 (112 dias de lixiviação) para 6,0 (FIG.26). Essa observação é coerente com o que foi descrito neste parágrafo. Correlacionando-se os dados da concentração de CTD com os valores de $\mathrm{pH}$ dos percolados das colunas de solo+cinza, foi obtida uma correlação negativa de $r=$ 0,61 , valor que está de acordo com o descrito anteriormente nesse parágrafo.

Diversos autores relatouram a afinidade de $\mathrm{Zn}$ e $\mathrm{Cd}$ em formar complexos solúveis com a matéria orgânica dissolvida (ALMAS et al., 2004; MARTINEZ et al., 2003; MCBRIDE, 1994). A mobilidade dos elementos em forma 
de oxiânions, tais como, As e Mo, tende aumentar devido à presença da matéria orgânica dissolvida, pois essa compete pelos mesmos sítios de sorção desses ânions na fase mineral do solo (HAMON et al., 2007; ISKANDAR e KIRKHAN, 2001).

De acordo com ISKANDAR e KIRKHAN (2001), que estudaram a sorção de Mo em goethita pura e goethita recoberta com COD, a sorção desse elemento diminuiu na goethita recoberta com COD devido à redução na porosidade na superfície do óxido de ferro.

\subsubsection{Concentração de Al, Fe e Mn nos percolados}

As concentrações de $\mathrm{Al}, \mathrm{Fe}$ e $\mathrm{Mn}$ no percolado das colunas foram determinadas, pois diversos autores relatouram a importância dos óxidos hidratados na fase sólida do solo nos processos de adsorção dos elementos (MELO e ALLEONI, 2009; GOLDBERG et al., 2007; ALLOWAY, 1990).

\subsubsection{Concentração de alumínio nos percolados}

As médias das concentrações de alumínio nos percolados das colunas ao longo de 336 dias foram ilustradas na FIG.30.

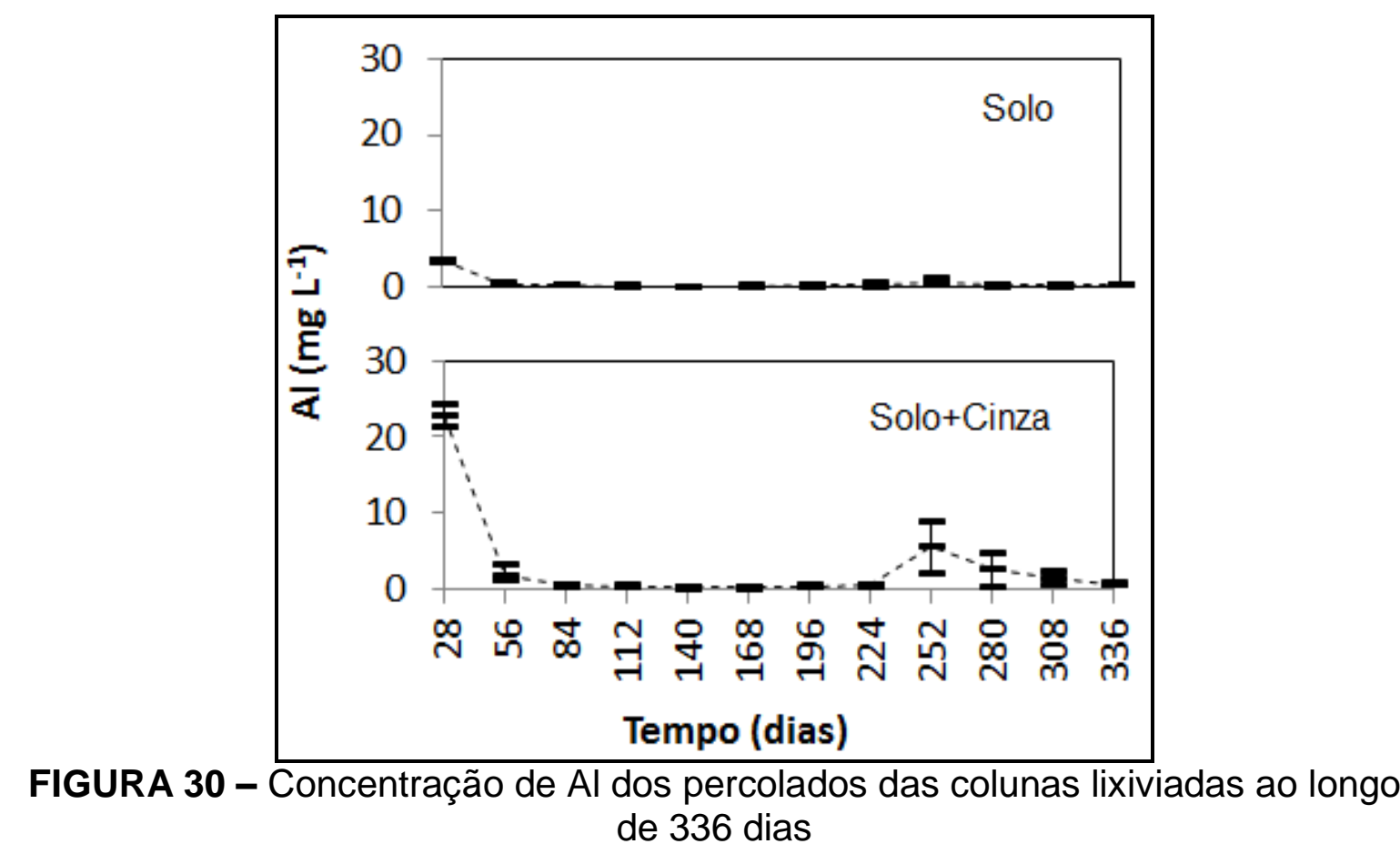


O Al é o segundo elemento em maior quantidade na cinza de carvão (TAB.18), porém não foi detectado em quantidades acima do limite de quantificação do método nos percolados das colunas de cinza de carvão, ou seja, - Al não foi lixiviado da cinza. No entanto, o elemento foi quantificado nos percolados das colunas de solo e solo+cinza, conforme exposto na FIG.30.

A solubilidade dos óxidos de alumínio é dependente do $\mathrm{pH}$ do solo e o pH dos percolados das colunas de solo e solo+cinza (FIG.26) nos três primeiros tempos de lixiviação apresentou-se em meio ácido, pH entre 4,0 e 4,5. O íon alumínio presente no solo em meio ácido, pode estar tanto na forma de acidez potencial ( $\mathrm{Al}^{+3}$ ligado aos colóides) quanto como íon solúvel na solução do solo. $\mathrm{O}$ $\mathrm{Al}^{+3}$ pode sofrer reações de troca com os íons $\mathrm{H}^{+}$e cátions em solução de forma a ser liberado para a solução do solo. À medida que o pH aumenta, esse íon pode sofrer hidrólise e gerar o composto insolúvel $\mathrm{Al}(\mathrm{OH})_{3}$ (QUAGGIO, 2000).

\subsubsection{Concentração de ferro nos percolados}

As médias das concentrações de ferro nos percolados das colunas ao longo de 336 dias de lixiviação foram ilustradas na FIG.31.

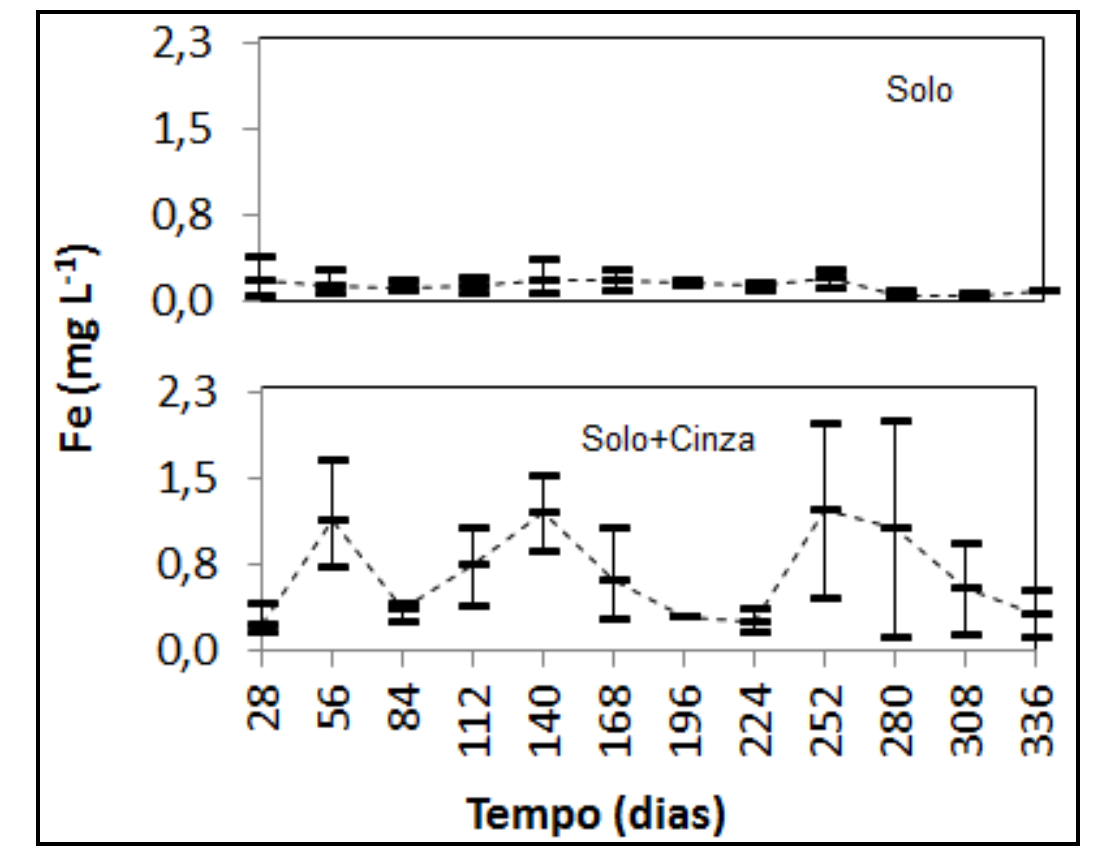

FIGURA 31 - Concentração de Fe dos percolados das colunas lixiviadas ao longo de 336 dias 
O ferro é o terceiro elemento mais abundante na cinza de carvão (TAB.18), porém não foi detectado em quantidades acima do limite de quantificação do método nos percolados das colunas de cinza de carvão, ou seja, como o $\mathrm{Al}$, o Fe também não foi lixiviado da cinza. No entanto, o elemento foi quantificado nos percolados das colunas de solo e solo+cinza, conforme exposto na FIG.31.

A influência da cinza de carvão na liberação do ferro presente no solo pode estar associada à alteração do $\mathrm{pH}$ do meio. A solubilidade dos óxidos de ferro em solo depende do pH. SPOSITO (1990) relatou que em solos ácidos as formas mais comuns de ferro na solução do solo são $\mathrm{Fe}^{2+}, \mathrm{FeSO}_{4}{ }^{0}, \mathrm{FeH}_{2} \mathrm{PO}_{4}{ }^{+}$, $\mathrm{Fe}^{3+}, \mathrm{Fe}(\mathrm{OH})_{2}{ }^{+}, \mathrm{Fe}(\mathrm{OH})_{3}{ }^{0}$ e ligado a complexos orgânicos.

\subsubsection{Concentração de manganês nos percolados}

As médias das concentrações de manganês nos percolados ao longo de 336 dias de lixiviação foram ilustradas na FIG.32.

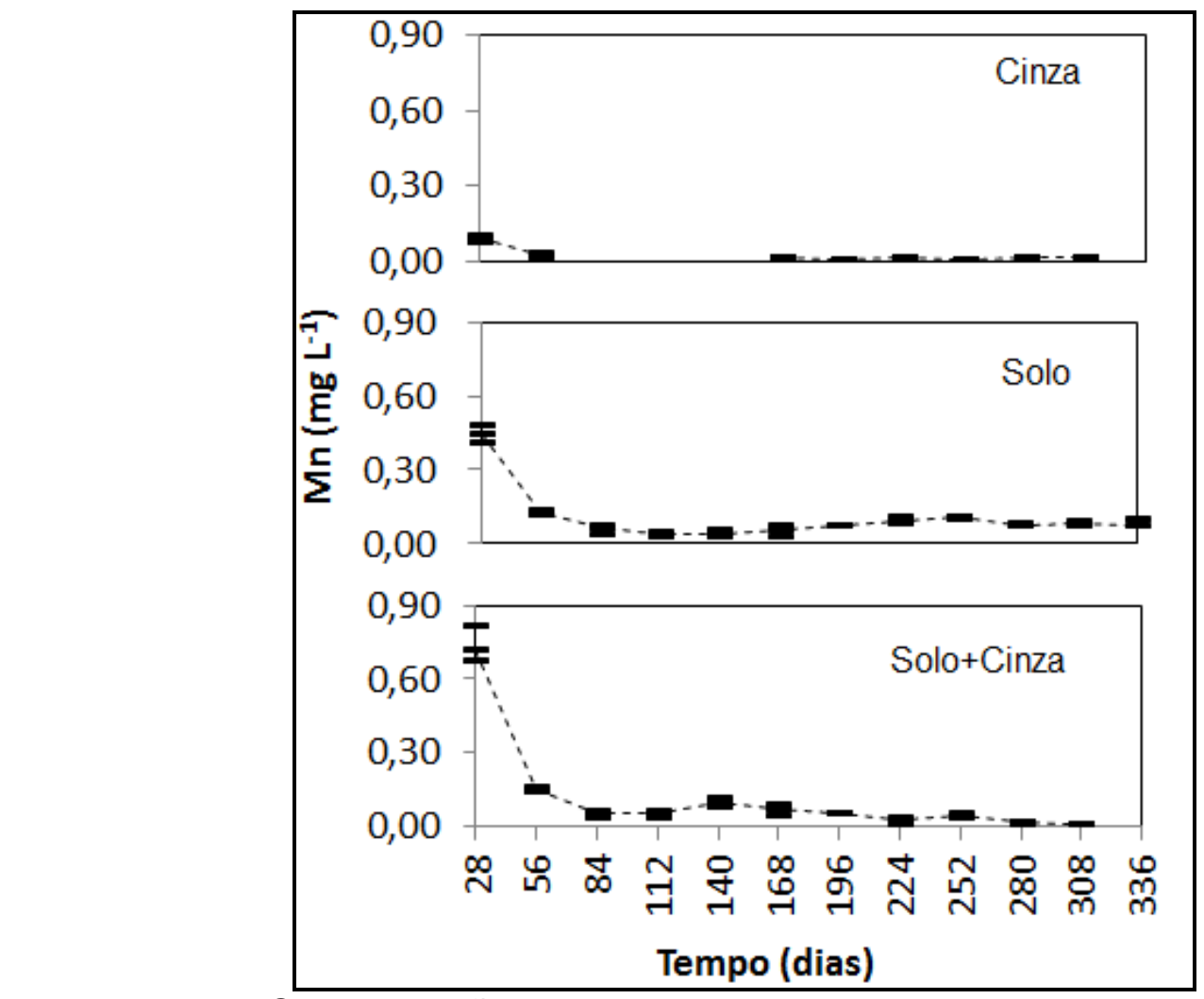

FIGURA 32 - Concentração de Mn dos percolados das colunas lixiviadas ao longo de 336 dias 
O manganês foi detectado em todos os percolados das colunas. Os resultados indicaram que grande parte do manganês encontrado nos percolados gerados não é proveniente da cinza de carvão, mas do próprio solo, conforme exposto na FIG.32.

ALLOWAY (1990) descreveu que Mn pode estar em diversas formas no solo, mas ressalta que não é adequado considerar a disponibilidade do $\mathrm{Mn}^{2+}$ somente considerando o $\mathrm{pH}$ como variável isolada, já que a disponibilidade de elétrons no meio também é um fator determinante. SPOSITO (1990) relatou que em solos ácidos as formas mais comuns de manganês na solução do solo são $\mathrm{Mn}^{2+}, \mathrm{MnSO}_{4}{ }^{0}$ e ligado a complexos orgânicos. MCBRIDE (1990) relatou que em meio ácido e redutor o $\mathrm{MnOOH}$ e $\mathrm{MnO}_{2}$ seriam solubilizados facilmente para $\mathrm{Mn}^{2+}$, porém essa reação seria dificultada em meio oxidante.

\subsubsection{Concentração dos ânions nos percolados}

Foram determinadas as concentrações dos ânions $\mathrm{SO}_{4}{ }^{2-}, \mathrm{NO}_{3}{ }^{-}, \mathrm{F}^{-}, \mathrm{Cl}^{-}$, $\mathrm{NO}_{2}{ }^{-}$e $\mathrm{PO}_{4}{ }^{3-}$ nos percolados das colunas. Esses ânions são comuns na solução do solo (YONG e MULLIGAN, 2004) e podem formar complexos iônicos solúveis ou compostos insolúveis com os elementos em estudo.

Os intervalos de concentrações dos ânions nos percolados das colunas foram apresentados na TAB.25.

TABELA 25 - Concentração dos ânions nos percolados das colunas Concentração dos ânions no percolado ( $\left.\mathrm{mg} \mathrm{L}^{-1}\right)$

\begin{tabular}{ccccc}
\hline Coluna & \multicolumn{4}{c}{ Concentração dos ânions no percolado $\left(\mathbf{m g ~ L}^{-1}\right)$} \\
& $\mathbf{F}$ & $\mathbf{C l}$ & $\mathbf{N O}_{3}{ }^{-}$ & $\mathbf{S O}_{4}{ }^{{ }^{-}}$ \\
\hline Solo & $0,25-0,02$ & $1,42-0,07$ & $59,93-0,16$ & $3,92-0,67$ \\
Solo + Cinza & $0,42-0,02$ & $1,88-0,07$ & $85,93-0,01$ & $603,49-0,94$ \\
Cinza & $2,06-0,15$ & $1,68-0,11$ & $79,57-0,10$ & $671,76-6,13$ \\
\hline
\end{tabular}

Fosfato e $\mathrm{NO}_{2}^{-}$não foram detectados acima dos limites de quantificação do método de cromatografia de íons. Para todos os ânions quantificados os maiores valores de concentração foram obtidos no primeiro tempo de lixiviação. De maneira geral, a concentração dos ânions foi diminuindo 
ao longo do período de lixiviação, sendo assim, esse fato é coerente com o comportamento da condutividade elétrica no percolado das colunas (FIG.28).

Foi observada uma concentração elevada de sulfato em relação aos demais ânions nos percolados das colunas da cinza de carvão. A seguinte ordem decrescente da concentração dos ânions foi obtida para as colunas de solo+cinza: $\mathrm{SO}_{4}{ }^{2-}>>\mathrm{NO}_{3}{ }^{-}>>\mathrm{Cl}^{-}>\mathrm{F}^{-}$. IZQUIERDO e QUEROL (2012) reuniram dados de diversos autores sobre o comportamento da lixiviação de elementos de cinzas de carvão e verificaram que sulfato e cálcio são os elementos encontrados majoritariamente nos percolados gerados por diversos tipos de soluções de lixiviação, tais como, água ou ácido acético.

Conforme resultados dos percolados das colunas (TAB.25), a cinza de carvão é responsável por liberação de nitrato e principalmente de sulfato, que pode ter contribuído fortemente para elevação do $\mathrm{pH}$ dos percolados das colunas de solo+cinza (FIG.26) pela sorção química desses ânions aos minerais do solo e consequentemente liberação de $\mathrm{OH}^{-}$, conforme discutido no item 5.3.1.1.

De acordo com SELIM e SPARKS (2001), que estudaram o mecanismo de adsorção de sulfato na goethita $(\mathrm{FeOOH})$, hematita $\left(\mathrm{Fe}_{2} \mathrm{O}_{3}\right)$ e ferrihidrita $\left(\mathrm{Fe}_{5}\left(\mathrm{O}_{4} \mathrm{H}_{3}\right)_{3}\right)$ em função do pH, força iônica e concentração de sulfato em solução, o mecanismo de sorção do sulfato por esses minerais é semelhante entre eles, mas pode variar dependendo do mineral em questão conforme exemplificado na FIG.33. 


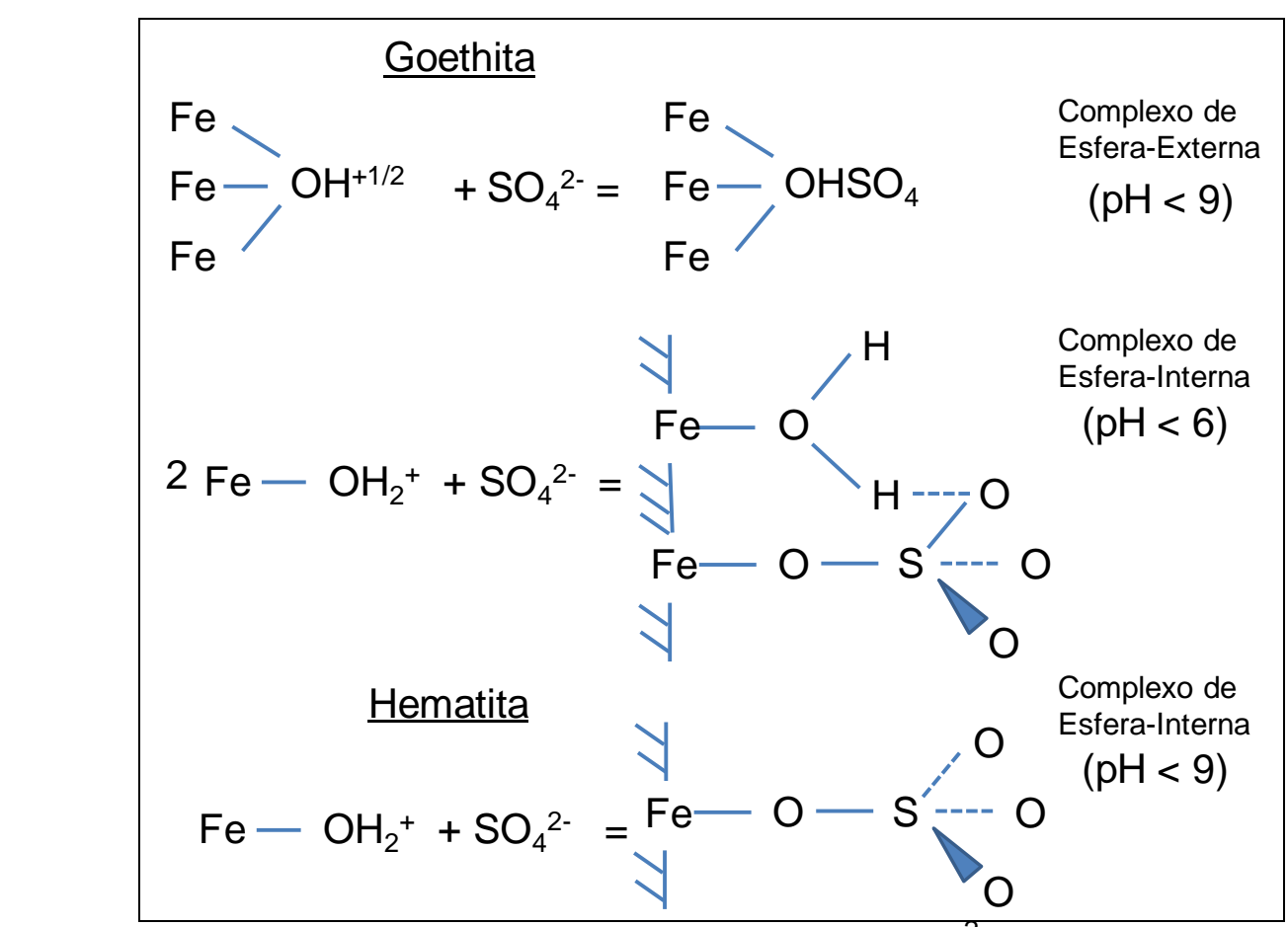

FIGURA 33 - Mecanismos de complexação de $\mathrm{SO}_{4}{ }^{2-}$ na goethita e hematita

(Fonte: SELIM e SPARKS, 2001)

A formação desses complexos de ferro-sulfato pode aumentar a concentração de ferro solúvel na solução do solo. HE et al. (1996) que estudaram a sorção de sulfato em gibbsita $\left(\mathrm{Al}(\mathrm{OH})_{3}\right)$, relataram que a formação de complexos de alumínio-sulfato em meio ácido facilitou a dissolução da gibbsita, resultando em maiores concentrações de alumínio na solução do solo. Entretanto, os resultados apresentados na FIG.25 indicaram que não foi observada redução significativa de óxidos de Al e Fe no solo após lixiviação.

\subsubsection{Concentração dos elementos majoritários nos percolados}

Foram determinadas as concentrações dos elementos majoritários $\mathrm{Na}$, $\mathrm{Mg}, \mathrm{Si}, \mathrm{K}$ e $\mathrm{Ca}$ nos percolados das colunas. Esses elementos são comumente presentes na solução do solo (YONG e MULLIGAN, 2004), podendo participar de reações de troca iônica nos colóides do solo competindo com os elementos em estudo.

Os intervalos de concentrações desses elementos nos percolados das colunas foram apresentados na TAB.26. 
TABELA 26 - Concentração dos elementos majoritários nos percolados das colunas

\begin{tabular}{lccccc}
\hline Coluna & \multicolumn{5}{c}{ Concentração dos elementos majoritários no percolado $\left(\mathbf{m g ~ L}^{-1}\right)$} \\
& $\mathbf{N a}$ & $\mathbf{M g}$ & $\mathbf{S i}$ & $\mathbf{K}$ & $\mathbf{C a}$ \\
\hline Solo & $1,04-0,09$ & $1,22-0,07$ & $6,28-0,65$ & $5,44-0,08$ & $2,20-0,18$ \\
Solo + Cinza & $44,80-0,18$ & $11,90-0,02$ & $8,04-2,30$ & $22,10-0,10$ & $163,00-1,96$ \\
Cinza & $55,60-0,28$ & $11,50-0,11$ & $7,87-3,45$ & $21,90-0,10$ & $251,00-4,57$ \\
\hline
\end{tabular}

Para todos os elementos majoritários quantificados os maiores valores de concentração também foram obtidos no primeiro tempo de lixiviação. De maneira geral, a concentração dos elementos majoritários foi diminuindo ao longo do período de lixiviação, sendo assim, esse fato é coerente com o comportamento da condutividade elétrica no percolado das colunas (FIG.28). Foi observado que as concentrações destes elementos obtidas nos percolados das colunas de solo foram inferiores àquelas obtidas para as colunas de cinza e solo+cinza. A seguinte ordem decrescente da concentração dos elementos majoritários foi obtida para as colunas de solo+cinza: $\mathrm{Ca}>>\mathrm{Na}>\mathrm{K}>\mathrm{Mg}>\mathrm{Si}$.

Conforme citado no item 5.3.3, IZQUIERDO e QUEROL (2012) verificaram que sulfato e cálcio são os elementos encontrados majoritariamente nos percolados das cinzas de carvão, descrevendo que a razão entre Ca e $S$ nas cinzas leves influencia no $\mathrm{pH}$ da cinza e que as cinzas que apresentam uma razão $\mathrm{Ca} / \mathrm{S} \leq 1$ podem ser consideradas moderadamente alcalinas ou ainda moderadamente ácidas. Ainda de acordo com os mesmos autores, a solubilidade de determinados elementos tóxicos, tais como, As em extratores aquosos é muito maior em cinzas com razão $\mathrm{Ca} / \mathrm{S} \leq 1$ do que em cinzas com Ca/S $>>1$ (fortemente alcalinas). Tal informação pode ser interessante do ponto de vista da mobilidade dos elementos tóxicos em estudo, visto que, $\mathrm{O} \mathrm{pH}_{\mathrm{H} 2 \mathrm{O}}$ determinado na cinza em estudo foi 7,4 (TAB.19) e que a razão Ca/S encontrada foi $\leq 1$.

\subsection{Determinação das vazões e coeficiente de permeabilidade das colunas}

A vazão de saída dos percolados das colunas de solo, solo+cinza e cinza ao longo do período de lixiviação foi calculada com a finalidade de se avaliar 
uma possível alteração na vazão. Esse parâmetro foi determinado mensalmente para cada coluna e as médias mensais foram comparadas com o volume dos percolados das colunas ao longo do tempo (FIG.34).

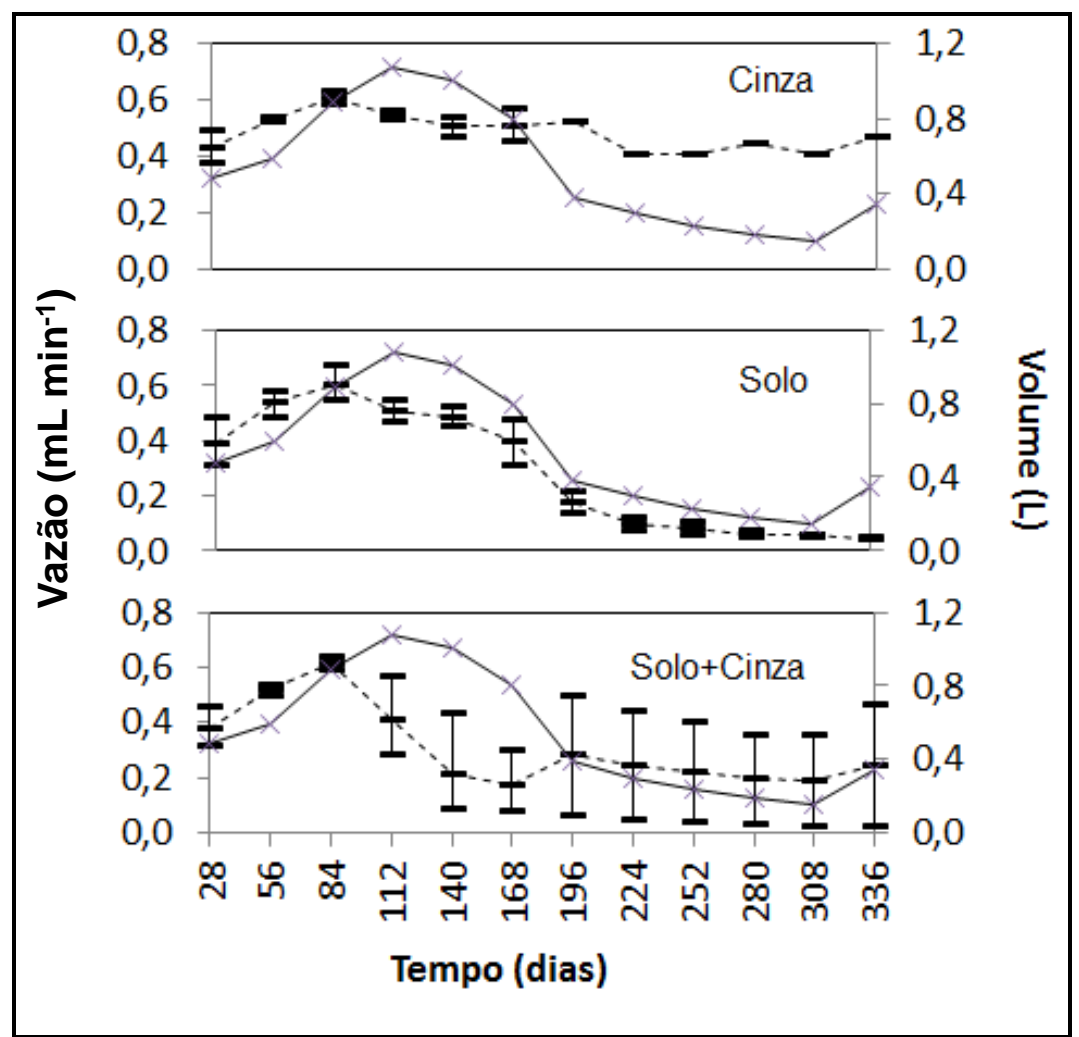

FIGURA 34 - Vazão de saída da coluna (---) e volume (-) dos percolados das colunas lixiviadas ao longo de 336 dias

Na FIG.34 foi observado que a vazão das colunas de cinza não variou ao longo do tempo, porém a vazão das colunas de solo diminuiu ao longo do tempo seguindo o mesmo comportamento da curva de volume. A vazão das colunas de solo+cinza também diminuiu ao longo tempo, porém as réplicas desse tipo de coluna não apresentaram boa reprodutibilidade a partir dos 112 dias de lixiviação das colunas, principalmente nos últimos seis tempo de lixiviação, provavelmente devido a eventos de entupimento das mesmas ao longo da lixiviação.

O coeficiente de permeabilidade das colunas de solo, solo+cinza e cinza ao longo do período de lixiviação foi calculado com base na equação 9 (item 4.5), utilizando a vazão das colunas (FIG.34). Esse parâmetro foi determinado mensalmente para cada coluna conforme exposto na FIG.35. 


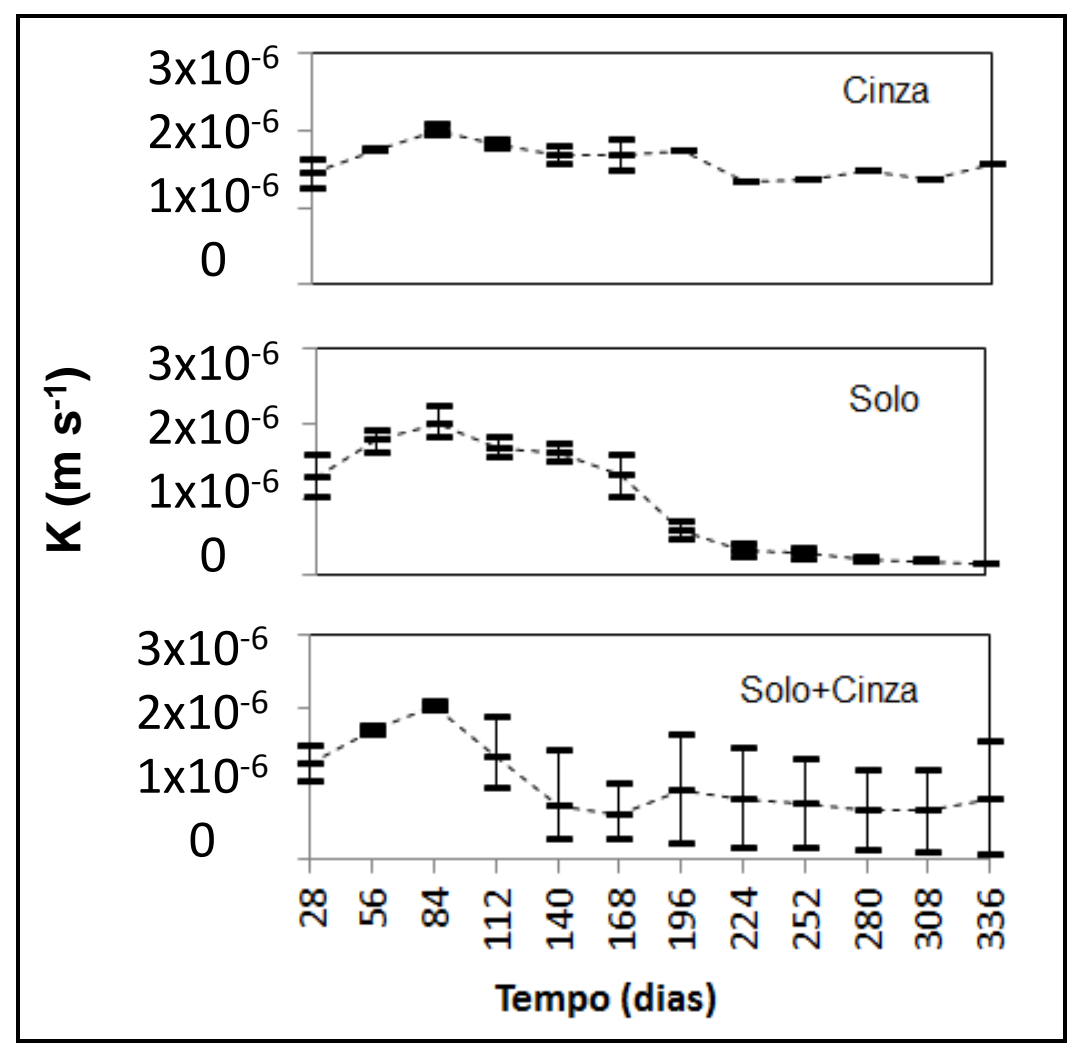

FIGURA 35 - Coeficiente de permeabilidade das colunas lixiviadas ao longo de 336 dias

$\mathrm{Na}$ FIG.35 foi observado que o coeficiente de permeabilidade das colunas de cinza não variou ao longo do tempo, porém o coeficiente das colunas de solo e solo+cinza diminuiu ao longo tempo, como já tinha sido observado para a vazão das colunas (FIG.34). Embora tenha sido observada uma diminuição do coeficiente de permeabilidade ao longo do tempo para as colunas de solo e solo+cinza, a ordem de grandeza do coeficiente de permeabilidade foi a mesma para todas as colunas (cinza, solo e solo+cinza). Considerando a razão entre a média do coeficiente de permeabilidade para os primeiros 168 dias e a média do coeficiente para os últimos 168 dias de lixiviação, a razão para a coluna de cinza é aproximadamente igual a 1,2, ao passo que para as colunas de solo a razão foi de aproximadamente 5,8 e para a coluna de solo+cinza a razão foi de 1,7 . Isso indicou que a diminuição do coeficiente de permeabilidade do solo ao longo do tempo de lixiviação está relacionado com o próprio solo e não com a cinza de carvão. 


\subsection{Determinação dos elementos tóxicos}

Os elementos tóxicos As, Mo, Cd, Zn e Pb foram determinados nos diferentes compartimentos do sistema de lixiviação das colunas, ou seja, na cinza de carvão, no solo e no percolado das colunas. Os resultados obtidos foram apresentados nos subitens a seguir.

\subsubsection{Concentração dos elementos no percolado das colunas}

A concentração de As, Cd, Mo, Zn e Pb nos percolados das colunas foi determinada ao longo de 336 dias com o objetivo de se avaliar a lixiviação dos elementos tóxicos das colunas de cinza, solo e solo+cinza.

\subsubsection{Chumbo}

Os resultados mostraram que o chumbo, apesar de presente na cinza de carvão (TAB.18), não foi lixiviado quando submetido às condições do experimento, uma vez que, ao longo dos 336 dias de lixiviação não foram detectados valores acima do limite de quantificação do AAS-GF $\left(<0,001 \mathrm{mg} \mathrm{L}^{-1}\right)$ para este elemento nos percolados das colunas de cinza.

Numa revisão sobre o comportamento da lixiviação de elementos tóxicos da cinza de carvão, IZQUIERDO e QUEROL (2012) mencionaram a existência de diversos estudos de lixiviação de cinza de carvão, nos quais o $\mathrm{Pb}$ não foi lixiviado.

DUTTA et al. (2009) mencionaram que o $\mathrm{Pb}$ encontrou-se associado à fase vítrea da cinza de carvão e tal fato dificultaria a dissolução desse elemento. Os mesmos autores ressaltaram ainda que as altas concentrações de $\mathrm{SO}_{4}{ }^{2-}$ poderiam promover a precipitação de $\mathrm{PbSO}_{4}$, inibindo a lixiviação do $\mathrm{Pb}$.

DEPOI et al. (2008) realizaram um experimento no qual misturaram água deionizada com cinza de carvão para simular a lixiviação de elementos das cinzas de carvão do Brasil e verificaram uma lixiviação de apenas 0,02\% de Pb na cinza de carvão da usina termelétrica de Figueira. 


\subsubsection{Arsênio}

As médias das concentrações de arsênio nos percolados das colunas de cinza e solo+cinza ao longo de 336 dias foram ilustradas na FIG.36. Este mesmo elemento não foi detectado no percolado das colunas de solo, pois os valores de concentração foram abaixo do limite de quantificação do método.

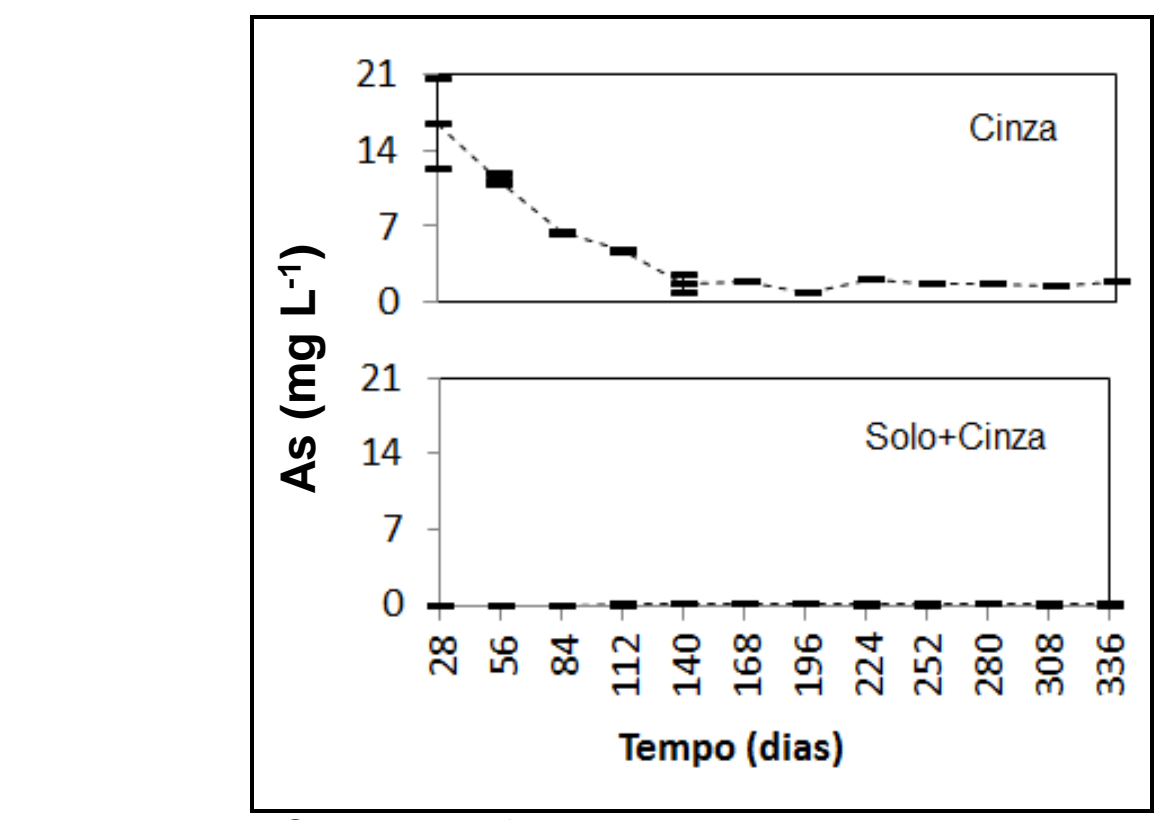

FIGURA 36 - Concentração de As nos percolados das colunas de cinza e solo+cinza ao longo de 336 dias

Os resultados da FIG.36 indicaram que a concentração de arsênio encontrada nos percolados das colunas de solo com cinza foi bem inferior daquela encontrada nos percolados das colunas de cinza, ou seja, isto indicou que boa parte do As ficou retida no solo.

A concentração de As no percolado das colunas de cinza (FIG.36) apresentou um declínio gradual até 140 dias de lixiviação e a partir deste tempo essa concentração apresentou-se praticamente constante. No percolado das colunas de solo+cinza a concentração de As foi menor nos primeiros 84 dias de lixiviação quando comparada com a concentração observada a partir dos 112 dias quando essa concentração aumentou atingindo um valor máximo em 140 dias, seguida de queda gradual nos dias restantes. Esse comportamento foi similar ao observado por QUEROL et al. (2001), no qual foi apresentada a concentração de 
As lixiviado da cinza pelo volume do lixiviado. Uma das cinzas de carvão estudadas pelos autores foi moderadamente alcalina e o experimento foi realizado em ensaio de coluna utilizando água deionizada como solução simuladora de chuva. O resultado encontrado no presente estudo (FIG.37-B) apresentou um comportamento similar àquele observado pelos autores (FIG.37-A), ou seja, queda gradual da concentração de As nos primeiros volumes do lixiviado seguida de estabilização da concentração nos últimos volumes do lixiviado.

O comportamento da lixiviação de elementos tóxicos da cinza de carvão foi estudado em trabalhos recentes (IZQUIERDO e QUEROL, 2012; KASHIWAKURA et al., 2010; DUTTA et al., 2009; DEPOI et al., 2008; JEGADEESAN et al., 2008; WANG et al., 2008; QUEROL et al., 2001), nos quais foram destacados fatores como tempo de lixiviação, $\mathrm{pH}$ da solução, $\mathrm{pH}$ da cinza, espécie química dos elementos na cinza, proporção líquido:sólido e quantidade de $\mathrm{Ca}$ e $\mathrm{SO}_{4}{ }^{2-}$ presente na cinza, como os principais fatores no controle da lixiviação dos elementos da cinza de carvão.

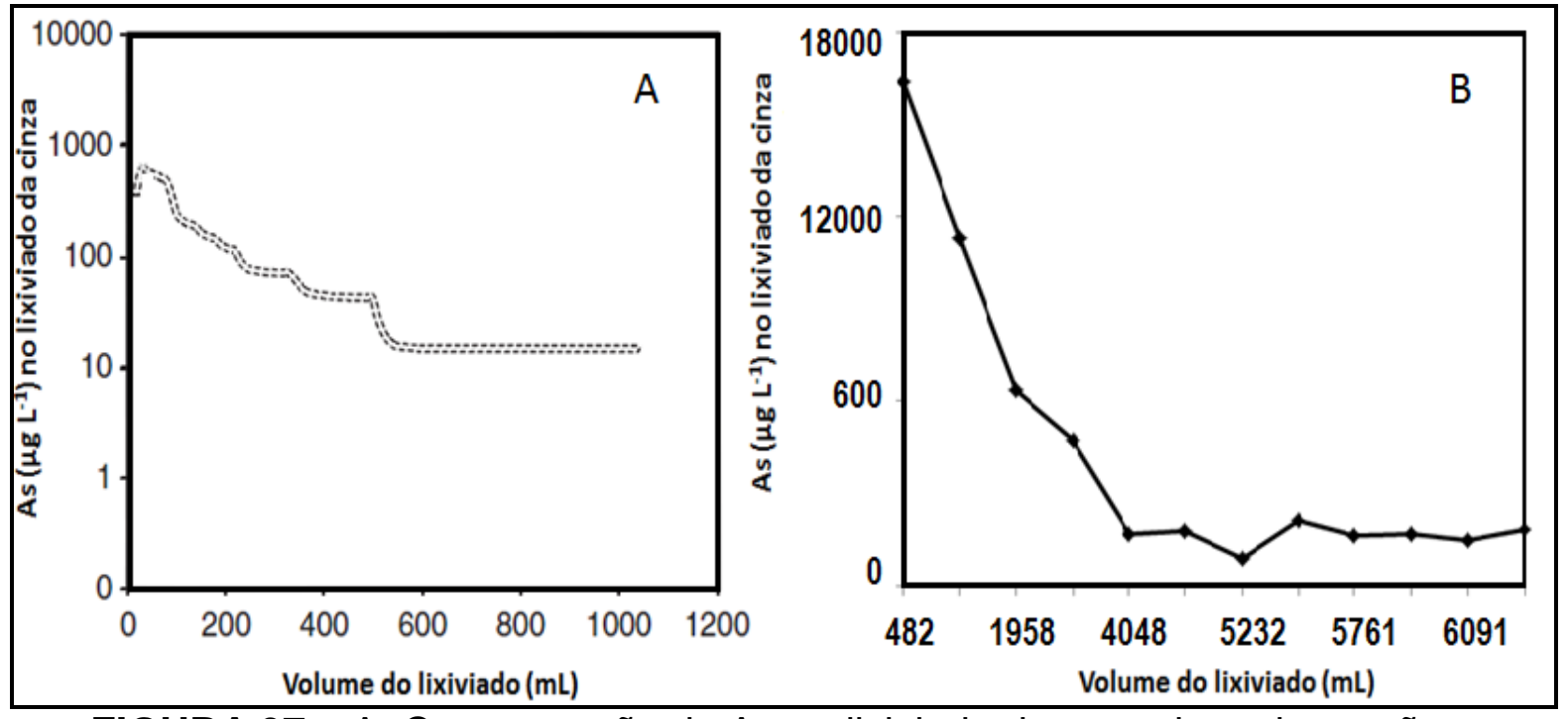

FIGURA 37 - A: Concentração de As no lixiviado de uma cinza de carvão moderadamente alcalina obtida por QUEROL et al. (2001). B: Concentração de As no lixiviado da cinza de carvão obtida no presente estudo

Os trabalhos supracitados também descrevem que o arsênio é considerado um elemento preocupante do ponto de vista ambiental, pois pode ser lixiviado da cinza de carvão numa ampla faixa de $\mathrm{pH}$, sendo que, em condições 
mais drásticas $(\mathrm{pH}<4$ e $\mathrm{pH}>9)$ sua solubilidade seria ainda mais favorecida. Tal comportamento se deve ao fato desse elemento estar associado principalmente à superfície das partículas da cinza de carvão.

\subsubsection{Molibdênio}

As médias das concentrações de molibdênio nos percolados das colunas de cinza ao longo de 336 dias foram ilustradas na FIG.38. Este mesmo elemento não foi detectado no percolado das colunas de solo e solo+cinza, pois os valores de concentração foram abaixo do limite de quantificação do método.

FIGURA 38 - Concentração de Mo nos percolados das colunas de cinza ao longo de 336 dias

Observou-se que uma maior quantidade de Mo foi liberada da cinza nos primeiros 28 dias de lixiviação e esta quantidade diminuiu acentuadamente a partir dos 56 dias. Assim como para o As, o Mo encontra-se essencialmente associado na superfície da cinza de carvão (QUEROL et al., 2001) e por isso é facilmente lixiviado.

No mesmo estudo de QUEROL et al. (2001) citado no item 5.5.1.2 para a lixiviação do arsênio, a concentração de Mo lixiviada da cinza pelo volume do lixiviado também foi ilustrada. Tal resultado foi comparado com o resultado obtido no presente estudo (FIG.39), no qual é possível observar similaridade no comportamento de lixiviação do elemento, ou seja, queda gradual da 
concentração de Mo nos primeiros volumes do lixiviado seguida de estabilização da concentração nos últimos volumes do lixiviado.

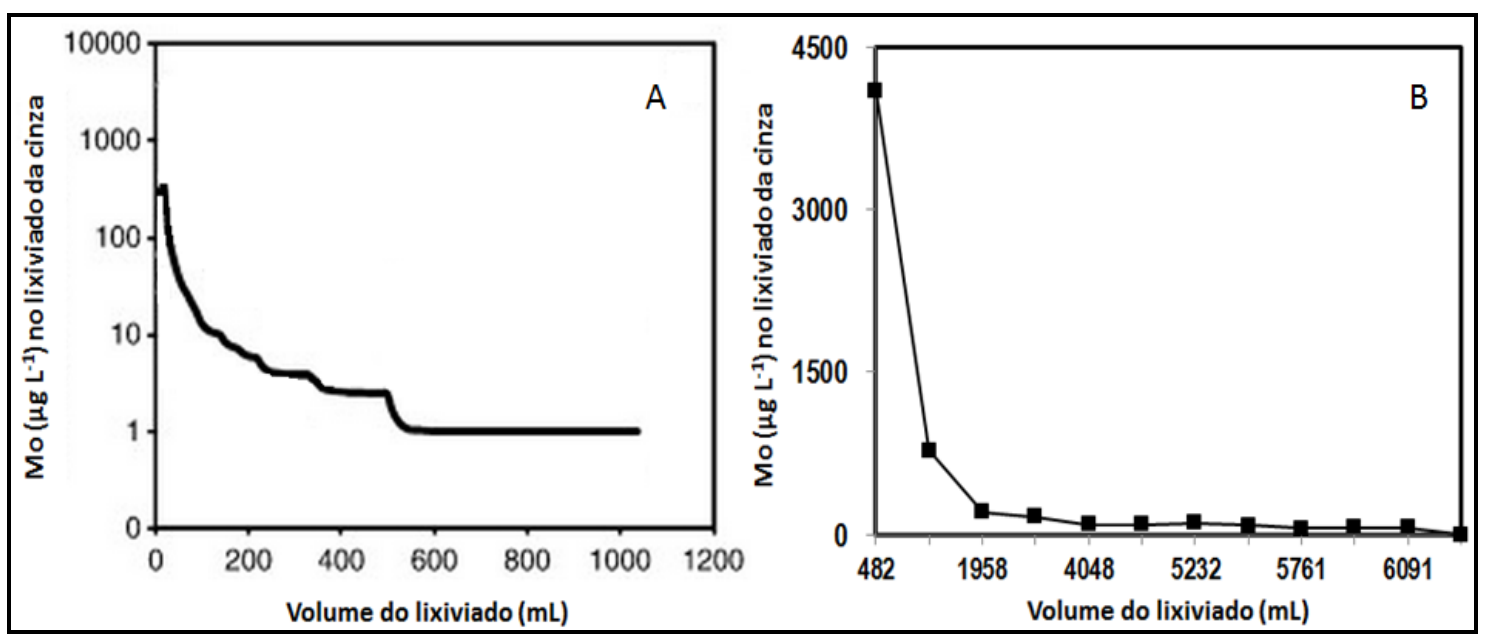

FIGURA 39 - A: Concentração de Mo no lixiviado de uma cinza de carvão moderadamente alcalina obtida por QUEROL et al. (2001). B: Concentração de Mo no lixiviado da cinza de carvão obtida no presente estudo

O fato do molibdênio não ter sido detectado no percolado das colunas de solo+cinza indicou que esse elemento ficou retido no solo.

\subsubsection{Cádmio}

As médias das concentrações de cádmio nos percolados das colunas de cinza ao longo de 336 dias foram ilustradas na FIG.40. Este mesmo elemento não foi detectado no percolado das colunas de solo e solo+cinza, pois os valores de concentração foram abaixo do limite de quantificação do método.

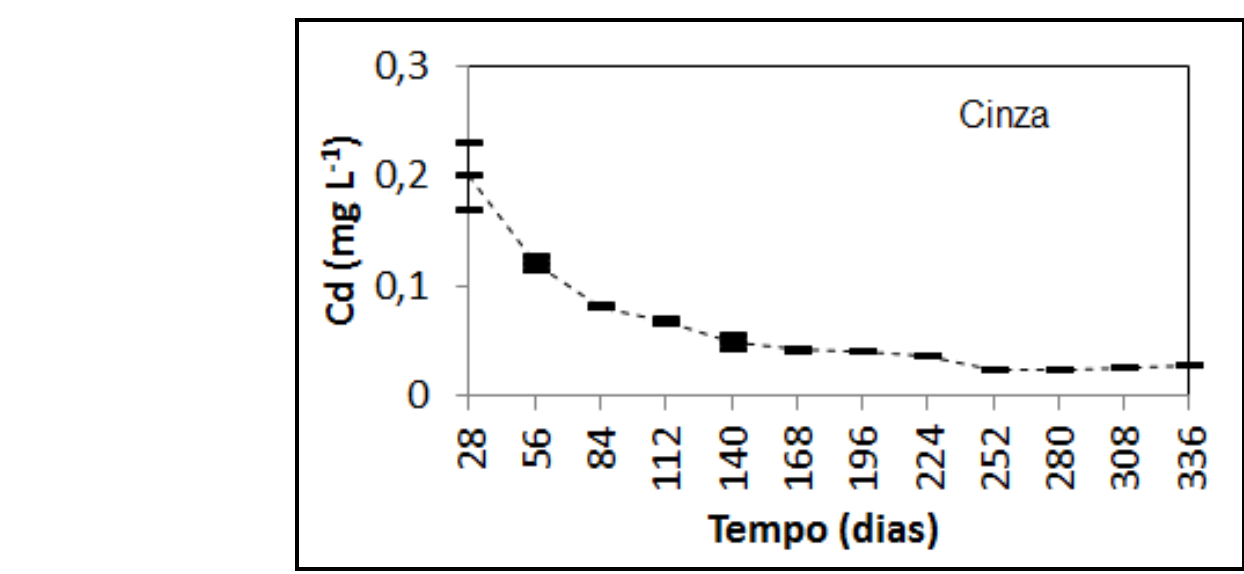

FIGURA 40 - Concentração de Cd nos percolados das colunas de cinza ao longo de 336 dias 
Observou-se que uma maior quantidade de $\mathrm{Cd}$ foi liberada da cinza nos primeiros dias de lixiviação e diminuiu de modo mais gradual quando comparado com a lixiviação de Mo (FIG.38) e se assemelhou com o comportamento do As (FIG.36).

ALLOWAY (1990) relatou que esse elemento tende a formar complexos com cloretos e grupos hidroxilas podendo mobilizar o elemento.

O fato do cádmio não ter sido detectado no percolado das colunas de solo+cinza indicou que esse elemento ficou retido no solo.

\subsubsection{Zinco}

As médias das concentrações de zinco nos percolados das colunas ao longo de 336 dias foram ilustradas na FIG.41.

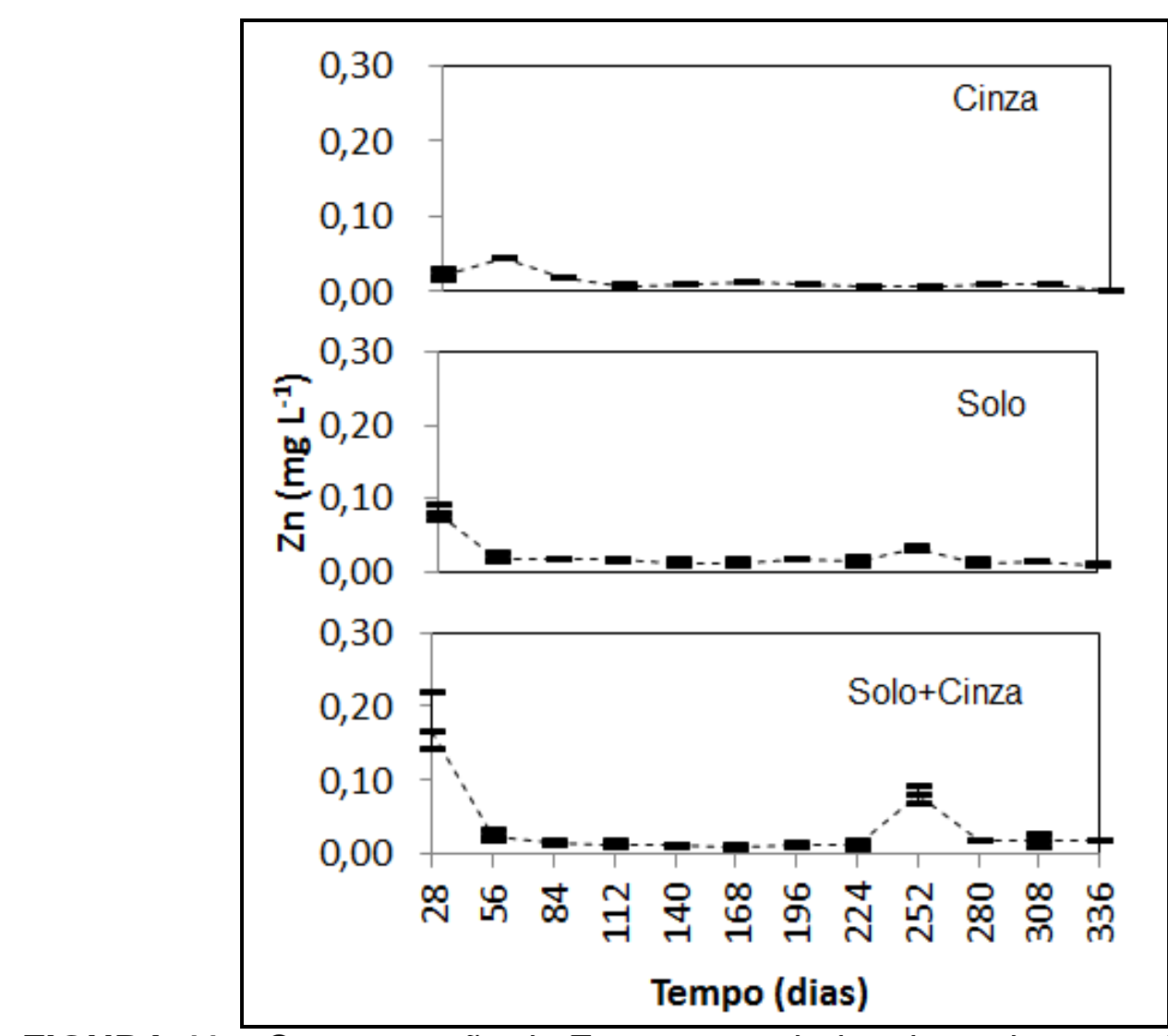

FIGURA 41 - Concentração de Zn nos percolados das colunas ao longo de 336 dias 
O Zn foi detectado nos percolados das colunas de solo (FIG.41), apesar de não ter sido detectado no solo por fluorescência de raios-X (TAB.21). Isso indicou a presença desse elemento no solo. Observou-se que as concentrações de $\mathrm{Zn}$ no percolado das colunas de cinza e solo são da mesma ordem de grandeza, porém a concentração de $\mathrm{Zn}$ detectada nos percolados das colunas de solo+cinza foi mais elevada, indicando que a cinza influencia na liberação de Zn do próprio solo.

JEGADEESAN et al. (2008) destacaram que o zinco presente na cinza de carvão não representou preocupação ambiental, pois sua distribuição na cinza estaria associada principalmente nas frações silicatadas pouco solúveis.

Foi observado nos resultados de Zn (FIG.41) e nos apresentados anteriormente para As, Mo e Cd (FIG.36, FIG.38 e FIG.40, respectivamente), uma maior concentração dos elementos nos percolados das colunas nos primeiros dias de lixiviação, exceto para o arsênio nas colunas de solo+cinza. Esses resultados estão de acordo com o comportamento da condutividade elétrica medida nos percolados das colunas (FIG.28).

\subsubsection{Massa dos elementos no percolado das colunas ( $\mathrm{mp}$ )}

Para obter os resultados em massa $(\mathrm{mg})$ do elemento lixiviado ao longo de 336 dias em cada coluna, as concentrações dos elementos obtidas em $\mathrm{mg} \mathrm{L}^{-1}$ no percolado das colunas coletado a cada 28 dias (item 5.5.1) foram multiplicadas pelos respectivos volumes (L). A massa total dos elementos no percolado das colunas lixiviadas em 336 dias foi calculada pela somatória das massas dos elementos nos percolados calculadas a cada 28 dias para cada coluna, com base na equação 17 .

A massa total dos elementos no percolado das colunas de cinza, solo e solo+cinza foi ilustrada na TAB.27. 
TABELA 27 - Massa total dos elementos no percolado das colunas

\begin{tabular}{|c|c|c|c|c|c|c|c|c|c|c|c|c|}
\hline \multirow{3}{*}{$\begin{array}{c}\text { Percolado } \\
\text { das } \\
\text { colunas }\end{array}$} & \multicolumn{3}{|c|}{ As (mg) } & \multicolumn{3}{|c|}{ Mo (mg) } & \multicolumn{3}{|c|}{$\mathrm{Zn}(\mathrm{mg})$} & \multicolumn{3}{|c|}{$\mathrm{Cd}(\mathrm{mg})$} \\
\hline & \multirow{2}{*}{ Média } & \multicolumn{2}{|c|}{ Intervalo } & \multirow{2}{*}{ Média } & \multicolumn{2}{|c|}{ Intervalo } & \multirow{2}{*}{ Média } & \multicolumn{2}{|c|}{ Intervalo } & \multirow{2}{*}{ Média } & \multicolumn{2}{|c|}{ Intervalo } \\
\hline & & Máx & Mín & & Máx & Mín & & Máx & Mín & & Máx & Mín \\
\hline Cinza & $\begin{array}{c}30,1 \\
(n=2)\end{array}$ & 32,2 & 25,6 & $\begin{array}{c}2,9 \\
(n=2)\end{array}$ & 2,9 & 2,8 & $\begin{array}{l}0,08 \\
(n=2)\end{array}$ & 0,08 & 0,07 & 0,43 & 0,45 & 0,41 \\
\hline Solo & $\begin{array}{l}<L Q \\
(n=4)\end{array}$ & - & - & $\begin{array}{l}<L Q \\
(n=4)\end{array}$ & - & - & $\begin{array}{l}0,14 \\
(n=4)\end{array}$ & 0,15 & 0,13 & $\begin{array}{l}<L Q \\
(n=4)\end{array}$ & - & - \\
\hline Solo+cinza & $\begin{array}{l}0,56 \\
(n=4)\end{array}$ & 0,67 & 0,19 & $\begin{array}{l}<\mathrm{LQ} \\
(\mathrm{n}=4)\end{array}$ & - & - & $\begin{array}{l}0,17 \\
(n=4)\end{array}$ & 0,20 & 0,15 & $\begin{array}{l}<\mathrm{LQ} \\
(\mathrm{n}=4)\end{array}$ & - & - \\
\hline
\end{tabular}

$\mathrm{n}=$ número de amostras e $\mathrm{LQ}=$ limite de quantificação do método

\subsubsection{Comparação entre a concentração dos elementos nos percolados das} colunas e o valor de referência ambiental

A concentração dos elementos no percolado das colunas obtida ao longo de 336 dias de lixiviação e o valor de intervenção para água subterrânea estabelecido pela CETESB (2005) foram apresentados na TAB.28.

TABELA 28 - Concentração dos elementos no percolado das colunas e valor de intervenção para água subterrânea do Estado de São Paulo (CETESB, 2005)

\begin{tabular}{cccc}
\hline Elemento & \multicolumn{2}{c}{ Concentração dos elementos no percolado $\left(\mathbf{m g ~ L}^{-1}\right)$} & $\begin{array}{c}\text { Valor de } \\
\text { Intervencão } \\
\left(\mathbf{m g ~ L}^{-1}\right)\end{array}$ \\
\hline As & Colunas de Cinza & Colunas de Solo+Cinza & 0,010 \\
Cd & $0,796-20,500$ & $0,002-0,246$ & 0,005 \\
Zn & $0,023-0,230$ & nd & 5,000 \\
Mo & $0,006-0,044$ & $0,005-0,219$ & 0,070 \\
\hline
\end{tabular}

nd: não detectado acima do limite de quantificação do método

Como descrito anteriormente os elementos $\mathrm{Cd}$ e Mo não foram detectados nos percolados das colunas de solo+cinza.

A comparação da concentração dos elementos no percolado das colunas de solo+cinza com os valores de intervenção para água subterrânea não pode ser direta, pois, os elementos podem sofrer interações com as diversas camadas do solo ao longo do seu perfil. A CETESB (2005) adotou um fator igual a 10 para considerar a atenuação natural do elemento na solução do solo até a água subterrânea. Dividindo-se os valores de As e Zn apresentados na TAB.28 por 10, pôde-se verificar que apenas a concentração de As determinada no 
percolado das colunas de solo+cinza ultrapassaria os valores de intervenção para água subterrânea estabelecido pela CETESB (2005).

Do ponto de vista toxicológico, As apresenta toxicidade moderada e alta para plantas e mamíferos ao passo que $\mathrm{Zn}$ apresenta toxicidade baixa e moderada (MCBRIDE, 1994). Dentre os elementos determinados no percolado das colunas de solo+cinza o As pode ser considerado o mais crítico do ponto de vista ambiental e de saúde pública. O risco ambiental envolvido na disposição inadequada da cinza vai depender de alguns fatores, tais como, quantidade da cinza disposta no solo, características físicas e químicas do solo, quantidade de chuva e tempo de exposição dos receptores a esses elementos tóxicos.

\subsubsection{Concentração dos elementos na cinza de carvão}

A concentração de $\mathrm{As}, \mathrm{Cd}, \mathrm{Mo}, \mathrm{Zn}$ e $\mathrm{Pb}$ na cinza de carvão obtida antes e depois da lixiviação por digestão ácida, conforme descrito no item 4.8.2.2.1, foi apresentada na TAB.29 com o objetivo de se avaliar os elementos que foram lixiviados da cinza de carvão. Esta concentração representa a concentração potencialmente disponível para o meio e não a concentração total dos elementos na amostra de cinza de carvão. 
TABELA 29 - Concentração parcial dos elementos nos extratos de cinza de carvão obtidos por digestão ácida

\begin{tabular}{|c|c|c|c|c|c|c|c|c|c|c|c|c|c|}
\hline \multirow[t]{3}{*}{ Elemento } & \multirow[t]{3}{*}{$\begin{array}{c}\text { Tempo } \\
\text { (dias) }\end{array}$} & \multicolumn{4}{|c|}{$\begin{array}{c}\text { Cinza } \\
\text { não lixiviada }\end{array}$} & \multicolumn{8}{|c|}{ Cinza Lixiviada } \\
\hline & & \multirow{2}{*}{$\underset{\left(\mathrm{mg} \mathrm{kg}^{-1}\right)}{\text { média }}$} & \multirow{2}{*}{$\begin{array}{l}\mathbf{s r} \\
(\%)\end{array}$} & \multicolumn{2}{|c|}{$\begin{array}{l}\text { Intervalo } \\
\left(\mathbf{m g ~ k g}^{-1}\right)\end{array}$} & \multirow{2}{*}{$\underset{\left(\mathrm{mg} \mathrm{kg}^{-1}\right)}{\text { média }}$} & \multirow{2}{*}{$\begin{array}{l}\mathbf{s r} \\
(\%)\end{array}$} & \multicolumn{2}{|c|}{$\begin{array}{l}\text { Intervalo } \\
\left(\mathrm{mg} \mathrm{kg}^{-1}\right)\end{array}$} & \multirow{2}{*}{$\begin{array}{c}\text { média } \\
\left(\mathrm{mg} \mathrm{kg}^{-1}\right)\end{array}$} & \multirow{2}{*}{$\begin{array}{l}\mathbf{s r} \\
(\%)\end{array}$} & \multicolumn{2}{|c|}{$\begin{array}{c}\text { Intervalo } \\
\left(\mathrm{mg} \mathrm{kg}^{-1}\right)\end{array}$} \\
\hline & & & & Máx & Mín & & & Máx & Mín & & & Máx & Mín \\
\hline \multirow{3}{*}{$\mathrm{Zn}$} & 0 & $778(n=2)$ & 2,4 & 791 & 765 & - & - & - & - & - & - & - & - \\
\hline & 168 & - & - & - & - & $607(n=2)$ & 0,0 & - & - & $542(n=4)$ & 6,8 & 569 & 488 \\
\hline & 336 & - & - & - & - & $526(n=2)$ & 3,6 & 540 & 513 & $522(n=4)$ & 16,7 & 581 & 395 \\
\hline \multirow{3}{*}{ Mo } & 0 & $82(n=2)$ & 2,3 & 83 & 80 & - & - & - & - & - & - & - & - \\
\hline & 168 & - & - & - & - & $28,2(n=2)$ & 2,3 & 28,6 & 27,7 & $26,9(n=4)$ & 7,9 & 29,3 & 24,6 \\
\hline & 336 & - & - & - & - & $23,5(n=2)$ & 2,4 & 23,9 & 23,1 & $24,6(n=2)$ & 4,6 & 25,4 & 23,8 \\
\hline \multirow{3}{*}{ Cd } & 0 & $37,0(n=2)$ & 1,5 & 37,4 & 36,6 & - & - & - & - & - & - & - & - \\
\hline & 168 & - & - & - & - & $28,1(n=2)$ & 2,8 & 28,6 & 27,5 & $19,7(n=4)$ & 6,6 & 21,5 & 18,6 \\
\hline & 336 & - & - & - & - & $26,1(n=2)$ & 1,4 & 26,3 & 25,8 & $15,2(n=4)$ & 13,7 & 16,7 & 12,2 \\
\hline \multirow{3}{*}{ As } & 0 & $1635(\mathrm{n}=2)$ & 3,9 & 1680 & 1590 & - & - & - & - & - & - & - & - \\
\hline & 168 & - & - & - & - & $1095(n=2)$ & 1,9 & 1110 & 1080 & $1160(n=4)$ & 2,3 & 1200 & 1140 \\
\hline & 336 & - & - & - & - & $1025(n=2)$ & 2,1 & 1040 & 1010 & $1047(n=3)$ & 4,3 & 1090 & 1000 \\
\hline \multirow{3}{*}{$\mathrm{Pb}$} & 0 & $154(n=2)$ & 2,8 & 157 & 151 & - & - & - & - & - & - & - & - \\
\hline & 168 & - & - & - & - & $159(n=2)$ & 3,1 & 162 & 155 & $154(n=4)$ & 5,7 & 161 & 142 \\
\hline & 336 & - & - & - & - & $152(n=2)$ & 1,4 & 153 & 150 & $136(n=3)$ & 6,4 & 141 & 126 \\
\hline
\end{tabular}

$\mathrm{n}=$ número de amostras e sr= desvio padrão relativo

De maneira geral, o método para a determinação dos elementos na cinza de carvão ofereceu uma reprodutibilidade satisfatória com um desvio padrão relativo variando de 1,4 a $16,7 \%$ (TAB.29).

Os resultados encontrados nas amostras de cinza lixiviada (TAB.29) estão de acordo com aqueles encontrados para o $\mathrm{Pb}$ nos percolados das colunas (item 5.5.1.1). No percolado da cinza de carvão não foi detectada a presença de $\mathrm{Pb}$ acima do limite de quantificação do método e os valores de $\mathrm{Pb}$ na cinza lixiviada foram muito próximos dos valores da cinza não lixiviada (TAB.29).

Considerando os resultados apresentados para $\mathrm{Pb}$ no item 5.5.1.1 e na TAB.29 conclui-se que este elemento não foi lixiviado da cinza de carvão e portanto não representa risco de contaminação do solo. Sendo assim, esse elemento não foi determinado nas amostras de solo. Para os demais elementos 
tóxicos (As, $\mathrm{Cd}$, Mo e $\mathrm{Zn}$ ) foi observada uma diminuição na concentração dos mesmos na cinza após a lixiviação, ou seja, indicando que esses elementos foram lixiviados da cinza. Isso é coerente com os gráficos de concentração destes elementos no percolado das colunas de cinza (item 5.5.1).

Considerando a razão entre a média da concentração dos elementos obtidos nas amostras de cinza para os 168 dias de lixiviação e a média da concentração para os 336 dias, a menor razão obtida foi de aproximadamente 1,0 $(\mathrm{Zn})$, ao passo que a maior razão foi de aproximadamente 1,3 (Cd). Isso indicou que não foram observadas diferenças representativas entre os períodos de $168 \mathrm{e}$ 336 dias de lixiviação na maioria dos valores para a concentração dos elementos na cinza lixiviada (TAB.29), ou seja, os elementos são predominantemente lixiviados da cinza nos primeiros 168 dias de lixiviação. Isso está coerente com os gráficos de concentração dos elementos no percolado das colunas de cinza de carvão (FIG.36, 38, 40 e 41). Assim sendo, as médias dos valores da concentração dos elementos na cinza de carvão foram determinadas considerando os dois períodos de lixiviação, de 168 e 336 dias, nas discussões subsequentes.

A razão entre a média da concentração dos elementos na cinza lixiviada das colunas de cinza e solo+cinza (TAB.29) também considerada. A razão obtida para o $\mathrm{Cd}$ foi 1,6, ao passo que os demais elementos apresentaram razões igual a 1 aproximadamente. Desta maneira, os valores de concentração dos elementos na cinza de carvão lixiviada nas diferentes colunas (cinza e solo+cinza) foram considerados como resultados independentes nas discussões subsequentes.

Os elementos majoritários também foram determinados nas amostras de cinza de carvão por digestão ácida, porém esses dados não foram utilizados no presente estudo e foram apresentados na TAB.1A do APÊNDICE 1.

\subsubsection{Massa do elemento lixiviado da cinza de carvão $(\mathrm{mc})$}

Para obter os resultados em massa $(\mathrm{mg})$ do elemento presente na cinza de carvão lixiviada e não lixiviada, as concentrações dos elementos nos 
extratos de cinza obtidos por digestão ácida em $\mathrm{mg} \mathrm{kg}^{-1}$ (TAB.29) foram multiplicadas pela massa de cinza de carvão adicionada no topo das colunas $(0,05 \mathrm{~kg})$.

Na TAB.30 foi apresentada a massa de As, Mo, Zn e Cd obtida na cinza de carvão após 336 dias de lixiviação.

TABELA 30 - Massa dos elementos na cinza de carvão lixiviada

\begin{tabular}{|c|c|c|c|c|c|c|c|c|c|c|c|c|}
\hline \multirow{4}{*}{ Cinza de carvão lixiviada } & \multicolumn{12}{|c|}{ Massa do elemento $(\mathrm{mg})$} \\
\hline & \multicolumn{3}{|c|}{ As } & \multicolumn{3}{|c|}{ Mo } & \multicolumn{3}{|c|}{ Zn } & \multicolumn{3}{|c|}{ Cd } \\
\hline & \multirow{2}{*}{ Média } & \multicolumn{2}{|c|}{ Intervalo } & \multirow{2}{*}{ Média } & \multicolumn{2}{|c|}{ Intervalo } & \multirow{2}{*}{ Média } & \multicolumn{2}{|c|}{ Intervalo } & \multirow{2}{*}{ Média } & \multicolumn{2}{|c|}{ Intervalo } \\
\hline & & Máx & Mín & & Máx & Mín & & Máx & Mín & & Máx & Mín \\
\hline colunas de cinza $(n=4)$ & 53,0 & 55,2 & 50,8 & 1,3 & 1,4 & 1,2 & 28,3 & 30,7 & 25,9 & 1,4 & 1,4 & 1,3 \\
\hline colunas de solo+cinza $(n=8)$ & 53,6 & 60,0 & 47,2 & 1,4 & 1,7 & 1,1 & 26,6 & 29,7 & 23,5 & 0,9 & 1,0 & 0,7 \\
\hline
\end{tabular}

Os resultados apresentados na TAB.30 mostraram que não houve diferença representativa entre os dados obtidos para a massa dos elementos na cinza de carvão lixiviada das colunas de cinza e solo+cinza. Assim sendo, a média entre esses valores foi calculada e considerada para as subsequentes discussões (TAB.31).

Seria esperado que os valores das massas dos elementos lixiviados da cinza obtidos pelos dois métodos, somatória das massas do elemento no percolado das colunas de cinza (TAB.27) e subtração das massas da cinza não lixiviada e lixiviada (TAB.31), fossem similares, entretanto, os resultados mostraram que ocorreram diferenças entre os valores obtidos.

Para As e Mo as diferenças entre os valores médios obtidos pelos dois métodos não foram consideradas representativas (razão igual a 1,1 para ambos os elementos). Porém para o cádmio a diferença entre os valores foi maior (razão igual a 1,9) e pode ser atribuída à baixa concentração do elemento no percolado das colunas de cinza (FIG.40).

Para o $\mathrm{Zn}$ a diferença entre os valores de massa obtidos foi muito elevada (razão igual a 146), mas com base nos valores de massa obtidos pela 
subtração entre as massas da cinza não lixiviada e lixiviada (TAB.31), o Zn teria sido lixiviado da cinza. Por outro lado, o Zn teria sido pouco lixiviado da cinza com base nos valores de massa total do elemento no percolado das colunas de cinza (TAB.27). Este dado está coerente com o percentual de lixiviação do $\mathrm{Zn}$ das cinzas leves de Figueira, 0,69\%, apresentado num outro estudo (DEPOI et al., 2008).

Na montagem das colunas de cinza, conforme descrito na metodologia (item 4.3), foi utilizada uma camada de areia inerte para servir de suporte à cinza de carvão (FIG.11) e na extremidade inferior e superior da coluna de acrílico foi inserido um papel de filtro, sendo que a cinza foi adicionada sobre o papel de filtro na extremidade superior da areia. Uma hipótese que poderia ser considerada seria que o $\mathrm{Zn}$ lixiviado da cinza teria formado algum precipitado e este teria sido retido no papel de filtro. Este fato não será investigado no presente estudo.

$\mathrm{Na}$ TAB.31 a massa do elemento lixiviado da cinza de carvão, foi calculada pela subtração entre a massa do elemento na cinza não lixiviada e a massa do elemento na cinza lixiviada.

TABELA 31 - Massa dos elementos lixiviados da cinza de carvão

\begin{tabular}{|c|c|c|c|c|c|c|c|c|c|c|c|c|}
\hline \multirow{4}{*}{ Cinza de carvão } & \multicolumn{12}{|c|}{ Massa do elemento (mg) } \\
\hline & \multirow{2}{*}{\multicolumn{3}{|c|}{$\begin{array}{l}\text { As } \\
\text { Intervalo }\end{array}$}} & \multirow{3}{*}{ média } & \multirow{2}{*}{\multicolumn{2}{|c|}{$\begin{array}{l}\text { Mo } \\
\text { Intervalo }\end{array}$}} & \multirow{2}{*}{\multicolumn{4}{|c|}{$\begin{array}{l}\text { Zn } \\
\text { Intervalo }\end{array}$}} & \multirow{2}{*}{\multicolumn{2}{|c|}{$\begin{array}{l}\text { Cd } \\
\text { Intervalo }\end{array}$}} \\
\hline & & & & & & & & & & & & \\
\hline & média & Máx & Mín & & Máx & Mín & média & Máx & Mín & média & Máx & Mín \\
\hline Não lixiviada (n=2) & 81,8 & 85,0 & 78,6 & 4,1 & 4,2 & 4,0 & 38,9 & 39,8 & 38,0 & 1,9 & 1,9 & 1,8 \\
\hline Lixiviada $(n=12)$ & 53,4 & 60,0 & 47,2 & 1,4 & 1,7 & 1,1 & 27,2 & 30,7 & 25,9 & 1,0 & 1,4 & 0,7 \\
\hline $\begin{array}{l}\text { Massa do elemento lixivi } \\
\text { da cinza de carvão }\end{array}$ & 28,4 & 41,8 & 21,8 & 2,7 & 2,9 & 2,2 & 11,7 & 19,2 & 8,6 & 0,82 & 1,24 & 0,42 \\
\hline
\end{tabular}

O percentual de lixiviação dos elementos da cinza de carvão foi calculado com base nos valores médios da massa dos elementos na cinza não lixiviada (TAB.31) e na massa dos elementos lixiviados da cinza (TAB.31 e TAB.27). Na TAB.32 foi apresentado o percentual de lixiviação dos elementos da cinza de carvão considerando a massa do elemento lixiviado da cinza obtida pelos dois métodos (TAB.31 e TAB.27). 
TABELA 32 - Percentual de lixiviação dos elementos da cinza de carvão

\begin{tabular}{|c|c|c|c|c|}
\hline \multirow{2}{*}{$\begin{array}{l}\text { Massa do elemento lixiviado da cinza } \\
\text { de carvão }\end{array}$} & \multicolumn{4}{|c|}{ Percentual de lixiviação do elemento da cinza de carvão (\%) } \\
\hline & As & Mo & $\mathrm{Zn}$ & Cd \\
\hline TAB.31 & 35 & 65 & 30 & 47 \\
\hline TAB.27 & 37 & 69 & 0,20 & 23 \\
\hline
\end{tabular}

Os resultados encontrados na TAB.32 sugerem a seguinte ordem de lixiviação dos elementos da cinza de carvão: $M o>C d>A s>Z n$ com base na massa do elemento lixiviado da cinza (TAB.31) e Mo $>A s>C d>Z n$ com base na massa do elemento lixiviado da cinza (TAB.27). De qualquer maneira, o Mo foi o elemento mais lixiviado da cinza de carvão e o Zn o menos lixiviado.

Estas sequências de lixiviação dos elementos da cinza podem ser comparadas com o estudo de lixiviação dos elementos das cinzas de Figueira realizado por DEPOI et al. (2008). Embora as condições de lixiviação $(0,8 \mathrm{~g}$ de cinza e $40 \mathrm{~mL}$ de água foram misturadas mecanicamente durante $24 \mathrm{~h}$ ) utilizadas pelos autores tenham sido diferentes daquelas descritas no presente estudo, a ordem de lixiviação dos elementos nas cinzas estabelecida por eles (Mo $>A s>C d>Z n$ ) foi similar ao do presente trabalho.

\subsubsection{Concentração dos elementos no solo}

A concentração dos elementos foi determinada nos extratos do solo obtidos por digestão ácida parcial em micro ondas (denominada concentração parcial), extração com EDTA-NH 4 (denominada concentração biodisponível) e extração com $\mathrm{Ca}\left(\mathrm{NO}_{3}\right)_{2}$ (denominada concentração trocável).

\subsubsection{Concentração parcial}

A concentração parcial representa a concentração potencialmente disponível dos elementos no meio ambiente obtida pela digestão ácida parcial das amostras, conforme descrito no item 4.8.2.2.1.

Para avaliar a viabilidade da metodologia adotada (EPA 3051-A) para a determinação dos elementos $\mathrm{As}, \mathrm{Cd}, \mathrm{Zn}$ e Mo nas amostras de solo foram utilizados dois materiais de referência para solos (NIST 2709 e NIST 2711). Estes materiais de referência foram submetidos à metodologia simultaneamente com as 
amostras de solo. Os valores obtidos para a concentração dos elementos nos materiais de referência foram expostos na TAB.33.

TABELA 33 - Concentração parcial dos elementos $\left(\mathrm{mg} \mathrm{kg}^{-1}\right)$ nos extratos dos materiais de referência obtidos por digestão ácida

\begin{tabular}{|c|c|c|c|c|c|c|c|c|c|c|c|c|c|c|}
\hline \multirow{4}{*}{ Elemento } & \multicolumn{7}{|c|}{ NIST 2711} & \multicolumn{7}{|c|}{ NIST 2709} \\
\hline & \multicolumn{3}{|c|}{ Valor Indicativo } & \multicolumn{4}{|c|}{ Valor Obtido $(n=8)$} & \multicolumn{3}{|c|}{ Valor Indicativo } & \multicolumn{4}{|c|}{ Valor Obtido $(n=5)$} \\
\hline & \multirow[t]{2}{*}{$\underset{\left(\mathrm{mg} \mathrm{kg}^{-1}\right)}{\text { Valor }}$} & \multicolumn{2}{|c|}{$\begin{array}{c}\text { Intervalo } \\
\left(\mathrm{mg} \mathrm{kg}^{-1}\right)\end{array}$} & \multirow{2}{*}{$\underset{\left(\mathrm{mg} \mathrm{kg}^{-1}\right)}{\text { Média }}$} & \multirow{2}{*}{$\begin{array}{l}\text { sr } \\
(\%)\end{array}$} & \multicolumn{2}{|c|}{$\begin{array}{l}\text { Intervalo } \\
\left(\mathrm{mg} \mathrm{kg}^{-1}\right)\end{array}$} & \multirow[t]{2}{*}{$\underset{\left(\mathrm{mg} \mathrm{kg}^{-1}\right)}{\text { Valor }}$} & \multicolumn{2}{|c|}{$\begin{array}{l}\text { Intervalo } \\
\left(\mathbf{m g ~ k g}^{-1}\right)\end{array}$} & \multirow[t]{2}{*}{$\begin{array}{c}\text { Média } \\
\left(\mathrm{mg} \mathrm{kg}^{-1}\right)\end{array}$} & \multirow{2}{*}{$\begin{array}{l}\mathbf{s r} \\
(\%)\end{array}$} & \multicolumn{2}{|c|}{$\begin{array}{c}\text { Intervalo } \\
\left(\mathrm{mg} \mathrm{kg}^{-1}\right)\end{array}$} \\
\hline & & Máx & Mín & & & Máx & Mín & & Máx & Mín & & & Máx & Mín \\
\hline $\mathrm{Zn}$ & 310 & 340 & 290 & 317 & 0,6 & 319 & 315 & 100 & 120 & 87 & 85 & 1,3 & 86 & 83 \\
\hline Mo & $<2$ & - & - & $<2$ & - & - & - & $<2$ & - & - & $<2$ & - & - & - \\
\hline Cd & 40 & 46 & 32 & 30 & 0,7 & 30 & 29 & $<1$ & - & - & $<1$ & - & - & - \\
\hline As & 90 & 110 & 88 & 82 & 0,5 & 83 & 82 & $<20$ & - & - & 15 & 9,7 & 16 & 12 \\
\hline
\end{tabular}

Os valores de concentração obtidos experimentalmente nos materiais de referência (TAB.33) apresentaram-se dentro ou próximo do intervalo estabelecido para estes materiais. No caso dos valores que se apresentaram próximos do intervalo estabelecido, a diferença destes valores com o valor mínimo estabelecido foi menor que 10\%. De maneira geral, o método para a determinação dos elementos no material de referência apresentou uma boa reprodutibilidade, no qual o maior desvio padrão relativo variou de 0,5 a 9,7\% (TAB.33).

As médias obtidas para as concentrações de $\mathrm{Zn}$, Mo, Cd e As nas amostras de solo não lixiviado e solo lixiviado das colunas de solo e solo+cinza foram descritas na TAB.34. 
TABELA 34 - Concentração parcial dos elementos $\left(\mathrm{mg} \mathrm{kg}^{-1}\right)$ nos extratos do solo não lixiviado e lixiviado obtidos pela digestão ácida parcial

\begin{tabular}{|c|c|c|c|c|c|c|c|c|c|c|c|c|c|}
\hline \multirow{3}{*}{ Elemento } & \multirow{3}{*}{$\begin{array}{c}\text { Tempo } \\
\text { (dias) }\end{array}$} & \multicolumn{4}{|c|}{$\begin{array}{c}\text { Solo } \\
\text { Não lixiviado }\end{array}$} & \multicolumn{8}{|c|}{ Solo lixiviado } \\
\hline & & \multirow{2}{*}{$\begin{array}{c}\text { Média } \\
\left(\mathrm{mg} \mathrm{kg}^{-1}\right)\end{array}$} & \multirow{2}{*}{$\begin{array}{l}\mathbf{s r} \\
(\%)\end{array}$} & \multicolumn{2}{|c|}{$\begin{array}{l}\text { Intervalo } \\
\left(\mathrm{mg} \mathrm{kg}^{-1}\right)\end{array}$} & \multirow{2}{*}{$\begin{array}{c}\text { Média } \\
\left(\mathrm{mg} \mathrm{kg}^{-1}\right)\end{array}$} & \multirow{2}{*}{$\begin{array}{l}\mathbf{s r} \\
(\%)\end{array}$} & \multicolumn{2}{|c|}{$\begin{array}{l}\text { Intervalo } \\
\left(\mathrm{mg} \mathrm{kg}^{-1}\right)\end{array}$} & \multirow{2}{*}{$\begin{array}{c}\text { Média } \\
\left(\mathrm{mg} \mathrm{kg}^{-1}\right)\end{array}$} & \multirow{2}{*}{$\begin{array}{l}\mathbf{s r} \\
(\%)\end{array}$} & \multicolumn{2}{|c|}{$\begin{array}{l}\text { Intervalo } \\
\left(\mathrm{mg} \mathrm{kg}^{-1}\right)\end{array}$} \\
\hline & & & & Máx & Mín & & & Máx & Mín & & & Máx & Mín \\
\hline \multirow{3}{*}{$\mathrm{Zn}$} & 0 & $5,4(n=2)$ & 6,6 & 5,6 & 5,1 & - & - & - & - & - & - & - & - \\
\hline & 168 & - & - & - & - & $6,1(n=4)$ & 18,0 & 7,3 & 4,7 & $8,4(n=4)$ & 22,0 & 10,3 & 6,8 \\
\hline & 336 & - & - & - & - & $5,3(n=4)$ & 10,9 & 5,8 & 4,5 & $8,7(n=4)$ & 9,4 & 9,4 & 7,5 \\
\hline \multirow{3}{*}{ Mo } & 0 & $<20(n=2)$ & - & - & - & - & - & - & - & - & - & - & - \\
\hline & 168 & - & - & - & - & $<20(n=4)$ & - & - & - & $<20(n=4)$ & - & - & - \\
\hline & 336 & - & - & - & - & $<20(n=4)$ & - & - & - & $<20(n=4)$ & - & - & - \\
\hline \multirow{3}{*}{$\mathrm{Cd}$} & 0 & $<1(n=2)$ & - & - & - & - & - & - & - & - & - & - & - \\
\hline & 168 & - & - & - & - & $<1(n=4)$ & - & - & - & $1,2(n=4)$ & 4,1 & 1,3 & 1,2 \\
\hline & 336 & - & - & - & - & $<1(n=4)$ & - & - & - & $1,3(n=1)$ & - & - & - \\
\hline \multirow{3}{*}{ As } & 0 & $<5(n=2)$ & - & - & - & - & - & - & - & - & - & - & - \\
\hline & 168 & - & - & - & - & $<5(n=4)$ & - & - & - & $61,4(n=4)$ & 0,9 & 62,0 & 60,6 \\
\hline & 336 & - & - & - & - & $<5(n=4)$ & - & - & - & $59,6(n=4)$ & 3,7 & 61,7 & 56,8 \\
\hline
\end{tabular}

$\mathrm{n}=$ número de amostras e $\mathrm{sr}=$ desvio padrão relativo

De maneira geral, o método para a determinação dos elementos no solo apresentou uma reprodutibilidade satisfatória, no qual o maior desvio padrão relativo variou de 0,9 a 22,0\% (TAB.34).

Nos resultados da TAB.34 foi possível observar que o Mo não foi detectado acima do limite de quantificação do método em todas as amostras de solo, o que não era esperado, pois o Mo não foi detectado no percolado das colunas de solo+cinza (item 5.5.1.3), mas foi lixiviado da cinza de carvão conforme observado na TAB.31 e FIG.38. Por outro lado, o limite de quantificação para $\circ$ Mo no solo foi alto $\left(<20 \mathrm{mg} \mathrm{kg}^{-1}\right)$ indicando que a determinação deste elemento precisaria ser revista.

Diversos autores (GOLDBERG et al., 2007; MCBRIDE, 1994; ALLOWAY, 1990) relataram que em meio ácido, como é o caso do solo $(\mathrm{pH}=3,7)$, e oxidante o Mo encontra-se no estado de oxidação hexavalente como um oxiânion, permanecendo predominantemente retido nos óxidos hidratados amorfos de $\mathrm{Fe} \mathrm{e} \mathrm{Al,} \mathrm{mas} \mathrm{também} \mathrm{em} \mathrm{aluminossilicatos} \mathrm{e} \mathrm{argilas} \mathrm{silicatadas.}$ 
Os resultados observados para $\mathrm{Cd}$ na TAB.34 mostraram que parte desse elemento lixiviado da cinza de carvão (TAB.27 e TAB.31) ficou retida no solo, porém é importante ressaltar que as concentrações de Cd determinadas no solo (TAB.34) foram próximas do limite de quantificação do método $(<1,0 \mathrm{mg} \mathrm{kg}$ $\left.{ }^{1}\right)$. LIANG et al. (2007) estudaram o efeito da presença de arsenato na adsorção de $\mathrm{Cd}^{2+}$ em dois solos de cargas variáveis e observaram que a presença de arsenato pode levar a um aumento da adsorção de Cd em solos com óxidos de Fe e Al, quando esses estão em meio ácido, como é o caso do solo Estiva Gerbi $(\mathrm{pH}=3,7)$. ALLOWAY (1990) relatou a retenção desse elemento no solo pela presença de matéria orgânica, óxidos de ferro e manganês em valores de $\mathrm{pH}$ até 7.

Os resultados observados para As na TAB.34 mostram que parte desse elemento lixiviado da cinza de carvão (TAB.27 e TAB.31) ficou retida no solo. A retenção do arsênio no solo pode estar relacionada com a presença de óxidos hidratados de Al e Fe. ALLOWAY (1990) e MCBRIDE (1994) relataram que a lixiviação de As dos solos é inibida pela presença de óxidos hidratados de Fe e Al em meio ácido, pois ocorre formação da espécie $\mathrm{H}_{2} \mathrm{AsO}_{4}{ }^{-}\left(\mathrm{As}^{5+}\right)$, que é fortemente sorvida na superfície desses óxidos hidratados. MELO e ALLEONI (2009) descreveram que, em geral, os óxidos de Mn possuem grande quantidade de carga negativa e apresentaram forte adsorção por cátions, favorecendo a acumulação de metais. Os mesmos autores ressaltaram que óxidos de $\mathrm{Mn}$ influenciam na toxidez e disponibilidade de As nos ambientes terrestres, pois $\mathrm{As}^{3+}$ é acentuadamente adsorvido por esses óxidos a $\mathrm{pH}<6$, pois esses óxidos facilitaram a redução de $\mathrm{As}^{5+}$ para $\mathrm{As}^{3+}$ e também atuaram como oxidantes de matéria orgânica. MCBRIDE (1994) relatou que a sorção com os óxidos de Al e Fe envolve grande energia e também libera $\mathrm{OH}^{-}$para a solução do solo, ocasionando elevação do $\mathrm{pH}$, conforme exposto na equação 20 , onde $\mathrm{M}$ é uma superfície hidroxilada.

$-\mathrm{M}-\mathrm{OH}+\mathrm{H}_{2} \mathrm{AsO}_{4}^{-} \leftrightarrow-\mathrm{M}-\mathrm{H}_{2} \mathrm{AsO}_{4}+\mathrm{OH}^{-}$

SELIM e SPARKS (2001) relataram que a adsorção/dessorção de As em solos pode estar relacionada aos minerais argilosos, calcita, óxidos e 
hidróxidos de $\mathrm{Fe}$, Al e Mn, matéria orgânica e à presença de outros ânions (sulfatos, fosfatos e carbonatos).

Os resultados observados para $\mathrm{Zn}$ (TAB.34) indicaram que parte do elemento lixiviado da cinza de carvão (TAB.27 e TAB.31) ficou retida no solo após a lixiviação e que a lixiviação não apresentou diminuição representativa da concentração de Zn do próprio solo.

Não foram observadas diferenças representativas entre os períodos de 168 e 336 dias nos valores apresentados para a concentração dos elementos no solo lixiviado (TAB.34), ou seja, os elementos foram predominantemente retidos nos primeiros 168 dias de lixiviação das colunas. Assim sendo, foram calculadas as médias das concentrações dos elementos considerando os dois períodos de lixiviação,168 e 336 dias, para as discussões subsequentes.

Os elementos majoritários também foram determinados nas amostras de solo por digestão ácida, porém esses dados não foram utilizados no presente estudo e foram apresentados na TAB.2A do APÊNDICE 1.

\subsubsection{Massa do elemento no solo (ms)}

Para obter os resultados em massa $(\mathrm{mg})$ do elemento presente no solo, as concentrações dos elementos nos extratos de solo $\left(\mathrm{mg} \mathrm{kg}^{-1}\right)$ obtidos por digestão ácida (TAB.34) foram multiplicadas pela massa de solo seca acondicionada nas colunas $(0,286 \mathrm{~kg})$.

$\mathrm{Na}$ TAB.35 foi apresentada a massa de As, Mo, $\mathrm{Zn}$ e $\mathrm{Cd}$ no solo lixiviado após 336 dias de lixiviação.

TABELA 35 - Massa dos elementos no solo lixiviado

\begin{tabular}{|c|c|c|c|c|c|c|c|c|c|c|c|c|}
\hline \multirow{4}{*}{ Solo lixiviado } & \multicolumn{12}{|c|}{ Massa dos elementos (mg) } \\
\hline & \multicolumn{3}{|c|}{ As } & \multicolumn{3}{|c|}{ Mo } & \multicolumn{3}{|c|}{$\mathrm{Zn}$} & \multicolumn{3}{|c|}{ Cd } \\
\hline & \multirow{2}{*}{ Média } & \multicolumn{2}{|c|}{ Intervalo } & \multirow{2}{*}{ Média } & \multicolumn{2}{|c|}{ Intervalo } & \multirow{2}{*}{ Média } & \multicolumn{2}{|c|}{ Intervalo } & \multirow{2}{*}{ Média } & \multicolumn{2}{|c|}{ Intervalo } \\
\hline & & Máx & Mín & & Máx & Mín & & Máx & Mín & & Máx & Mín \\
\hline Colunas de solo & $<\mathrm{LQ}(\mathrm{n}=8)$ & - & - & $<\mathrm{LQ}(\mathrm{n}=8)$ & - & - & $1,62(n=8)$ & 2,09 & 1,29 & $<L Q(n=8)$ & - & - \\
\hline $\begin{array}{l}\text { Colunas de } \\
\text { solo+cinza }\end{array}$ & $17,3(n=8)$ & 17,7 & 17,3 & $<L Q(n=8)$ & - & - & $0,82(n=8)$ & 1,33 & 0,33 & $0,35(n=5)$ & 0,372 & 0,343 \\
\hline
\end{tabular}


Com base nos resultados da TAB.35 foi possível observar que o $\mathrm{Cd}$ e As ficaram retidos no solo e que a massa de $\mathrm{Zn}$ encontrada no solo lixiviado pode ser proveniente do próprio solo, visto que, os intervalos de massa de $\mathrm{Zn}$ nas colunas de solo e solo+cinza lixiviadas se intersectam, fato que está de acordo com a baixa massa de $\mathrm{Zn}$ encontrada no percolado das colunas de cinza (TAB.27).

O percentual de retenção dos elementos no solo foi calculado com base na massa total dos elementos no percolado das colunas de cinza (TAB.27). Essa massa foi selecionada por representar mais adequadamente a massa de elemento lixiviado da cinza que foi inserida na coluna de solo+cinza. O percentual de retenção dos elementos no solo foi apresentado na TAB.36.

TABELA 36 - Percentual de retenção dos elementos no solo

\begin{tabular}{cc}
\hline \multicolumn{2}{c}{ Percentual de retenção dos elementos no solo (\%) } \\
As & 81 \\
\hline 58 & 81 \\
\hline
\end{tabular}

Os resultados apresentados na TAB.36 mostram que $\mathrm{Cd}$ foi mais retido no solo do que o As. O percentual do Mo e Zn não foi apresentado na TAB.36 devido a concentração do Mo estar abaixo do limite de quantificação do método e do Zn ser proveniente do próprio solo, como já foi descrito anteriormente.

\subsubsection{Comparação entre a concentração dos elementos no solo e o valor de referência ambiental}

Na TAB.37 foi apresentada a concentração média dos elementos tóxicos no solo das colunas de solo+cinza após lixiviação de 336 dias, bem como os valores de referência e intervenção para solos do Estado de São Paulo estabelecidos pela CETESB (2005). 
TABELA 37 - Concentração média dos elementos no solo das colunas de solo+cinza após lixiviação de 336 dias e valores orientadores para solos do Estado de São Paulo (CETESB, 2005)

\begin{tabular}{cccc}
\hline \multicolumn{3}{c}{ Valores orientadores para solos (CETESB, 2005) $\left(\mathbf{m g ~ k g}^{-1}\right)$} & $\begin{array}{c}\text { Concentração no solo } \\
\text { lixiviado }\end{array}$ \\
Elemento & $\begin{array}{c}\text { Valor de Referência de } \\
\text { Qualidade (VRQ) }\end{array}$ & $\begin{array}{c}\text { Valor de Intervenção (VI) } \\
\text { para área agrícola }\end{array}$ & $\begin{array}{c}\text { (colunas de solo+cinza) } \\
\left(\mathbf{m g ~ k g}^{-1}\right)\end{array}$ \\
\hline As & 3.5 & 35 & $60,5 \pm 1,8(\mathrm{n}=8)$ \\
$\mathrm{Cd}$ & $<0.5$ & 3 & $1,2 \pm 0,1(\mathrm{n}=5)$ \\
$\mathrm{Zn}$ & 60 & 450 & $8,5 \pm 1,3(\mathrm{n}=8)$ \\
Mo & $<4$ & 50 & $<20(\mathrm{n}=8)$ \\
\hline $\mathrm{n}=$ número
\end{tabular}

Os dados da TAB.37 indicaram que as concentrações de As e Cd no solo apresentaram-se acima do valor de referência de qualidade (VRQ). De acordo com a CETESB (2005), o VRQ representa a máxima concentração de um elemento ou substância no solo que define o solo como limpo.

Não foi possível avaliar a concentração do Mo, pois não foram detectadas concentrações acima do limite de quantificação do método. As concentrações de $\mathrm{Zn}$ apresentaram-se abaixo do VRQ.

$\mathrm{O}$ As foi o único elemento que excedeu o valor de intervenção $(\mathrm{VI})$ para área agrícola. De acordo com a CETESB (2005), um elemento ou substância com concentrações acima do VI no solo representam risco potencial à saúde humana, indicando a necessidade de ações para remediação do solo. Dessa maneira, dentre os elementos determinados no solo o As pode ser considerado o mais crítico do ponto de vista ambiental e de saúde pública.

É importante ressaltar que os valores obtidos no presente estudo foram referentes à proporção de $50 \mathrm{~g}$ de cinza de carvão em $286 \mathrm{~g}$ de solo seco, ou seja, uma proporção cinza:solo de aproximadamente 1:6 e que variações nessa proporção poderiam resultar em valores distintos dos obtidos.

\subsubsection{Concentração biodisponível}

Para avaliar a viabilidade da metodologia adotada (item 4.8.2.2.2) para a determinação da concentração biodisponível dos elementos As, Cd, Zn e Mo nas amostras de solo, uma amostra de material de referência para solo (BCR 
484) foi submetida à metodologia simultaneamente com as amostras do solo, porém o certificado apresenta valores apenas para Cd e Zn.

Os resultados obtidos para o material de referência foram expostos na

TAB.38.

TABELA 38 - Concentração biodisponível dos elementos ( $\mathrm{mg} \mathrm{kg}^{-1}$ ) nos extratos do material de referência para solo (BCR 484) obtidos pela extração com EDTA-

\begin{tabular}{|c|c|c|c|c|c|c|c|}
\hline \multirow{3}{*}{ Elemento } & \multicolumn{3}{|c|}{$\begin{array}{c}\text { BCR } 484 \\
\text { Valor certificado }\end{array}$} & \multicolumn{4}{|c|}{$\begin{array}{c}\text { BCR } 484 \\
\text { Valor Obtido }(n=4)\end{array}$} \\
\hline & \multirow[t]{2}{*}{ Valor } & \multicolumn{2}{|c|}{ Intervalo } & \multirow{2}{*}{ Valor } & \multirow{2}{*}{ sr (\%) } & \multicolumn{2}{|c|}{ Intervalo } \\
\hline & & Máx & Mín & & & Máx & Mín \\
\hline Zn & 152 & 159 & 145 & 145 & 9,5 & 159 & 133 \\
\hline Mo & - & - & - & $<4$ & - & - & - \\
\hline Cd & 0,51 & 0,54 & 0,48 & 0,40 & 12,7 & 0,45 & 0,35 \\
\hline As & - & - & - & $<1$ & - & - & - \\
\hline
\end{tabular}

$\mathrm{n}=$ número de amostras e $\mathrm{sr}=$ desvio padrão relativo

Os valores de concentração obtidos experimentalmente no material de referência (BCR 484) apresentaram-se dentro ou próximo do intervalo estabelecido para este material, para $\mathrm{Zn}$ e $\mathrm{Cd}$, respectivamente (TAB.38). No caso do valor de $\mathrm{Cd}$, que se apresentou próximo do intervalo estabelecido, a diferença deste valor com o valor mínimo estabelecido foi menor que $17 \%$. 0 maior desvio padrão relativo variou de 9,5 a 12,7\%. Sendo assim, a metodologia foi considerada satisfatória para a determinação da concentração biodisponível dos elementos $\mathrm{Zn}$ e Cd.

Os resultados obtidos para a concentração biodisponível dos elementos na amostra de solo lixiviado foram expostos na TAB.39. 
TABELA 39 - Concentração biodisponível dos elementos $\left(\mathrm{mg} \mathrm{kg}^{-1}\right)$ no solo obtida pela extração com EDTA-NH $\mathrm{NH}_{4}$ após lixiviação

\begin{tabular}{|c|c|c|c|c|c|c|c|c|}
\hline \multirow{4}{*}{ Elemento } & \multicolumn{8}{|c|}{ Solo lixiviado } \\
\hline & \multicolumn{4}{|c|}{ Colunas de solo $(n=4)$} & \multicolumn{4}{|c|}{ Colunas de solo+cinza $(n=8)$} \\
\hline & \multirow{2}{*}{$\begin{array}{c}\text { Média } \\
\left(\mathrm{mg} \mathrm{kg}^{-1}\right)\end{array}$} & \multirow{2}{*}{ sr (\%) } & \multicolumn{2}{|c|}{$\begin{array}{l}\text { Intervalo } \\
\left(\mathbf{m g ~ k g}^{-1}\right)\end{array}$} & \multirow{2}{*}{$\begin{array}{c}\text { Média } \\
\left(\mathbf{m g ~ k g}^{-1}\right)\end{array}$} & \multirow{2}{*}{$\operatorname{sr}(\%)$} & \multicolumn{2}{|c|}{$\begin{array}{l}\text { Intervalo } \\
\left(\mathbf{m g ~ k g}^{-1}\right)\end{array}$} \\
\hline & & & Máx & Mín & & & Máx & Mín \\
\hline $\mathrm{Zn}$ & 0,52 & 20,0 & 0,64 & 0,39 & 2,23 & 38,0 & 3,70 & 1,08 \\
\hline Mo & $<4$ & & - & - & $<4$ & - & - & - \\
\hline Cd & $<0,2$ & & - & - & $<0,2$ & - & - & - \\
\hline As & $<1$ & & - & - & $<1$ & - & - & - \\
\hline
\end{tabular}

$\mathrm{n}=$ número de amostras e $\mathrm{sr}=$ desvio padrão relativo

O Cd, As e Mo não foram detectados no solo acima do limite de quantificação do método (TAB.39), indicando que essa metodologia não foi eficaz para extração desses elementos no solo.

Pôde-se notar que a concentração de $\mathrm{Zn}$ no solo das colunas de solo+cinza foi maior do que a do solo das colunas de solo. Este resultado foi coerente com o obtido para a concentração parcial deste elemento (TAB.34), na qual a concentração do $\mathrm{Zn}$ no solo das colunas de solo+cinza também foi maior do que a do solo das colunas de solo.

\subsubsection{Concentração trocável}

A extração dos elementos do solo com $\mathrm{Ca}\left(\mathrm{NO}_{3}\right)_{2}$ não foi realizada mediante ao uso de uma amostra de solo certificado por ser desconhecido um material de referência de solo para essa extração. A concentração trocável do $\mathrm{Zn}$ foi apresentada na TAB.40. Os elementos $\mathrm{Cd}$, Mo e As não foram reportados na TAB.40, pois os valores obtidos foram inconsistentes e por isso não foram considerados para discussão.

TABELA 40 - Concentração trocável de $\mathrm{Zn}\left(\mathrm{mg} \mathrm{kg}^{-1}\right)$ nos extratos do solo obtidos pela extração com $\mathrm{Ca}\left(\mathrm{NO}_{3}\right)_{2}$ após lixiviação

\begin{tabular}{|c|c|c|c|c|c|c|c|c|}
\hline \multirow{4}{*}{ Elemento } & \multicolumn{8}{|c|}{ Solo lixiviado } \\
\hline & \multicolumn{4}{|c|}{ Colunas de solo $(n=4)$} & \multicolumn{4}{|c|}{ Colunas de solo+cinza $(n=8)$} \\
\hline & \multirow[t]{2}{*}{$\begin{array}{c}\text { Média } \\
\left(\mathrm{mg} \mathrm{kg}^{-1}\right)\end{array}$} & \multirow{2}{*}{ sr (\%) } & \multicolumn{2}{|c|}{$\begin{array}{l}\text { Intervalo } \\
\left(\mathrm{mg} \mathrm{kg}^{-1}\right)\end{array}$} & \multirow{2}{*}{$\begin{array}{l}\text { Média } \\
\left(\mathrm{mg} \mathrm{kg}^{-1}\right)\end{array}$} & \multirow{2}{*}{$\operatorname{sr}(\%)$} & \multicolumn{2}{|c|}{$\begin{array}{l}\text { Intervalo } \\
\left(\mathbf{m g ~ k g}^{-1}\right)\end{array}$} \\
\hline & & & Máx & Mín & & & Máx & Mín \\
\hline Zn & 0,55 & 29,7 & 0,78 & 0,42 & 2,23 & 31,7 & 2,98 & 0,98 \\
\hline
\end{tabular}


Os resultados obtidos para $\mathrm{Zn}$ (TAB.40) apresentaram valores similares com aqueles obtidos por extração com EDTA (TAB.39). É esperado que os valores de $\mathrm{Zn}$ obtidos por extração com $\mathrm{Ca}\left(\mathrm{NO}_{3}\right)_{2}$ sejam iguais ou abaixo daqueles obtidos para a extração com EDTA- $\mathrm{NH}_{4} \quad 0,05 \mathrm{~mol} \mathrm{~L}^{-1}$, visto que o $\mathrm{Ca}\left(\mathrm{NO}_{3}\right)_{2}$ 0,1 mol L-1 extrai elementos das frações solúvel e trocável, ao passo que os agentes quelantes fortes, como EDTA, extrai elementos das frações solúvel, trocável, orgânica e parcialmente da fração óxidos.

$\mathrm{O}$ fato dos resultados obtidos para $\mathrm{Zn}$ pela extração com $\mathrm{Ca}\left(\mathrm{NO}_{3}\right)_{2}$ (TAB.40) apresentarem valores similares com aqueles obtidos na extração com EDTA indicou que possivelmente esse elemento foi retido no solo predominantemente na fração trocável do solo por interações eletrostáticas nas cargas dos colóides do solo por reações de troca iônica. Segundo McBRIDE (1994) o zinco está no solo como cátion bivalente e tem mobilidade média em meio ácido, sendo que pode sofrer reações de troca iônica com os cátions presentes nos colóides do solo, ligado a matéria orgânica ou ainda estar como íon solúvel.

ALLOWAY (1990) relatou que o $\mathrm{Zn}$ pode estar distribuído nas mais diferentes frações do solo, tais como, frações solúveis e trocáveis, argilas oriundas de minerais secundários, óxidos metálicos insolúveis, adsorvido ou complexado em ligantes orgânicos e em minerais primários.

Os métodos de extração com EDTA e $\mathrm{Ca}\left(\mathrm{NO}_{3}\right)_{2}$ utilizados neste estudo para os demais elementos $\mathrm{Mo}, \mathrm{Cd}$ e As deverão ser reavaliados em estudos futuros.

\subsection{Tratamento dos dados}

\subsubsection{Coeficiente de partição}

O coeficiente de partição $(K p)$ é a razão entre a concentração do elemento na fase sólida do solo em $\mathrm{mg} \mathrm{kg}^{-1}$ e a concentração do elemento na fase líquida do solo em $\mathrm{mg} \mathrm{L}^{-1}$. 
Os elementos que tendem a ficar mais retidos na fase sólida do solo apresentam valores de $\mathrm{Kp}$ mais elevados que de outros elementos que tendem a ficar na solução do solo e que, portanto, são os mais móveis.

O $\mathrm{Kp}$ foi determinado somente para o $\mathrm{Zn}$, pois apenas o $\mathrm{Zn}$ foi detectado nos extratos do solo obtidos por EDTA e $\mathrm{Ca}\left(\mathrm{NO}_{3}\right)_{2}$ (itens 5.5.5.4 e 5.5.5.5), nos quais esses extratos poderiam representar a fase líquida do solo.

O Kp $p_{\text {EDTA }}$ foi determinado pela razão entre a concentração parcial do Zn obtida por digestão ácida (TAB.34) e a concentração biodisponível obtida com EDTA-NH 4 0,05 mol L-1 (TAB.39) conforme equação 11 (item 4.9.1). O Kp $\mathrm{Ca}_{\mathrm{NO}(\mathrm{N}) 2}$ foi determinado pela razão entre a concentração parcial do Zn obtida por digestão ácida (TAB.34) e a concentração trocável obtida com $\mathrm{Ca}\left(\mathrm{NO}_{3}\right)_{2}$ 0,1 mol $\mathrm{L}^{-1}$ (TAB.40) conforme equação 12 (item 4.9.1).

Os valores de $\mathrm{Kp}_{\mathrm{EDTA}}$ e $\mathrm{Kp}_{\mathrm{Ca}(\mathrm{NO})_{2} 2}$ obtidos foram expostos na TAB.41.

TABELA 41 - Valores de Kp obtidos para o Zn

\begin{tabular}{|c|c|c|c|c|c|c|}
\hline \multirow{3}{*}{ Amostra de solo lixiviado } & \multicolumn{3}{|c|}{$\mathrm{Kp}_{\text {EDTA }}\left(\mathbf{L} \mathbf{k g}^{-1}\right)$} & \multirow{2}{*}{\multicolumn{3}{|c|}{$\mathrm{Kp}_{\mathrm{Ca}(\mathrm{NO}) 22}\left(\mathrm{~L} \mathrm{~kg}^{-1}\right)$}} \\
\hline & \multirow{2}{*}{ Média } & \multicolumn{2}{|c|}{ Intervalo } & & & \\
\hline & & Máx & Mín & Média & Máx & Mín \\
\hline colunas de solo $(n=4)$ & 224 & 260 & 172 & 217 & 241 & 154 \\
\hline colunas de solo+cinza $(n=8)$ & 85 & 122 & 54 & 83 & 118 & 58 \\
\hline
\end{tabular}

Os resultados obtidos na TAB.41 indicaram que os valores de $\mathrm{Kp}_{\mathrm{EDTA}}$ do $\mathrm{Zn}$ obtidos para o solo lixiviado (colunas de solo e solo+cinza) foram similares

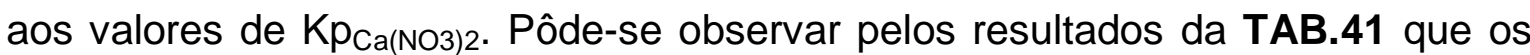
valores de $\mathrm{Kp}_{\text {EDTA }}$ e de $\mathrm{Kp}_{\mathrm{Ca}(\mathrm{NO}) 2}$ obtidos para o solo lixiviado das colunas de solo+cinza foram inferiores daqueles obtidos para o solo lixiviado das colunas de solo, indicando que a cinza de carvão diminuiu a capacidade de retenção de $\mathrm{Zn}$ no solo.

Como o coeficiente de partição foi determinado apenas para o $\mathrm{Zn}$, não foi possível estabelecer uma ordem de afinidade dos elementos $\mathrm{Zn}$, As, Cd, e Mo no solo utilizando-se esse parâmetro. 


\subsubsection{Especiação dos elementos tóxicos}

A especiação dos elementos no percolado das colunas foi realizada com o objetivo de se simular as espécies químicas presentes na solução do solo de um solo com cinza de carvão, pois a toxicidade dos elementos em estudo está diretamente relacionada com a forma química e estado de oxidação desses elementos. O conhecimento das espécies presentes na solução do solo pode também contribuir com indicativos do tipo de interação desses elementos com o solo.

Os resultados das propriedades químicas e concentração dos elementos obtidos para as amostras de percolado das colunas de solo lixiviadas (itens 5.3 e 5.5.1) foram inseridos no modelo hidrogeoquímico do programa de computação PHREEQC (PARKHUST, 1995), com a finalidade de se estimar as concentrações das espécies aquosas iônicas e moleculares formadas no percolado das colunas, bem como, estimar o índice de saturação dos minerais.

A base de dados termodinâmicos utilizada no programa de computação PHREEQC foi a base MINTEC versão 4 e foram utilizados os valores padrões adotados pelo programa, tais como, temperatura $\left(25^{\circ} \mathrm{C}\right)$, densidade $\left(1 \mathrm{mg} \cdot \mathrm{L}^{-1}\right) \mathrm{e}$ potencial redox $(p e=4)$, que não foram determinados no percolado das colunas.

Os dados dos percolados (concentração dos elementos majoritários, ânions, concentração de As, Cd, Mo e Zn, pH, CE e CTD) das colunas de cinza referentes aos períodos de 28, 56 e 84 dias e dos percolados das colunas de solo+cinza referente aos períodos de 28 e 56 dias foram aplicados no modelo hidrogeoquímico PHREEQC. A seleção desses percolados foi com base em dois critérios principalmente, sendo estes: o balanço de cargas e a força iônica da solução.

O balanço de cargas de uma solução aquosa é dado pelo princípio da eletronegatividade que assume que as espécies iônicas numa solução eletrolítica mantenham o balanço iônico, ou seja, o balanço entre as espécies aniônicas e catiônicas (ZHU et al., 2003). A porcentagem de erro do balanço iônico foi 
calculada a partir dos valores em miliequivalentes dos ânions e cátions segundo a equação 21.

Erro $=\frac{\sum \text { cátions }-\sum \text { ânions }}{\sum \text { cátions }+\sum \text { ânions }} \times 100$

De acordo com ZHU et al. (2003), o erro percentual do balanço iônico aceitável seria $<5 \%$, porém para soluções muito diluídas, ou seja, com concentrações abaixo de 5,00 meq. $\mathrm{L}^{-1}$ esse erro pode ser maior, segundo HEM (1985). O erro considerado como aceitável no presente estudo foi $15 \%$, pois todas as amostras de percolado das colunas lixiviadas apresentaram concentrações abaixo de 5,00 meq. $\mathrm{L}^{-1}$ a partir dos 56 dias de lixiviação.

Os resultados obtidos pelo modelo PHREEQC para os percolados das colunas de cinza referentes aos elementos de As, Mo, Cd e Zn foram expostas na TAB.42.

TABELA 42 - Concentração das espécies químicas de As, Mo, Cd e Zn no percolado das colunas de cinza estimada pelo modelo PHREEQC

\begin{tabular}{|c|c|c|c|c|c|c|c|c|c|}
\hline \multirow[b]{2}{*}{ Espécie } & \multicolumn{3}{|c|}{$\begin{array}{l}28 \text { dias - Erro do balanço iônico }= \\
0,09 \%\end{array}$} & \multicolumn{3}{|c|}{$\begin{array}{c}56 \text { dias - Erro do balanço iônico = } \\
6,52 \%\end{array}$} & \multicolumn{3}{|c|}{$\begin{array}{c}84 \text { dias }- \text { Erro do balanço iônico }= \\
4,61 \%\end{array}$} \\
\hline & Molalidade & Conc. $\left(\mu \mathrm{g} \mathrm{L}^{-1}\right)$ & $\%$ & Molalidade & Conc. $\left(\mu \mathrm{g} \mathrm{L}^{-1}\right)$ & $\%$ & Molalidade & Conc. $\left(\mu \mathrm{g} \mathrm{L}^{-1}\right)$ & $\%$ \\
\hline As & & & & & & & & & \\
\hline $\mathrm{HAsO}_{4}{ }^{2-}$ & $1,409.10^{-4}$ & 10553 & 64,5 & $1,166.10^{-4}$ & 8733 & 77,3 & $6,438 \cdot 10^{-5}$ & 4822 & 75,7 \\
\hline $\mathrm{H}_{2} \mathrm{AsO}_{4}{ }^{-}$ & $7,763.10^{-5}$ & 5814 & 35,5 & $3,420.10^{-5}$ & 2562 & 22,7 & $2,064.10^{-5}$ & 1546 & 24,3 \\
\hline Mo & & & & & & & & & \\
\hline $\mathrm{MoO}_{4}{ }^{2-}$ & $4,263.10^{-5}$ & 4088 & 99,8 & $8,114 \cdot 10^{-6}$ & 778 & 99,9 & $2,190 \cdot 10^{-6}$ & 210 & 99,5 \\
\hline $\mathrm{HMoO}_{4}^{-}$ & $5,738.10^{-8}$ & 6 & 0,1 & $5,305 \cdot 10^{-9}$ & 1 & 0,1 & $1,549 \cdot 10^{-9}$ & 0,1 & 0,1 \\
\hline Cd & & & & & & & & & \\
\hline $\mathrm{Cd}^{2+}$ & $1,251.10^{-6}$ & 140 & 70,1 & $9,734.10^{-7}$ & 109 & 90,9 & $6,958 \cdot 10^{-7}$ & 78 & 96,2 \\
\hline $\mathrm{CdSO}_{4}$ & $4,847 \cdot 10^{-7}$ & 54 & 27,1 & $8,620 \cdot 10^{-8}$ & 10 & 8,0 & $2,148 \cdot 10^{-8}$ & 2 & 3,0 \\
\hline $\mathrm{Zn}$ & & & & & & & & & \\
\hline $\mathrm{Zn}^{2+}$ & $2,302.10^{-7}$ & 15 & 71,7 & $6,000 \cdot 10^{-7}$ & 39 & 89,2 & $2,314 \cdot 10^{-7}$ & 15 & 79,7 \\
\hline $\mathrm{ZnSO}_{4}$ & $8,324 \cdot 10^{-8}$ & 5 & 25,9 & $4,959 \cdot 10^{-8}$ & 3 & 7,4 & $6,666 \cdot 10^{-9}$ & 0,4 & 2,3 \\
\hline
\end{tabular}

Os resultados obtidos na TAB.42 indicaram a predominância de espécies de arsênio no estado de oxidação $\mathrm{V}\left(\mathrm{HAsO}_{4}{ }^{2-}\right.$ e $\left.\mathrm{H}_{2} \mathrm{AsO}_{4}{ }^{-}\right)$nos percolados das colunas de cinza, ou seja, o As é possivelmente lixiviado da cinza na forma desses oxiânions pentavalentes, que é menos tóxico que o As trivalente. Esse 
resultado está de acordo com o resultado encontrado por KHASHIWAKURA et al. (2010), que estudaram a remoção de As em cinza de carvão por lixiviação ácida. $\mathrm{O} \mathrm{pH}$ e o potencial redox da solução são fatores determinantes na distribuição das espécies de arsênio, conforme exposto na FIG.42.

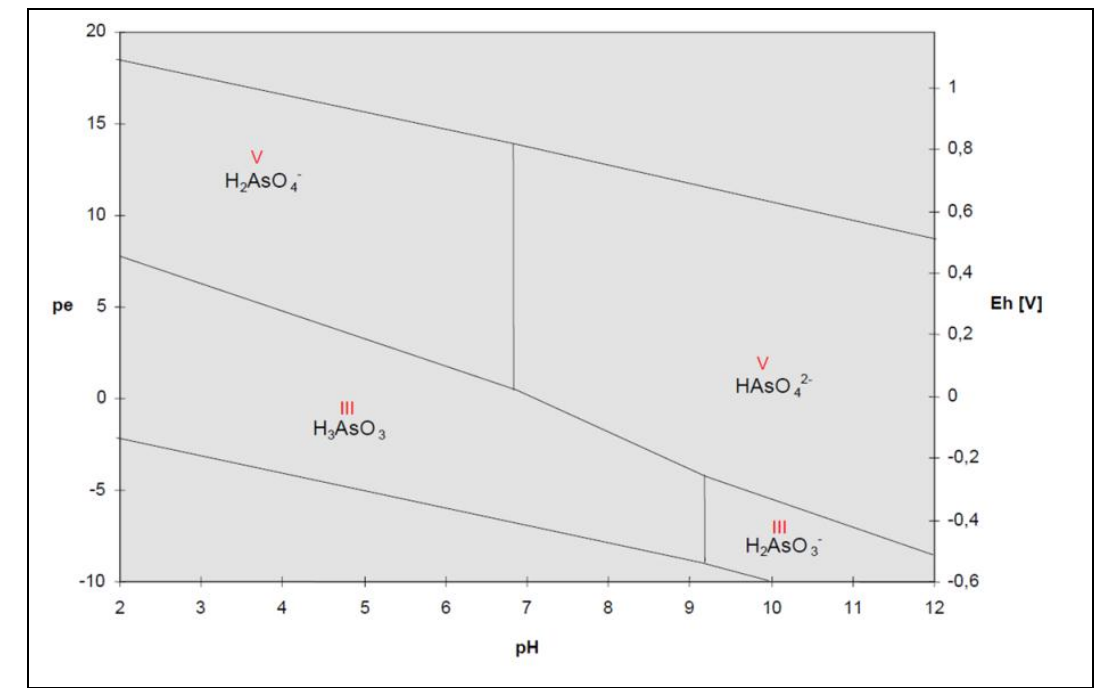

FIGURA 42 - Diagrama de estabilidade das espécies inorgânicas de arsênio (Fonte: TRETNER, 2002)

A distribuição das espécies obtidas nos percolados das colunas de cinza (TAB.42) está de acordo com as espécies ilustradas na FIG.42, considerando que esses percolados apresentaram valor de $\mathrm{pH}$ aproximado de 7,2 .

Os resultados obtidos na TAB.42 indicaram a predominância de espécies de molibdênio no estado de oxidação $\mathrm{VI}\left(\mathrm{HMoO}_{4}{ }^{-}\right.$e principalmente $\mathrm{MoO}_{4}{ }^{2-}$ ) nos percolados das colunas de cinza, ou seja, o Mo foi possivelmente lixiviado da cinza na forma desses oxiânions hexavalentes. A solubilidade desse elemento na cinza de carvão tende a ser maior em pH neutro a alcalino do que em condições ácidas, e no caso do percolado das colunas de cinza a média do $\mathrm{pH}$ foi 7,2. WARD et al. (2009) descreveram que a mobilidade do Mo na cinza de carvão leve da Austrália foi máxima em pH=6,5.

Para o cádmio os resultados encontrados (TAB.42) indicaram que esse elemento ocorre no percolado das colunas de cinza majoritariamente como cátion 
livre $\left(\mathrm{Cd}^{2+}\right)$, ou como um complexo solúvel com sulfato $\left(\mathrm{CdSO}_{4}\right)$. Esses resultados estão de acordo com os resultados encontrados por DUBIKOVA et al. (2006). O Zn apresentou um comportamento muito semelhante ao do Cd (TAB.42), ou seja, esse elemento ocorre no percolado das colunas de cinza majoritariamente como cátion livre $\left(\mathrm{Zn}^{2+}\right)$, ou como um complexo solúvel com sulfato $\left(\mathrm{ZnSO}_{4}\right)$.

O índice de saturação (IS) foi calculado pelo modelo PHREEQC por meio dos dados da análise química do percolado, sendo que, quando IS é igual a zero significa que o mineral está possivelmente em equilíbrio termodinâmico com a solução. Por outro lado, se IS é maior que zero, significa que a solução está supersaturada com esse respectivo mineral e este pode precipitar e se o IS é menor que zero significa que o mineral está possivelmente dissolvido em solução (ZHU et al., 2003).

$\mathrm{Na}$ FIG.43 foram expostos os índices de saturação dos principais minerais contendo As, Mo, Cd e $\mathrm{Zn}$ obtidos pelo modelo PHREEQC para o percolado das colunas de cinza ao longo dos 84 dias de lixiviação.

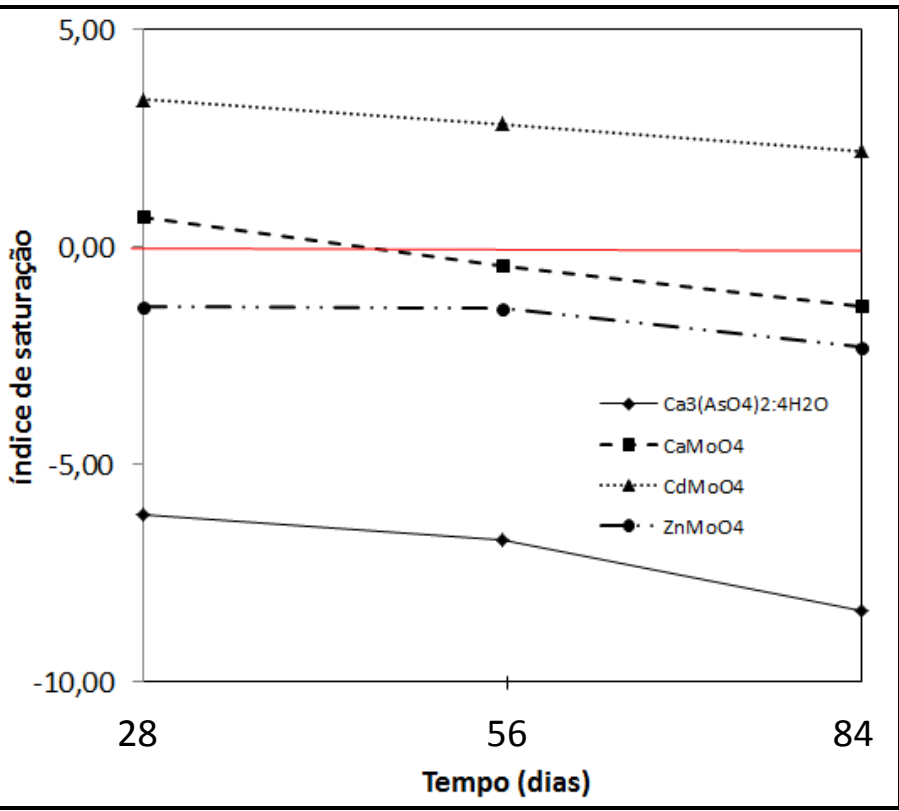

FIGURA 43 - Índices de saturação dos principais minerais contendo As, Cd, Mo e Zn no percolado das colunas de cinza

Os índices de saturação obtidos por meio do PHREEQC podem representar indicativos da presença de outros minerais que não foram detectados 
na difração de raios-X. A mineralogia da cinza de carvão determinada no item 5.1.2 apresentou fases cristalinas de quartzo $\left(\mathrm{SiO}_{2}\right)$, mulita $\left(\mathrm{Al}_{4,59} \mathrm{Si}_{1,41} \mathrm{O}_{9,7}\right)$, hematita $\left(\mathrm{Fe}_{2} \mathrm{O}_{3}\right)$ e magnesioferrita $\left(\mathrm{MgFe}_{2} \mathrm{O}_{3}\right)$. Pelo modelo PHREEQC, foi estimada a presença dos minerais que contém os elementos em estudo, sendo esses $\mathrm{Ca}_{3}\left(\mathrm{AsO}_{4}\right)_{2}: 4 \mathrm{H}_{2} \mathrm{O}, \mathrm{CaMoO}_{4}, \mathrm{CdMoO}_{4}$ e $\mathrm{ZnMoO}_{4}$ (FIG.43).

O mineral portador de $\mathrm{As}\left(\mathrm{Ca}_{3}\left(\mathrm{AsO}_{4}\right)_{2}: 4 \mathrm{H}_{2} \mathrm{O}\right)$ (FIG.43) estimado pelo modelo indicou que este mineral estaria em condições de subsaturação, ou seja, este mineral estaria dissolvido em solução. Este mineral também foi descrito como o principal mineral encontrado em outros estudos de lixiviação em cinza de carvão (KHASHIWAKURA et al., 2010; DUBIKOVA et al., 2006; QUEROL et al., 2001), nos quais os autores enfatizaram a relação entre a dissolução de Ca e As na cinza de carvão, controlando o mecanismo de precipitação desse mineral.

Os minerais $\mathrm{CdMoO}_{4}$ e $\mathrm{CaMoO}_{4}$ (FIG.43) foram encontrados pelo programa em condições de supersaturação no percolado das colunas de cinza, ou seja, esses minerais podem estar possivelmente precipitados. Nos estudos de lixiviação realizados em cinzas por DUBIKOVA et al. (2006) o mineral $\mathrm{CdMoO}_{4}$ também foi encontrado em condições de equilíbrio ou saturação nos lixiviados de cinza carvão com pH acima de 4,5.

O mineral portador de $\mathrm{Zn}$ e Mo encontrado em condições de subsaturação foi $\mathrm{ZnMoO}_{4}$ (FIG.43), ou seja, esse mineral está dissolvido no percolado das colunas de cinza.

Os resultados obtidos pelo modelo PHREEQC para os percolados das colunas de solo+cinza referentes aos elementos de As e $\mathrm{Zn}$ foram expostos na TAB.43. 
TABELA 43 - Concentração das espécies químicas de As e Zn no percolado das colunas de solo+cinza estimada pelo modelo PHREEQC

\begin{tabular}{|c|c|c|c|c|c|c|}
\hline & \multicolumn{3}{|c|}{28 dias - Erro balanço iônico = 6,28 \% } & \multicolumn{3}{|c|}{56 dias - Erro balanço iônico $=13,70 \%$} \\
\hline & Molalidade & Conc. $\left(\mu \mathrm{g} \mathrm{L}^{-1}\right)$ & $\%$ & Molalidade & Conc. $\left(\mu \mathrm{g} \mathrm{L}^{-1}\right)$ & $\%$ \\
\hline \multicolumn{7}{|l|}{ As } \\
\hline $\mathrm{H}_{3} \mathrm{AsO}_{3}$ & $8,956.10^{-8}$ & 6,7 & 95,8 & $1,534.10^{-8}$ & 1,1 & 28,7 \\
\hline $\mathrm{H}_{2} \mathrm{AsO}_{4}^{-}$ & $3,785.10^{-9}$ & 0,3 & 4,0 & $3,769.10^{-8}$ & 2,8 & 70,6 \\
\hline \multicolumn{7}{|l|}{$\mathrm{Zn}$} \\
\hline $\mathrm{Zn}^{2+}$ & $1,939.10^{-6}$ & 126,8 & 76,9 & $3,228.10^{-7}$ & 21,1 & 91,8 \\
\hline $\mathrm{ZnSO}_{4}$ & $5,622 \cdot 10^{-7}$ & 36,8 & 22,3 & $2,874.10^{-8}$ & 1,9 & 8,2 \\
\hline $\mathrm{Zn}\left(\mathrm{SO}_{4}\right)_{2}^{2-}$ & $1,93.10^{-8}$ & 1,3 & 0,8 & $1,685.10^{-10}$ & 0,0 & 0,0 \\
\hline
\end{tabular}

Diferentemente do que foi observado nos percolados das colunas de cinza (TAB.42), os resultados obtidos para a especiação de As nos percolados das colunas de solo+cinza na TAB.43 indicaram a presença de uma espécie no estado de oxidação III $\left(\mathrm{H}_{3} \mathrm{AsO}_{3}\right)$ e outra no estado de oxidação $\mathrm{V}\left(\mathrm{H}_{2} \mathrm{AsO}_{4}{ }^{-}\right)$, sendo a espécie trivalente predominante nos primeiros 28 dias de lixiviação. Tal resultado sugere que a interação do As lixiviado da cinza com o solo alterou inicialmente o estado de oxidação desse elemento de $\mathrm{As}(\mathrm{V})$ para $\mathrm{As}(\mathrm{III})$, considerado mais tóxico, porém a concentração de As obtida no percolado das colunas de solo+cinza foi da ordem de $10^{4}$ vezes inferior daquela obtida no percolado das colunas de cinza nos primeiros 84 dias de lixiviação.

Na FIG.44 foi exposto um esquema qualitativo da possível distribuição das espécies de As nos três diferentes compartimentos cinza, solo e percolado do sistema de lixiviação das colunas com base nos resultados obtidos pelo modelo PHREEQC. 


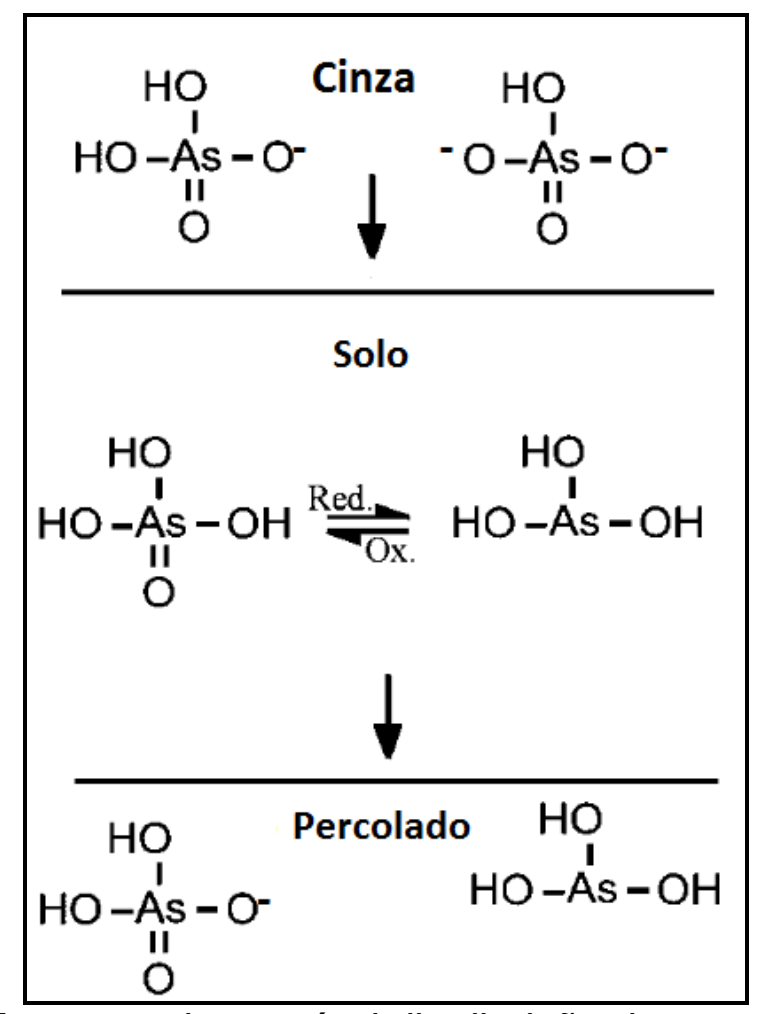

FIGURA 44 - Esquema da possível distribuição das espécies de As nos compartimentos cinza, solo e percolado do sistema de lixiviação das colunas, com base nos resultados obtidos pelo modelo PHREEQC

O Zn apresentou no percolado das colunas de solo+cinza (TAB.43) especiação semelhante àquela observada no percolado das colunas de cinza (TAB.42), ou seja, esse elemento ocorre no percolado das colunas de solo+cinza majoritariamente como cátion livre $\left(\mathrm{Zn}^{2+}\right)$, ou como um complexo solúvel com sulfato $\left(\mathrm{ZnSO}_{4}\right)$. Tal resultado sugere que a interação do zinco lixiviado da cinza de carvão com o solo não alterou o comportamento das espécies de $\mathrm{Zn}$.

STEPHAN et al. (2008) estudaram a especiação de Zn em extratos de solo europeus e americanos com mais de 66 amostras de solos contaminados e chegaram a conclusão que $\mathrm{Zn}^{2+}$ correspondeu de 40 a 60\% das espécies de $\mathrm{Zn}$ dissolvidas nesses extratos e que as demais espécies dissolvidas encontradas estariam majoritariamente associadas ao carbono orgânico dissolvido (COD), Entretanto a especiação obtida pelo PHREEQC no presente trabalho corresponde apenas as espécies inorgânicas.

Todos os minerais contendo As e $\mathrm{Zn}$ nos percolados das colunas de solo+cinza (28 e 56 dias) apresentaram $I S<<<0$, sugerindo que esses minerais 
estão possivelmente bem dissolvidos e distantes de atingirem o equilíbrio químico em solução. Entretanto, outras informações relevantes quanto à mineralogia do solo foram encontradas na análise dos índices de saturação dos percolados das colunas de solo+cinza, conforme exposto na TAB.44.

TABELA 44 - Índice de saturação dos principais minerais presentes no percolado das colunas de solo+cinza obtido pelo modelo PHREEQC

\begin{tabular}{ccc}
\hline Mineral & 28 dias & Indice de Saturação (IS) \\
& 0,11 & $\mathbf{5 6}$ dias \\
\hline Quartzo $\left(\mathrm{SiO}_{2}\right)$ & $-1,04$ & $-0,19$ \\
Gibbsita $\left(\mathbf{A l}\left(\mathrm{OH}_{3}\right)\right.$ & $-0,70$ & 0,21 \\
Caulinita $\left(\mathrm{Al}_{2} \mathrm{Si}_{2} \mathrm{O}_{5}(\mathrm{OH})_{4}\right)$ & $-4,74$ & 1,20 \\
Hematita $\left(\mathrm{Fe}_{2} \mathrm{O}_{3}\right)$ & $-3,57$ & 0,66 \\
Goethita $(\mathrm{FeOOH})$ & 0,38 & $-0,87$ \\
Diasporo $(\mathbf{A l O O H})$ & 1,63 \\
\hline
\end{tabular}

Os resultados encontrados na TAB.44 indicaram que os minerais já identificados por difratometria de raios-X no solo (FIG.23) como o quartzo $\left(\mathrm{SiO}_{2}\right)$, gibbsita $\left(\mathrm{Al}(\mathrm{OH})_{3}\right)$, caulinita $\left(\mathrm{Al}_{2} \mathrm{Si}_{2} \mathrm{O}_{5}(\mathrm{OH})_{4}\right)$ e hematita $\left(\mathrm{Fe}_{2} \mathrm{O}_{3}\right)$ apresentaram-se supersaturados ou próximos do equilíbrio químico no percolado das colunas de solo+cinza, ou seja, os resultados obtidos pelo PHREEQC estão de acordo com aqueles obtidos pela difratometria de raios- $X$ do solo. Além disso, a presença de goethita $(\mathrm{FeOOH})$ e diasporo $(\mathrm{AlOOH})$ nos percolados das colunas de solo+cinza (TAB.44) foi estimada pelo modelo retornando estes minerais em condições de subsaturação e supersaturação, respectivamente, porém ambos próximos do equilíbrio químico. A presença de goethita, conforme citado anteriormente (item 5.2.2), também foi identificada por SOARES (2004) que analisou a mineralogia de solos na região de coleta do solo utilizado no presente estudo.

\subsubsection{Correlação entre os dados obtidos no percolado das colunas solo+cinza}

Os dados obtidos nos percolados das colunas de solo+cinza ao longo de 336 dias de lixiviação foram correlacionados com a finalidade de se obter indicativos sobre a mobilidade dos elementos $\mathrm{As}$ e $\mathrm{Zn}$ que foram lixiviados das colunas de solo+cinza. Na TAB.45 foi apresentado o resultado das correlações 
obtidas por uma matriz de correlação entre as concentrações de As e Zn e as propriedades químicas do percolado das colunas de solo+cinza.

TABELA 45 - Correlação da concentração de As e Zn com as propriedades físicas e químicas no percolado das colunas de solo+cinza

\begin{tabular}{|c|c|c|}
\hline & As & $\mathrm{Zn}$ \\
\hline As & 1,00 & \\
\hline Zn & $-0,23$ & 1,00 \\
\hline Al & $-0,30$ & 0,98 \\
\hline $\mathrm{Fe}$ & 0,76 & $-0,11$ \\
\hline Mn & $-0,04$ & 0,95 \\
\hline $\mathrm{Ca}$ & $-0,28$ & 0,97 \\
\hline $\mathrm{Mg}$ & $-0,26$ & 0,98 \\
\hline K & $-0,25$ & 0,98 \\
\hline $\mathrm{Na}$ & $-0,25$ & 0,98 \\
\hline Si & 0,20 & 0,63 \\
\hline $\mathrm{SO}_{4}^{2-}$ & $-0,29$ & 0,97 \\
\hline $\mathrm{NO}_{3}^{-}$ & $-0,28$ & 0,97 \\
\hline $\mathrm{F}^{-}$ & $-0,25$ & 0,96 \\
\hline $\mathrm{Cl}^{-}$ & $-0,28$ & 0,92 \\
\hline $\mathrm{pH}$ & 0,34 & $-0,68$ \\
\hline CE & $-0,30$ & 0,97 \\
\hline CT & 0,25 & 0,78 \\
\hline COD & 0,20 & 0,80 \\
\hline CID & 0,82 & $-0,27$ \\
\hline
\end{tabular}

Obs: resultados obtidos por meio de matriz de correlação considerando dados das médias obtidas no percolado das quatro réplicas das colunas de solo+cinza abrangendo os 336 dias de lixiviação. Números em vermelho e azul: ocorrência de correlações negativas e positivas, respectivamente.

$\mathrm{Na}$ TAB.45 foram considerados representativos os coeficientes de correlação que apresentaram valores maiores ou iguais a 0,60.

O pH apresentou correlação negativa $(-0,68)$ com a concentração de $\mathrm{Zn}$, ou seja, o $\mathrm{Zn}$ foi mais facilmente lixiviado do solo em $\mathrm{pH}$ mais baixo e a medida que o pH do meio aumentou a concentração de $\mathrm{Zn}$ no percolado diminuiu, conforme apresentado na FIG.45. 


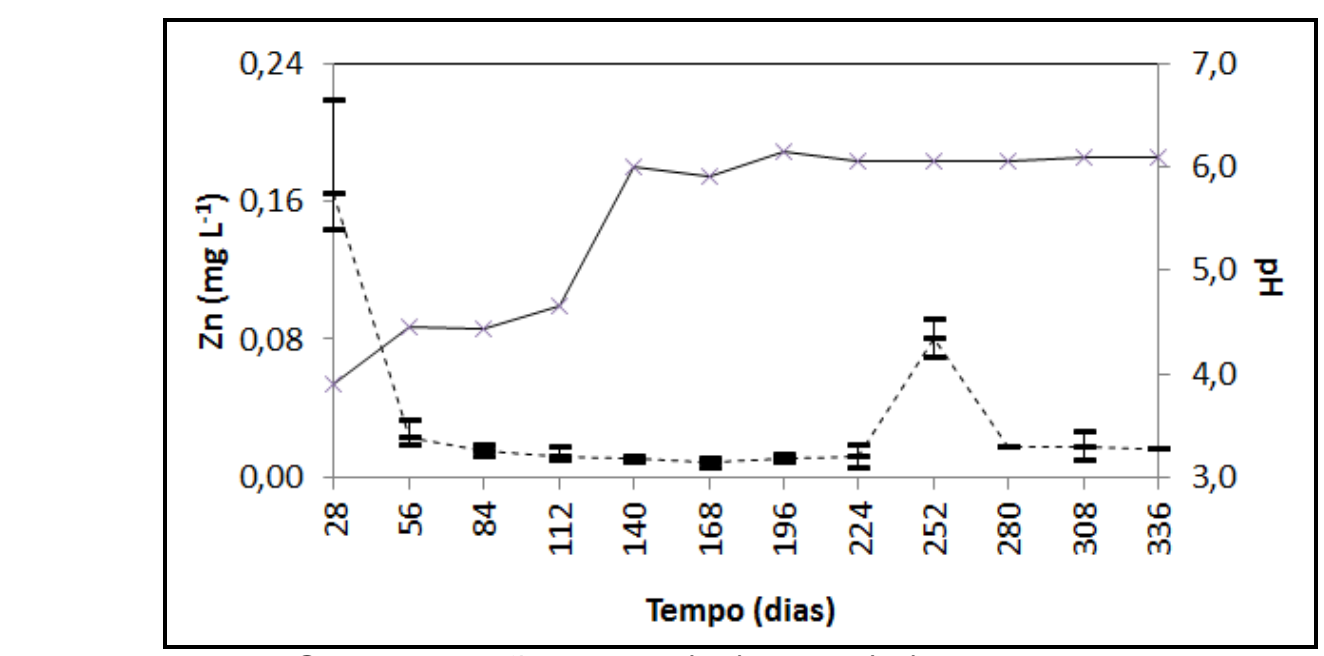

FIGURA 45 - Concentração de $\mathrm{Zn} \mathrm{(---)} \mathrm{e} \mathrm{pH} \mathrm{(-)} \mathrm{dos} \mathrm{percolados} \mathrm{das} \mathrm{colunas}$ de solo+cinza ao longo de 336 dias

Este resultado está de acordo com STEPHAN et al. (2008), YONG e MULLIGAN (2004) e ALLOWAY (1990) que reportaram que em pH baixo a adsorção de $\mathrm{Zn}$ em solos diminuiu.

A concentração de $\mathrm{Zn}$ no percolado das colunas de solo+cinza apresentou correlação positiva $(\geq 0,97)$ com os cátions trocáveis $\left(\mathrm{Na}^{+}, \mathrm{K}^{+}\right.$, $\mathrm{Ca}^{2+}, \mathrm{Mg}^{2+}$ e $\mathrm{Al}^{3+}$ ), indicando que $\circ \mathrm{Zn}^{2+}$, possivelmente oriundo do próprio solo, ligado por interações eletrostáticas, como os demais cátions trocáveis também foi lixiviado.

Os resultados apontaram para uma correlação positiva $(\geq 0,92)$ entre a concentração de $\mathrm{Zn}$ e a concentração de ânions $\left(\mathrm{SO}_{4}{ }^{2-}, \mathrm{NO}_{3}{ }^{-}, \mathrm{Cl}^{-}\right.$e $\left.\mathrm{F}^{-}\right)$, indicando que possivelmente $\mathrm{o} \mathrm{Zn}$ formou espécies solúveis com esses ânions, tais como $\mathrm{ZnSO}_{4}$ e $\mathrm{Zn}\left(\mathrm{SO}_{4}\right)_{2}{ }^{2-}$ que foram obtidas pela especiação do $Z n$ no percolado das colunas de solo+cinza estimada pelo modelo PHREEQC (TAB.43). Outras espécies solúveis de $\mathrm{Zn}$ foram estimadas pelo modelo PHREEQC, mas não foram listadas na TAB.43 por apresentarem concentrações muito baixas, sendo essas: $\mathrm{ZnCl}^{+}, \mathrm{ZnCO}_{3}, \mathrm{ZnOHCl}, \mathrm{Zn}\left(\mathrm{NO}_{3}\right)_{2}$, $\mathrm{Zn}(\mathrm{OH})_{2}$ e $\mathrm{ZnCl}_{2}$.

Os resultados apontaram para uma correlação positiva $(0,97)$ da concentração de $\mathrm{Zn}$ com a condutividade elétrica (CE), indicando que 
possivelmente o $\mathrm{Zn}$ seja um dos elementos que contribuiu para a mineralização dos percolados no início da lixiviação. Estes apresentaram um mesmo comportamento na variação da concentração do Zn (FIG.41) e da condutividade elétrica (FIG.28), diminuindo ao longo do tempo.

A concentração de carbono orgânico dissolvido (COD) apresentou correlação positiva $(0,80)$ com a concentração de $Z n$ no percolado. Tal resultado está de acordo com estudo de especiação de Zn em extratos de solo realizado por STEPHAN et al. (2008), no qual os autores descreveram que as espécies associadas ao COD variaram de 60 a $98 \%$ do total das espécies de $\mathrm{Zn}$ dissolvidas nesses extratos.

A concentração de As obtida nos percolados gerados pelas colunas de solo+cinza apresentou correlação positiva $(0,76)$ com a concentração de Fe no percolado. Tal resultado sugere que o As pode estar associado ao $\mathrm{Fe}$ do solo e que a dissolução de óxidos de Fe do solo aumenta a mobilidade de As. Diversos trabalhos relataram a afinidade do As pelos óxidos de Fe em meio ácido (LUTHER et al., 2012; ILGEN et al., 2011; MOHAN e PITTMAN JUNIOR, 2007; HÖHN et al., 2006; YOUNG e MULLIGAN, 2004; TRETNER, 2002; LUMSDOM et al., 2001). ASSIS (2010) e CAMPOS et al. (2007) estudaram a adsorção de As em latossolos brasileiros e também relataram a adsorção desse elemento por óxidos de Fe.

Conforme citado no item 5.3.3, a quantidade elevada de sulfato no percolado das colunas de solo+cinza oriundo da lixiviação da cinza (TAB.25) pode ser causador da dissolução de minerais de Fe como hematita e goethita (FIG.33) aumentando a concentração de ferro livre $\left(\mathrm{Fe}^{2+}\right.$ e $\left.\mathrm{Fe}^{3+}\right)$ que podem reagir com o As. A equação 22 exemplifica a reação entre arsenato e goethita.

$\mathrm{FeOOH}+3 \mathrm{H}_{2} \mathrm{AsO}_{4}^{-}+\mathrm{H}^{+} \leftrightarrow \mathrm{Fe}\left(\mathrm{H}_{2} \mathrm{AsO}_{4}\right)_{3}+2 \mathrm{H}_{2} \mathrm{O}$

A concentração de As obtida nos percolados gerados pelas colunas de solo+cinza apresentou correlação positiva $(0,82)$ com a concentração de 
carbono inorgânico dissolvido no percolado. Este resultado está de acordo com o observado por SELIM e SPARKS (2001) que descreveram que a mobilidade de As em solos aumenta proporcionalmente ao aumento da concentração de carbonatos.

\subsubsection{Balanço de massa}

O balanço de massa do sistema cinza/solo/percolado foi calculado com a finalidade de se verificar a contribuição da cinza de carvão quanto ao aumento das concentrações de As, Zn, Cd e Mo nas colunas de solo.

Seria esperado que os valores obtidos pela diferença entre a massa do elemento lixiviada da cinza de carvão $(m c)$, que foi determinada por dois métodos (TAB.31), e a massa do elemento retida no solo (ms) (TAB.35) fossem iguais à massa do elemento no percolado das colunas solo+cinza (mp) (TAB.27).

\subsubsection{Balanço de massa - Arsênio}

O balanço de massas do arsênio no sistema cinza/solo/percolado foi exposto na FIG.46.

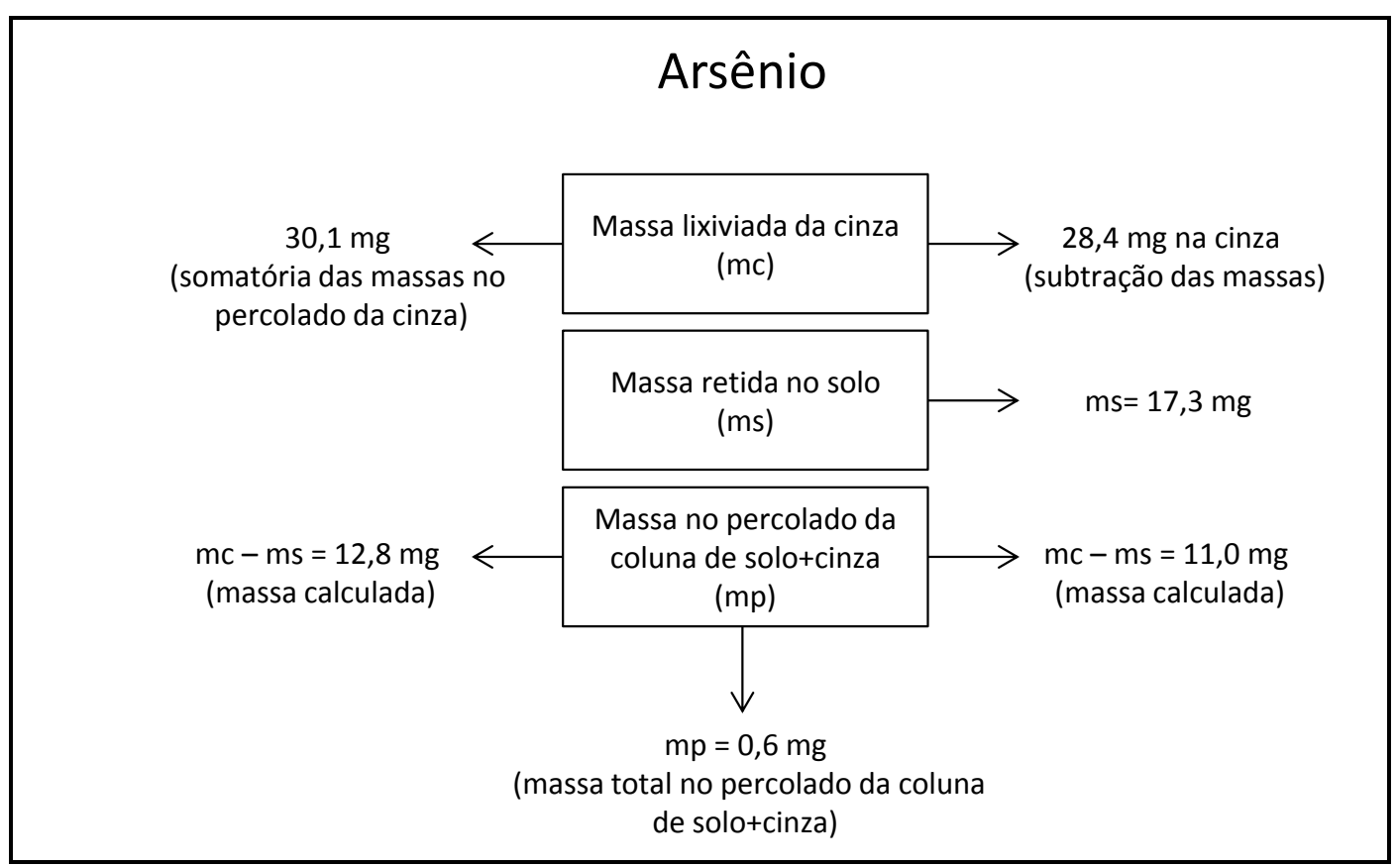

FIGURA 46 - Esquema do balanço de massa em mg de arsênio no sistema cinza/solo/percolado 
Pôde-se observar no balanço de massa de As (FIG.46) que a massa do elemento no percolado $(\mathrm{mp})$ calculada pela diferença entre as massas do elemento lixiviado da cinza $(\mathrm{mc})$ e a massa do elemento retido no solo $(\mathrm{ms})$ foi diferente da massa total do elemento obtida experimentalmente no percolado da coluna solo+cinza. O percolado apresentou uma massa de As $(0,6 \mathrm{mg})$ menor daquelas massas do elemento $(12,8 \mathrm{mg}$ e $11,0 \mathrm{mg})$ calculadas para o percolado, ou seja, o balanço de massas não apresentou o resultado esperado para o As. Isso pode ter ocorrido pela mesma hipótese do papel de filtro descrita no caso do $\mathrm{Zn}$ no item 5.5.4.1.

\subsubsection{Balanço de massa - Molibdênio}

Não foi possível efetuar o balanço de massas para Mo, visto que, esse elemento não foi detectado em concentrações acima do limite de quantificação no solo (item 5.5.5.1) e no percolado das colunas de solo+cinza conforme descrito no item 5.5.1.3.

\subsubsection{Balanço de massa - Cádmio}

O balanço de massas do cádmio no sistema cinza/solo/percolado foi exposto na FIG.47. 


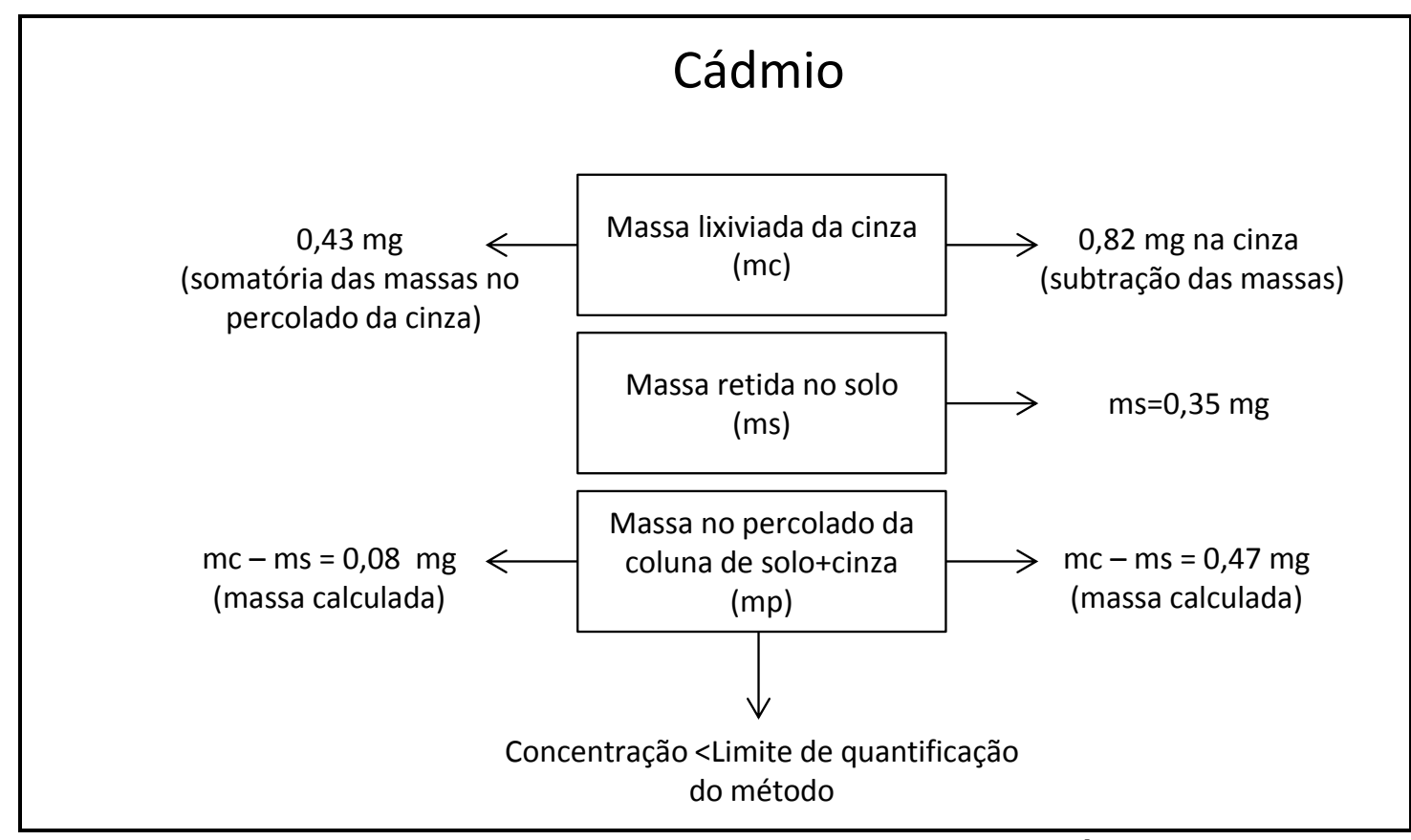

FIGURA 47 - Esquema do balanço de massa em mg de cádmio no sistema cinza/solo/percolado

A massa de $\mathrm{Cd}$ não foi detectada no percolado da coluna solo+cinza porque a concentração deste elemento no percolado foi menor que o limite de quantificação do método. Por outro lado, a massa de Cd calculada (0,08 $\mathrm{mg}$ e 0,4 mg) percolado da coluna solo+cinza foi maior daquela obtida experimentalmente. É bom ressaltar que o percolado da coluna de solo+cinza obtido experimentalmente foi submetido a uma filtração em membrana de acetato de celulose de 0,45 $\mu \mathrm{m}$ e essa membrana poderia ter retido o Cd uma vez que a massa desse elemento é pequena. O Cd poderia ter ficado retido também no papel de filtro adicionado entre a coluna de solo+cinza e o percolado desta coluna.

ISKANDAR e KIRKHAN (2001) reportaram a dificuldade na determinação da concentração de $\mathrm{Cd}$ em extratos de solos. Os autores estudaram o efeito da porosidade das membranas utilizadas para filtração dos extratos de solo, conforme exposto na FIG.48, e concluíram que o papel de filtro foi capaz de reter quantidades significativas de $\mathrm{Cd}$ mesmo na porosidade de $0,45 \mu \mathrm{m}$, seja por processos de sorção do elemento no papel ou ainda pela retenção de $\mathrm{Cd}$ na forma coloidal e que essa retenção é menos efetiva nas 
membranas de nitrato de celulose.

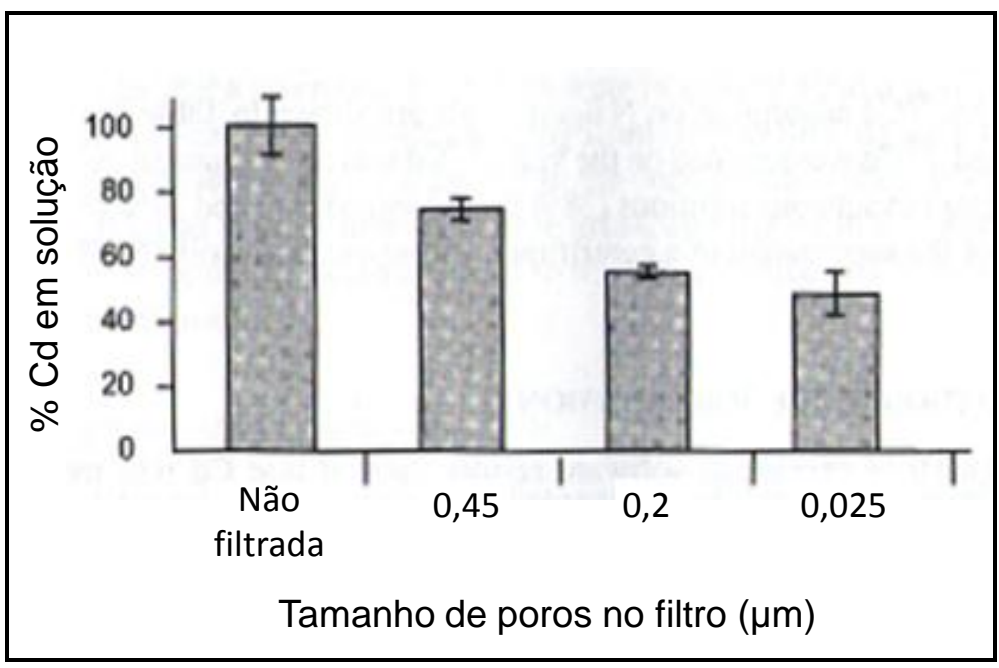

FIGURA 48 - Efeito do tamanho de poros do filtro na concentração de $\mathrm{Cd}$ em solução. Fonte: ISKANDAR e KIRKHAN (2001)

Assim como para o As, o balanço de massas para $\mathrm{Cd}$ não apresentou o resultado esperado.

\subsubsection{Balanço de massa - Zinco}

Não foi possível efetuar o balanço de massas para Zn, visto que, a massa desse elemento detectada no percolado das colunas de cinza (TAB.27) foi muito baixa $(0,08 \mathrm{mg})$. Se essa massa fosse totalmente retida no solo em estudo a concentração de $\mathrm{Zn}$ no solo seria $0,28 \mathrm{mg} \mathrm{kg}^{-1}$ e essa concentração não seria possível de ser detectada por meio da metodologia selecionada no presente estudo. 


\section{CONCLUSÕES}

- O chumbo, apesar de presente na cinza de carvão, não foi lixiviado nas condições de estudo;

- A ordem de lixiviação dos elementos da cinza de carvão obtida indicou que o Mo foi o elemento mais lixiviado em relação aos demais e o $\mathrm{Zn}$ o menos lixiviado;

- Os elementos As, Mo, $\mathrm{Cd}$ e $\mathrm{Zn}$ foram lixiviados da cinza de carvão majoritariamente nas seguintes espécies químicas: $\mathrm{HAsO}_{4}{ }^{2-}, \mathrm{H}_{2} \mathrm{AsO}_{4}{ }^{-}, \mathrm{MoO}_{4}{ }^{2-}$, $\mathrm{Cd}^{2+}, \mathrm{CdSO}_{4}, \mathrm{Zn}^{2+}$ e $\mathrm{ZnSO}_{4}$;

- A cinza de carvão influenciou na mobilidade do Zn proveniente do próprio solo;

- O Cd foi o elemento mais retido pelo solo franco arenoso, seguido de As;

- A concentração de As no solo excedeu o valor de intervenção para área agrícola;

- A correlação dos dados dos percolados das colunas de solo+cinza indicou que o As está associado aos óxidos de ferro presentes no solo;

- A presença das espécies químicas de As no estado de oxidação III $\left(\mathrm{H}_{3} \mathrm{AsO}_{3}\right)$ e outra no estado de oxidação $\mathrm{V}\left(\mathrm{H}_{2} \mathrm{AsO}_{4}{ }^{-}\right)$nos percolados das colunas de solo+cinza, indica que a interação do As lixiviado da cinza de carvão com o solo alterou o comportamento das espécies desse elemento;

- A concentração de Cd no solo excedeu o valor de qualidade de referência para solo;

- A concentração de Zn no solo não representa preocupação ambiental;

- O Zn apresentou-se majoritariamente como $\mathrm{Zn}^{2+}$ e $\mathrm{ZnSO}_{4}$ nos percolados das colunas de solo+cinza, sugerindo que a interação do zinco lixiviado da cinza de carvão com o solo não alterou o comportamento das espécies químicas desse elemento; 
- Os valores de $\mathrm{Kp}_{\text {EDTA }}$ e $\mathrm{Kp}_{\mathrm{Ca}(\mathrm{NO} 3) 2}$ obtidos para o $\mathrm{Zn}$ nas amostras de solo lixiviado indicaram que a cinza de carvão diminuiu a capacidade de retenção desse elemento no solo;

- O Zn proveniente do próprio solo está associado à fração trocável;

- O Mo apesar de ser lixiviado em maior porcentagem da cinza de carvão não foi detectado no solo e nos percolados das colunas de solo+cinza, indicando que a metodologia para detecção desse elemento deverá ser revista em trabalhos futuros. 


\section{REFERÊNCIAS BIBLIOGRÁFICAS}

ASSOCIAÇÃO BRASILEIRA DE NORMAS TÉCNICAS. Resíduos sólidos: classificação. Rio de Janeiro: ABNT, 2004. (NBR 10004)

ASSOCIAÇÃO BRASILEIRA DE NORMAS TÉCNICAS, Solo - Determinação de do teor de matéria orgânica por queima a 440 C. Rio de Janeiro: ABNT, 1996. (NBR 13360)

AGOURAKIS, D.C.; CAMARGO, I.M.C.; COTRIM, M.B.; FLUES, M. Comportamento de zinco e manganês de pilhas alcalinas em uma coluna de solo. Química Nova, v. 29, n.5, p. 960-964, 2006.

ALLOWAY, B. J. Heavy metals in soils. New York: Wiley, 1990.

ALMAS, A.R.; BAKKEN, L.R.; MULDER, J. Changes in tolerance of soil microbial communities in $\mathrm{Zn}$ and $\mathrm{Cd}$ contaminated soils. Soil Biology and Biochemistry, v.36, n.6, p. 805-813, 2004.

AGÊNCIA NACIONAL DE ENERGIA ELÉTRICA - ANEEL - disponível em: http://www.aneel.gov.br, acessado em 16/03/2011.

ART, H.W. Dicionário de Ecologia e Ciências Ambientais. $6^{\mathrm{a}}$ Ed. Companhia Melhoramentos, São Paulo, 2000.

ASSIS, I.R. Adsorção e disponibilidade de arsênio em solos com diferentes composições mineralógicas. Tese (doutorado). Universidade Federal de Viçosa, UFV, Viçosa, 2010.

BARRA, C.M.; SANTELLI, R.E.; ABRÃO, J.J.; DE LA GUARDIA, M. Especiação de arsênio - uma revisão. Química Nova, v. 23, n.1, p. 58-70, 2000.

BAIRD, C. Química Ambiental. 2ª Ed. Bookman, Porto Alegre, 2002.

BEESLEY, L.; MORENO-JIMÉNEZ, E.; CLEMENTE, R.; LEPP, N.; DICKINSON, $\mathrm{N}$. Mobility of arsenic, cadmium and zinc in a multi-element contaminated soil profile assessed by in-situ soil pore water sampling, column leaching and sequential extraction. Environmental Pollution, v.158, n.1, p. 155-160, 2010. 
BERTOLO, R.A. Hidrodinâmica e hidrogeoquímica da zona não saturada do aquífero adamantina em Urânia-SP. Tese (doutorado). Universidade de São Paulo, USP, São Paulo, 2001.

BRITISH PETROLEUM - BP. Statiscal Review of World Energy 2009, disponível em: http://www.bp.com/, acessado em 05/06/2010.

BRADY, N.C. Natureza e Propriedades dos Solos. $7^{a}$ Ed. Freitas Bastos, Rio de Janeiro, 1989.

BRAZ, A.M.S. Coeficiente de distribuição de metais pesados em solos paraenses. Tese (doutorado). Universidade de São Paulo, USP, Piracicaba, 2011.

CAMARGO, I. M. C. Estudo da influência do coeficiente de partição de metais no solo de Figueira, Paraná, no cálculo do risco à saúde humana, utilizando o modelo C-Soil. Tese (doutorado). Instituto de Pesquisas Energéticas e Nucleares - IPEN/CNEN, São Paulo, 2005.

CAMPOS, M.L.; GUILHERME, L.R.G.; LOPES, R.S.; ANTUNES, A.S.; MARQUES, J.J.G.S.M.; CURI, N. Teor e capacidade máxima de adsorção de arsênio em latossolos brasileiros. Revista Brasileira de Ciência do Solo, v.31, p. 1311-1318, 2007.

CAO, D.; SELIC, E.; HERBELL, J-D. Utilization of fly ash from coal-fired power plants in China. Journal of Zhejiang University-Science A (Applied Physics \& Engineering), v.9, n.5, p.681-687, 2008.

CARVALHO, T.E.M. Adsorção de corantes aniônicos de solução aquosa em cinza leve de carvão e zeólita de cinza leve de carvão. Tese (doutorado) Instituto de Pesquisas Energéticas e Nucleares - IPEN/CNEN, São Paulo, 2010.

COMPANHIA DE TECNOLOGIA DE SANEAMENTO AMBIENTAL, CETESB. Relatório de estabelecimento de Valores Orientadores para Solos e Águas Subterrâneas no Estado de São Paulo, R321, 2001. 
COMPANHIA DE TECNOLOGIA DE SANEAMENTO AMBIENTAL, CETESB. Valores Orientadores para Solos e Águas Subterrâneas no Estado de São Paulo. Decisão de Diretoria $n^{0}$ 195-2005, 2005. Disponível em: http://www.cetesb.sp.gov.br/media/files/Solo/relatorios/tabela_valores_2005.pdf. Acesso em: 02-Mai-2011.

CONDER, JM.; LANNO, R.P.; BASTA, N.T. Assessment of metal availability in smelter soil using earthworms and chemical extractions. Journal Environmental Quality, v.30, p.1231-1237, 2001.

DEPOI, F.S.; POZEBON, D.; KALREUTH, W. D. Chemical characterization of feed coals and combustion-by-products from Brazilian power plants. International Journal of Coal Geology, v.76, n.3, p.227-236, 2008.

DONG, D.; ZHAO, X.; HUA, X.; LUI, J.; GAO, M. Investigation of the potential mobility of $\mathrm{Pb}, \mathrm{Cd}$ and $\mathrm{Cr}(\mathrm{IV})$ from moderately contaminated farmland soil to groundwater in Northeast, China. Journal of Hazardous Material, v.162, p.12611268.

DUBIKOVA, M.; JANKOWSKI, J.; WARD, C.; FRENCH, D. Modelling element mobility in water-fly ash interactions. Co-operative Research Center for Coal in Sustainable Development, Research Report, v.61, 2006, 61 p.

DUTTA, B.K.; KHANRA, S.; MALLICK, D. Leaching of elements from coal fly ash: Assessment of its potential for use in filling abandoned coal mines. Fuel, v. 88, p. 1314-1323, 2009.

EMPRESA BRASILEIRA DE AGROPECUÁRIA, EMBRAPA. Sistema Brasileiro de Classificação de Solos. Centro Nacional de Pesquisas de Solos, Rio de Janeiro, 2006.

EMPRESA BRASILEIRA DE AGROPECUÁRIA, EMBRAPA. Manual de métodos de análise de solo. Centro Nacional de Pesquisas de Solos, Rio de Janeiro, $2^{a}$ ed., 1997. 
EMPRESA BRASILEIRA DE AGROPECUÁRIA, EMBRAPA. Sistema Brasileiro de Classificação de Solos. Centro Nacional de Pesquisas de Solos, Brasília, 1999.

FERRET, L.S. Zeólitas de cinzas de carvão: síntese e uso. Tese (doutorado). Universidade Federal do Rio Grande do Sul, Porto Alegre, 2004.

FLUES, M.; HAMA, P.; LEMES, M. J. L.; DANTAS, E. S. K.; FORNARO, A. Evaluation of the Rainwater acidity of a rural region due to a coal-fired power plant in Brazil. Atmospheric Environment, v.36 (14), p.2397-2404, 2002.

FLUES, M.; SATO, I. M.; COTRIM, M. B.; FIGUEIREDO FILHO, P. M.; CAMARGO, I. M. C. Avaliação da influência da operação da termoelétrica a carvão na concentração dos metais e As no solo de Figueira, PR-Brasil. Química Nova. v.31, n.1, p.25-30, 2008.

FREEZE, R.A., CHERRY, J.A. Groundwater. New Jersey, Prentice-Hall Inc, 1979.

GAZANO, V.S.O. Contaminação de solo por metais tóxicos provenientes do descarte inadequado de pilhas zinco-carbono de uso doméstico. Dissertação (Mestrado). Instituto de Pesquisas Energéticas e Nucleares - IPEN/CNEN, São Paulo, 2006.

GARRABRANTS, A.C.; KOSSON, D.S. Use of a chelating agente to determine the metal availability for leaching from soils and wastes. Waste Management, v.20, n. 2-3, p. 155-165, 2000.

GOLDBERG, S.; JOHNSTON C.T.; SUAREZ, D.L.; LESCH, S.M. Mechanism of Molybdenum Adorption on Soils and Soil Minerals Evaluated Usind Vibrational Spectroscopy and Surface Complexation Modeling. Developments in Earth and Environmental Sciences, v.7, p.235-266, 2007.

GOSWAMI, R.K.; MAHANTA, C. Leaching characteristics of residual lateritic soils stabilized with fly ash and lime for geotechnical applications. Waste Management, v.27, p. 466-481, 2007. 
HAMON, R.; McLAUGHLIN, M.; LOMBI, E. (Editores). Natural attenuation of trace element availability in soils. Boca Raton: CRC Press, 2007.

HANNA, K.; LASSABATERE, L.; BECHET, B. Zinc and lead transfer in a contaminated readside soil: Experimental study and modeling. Journal of Hazardous Materials, v.161, p.1499-1505, 2009.

HATLEY, W.; EDWARDS, R.; LEPP, W.N. Arsenic and heavy metal mobility in iron oxide-amended contaminated soil as evaluated by short- and long-term leaching tests. Environmental Pollution, v.131, p.495-504, 2004.

HE, M.K.; AMERICO, A.I.; GERMANO, T.F. Effect of sulfate on the release rate of $A \AA^{3+}$ from gibbsite. Environmental Science Technology, v.14, n.3, p.1830-1837, 1996.

HEM, J.D. Study and interpretation of the chemical charascteristics of natural water. 3를 Ed. USGS Supply Paper, 1985.

HLAVAY, J.; PROHASKA, T.; WEISZ, M.; WENZEL, W.W.; STINGEDER, G. Determination of trace elements bound to soils and sediment fractions. Pure Applied Chemistry, v.76, n. 2, p. 415-422, 2004.

HÖHN, R.; ISENBECK-SCHRÖTER, M.; KENT, D.B.; DAVIS, J.A.; JAKOBSEN, R.; JANN, S.; NIEDAN, V.; SCHOLZ, C.; STADLER, S.; TRETNER, A. Tracer test with $A s(V)$ under variable redox conditions controlling arsenic transport in the presence of elevated ferrous iron concentrations. Journal of Contaminant Hydrology, v.88, p. 36-54, 2006.

HOLM, P.E.; ANDERSEN, S.; CHRISTENSEN, T.H. Speciation of dissolved cadmium: interpretation of dialysis, ion exchange and computer (GEOCHEM) methods. Water Research, v.29, p. 803-809, 1995.

HUGHES, M.F. Arsenic toxicity and potential mechanisms of action. Toxicology Letters, v.133, p. 1-16, 2002. 
ILGEN, A.G.; RYCHAGOV, S.N.; TRAINOR, T.P. Arsenic speciation and transport associated with the release of spend geothermal fluids in Mutnovsky field (Kamchatka, Russia). Chemical Geology, v.288, p. 115-132, 2011.

ISKANDAR, I.K.; KIRKHAN. M.B (Editores). Trace elements in soil: bioavailability, flux, and transfer. Boca Raton - CRC PRESS LLC, 2001.

IZIDORO, J.C. Estudos sobre a remoção de íons metálicos em água usando zeólitas sintetizadas a partir de cinzas de carvão. Dissertação (Mestrado) Instituto de Pesquisas Energéticas e Nucleares - IPEN/CNEN, São Paulo, 2008.

IZQUIERDO, M.; QUEROL, X. Leaching behaviour of elements from coal combustion fly ash: An overview. International Journal of Coal Geology, v.94, p.54-66, 2012.

JEGADEESAN, G.; AL-ABED, S.R.; PINTO, P. Influence of trace metal distribution on its leachability from coal fly ash. FUEL, v.87, p.1887-1893.

KÄMPF, N.; SCHWERTMANN, U. Relações entre óxidos de ferro e a cor em solos cauliníticos do Rio Grande do Sul. Revista Brasileira de Ciência do Solo, v.7, p. 27-31, 1983.

KASHIWAKURA, S.; OHNO, H.; MATSUBAE-YOKOYAMA, K.; KUMAGAI, Y.; KUBO, H.; NAGASAKA, T. Removal of arsenic in coal fly ash by acid washing process using dilute $\mathrm{H}_{2} \mathrm{SO}_{4}$ solvent. Journal of Hazardous Materials, v. 181, n.13, p. 419-425, 2010.

KENG, J.C.W.; UEHARA, G. Chemistry, mineralogy and taxonomy of Oxisols and Ultisols. Proceedings of Soil Crop Science Society of Florida, v.33, p. 119-126, 1974.

KRISHNAMURTI, G.S.R.; NAIDU, R. Solid-solution equilibria of cadmium in soils. Geoderma, v. 113, p. 17-30, 2003.

LAMBRECHTS, T.; GUSTOT, Q.; COUDER, E.; HOUBE, D.; ISERENTANT, A.; LUTTS, S. Comparison of EDTA-enhanced phytoextraction and phytostabilisation 
strategies with Lolium perenne on a heavy metal contaminated soil. Chemosphere, v.85, p. 1290-1298, 2011.

LEPSCH, I.F. Formação e conservação dos solos. Oficina de Textos, São Paulo, 2002.

LEVANDOWSKI, J.; KALKREUTH, W. Chemical and petrographical characterization of feed coal, fly ash and bottom ash from the Figueira Plant, Paraná, Brazil. International Journal of Coal Geology, v.77, n. 3-4, p.269-281, 2009

LIANG, J.; XU, R.; JIANG, X.; WANG, Y.; ZHAO, A.; TAN, W. Effect of arsenate on adsorpion of Cd (II) by two variable charge soils. Chemosphere, v.67, p.19491955, 2007.

LIBARDI, P.L. Dinâmica da água no solo. Edusp, São Paulo, 2005.

LUMSDON, D.G.; MEEUSSEN, J.C.L.; PATERSON, E.; GARDEN, L.M.; ANDERSON, P. Use of solid phase characterization and chemical modeling for assessing the behavior of arsenic in contaminated soils. Applied Geochemistry, v.16, p. 571-581, 2001.

LUTHER, S.; BORGFELD, N.; KIM, J.; PARSONS, J.G. Removal of arsenic from aqueous solution: $A$ study of the effects of $\mathrm{pH}$ interfering ions using iron oxide nanomaterials. Microchemical Journal, v.101, p. 30-36, 2012.

MANAHAN, S.E. Environmental Chemistry. 6a Ed. Boca Raton, CRC Press Inc, 2000.

MARTINEZ, C.E.; JACOBSON, A.R.; McBRIDE, M.B. Aging and temperature effects on DOC and elemental release from a metal contaminated soil. Environmental Pollution, v.122, n.1, p. 135-153.

MCBRIDE, M.B. Environmental Chemistry of Soils. Oxford University Press, New York, 1994. 
MEKARU, T.; UEHARA, G. Anion adsorption in ferrugineous tropical soils. Soil Science Society of America Proceedings, v. 36 (2), p.296-300, 1972.

MELFI, A.J.; MONTES, C.R.; CARVALHO, A.; FORTI, M.C. Use of pedological maps in the identification of sensitivity of soils to acidic deposition: Application to Brazilian Soils. Anais da Academia Brasileira de Ciências, v.76 (1), p.139-145, 2004.

MELO, V.F.; ALLEONI, L.R.F (Editores). Química e Mineralogia de Solos. SBCS, Viçosa, 2009.

MILLIOLI, V.S. Avaliação da potencialidade da utilização de surfactantes na biorremediação de solo contaminado com hidrocarbonetos de petróleo. Tese (Doutorado). Universidade Federal do Rio de Janeiro, Escola de Química, Rio de Janeiro, 2009.

MOHAN, D.; PITTMAN JUNIOR, C.U. Arsenic removal from water/wastewater using absorbents - A critical review. Journal of Hazardous Materials, v. 142, p. 1-53, 2007.

NOGUEIROL, R.C. Extração seqüencial e especiação de metais pesados e emissão de gases de efeito estufa em Neossolo Litólico contaminado com resíduo rico em $\mathrm{Ba}, \mathrm{Cu}, \mathrm{Ni}, \mathrm{Pb}$ e $\mathrm{Zn}$. Dissertação (mestrado). Escola Superior de Agricultura Luiz Queiroz - USP, Piracicaba, São Paulo, 2008.

ORGANIZAÇÕES DAS NAÇÕES UNIDAS - ONU - disponível em http://www.pnud.org.br/idh/, acessado em 12/06/2011.

PARKHURST, D.L. User's guide to PHREEQC, a computer model for speciation, reaction path, advective transport and inverse geochemical calculations. U.S. Geological Survey, 1995.

PIERZYNSKI, G.M; SIMS, J.T; VANCE, G.F. Soils and Environmental Quality. Boca Raton, CRC Press Inc, 1994.

PINTO, C.S. Curso Básico de Mecânica dos Solos. $1^{\text {a }}$ Ed. São Paulo, Oficina de Textos, v. 1, 2000. 
PIRES, M.; QUEROL, X. Characterization of Candiota (South Brazil) coal and combustion by-products. International Journal of Coal Geology, v. 60, n. 1, p. 57-72, 2004.

PROKOP, Z.; CUPR, P.; ZLEVOROVA-ZLAMALIKOVA, V.; DUSEK, L.; HOLOUBEK, I. Mobility, bioavailability, and toxic effects of cádmium in soil samples. Environmental Research, v.91, p. 119-126, 2003.

QUAGGIO, J. A. Acidez e calagem em solos tropicais. Instituto Agronômico de Campinas, Campinas, 2000.

QUEROL, X.; UMAÑA, J.C.; ALASTUEY, A.; AYORA, C.; LOPEZ-SOLER, A.; PLANA, F. Extraction of soluble major and trace elements from fly ash in open and closed leaching systems. Fuel, v. 80, p. 801-813, 2001.

RAIJ, B.V.; ANDRADE, J.C. de; CANTARELLA, H.; QUAGGIO, J.A. Análise química para avaliação de fertilidade de solos tropicais. Campinas, Instituto Agronômico, 2001.

REIMANN, C.; CARITAT, P. de. Chemical elements in the environment. Berlin, Springer, 1988.

RESENDE, M.; SANTANA, D.P. Uso das relações $\mathrm{Ki}$ e $\mathrm{Kr}$ na estimativa da mineralogia para classificação dos latossolos. Reunião de Classificação, Correlação dos Solos e Interpretação da Aptidão Agrícola (Embrapa, Ed.). Rio de Janeiro: Empresa Brasileira de Agropecuária, Centro Nacional de Pesquisa de Solos, p. 225-232,1998.

RESENDE, M.; CURI, N.; RESENDE, S.B.; CORRÊA, G.F. Pedologia - Base para distinção de ambientes. NEPUT, Viçosa, 2002.

ROCHA, F. R.; SILVA, J. A. F.; LAGO, C. L.; FORNARO, A.; GUTZ, I. G. R. Wet deposition and related atmospheric chemistry in the São Paulo Metropolis, Brazil: Part 1. Major inorganic ions in rainwater as evaluated by capillary electrophoresis with contactless conductivity detection. Atmospheric Environment, v.37, n. 1, p.105-115, 2003. 
ROHDE, G.M.; ZWONOK, O.; CHIES, F.; SILVA, N.I.W. Cinzas de Carvão Fóssil no Brasil. CIENTEC, Porto Alegre, 2006.

SANDRONI, V., SMITH, C.M.M. Microwave digestion: of sludge, soil and sediment samples for metal analysis by inductively coupled plasma-atomic emission spectrometry. Analytica Chimica Acta, v.468, p. 335-344, 2002.

SAYYAD, G.; AFYUNI, M.; MOUSAVI, S.F.; ABBASPOUR, K.C.; RICHARDS, B.K; SCHULIN, R. Transport of $\mathrm{Cd}, \mathrm{Cu}, \mathrm{Pb}$ and $\mathrm{Zn}$ in a calcareous soil under wheat und safflower cultivation - A column study. Geoderma, v. 154, p.311-320, 2010.

SCHWERTMANN, U.; KODAMA, H.; FISCHER, W.R. Mutual interactions between organic and iron oxides. In: HUANG, P.M.; SCHNITZER, M. (Ed.). Interactions of soil mineral with natural organics and microbes. Soil Science Society of America Special Publication, n. 17, p. 223-250, 1986.

SELIM, H.M.; SPARKS, D.L. (Editores). Heavy metals release in soils. Boca Raton, CRC Press LLC, 2001.

SIEGEL, F.R. Environmental geochemistry of potentially toxic metals. Berlin, Springer, 2002.

SKOOG, D.A.; NIEMAN, T.A.; HOLLER, F.J. 5a Ed. Princípios de análise instrumental. São Paulo, Artmed, 2002.

SOARES, M.R. Coeficiente de distribuição $\left(K_{D}\right)$ de metais pesados em solos do estado de São Paulo. Tese (Doutorado). Escola Superior de Agricultura Luiz Queiroz - USP, Piracicaba, São Paulo, 2004.

SPARKS, D.L. Environmental Soil Chemistry. Califórnia, Academic Press, 2003. SPOSITO, G. The Chemistry of soils. New York, Oxford University Press, 1989.

STEPHAN, C.H.; COURCHESNE, F.; HENDERSHOT, W.H.; McGRATH, S.P.; CHAUDRI, A.M.; SAPPIN-DIDIER, V.; SAUVÉ, S. Speciation of zinc in contaminated soils. Environmental Pollution, n.155, p. 208-216, 2008. 
TEXEIRA, R. Caracterização e avaliação da contaminação do solo laterítica da área do depósito de resíduos sólidos urbanos de Londrina por metais pesados. Tese (doutorado). Universidade Federal de Santa Catarina - UFSC, Florianópolis, 2008.

TEXEIRA, W.; FAIRCHILD, T.R.; TOLEDO, M.C.M.; TAIOLI, F. Decifrando a Terra. $2^{\mathrm{a} e d . ~ S a ̃ o ~ P a u l o, ~ C o m p a n h i a ~ E d i t o r a ~ N a c i o n a l, ~} 2009$.

TRETNER, A. Sorptios- und Redoxprozesse von Arsen na oxidishen Oberflächen - Experimentelle Untersuchungen. Dissertação (diploma). Heidelberg Universität, Heidelberg, 2002.

URE, A.M. Single extraction schemes for soil analysis and related applications. Science of the Total Environment, v. 178, p. 3-10, 1996.

UNITED STATES ENVIRONMETAL PROTECTION AGENCY, USEPA. Method 3051 A. 1998b. Disponível em: http://www.epa.gov/SW-846/3051a.pdf. Acesso em: 02-Mai-2011.

VOGLAR, D.; LESTAN, D. Pilot-scale washing of metal contaminated garden soil using EDTA. Journal of Hazardous Materials, v. 215-216, p. 32-39, 2012.

WANG, S.; MULLIGAN, C.N. Enhanced mobilization of arsenic and heavy metals from mine tailings by humic acid. Chemosphere, v.74, p.274-279, 2009.

WARD, C.R.; FRENCH, D.; JANKOWSKI, J.; DUBIKOVA, M.; LI, Z.; RILEY, K.W. Element mobility from fresh and long-stored acidic fly ashes associated with an Australian power station. International Journal Coal Geology, v. 80, p. 224-236, 2009.

World Coal Institute, WCI - disponível em: http://www.worldcoal.org/resources/coal-statistics, acessado 03/06/2011.

XIA, W.; GAO, H.; WANG, X.; ZHOU, C.; LIU, Y.; FAN, T.; WANG, X. Application of EDTA decontamination on soils affected by mining activities and impact of treatment on the geochemical partition of metal contaminants. Journal of Hazardous Materials, v.164, p. 936-940, 2009. 
YONG, R. N.; MULLIGAN, C.N. Natural attenuation of contaminants in soil. Boca Raton, CRC Press LLC, 2004.

YUE, Z.; DONAHOE, R.J. Experimental simulation of soil contamination by arsenolite. Applied Geochemistry, v.24, p. 650-656, 2009.

ZHU, R.; WU, M.; YANG, J. Mobilities and leachabilities of heavy metals in sludge with humus soil. Journal of Environmental Sciences, v. 23, n. 2, p. 247-254, 2011.

ZHU, C.; ANDERSON, G. Environmental applications of geochemical modeling. Cambridge, Cambridge University Press, 2002. 


\section{APÊNDICE 1}

TABELA 1-A - Concentração parcial dos elementos majoritários nas amostras de cinza

\begin{tabular}{|c|c|c|c|c|c|c|c|c|c|}
\hline \multirow{4}{*}{ Elemento } & \multirow{2}{*}{\multicolumn{3}{|c|}{$\begin{array}{c}\text { Cinza } \\
\text { Não lixiviada } \\
\left(\mathrm{mg} \mathrm{kg}^{-1}\right)\end{array}$}} & \multicolumn{6}{|c|}{ Cinza lixiviada $\left(\mathrm{mg} \mathrm{kg}^{-1}\right)$} \\
\hline & & & & Co & nas de & & Colun & de cin & tsolo \\
\hline & \multirow{2}{*}{ Média } & \multicolumn{2}{|c|}{ Intervalo } & \multirow{2}{*}{ Média } & \multicolumn{2}{|c|}{ Intervalo } & \multirow{2}{*}{ Média } & \multicolumn{2}{|c|}{ Intervalo } \\
\hline & & Máx & Mín & & Máx & Mín & & Máx & Mín \\
\hline Al & 8535 & 8660 & 8410 & 8683 & 9339 & 8026 & 8658 & 9920 & 5780 \\
\hline $\mathrm{Fe}$ & 26500 & 26800 & 26100 & 27000 & 28300 & 23500 & 27913 & 31100 & 20500 \\
\hline Mn & 161 & 162 & 160 & 157 & 164 & 150 & 128 & 142 & 97 \\
\hline $\mathrm{Na}$ & 1115 & 1140 & 1090 & 621 & 670 & 502 & 949 & 1110 & 658 \\
\hline Mg & 914 & 926 & 901 & 833 & 886 & 745 & 796 & 927 & 539 \\
\hline Si & 37 & 38 & 36 & 39 & 44 & 34 & 33 & 45 & 25 \\
\hline $\mathrm{K}$ & 2710 & 2740 & 2680 & 2503 & 2710 & 2150 & 2545 & 3000 & 1680 \\
\hline $\mathrm{Ca}$ & 3750 & 3810 & 3690 & 1468 & 1600 & 1310 & 1509 & 1740 & 1140 \\
\hline
\end{tabular}

TABELA 2-A - Concentração parcial dos elementos majoritários nas amostras de solo

\begin{tabular}{|c|c|c|c|c|c|c|c|c|c|}
\hline \multirow{4}{*}{ Elemento } & \multirow{2}{*}{\multicolumn{3}{|c|}{$\begin{array}{c}\text { Solo } \\
\text { Não lixiviado } \\
\left(\mathbf{m g ~ k g ~}^{-1}\right)\end{array}$}} & \multicolumn{6}{|c|}{ Solo Lixiviado $\left(\mathrm{mg} \mathrm{kg}^{-1}\right)$} \\
\hline & & & & \multicolumn{3}{|c|}{ Colunas de solo } & \multicolumn{3}{|c|}{ Colunas de solo+cinza } \\
\hline & \multirow{2}{*}{ Média } & \multicolumn{2}{|c|}{ Intervalo } & \multirow{2}{*}{ Média } & \multicolumn{2}{|c|}{ Intervalo } & \multirow{2}{*}{ Média } & \multicolumn{2}{|c|}{ Intervalo } \\
\hline & & Máx & Mín & & Máx & Mín & & Máx & Mín \\
\hline Al & 41150 & 67800 & 14500 & 18338 & 21680 & 14500 & 18300 & 20900 & 14700 \\
\hline $\mathrm{Fe}$ & 9985 & 10300 & 9670 & 11025 & 11500 & 10300 & 10637 & 11400 & 9800 \\
\hline Mn & 22 & 23 & 20 & 25 & 29 & 22 & 24 & 30 & 20 \\
\hline $\mathrm{Na}$ & 316 & 364 & 268 & 327 & 365 & 277 & 320 & 350 & 242 \\
\hline Mg & 103 & 113 & 92 & 117 & 139 & 95 & 123 & 135 & 108 \\
\hline Si & 461 & 463 & 458 & 396 & 497 & 207 & 122 & 175 & 75 \\
\hline $\mathbf{K}$ & 166 & 192 & 140 & 160 & 218 & 110 & 162 & 197 & 111 \\
\hline $\mathrm{Ca}$ & 266 & 277 & 255 & 266 & 308 & 216 & 457 & 488 & 376 \\
\hline
\end{tabular}


